\title{
Site Characterization Data from the U3ax/bl Exploratory Boreholes at the Nevada Test Site
}

\author{
Prepared by \\ Bechtel Nevada \\ Geotechnical Sciences \\ Las Vegas, Nevada \\ Prepared for \\ U.S. Department of Energy \\ National Nuclear Security Administration \\ Nevada Site Office \\ Las Vegas, Nevada
}

August 2005 


\title{
DISCLAIMER STATEMENT
}

Reference herein to any specific commercial product, process, or service by trade name, trademark, manufacturer, or otherwise, does not necessarily constitute or imply its endorsement, recommendation, or favoring by the U.S. Government or any agency thereof. The views and opinions of authors expressed herein do not necessarily state or reflect those of the U.S. Government or any agency thereof

\section{AVAILABILITY STATEMENT}

Available for sale to the public from-

\author{
U.S. Department of Commerce \\ National Technical Information Service \\ 5285 Port Royal Road \\ Springfield, VA, 22161-0002 \\ Telephone: 800.553.6847 \\ Fax: 703.605.6900 \\ E-mail: orders@ntis.gov \\ Online ordering: http://www.ntis.gov/ordering.htm
}

Available electronically at http://www.osti.gov/bridge.

Available for a processing fee to U.S. Department of Energy and its contractors, in paper, from-

U.S. Department of Energy

Office of Scientific and Technical Information

P.O. Box 62

Oak Ridge, TN 37831-0062

Telephone: 865.576.8401

Fax: 865.576.5728

E-mail: reports@adonis.osti.gov 


\title{
Site Characterization Data from the U3ax/bl Exploratory Boreholes at the Nevada Test Site
}

\author{
Prepared by \\ Bechtel Nevada \\ Geotechnical Sciences \\ Las Vegas, Nevada \\ Prepared for \\ U.S. Department of Energy \\ National Nuclear Security Administration \\ Nevada Site Office \\ Las Vegas, Nevada
}

August 2005

This manuscript was prepared by Bechtel Nevada under Contract No. DE-AC08-96NV11718 with the U.S. Department of Energy. 
This page intentionally left blank. 


\title{
Site Characterization Data from the U3ax/bl Exploratory Boreholes at the Nevada Test Site
}

\author{
DOE/NV/11718--003-REV.1
}

\begin{abstract}
Preface
The Special Projects Section of Reynolds Electrical \& Engineering Co., Inc. (REECo) and its successor, Bechtel Nevada (BN), were responsible for characterizing the subsurface hydrogeology of the Area 3 Radioactive Waste Management Site (RWMS) at the Nevada Test Site for the U.S. Department of Energy, Nevada Operations Office in the early and mid-1990s. This work was documented in a series of limited-distribution data reports. As part of BN's current scope for closure planning for the Area 3 RWMS, some of these REECo and older BN data reports are being updated and submitted for approval for public release so they will be accessible for public review and for citation in future documents.
\end{abstract}

This document was originally prepared under the same title in April 1996, by John S. Schmeltzer, Lawrence E. Barker, and Daniel O. Blout. The report has been updated by revising it to conform to current editorial standards of BN and of the U.S. Department of Energy, National Nuclear Security Administration Nevada Site Office.

\section{Acknowledgments}

In the acknowledge section of the original document, the authors expressed their thanks to Ken D. Donnelson of Raytheon Services Nevada, who was the field geologist during drilling of the U3ax/bl boreholes. Mr. Donnelson played a major role in the project. He collected most of the geologic samples, measured the water content of drill cuttings, and completed the borehole log sheets found in Appendix B. Without his assistance the original data report could not have been completed. 
This page intentionally left blank. 


\title{
Site Characterization Data from the U3ax/bl Exploratory Boreholes at the Nevada Test Site
}

\author{
DOE/NV/11718--003-REV.1
}

\begin{abstract}
This report provides qualitative analyses and preliminary interpretations of hydrogeologic data obtained from two 45-degree, slanted exploratory boreholes drilled within the Area 3 Radioactive Waste Management Site (RWMS) at the Nevada Test Site. Borehole UE-3bl-D1 was drilled beneath the U3ax/bl mixed waste disposal unit, and Borehole UE-3bl-U1 was drilled in undisturbed alluvium adjacent to the disposal unit. The U3ax/bl disposal unit is located within two conjoined subsidence craters, U3ax and U3bl, which were created by underground nuclear testing. Data from these boreholes were collected to support site characterization activities for the U3ax/bl disposal unit and the entire Area 3 RWMS. Site characterization at disposal units within the Area 3 RWMS must address the possibility that subsidence craters and associated disturbed alluvium of the chimneys beneath the craters might serve as pathways for contaminant migration.
\end{abstract}

The two boreholes were drilled and sampled to compare hydrogeologic properties of alluvium below the waste disposal unit with those of adjacent undisturbed alluvium. Whether Borehole UE-3bl-D1 actually penetrated the chimney of the U3bl crater is uncertain. Analyses of core samples showed little difference in hydrogeologic properties between the two boreholes.

Important findings of this study include the following:

- No hazardous or radioactive constituents of waste disposal concern were found in the samples obtained from either borehole.

- No significant differences in physical and hydrogeologic properties between boreholes is evident, and no evidence of significant trends with depth for any of these properties was observed. The values observed are typical of sandy materials.

- The alluvium is dry, with volumetric water content ranging from 5.6 to 16.2 percent. Both boreholes exhibit a slight increase in water content with depth, the only such trend observed.

- Water potential measurements on core samples from both boreholes show a large positive potential gradient (water moves upward, via evapotranspiration) for the entire vertical depth.

- Very little liquid flow occurs through the vadose zone. The direction of flow in the upper vadose zone (approximately the upper 35 meters) is upward, based on unsaturated hydraulic conductivity data, water potential data, and environmental tracer data. 
This page intentionally left blank. 


\section{Table of Contents}

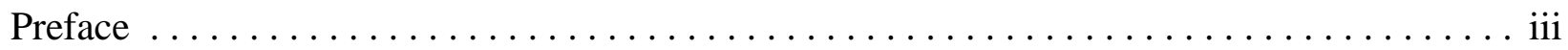

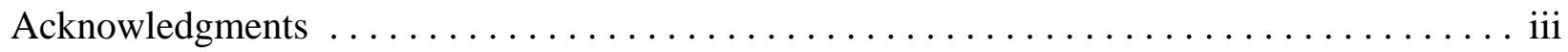

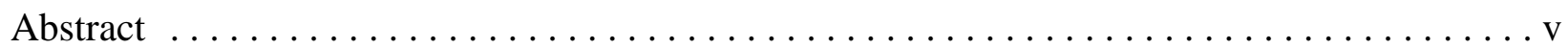

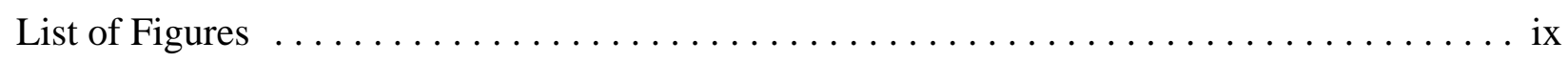

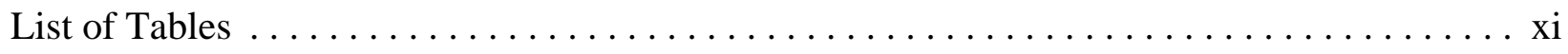

List of Appendices $\ldots \ldots \ldots \ldots \ldots \ldots \ldots \ldots \ldots \ldots \ldots \ldots \ldots \ldots \ldots \ldots \ldots \ldots \ldots \ldots$

List of Acronyms and Abbreviations $\ldots \ldots \ldots \ldots \ldots \ldots \ldots \ldots \ldots \ldots \ldots \ldots \ldots \ldots \ldots \ldots \ldots$

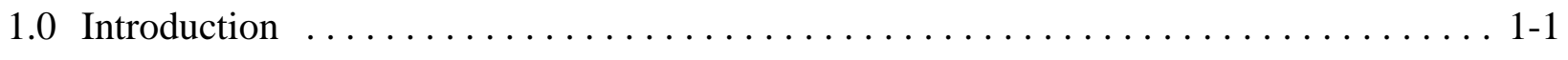

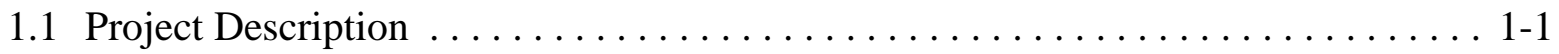

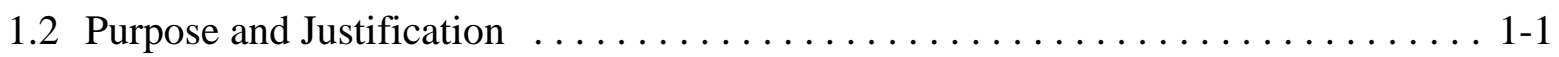

1.3 Data Objectives of the Drilling Project $\ldots \ldots \ldots \ldots \ldots \ldots \ldots \ldots \ldots \ldots \ldots \ldots \ldots \ldots$

1.4 Scope of Report . . . . . . . . . . . . . . . . . . . . . . 1-4

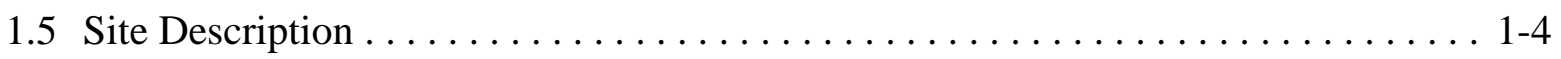

1.6 Testing and Waste Management Activities $\ldots \ldots \ldots \ldots \ldots \ldots \ldots \ldots \ldots \ldots$

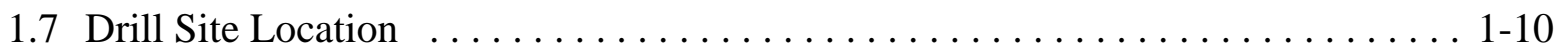

2.0 Drilling, Sampling, and Completion $\ldots \ldots \ldots \ldots \ldots \ldots \ldots \ldots \ldots \ldots \ldots \ldots \ldots \ldots$

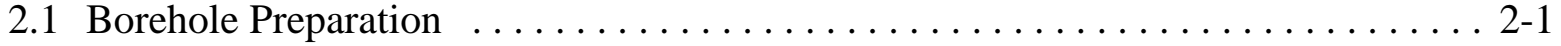

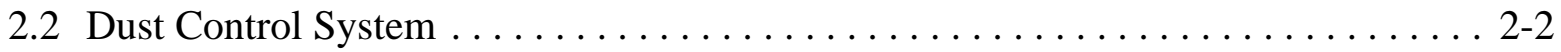

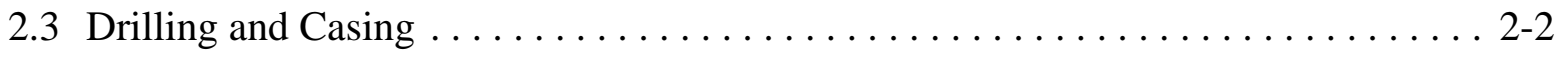

2.4 Sampling for Hydrogeologic and Environmental Tracer Data . . . . . . . . . . 2-3

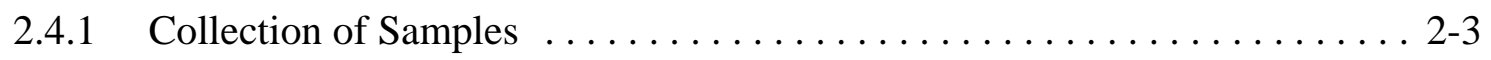

2.4.2 Geologic Description and Storage of Samples ... . . . . . . . . 2-6

2.4.3 Radiological Surveys of Geologic Samples . . . . . . . . . . . . . 2-8

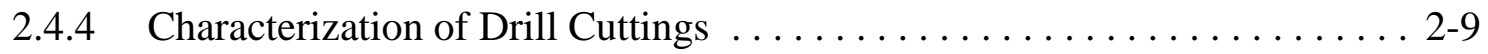

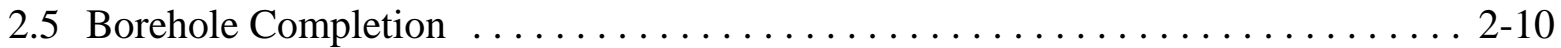

3.0 Laboratory Testing Methods and Results $\ldots \ldots \ldots \ldots \ldots \ldots \ldots \ldots \ldots \ldots \ldots$. . . . . . .

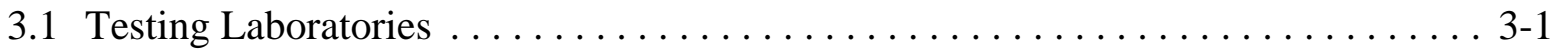

3.2 Laboratory Test Results $\ldots \ldots \ldots \ldots \ldots \ldots \ldots \ldots \ldots \ldots \ldots \ldots \ldots \ldots \ldots \ldots \ldots \ldots$ 
3.3 General Geologic Description, Lithology, and Stratigraphy $\ldots \ldots \ldots \ldots \ldots \ldots$ 3-9

3.3.1 General Geologic, Lithologic, and Stratigraphic Data for Alluvium . . . . . 3-9

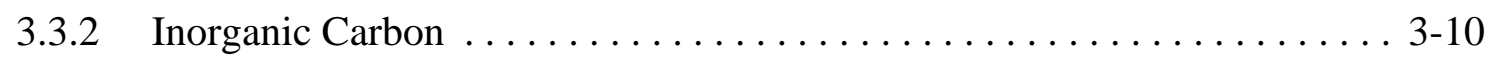

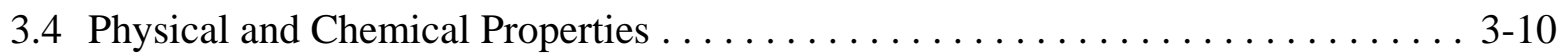

3.4.1 Particle Size Distribution . . . . . . . . . . . . . . . . . . . . . . 3-10

3.4.2 Bulk Density, Particle Density, and Porosity $\ldots \ldots \ldots \ldots \ldots \ldots \ldots$ 3-12

3.4.3 Cation-Exchange Capacity $\ldots \ldots \ldots \ldots \ldots \ldots \ldots \ldots \ldots \ldots \ldots . \ldots \ldots . .17$

3.5 Hydrogeologic Properties . . . . . . . . . . . . . . . . . . . . . . . . . . . 3-22

3.5.1 Saturated Hydraulic Conductivity $\ldots \ldots \ldots \ldots \ldots \ldots \ldots \ldots \ldots \ldots . . \ldots \ldots .22$

3.5.2 Moisture Retention Relations $\ldots \ldots \ldots \ldots \ldots \ldots \ldots \ldots \ldots \ldots \ldots . . .25$

3.5.3 Unsaturated Hydraulic Conductivity . . . . . . . . . . . . . . . . . 3-26

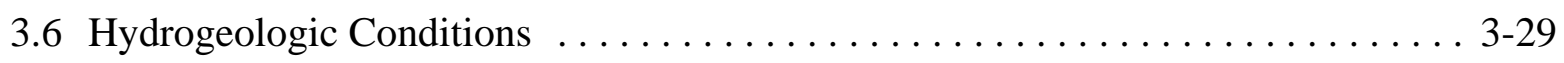

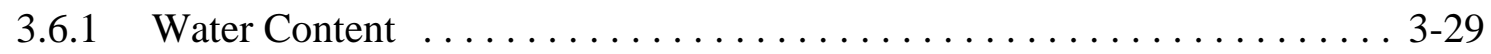

3.6.2 Total Hydraulic Potential . . . . . . . . . . . . . . . . . . . . . 3-30

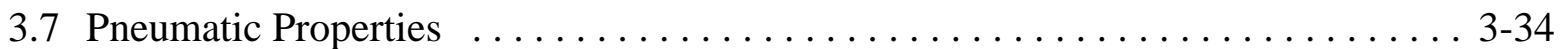

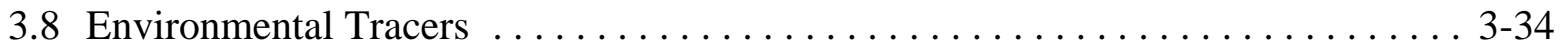

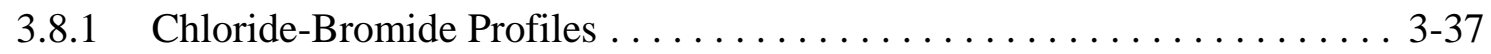

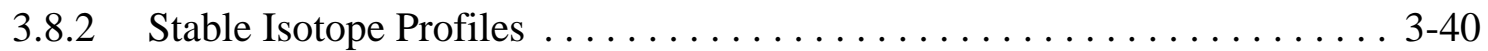

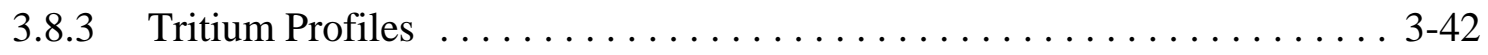

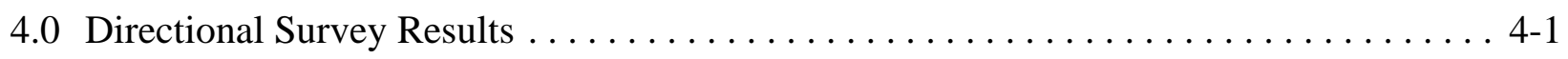

5.0 Recommendations and Future Work $\ldots \ldots \ldots \ldots \ldots \ldots \ldots \ldots \ldots \ldots \ldots \ldots \ldots \ldots \ldots$

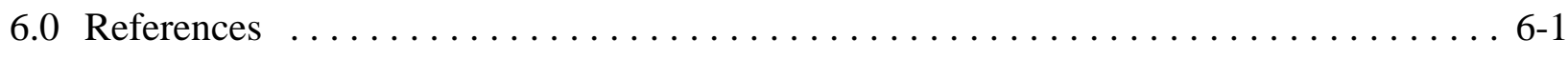

Distribution List 


\section{List of Figures}

Number

Title

Page

1-1 Location of the Area 3 Radioactive Waste Management Site at the

Nevada Test Site . . . . . . . . . . . . . . . . . . . . . . . . . . . . . . . . . 1-2

1-2 Location of the Area 3 Radioactive Waste Management Site in Yucca Flat . . . . . 1-5

1-3 Location of the U3ax/bl Exploratory Boreholes Within the Area 3 Radioactive

Waste Management Site . . . . . . . . . . . . . . . . . . . .

3-1 Slant Depth Profiles of Inorganic Carbon for Core Samples from the U3ax/bl

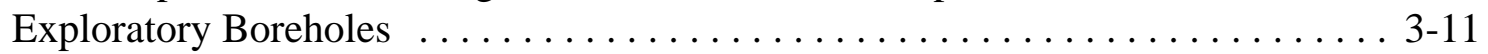

3-2 Slant-Depth Profiles of Dry Sieve Analyses for Core Samples from UE-3bl-D1 . 3-13

3-3 Slant-Depth Profiles of Dry Sieve Analyses for Core Samples from UE-3bl-U1 . . 3-14

3-4 Slant-Depth Profiles of Dry Bulk Density for Core Samples from UE-3bl-D1 . . . 3-15

3-5 Slant-Depth Profiles of Dry Bulk Density for Core Samples from UE-3bl-U1 . . . 3-16

3-6 Slant-Depth Profiles of Dry Bulk Density for DB1 Core Samples from the U3ax/3bl Exploratory Boreholes . . . . . . . . . . . . . . . . . . . . 3-18

3-7 Slant-Depth Profiles of Particle Density for Core Samples from UE-3bl-D1 . . . 3-19

3-8 Slant-Depth Profiles of Calculated (c) and Water-Saturated (s) Porosity for Core Samples from UE-3bl-D1 . . . . . . . . . . . . . . . . . . . . . . . . . . 3-20

3-9 Slant-Depth Profiles of Calculated (c) and Water-Saturated (s) Porosity for

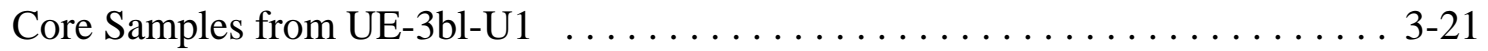

3-10 Slant-Depth Profiles of Cation-Exchange Capacity for Core Samples from the U3ax/3bl Exploratory Boreholes . . . . . . . . . . . . . . . . . 3-23

3-11 Slant-Depth Profiles of Saturated Hydraulic Conductivity for Core Samples from the U3ax/3bl Exploratory Boreholes . . . . . . . . . . . . . . . 3-24

3-12 Composite Moisture Retention Curve Data for Core Samples from UE-3bl-D1 . . . 3-27

3-13 Composite Moisture Retention Curve Data for Core Samples from UE-3bl-U1 . . . 3-27

3-14 Fitted Unsaturated Hydraulic Conductivity Functions For Core Samples from UE-3bl-D1 . . . . . . . . . . . . . . . . . . . . . . 3-28

3-15 Fitted Unsaturated Hydraulic Conductivity Functions For Core Samples from UE-3bl-U1 . . . . . . . . . . . . . . . . . . . . . . . 3-28

3-16 Slant Depth Profiles of Water Content for Core Samples from UE-3bl-D1 . . . . . 3-31

3-17 Slant Depth Profiles of Water Content for Core Samples from UE-3bl-U1 . . . . . 3-32

3-18 Slant Depth Profiles of Volumetric Water Content for DB1 Core Samples from the U3ax/bl Exploratory Boreholes . . . . . . . . . . . . . . 3-33

3-19 Vertical Depth Profiles of Total Hydraulic Potential for Core Samples from the U3ax/3bl Exploratory Boreholes 


\section{List of Figures (Continued)}

Number

Title

Page

3-20 Slant Depth Profiles of Air Permeability for UE-3bl-D1 and Calculated (c) Permeability for Core Samples from the U3ax/3bl Exploratory Boreholes . . . . . . 3-36

3-21 Slant Depth Profiles of Dry Soil Chloride Concentrations for Core Samples from the U3ax/bl Exploratory Boreholes . . . . . . . . . . . . . . . . 3-38

3-22 Slant Depth Profiles of Dry Soil Bromide Concentrations for Core Samples from the U3ax/bl Exploratory Boreholes . . . . . . . . . . . . . . . . . 3-39

3-23 Slant Depth Profiles of Dry Soil Chloride-Bromide Ratios for Core Samples from the U3ax/bl Exploratory Boreholes . . . . . . . . . . . . . . . . . . 3-41

3-24 Slant Depth Profiles of Stable Isotopes for Core Samples from the U3ax/bl Exploratory Boreholes . . . . . . . . . . . . . . . . . . . . 3-43

3-25 Comparison of Measured Stable Isotopes for Core Samples from UE-3bl-D1 with Stable Isotope Data for the Global Meteoric Water Line (MWL) . . . . . . . . 3-43

3-26 Comparison of Measured Stable Isotopes for Core Samples from UE-3bl-U1 with Stable Isotope Data for the Global Meteoric Water Line (MWL) . . . . . . . . 3-45

3-27 Slant Depth Profiles of Unenriched Tritium Concentrations for Geologic Samples from the U3ax/bl Exploratory Boreholes . . . . . . . . . . . . 3-47

4-1 Cross Section Showing UE-3bl-D1 Relative to the Estimated Positions of the U3bl Crater/Chimney/Cavity 


\section{List of Tables}

Number

Title

Page

1-1 Drilling and Location Data for the U3ax/bl Exploratory Boreholes $\ldots . \ldots \ldots \ldots$ 1-10

2-1 REECo Standard Operating Procedures Applicable to the U3ax/bl

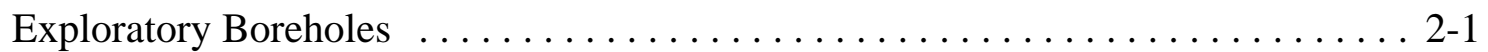

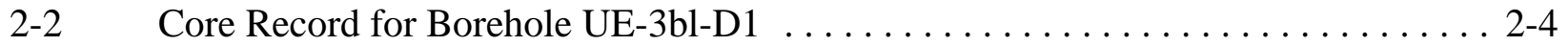

2-3 Core Record for Borehole UE-3bl-U1 $\ldots \ldots \ldots \ldots \ldots \ldots \ldots \ldots \ldots \ldots \ldots \ldots \ldots \ldots$

2-4 Definitions of Core and Drill Cuttings Sample Labels for the U3ax/bl

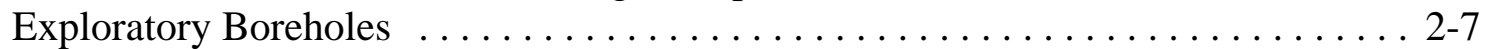

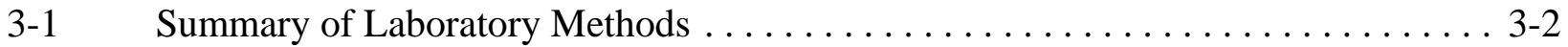

3-2 Summary of the Numbers of Tests Performed on Samples from the U3ax/bl Exploratory Boreholes . . . . . . . . . . . . . . . . . . . . . . . . . . . 3-4

3-3 Summary of Descriptive Statistics for Physical and Pneumatic Properties for Core Samples from the U3ax/bl Exploratory Boreholes ............... 3-5

3-4 Summary of Descriptive Statistics for Hydrologic Properties for Core and Drill Cuttings Samples from the U3ax/bl Exploratory Boreholes ............ 3-6

3-5 Summary of Descriptive Statistics for Chemical Properties and Environmental Tracer Data for Core Samples and Drill Cuttings Samples from the U3ax/bl Exploratory Boreholes . . . . . . . . . . . . . . . . . . . . 3-7

3-6 Summary of Unified Soil Classification System Assignments for Core Samples from the U3ax/bl Exploratory Boreholes . ...................... 3-8

3-7 Summary of Descriptive Statistics of Moisture Retention Curves for Core Samples from the U3ax/bl Exploratory Boreholes . . . . . . . . . . . . . . . 3-8

A-1 Chronological Drilling Summary for Borehole UE-3bl-D1 . . . . . . . . . . . . A-1 


\section{List of Appendices}

A Drilling Information

A.1 Chronological Drilling Summary for UE-3bl-D1

B Core and Drill Cuttings Sample Description Data

B.1 Borehole Log Sheets for UE-3bl-D1

B.2 Borehole Log Sheets for UE-3bl-U1

B.3 Drill Cuttings Log Data for UE-3bl-D1

B.4 Drill Cuttings Log Data for UE-3bl-U1

C Laboratory Testing Data of Geologic Samples

C.1 Results of Laboratory Tests for Hydrogeologic Properties for Core Samples from UE-3bl-D1

C.2 Results of Laboratory Tests for Physical and Pneumatic Properties for Core Samples from UE-3bl-D1

C.3 Results of Laboratory Tests for Chemical Properties and Environmental Tracer Data for Core Samples from UE-3bl-D1

C.4 Results of Gravimetric Water Content Measurements for Drill Cuttings Samples from UE-3bl-D1

C.5 Results of Unenriched Tritium Analysis for Drill Cuttings and Core Samples from UE-3bl-D1

C.6 Results of Laboratory Tests for Hydrogeologic Properties for Core Samples from UE-3bl-U1

C.7 Results of Laboratory Tests for Physical and Pneumatic Properties for Core Samples from UE-3bl-U1

C.8 Results of Laboratory Tests for Chemical Properties and Environmental Tracer Data for Core Samples from UE-3bl-U1

C.9 Results of Gravimetric Water Content Measurements for Drill Cuttings Samples from UE-3bl-U1

C.10 Moisture Retention Data for Core Samples from UE-3bl-D1

C.11 Moisture Retention Data for Core Samples from UE-3bl-U1

C.12 Parameters Required to Calculate Unsaturated Hydraulic Conductivities for Core Samples from the U3ax/bl Exploratory Boreholes

C.13 Results of Unenriched Tritium Analysis for Core Samples from UE-3bl-U1 


\section{List of Appendices (Continued)}

D Directional Survey Data

D.1 Gyroscopic Directional Survey by Minimum Curvature for UE-3bl-D1 on August 23, 1994

D.1 Gyroscopic Directional Survey by Minimum Curvature for UE-3bl-U1 on August 23, 1994 


\section{List of Acronyms and Abbreviations}

\begin{tabular}{|c|c|}
\hline${ }^{0} \mathrm{C}$ & degrees Celsius \\
\hline${ }^{0} \mathrm{~F}$ & degrees Fahrenheit \\
\hline${ }^{16} \mathrm{O}$ & oxygen-16 \\
\hline${ }^{18} \mathrm{O}$ & oxygen-18 \\
\hline ASD & Analytical Services Department \\
\hline $\mathrm{BN}$ & Bechtel Nevada \\
\hline CAU & casing-advance under-reaming \\
\hline CEC & cation-exchange capacity \\
\hline CFR & Code of Federal Regulations \\
\hline $\mathrm{cm}$ & centimeter \\
\hline $\mathrm{D}$ & deuterium \\
\hline DBS\&A & Daniel B. Stevens \& Associates,Inc. \\
\hline DOE & U.S. Department of Energy \\
\hline DRI & Desert Research Institute \\
\hline $\mathrm{ft}$ & foot (feet) \\
\hline gal & gallon(s) \\
\hline HGC & Hydro Geo Chem, Inc. \\
\hline I.D. & inner diameter \\
\hline in. & inch(es) \\
\hline $\mathrm{L}$ & liter(s) \\
\hline $\mathrm{m} / \mathrm{hr}$ & meters per hour \\
\hline $\mathrm{m} / \mathrm{s}$ & meters per second \\
\hline $\mathrm{m}^{2}$ & square meter(s) \\
\hline $\mathrm{m}^{3}$ & cubic meter(s) \\
\hline $\mathrm{mi} / \mathrm{hr}$ & miles per hour \\
\hline $\mathrm{mm}$ & millimeter(s) \\
\hline MWL & meteoric water line \\
\hline NNSA/NSO & National Nuclear Security Administration Nevada Site Office \\
\hline NTS & Nevada Test Site \\
\hline O.D. & outside diameter \\
\hline $\mathrm{pCi} / \mathrm{L}$ & picoCuries per liter \\
\hline${ }^{239+240} \mathrm{Pu}$ & plutonium-239 and plutonium-240 \\
\hline QA & Quality Assurance \\
\hline RCRA & Resource Conservation and Recovery Act \\
\hline RCT & Radiological Control Technician \\
\hline REECo & Reynolds Electrical and Engineering Co., Inc. \\
\hline RWMS & Radioactive Waste Management Site \\
\hline SPS & Special Projects Section \\
\hline USCS & Unified Soil Classification System \\
\hline VOCs & volatile organic compounds \\
\hline $\mathrm{yd}^{3}$ & cubic yard(s) \\
\hline
\end{tabular}




\subsection{Introduction}

The work described in this document was conducted by personnel of the Special Projects Section (SPS) of Reynolds Electrical and Engineering Co., Inc. (REECo) and Bechtel Nevada (BN) at the Nevada Test Site (NTS). The work was conducted for the U.S. Department of Energy, National Nuclear Security Administration Nevada Site Office (NNSA/NSO; formerly U.S. Department of Energy [DOE], Nevada Operations Office) Waste Management Division. This report was originally prepared under the same title by John S. Schmeltzer, Lawrence E. Barker, and Daniel O. Blout in April 1996. The original report has been updated to conform to current editorial standards of BN and the NNSA/NSO, and to facilitate public distribution of the data contained herein. The data appendices are included unchanged from the original report. No new data have been added to this report, though additional relevant studies of the area have been conducted in the intervening years.

\subsection{Project Description}

This report provides qualitative analyses and preliminary interpretations of hydrogeologic data obtained from two boreholes drilled at a 45-degree angle from vertical within the NTS Area 3 Radioactive Waste Management Site (RWMS). Borehole UE-3bl-D1 was drilled beneath the U3ax/bl mixed waste (low level radioactive waste containing hazardous constituents) disposal unit to a slant depth of 74 meters (m) (242 feet [ft]). Borehole UE-3bl-U1 was drilled adjacent to the disposal unit to a slant depth of $76 \mathrm{~m}$ (250 ft). The vertically corrected depth for both boreholes is approximately $50 \mathrm{~m}$ (165 ft). Data from these boreholes were collected to support site characterization activities for the U3ax/bl disposal unit and the entire Area 3 RWMS. Figure 1-1 shows the location of the Area 3 RWMS within the NTS. Throughout this report, boreholes UE-3bl-D1 and UE-3bl-U1 will be referred to as boreholes D1 and U1, respectively.

\subsection{Purpose and Justification}

The U3ax/bl disposal unit is regulated under the Resource Conservation and Recovery Act (RCRA), according to Title 40 Code of Federal Regulations (CFR) §265. The disposal unit is located within two conjoined subsidence craters, U3ax and U3bl, which were created by underground nuclear testing. The NNSA/NSO has slated the U3ax/bl disposal unit for permanent closure without groundwater monitoring. Under Title 40 CFR §265, site characterization is required to support the final closure design and groundwater monitoring 


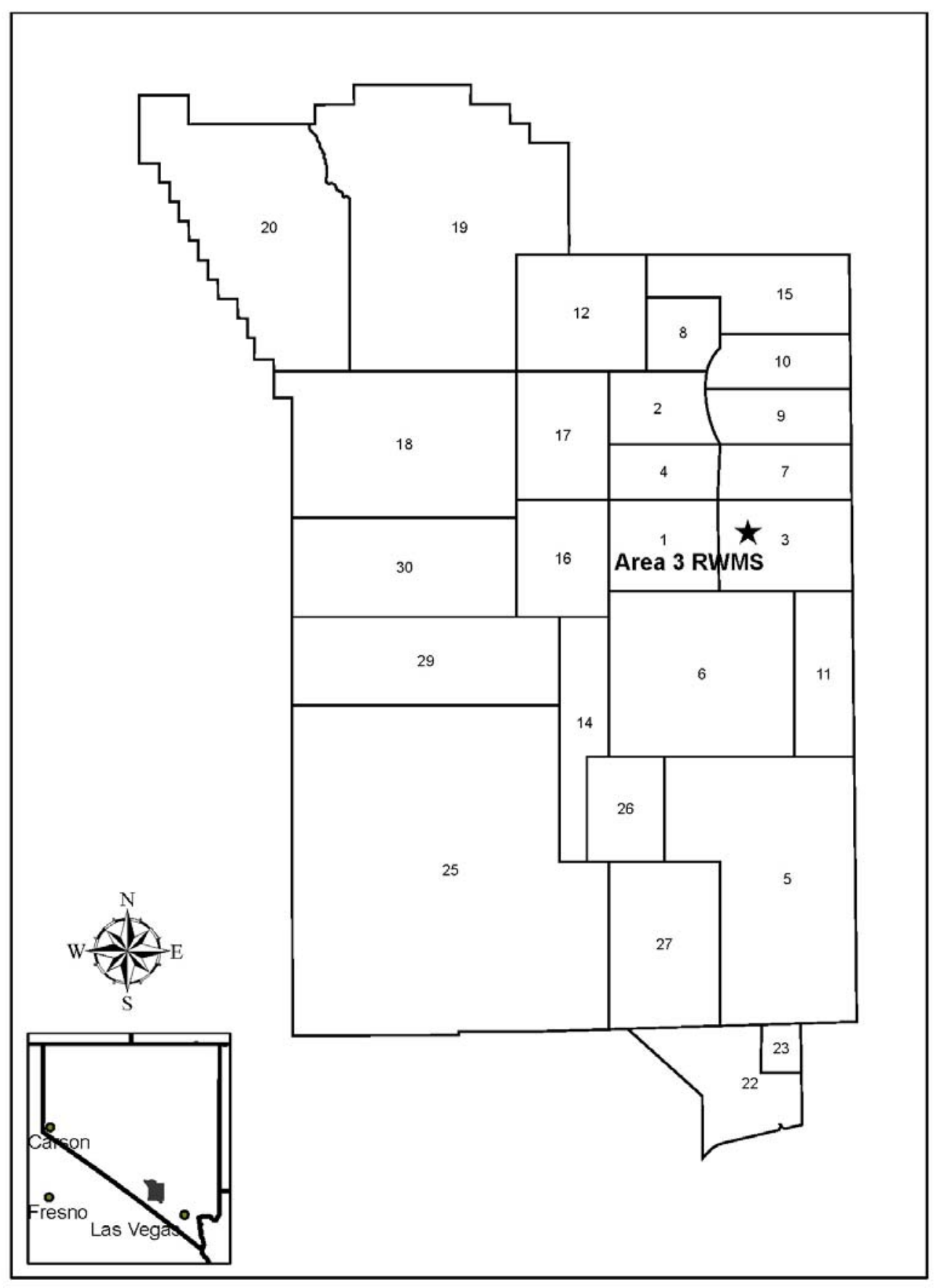

Figure 1-1

Location of the Area 3 Radioactive Waste Management Site at the Nevada Test Site 
waiver for a disposal unit, such as U3ax/bl. Also, DOE Order 5820.2A requires site characterization of RWMSs.

Site characterization at disposal units within the Area 3 RWMS must address the possibility that subsidence craters and their respective alluvial chimneys (regions of alluvium lying between the collapsed subsurface cavity created by the detonation of a nuclear device and the corresponding subsidence crater; also termed "collapse zone”) act as pathways for contaminant migration. Researchers have suggested that chimneys might provide enhanced pathways for the migration of water into the uppermost aquifer (Borg et al., 1976; Tyler et al., 1992).

Tyler et al. (1992) compared the hydrogeologic conditions, using water content and water potential data, inside and outside an alluvial chimney. They found evidence of enhanced infiltration and wetter soil conditions within an alluvial chimney than in the alluvium outside the chimney. They posited that this enhanced infiltration resulted from ephemeral ponding of water in the crater. However, no significant differences in physical properties, as indicated by bulk density data, or hydrogeologic properties, as indicated by saturated hydraulic conductivity data, were discernable between the alluvium inside and outside the chimney. These results suggest that once a crater is filled with material, thereby preventing ponding, enhanced infiltration might no longer occur.

REECo (1994a) developed a conceptual model describing the potential for migration of liquids from the disposal unit to the uppermost aquifer. This conceptual model was based on data obtained from a U3ax/bl waste inventory report (REECo, 1994b) and an archival literature search for existing site characterization data pertinent to U3ax/bl and the Area 3 RWMS (REECo, 1994a). The model suggests that the potential for leachate formation is small for two reasons: (1) the craters are filled with waste and soil, and (2) an engineered cover, designed to prevent water from contacting the waste, will be placed over the unit. As leachate is unlikely to exist, alluvial chimneys beneath the disposal unit are unlikely to act as enhanced contaminant pathways.

Boreholes D1 and U1 were drilled and sampled to compare hydrogeologic conditions of alluvium within the chimney (disturbed) below the waste disposal crater with those of alluvium outside the chimney (undisturbed), respectively. Whether Borehole D1 actually penetrated the chimney is uncertain, because technical problems (Section 2.3) ended drilling of this borehole before the target slant depth was reached. 
Throughout this report, the term "disturbed alluvium" is used to mean alluvium contained in or bordering the chimney resulting from an underground nuclear test. While chimney formation has subjected such alluvium to collapse, it does not necessarily follow that any of the physical, hydrogeologic, or pneumatic properties were altered.

\subsection{Data Objectives of the Drilling Project}

The data objectives listed below were identified to ensure that the appropriate data were collected to support site characterization and to test the initial conceptual model.

- Obtain core and drill cuttings samples to characterize physical, hydrogeologic, and pneumatic properties of disturbed and undisturbed alluvium in the upper vadose zone.

- Measure concentrations of environmental tracers and hydrogeologic parameters in the core samples to estimate soil water fluxes in the upper vadose zone of the disturbed and undisturbed alluvium.

- Determine if contaminants, whether from the disposal unit itself or from nuclear testing, are present below the U3ax/bl disposal unit.

- Obtain access for geophysical logging of the boreholes, which will make periodic measurement of in-situ water content possible.

\subsection{Scope of Report}

This report includes the following information:

- Descriptions of the drilling, sampling, and laboratory testing methods

- Documentation for the data collected from the drilling and sampling activities (appendices)

- Preliminary interpretations of the data

\subsection{Site Description}

The NTS is located in southern Nevada, approximately 105 kilometers (km) (65 miles [mi]) northwest of Las Vegas. The NTS encompasses 3,561 square kilometers (1,375 square miles) of arid basin-and-range lands in southern Nye County. The NTS is surrounded on the east, north, and west by the Nellis Air Force Test and Training Range, a government-owned, restrictedaccess area.

The Area 3 RWMS is located within the south-central part of Yucca Flat, an alluvium-filled, topographically closed basin (Figure 1-2). The U3ax/bl disposal unit, located within the Area 3 


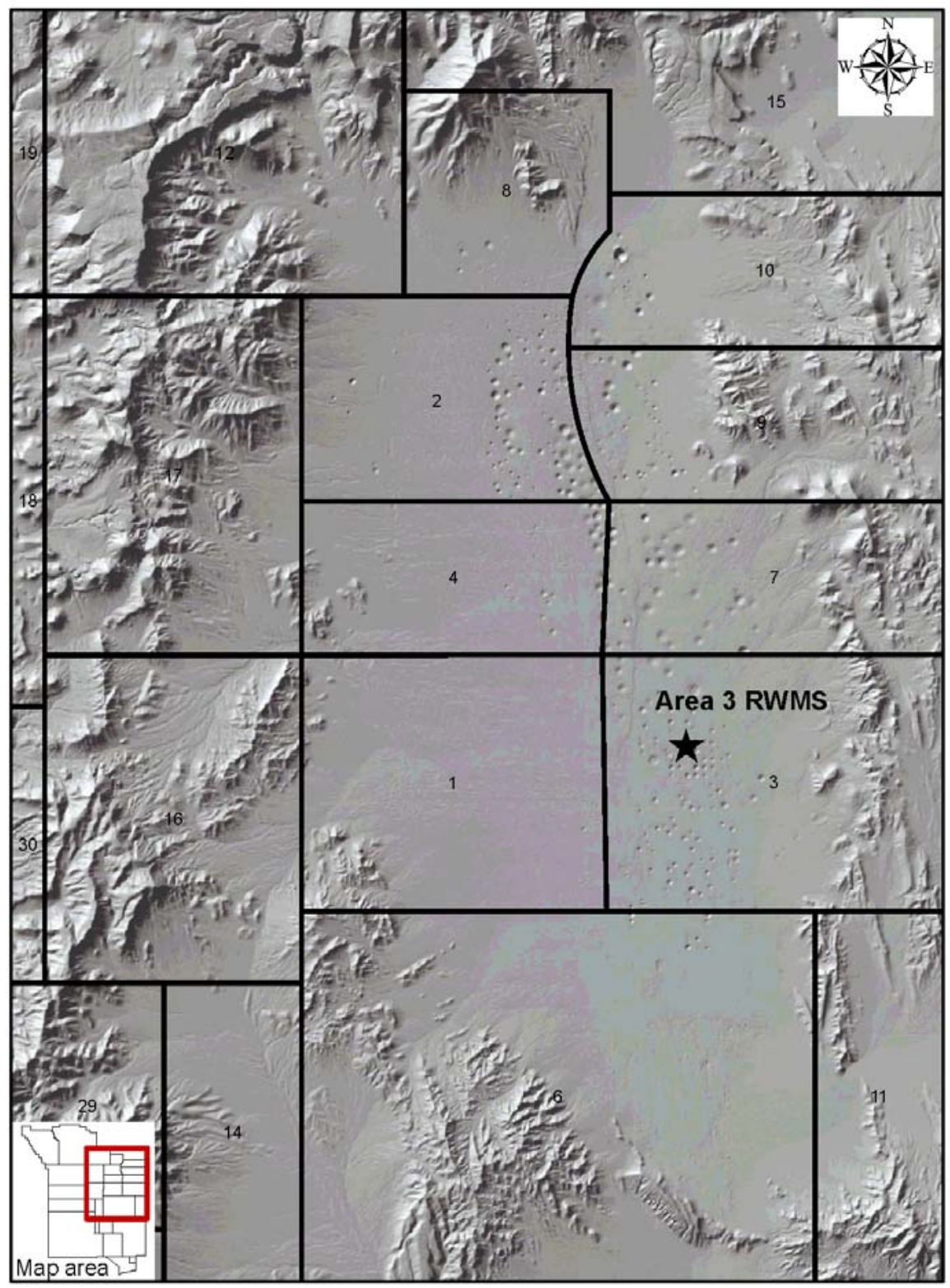

Figure 1-2

Location of the Area 3 Radioactive Waste Management Site in Yucca Flat 
This page intentionally left blank. 
RWMS, is situated at an elevation of approximately 1,225 m (4,020 ft), which is $32 \mathrm{~m} \mathrm{(106} \mathrm{ft)}$ above the Yucca playa, an ephemeral lake at the southern end of Yucca Flat. The ground surface at the Area 3 RWMS slopes primarily from north to south at 0.5 -percent grade.

Alluvium beneath U3ax/bl is composed primarily of unconsolidated to partially consolidated gravelly sand, eolian sand, and colluvium eroded from the surrounding mountains during the main period of basin development, and deposited on alluvial fans by debris flow and sheet-flood processes. The alluvial fans coalesce to form discontinuous, gradational, and poorly sorted deposits of detritus derived from volcanic and Paleozoic-age sedimentary rocks. The thickness of the alluvium beneath U3ax/bl is estimated to be $370 \mathrm{~m}(1,200 \mathrm{ft})$ according to Drellack (1994), and to be $460 \mathrm{~m}$ (1,500 ft) according to Fernald (1974). The uppermost aquifer is at a depth of approximately $490 \mathrm{~m}$ (1,600 ft), and is located in the Tertiary-age volcanic rocks (Doty and Thordarson, 1983). Existing hydrogeologic data pertinent to U3ax/bl (REECo, 1994a) suggest that the undisturbed alluvium beneath the Area 3 RWMS is hydrogeologically homogeneous and that no barriers to flow, such as carbonate horizons, are present.

The climate and meteorology of the region are typical of the upper Mojave desert province. Annual precipitation in Yucca Flat averages less than 180 millimeters (mm) (7 inches [in.]), and the annual potential evaporation typically exceeds $1,525 \mathrm{~mm}$ (60 in.) (REECo, 1994a). Most precipitation falls during two peak seasons, with a greater peak in the winter and a lesser in the summer.

Precipitation during the winter months is governed by the formation of a high pressure ridge in the Pacific and an accompanying low pressure cell in the Gulf of Alaska, known as the Aleutian Low. This combination often forces cold, wet air masses from the Pacific Northwest over the Great Basin and the Rocky Mountains, typically resulting in low-intensity rainfall and occasional snowfall at the Area 3 RWMS. Summer precipitation usually develops during convective storms caused by moisture moving up from the Gulf of California and the Gulf of Mexico. Convective storms are generally localized, of high intensity, and typically have a duration of six hours or less (Christiansen and Spahr, 1980). Although winter storms are often less intense than summer storms, they account for most of the annual moisture at the NTS, due to their longer duration.

The temperature range in Yucca Flat varies widely both with seasons and during a single day. During December, on average the coolest month, the average daily maximum and minimum temperatures are 11 degrees Celsius $\left({ }^{\circ} \mathrm{C}\right)\left(52\right.$ degrees Fahrenheit $\left.\left[{ }^{\circ} \mathrm{F}\right]\right)$ and $-7^{\circ} \mathrm{C}\left(20^{\circ} \mathrm{F}\right)$, respectively. During July, on average the warmest month, the average daily maximum and 
minimum temperatures are $36^{\circ} \mathrm{C}\left(96^{\circ} \mathrm{F}\right)$ and $14^{\circ} \mathrm{C}\left(57^{\circ} \mathrm{F}\right)$, respectively. Wind direction is primarily from either the north or the south. Wind speed ranges from calm to over 27 meters per second (m/s) (60 miles per hour [mi/hr]). The annual average wind speed for January 1962 through April 1978 was $3.2 \mathrm{~m} / \mathrm{s}(7.2 \mathrm{~m} / \mathrm{hr})$. January and November are the calmest months, with wind speeds averaging $2.7 \mathrm{~m} / \mathrm{s}(6.0 \mathrm{mi} / \mathrm{hr})$. April is the windiest month, with an average wind speed of $4.0 \mathrm{~m} / \mathrm{s}(9.0 \mathrm{mi} / \mathrm{hr})$.

\subsection{Testing and Waste Management Activities}

Nuclear tests were conducted at Yucca Flat from 1951 to 1992, and included both surface and underground tests (DOE, 2000). Within Area 3, underground nuclear tests were sponsored primarily by Los Alamos National Laboratory.

Underground nuclear tests within Yucca Flat have created hundreds of subsidence craters. Seven subsidence craters are located within the Area 3 RWMS: U3ah, U3at, U3ax, U3az, U3bg, U3bh, and U3bl (Figure 1-3). Four of these craters, U3ah, U3at, U3ax, and U3bl, have been used as disposal units. The remaining craters, U3az, U3bg, and U3bh, have not been used as waste disposal units, and may or may not eventually be so used. The area between the U3ax and U3bl craters was excavated to form the U3ax/bl disposal unit, where mixed waste was disposed between the late 1960s and 1987. Similarly, the U3ah and U3at craters were combined to form the U3ah/at disposal unit. The U3ah/at disposal unit, which has been in operation since 1988, is and has been used exclusively for the disposal of low-level radioactive waste.

The underground nuclear tests that created the U3ax and U3bl craters were named PACA (detonated on May 7, 1962) and BOBAC (detonated on August 24, 1962) (DOE, 2000). The PACA and BOBAC detonations occurred in alluvium above the water table, at depths of 258 and $195 \mathrm{~m}$ (846 and $640 \mathrm{ft}$ ), respectively. Each had a yield of less than 20 kilotons (DOE, 2000). The U3ax subsidence crater measured approximately $19 \mathrm{~m}$ (62 ft) deep and $138 \mathrm{~m}$ (453 ft) in diameter, with an approximate volume of 88,000 cubic meters $\left(\mathrm{m}^{3}\right) 115,000$ cubic yards $\left[\mathrm{yd}^{3}\right]$ ). The U3bl subsidence crater measured approximately $14 \mathrm{~m}$ (46 ft) deep and $122 \mathrm{~m}$ (400 ft) in diameter, with an approximate volume of $50,000 \mathrm{~m}^{3}\left(65,000 \mathrm{yd}^{3}\right)$. The volume of the conjoined U3ax/bl disposal unit is approximately 228,400 $\mathrm{m}^{3}\left(298,800 \mathrm{yd}^{3}\right)$.

During the operational life of the U3ax/bl disposal unit, 80 to 90 percent of the waste placed there originated from the NTS Waste Consolidation Project (REECo, 1994b). This project 


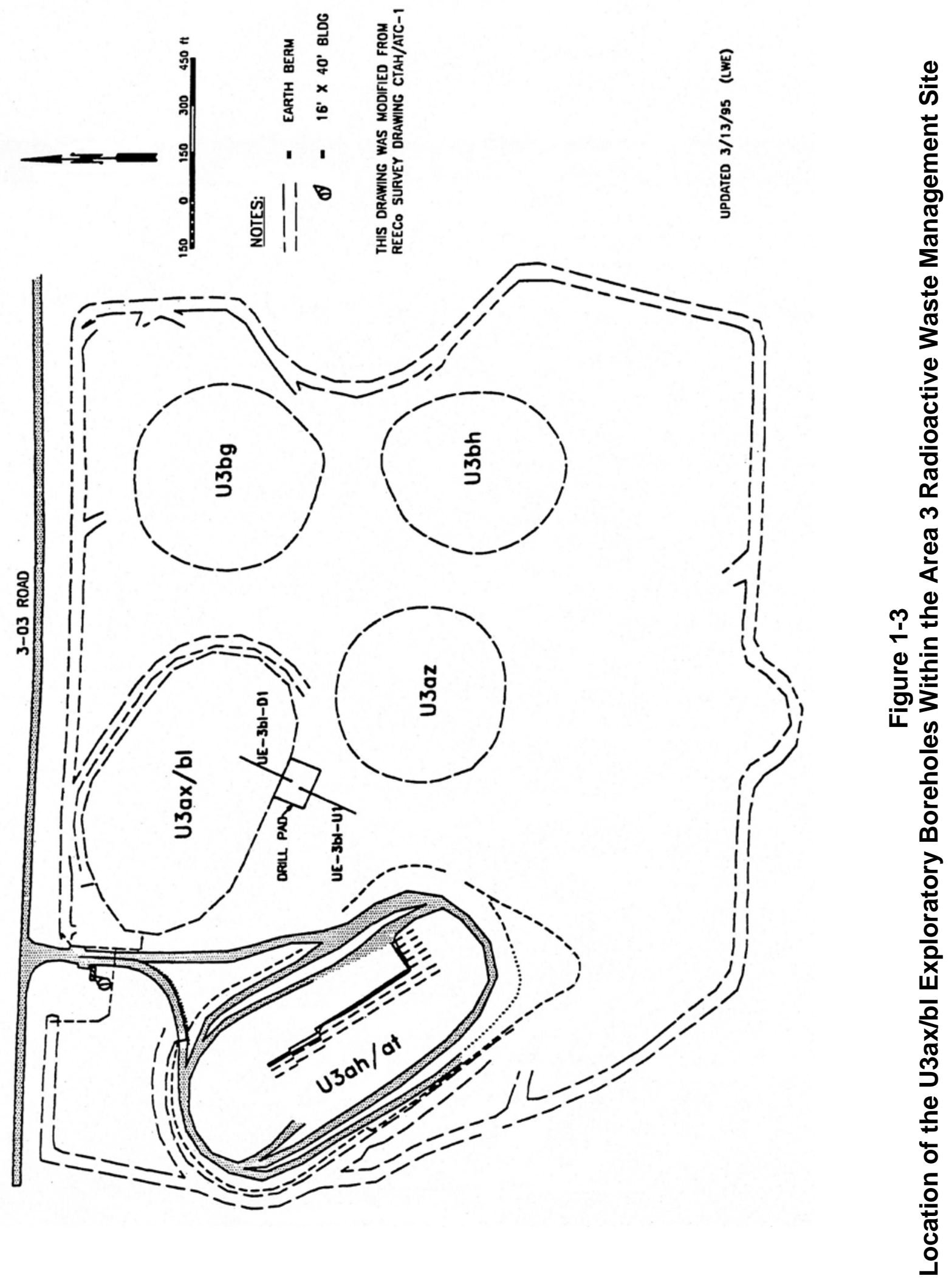


consolidated debris contaminated by atmospheric nuclear testing. The remaining waste originated from offsite activities or from weapons tests conducted in the NTS Area 12 tunnels. Further description of waste sources, characteristics, and quantity disposed in U3ax/bl can be found in REECo (1994b).

An engineered dirt cover was installed on the U3ax/bl waste disposal unit in 2000. Moisture sensors were installed at various depths in the cover to monitor the stability of soil moisture conditions within the upper $2.4 \mathrm{~m}(8 \mathrm{ft})$ of the cover (BN, 2000).

\subsection{Drill Site Location}

The drill site for boreholes D1 and U1 is located adjacent to the U3ax/bl disposal unit within the Area 3 RWMS (Figure 1-3). Table 1-1 provides the drilling depths and location data for the two exploratory boreholes.

Table 1-1

Drilling and Location Data for the U3ax/bl Exploratory Boreholes

\begin{tabular}{|c|c|c|c|c|c|c|c|c|}
\hline \multirow{2}{*}{ Borehole } & \multicolumn{2}{|c|}{ Drilling Dates } & \multirow{2}{*}{$\begin{array}{l}\text { Approximate } \\
\text { Bearing and } \\
\text { Inclination }\end{array}$} & \multicolumn{3}{|c|}{$\begin{array}{c}\text { Ground Surface Location }{ }^{\text {a }} \\
\text { meters (feet) }\end{array}$} & \multirow{2}{*}{$\begin{array}{c}\text { Total } \\
\text { Borehole } \\
\text { Depth } \\
\text { beters } \\
\text { (feet) } \\
\end{array}$} & \multirow{2}{*}{$\begin{array}{c}\text { Vertical } \\
\text { Depth of } \\
\text { Borehole } \\
\text { meters } \\
\text { (feet) } \\
\end{array}$} \\
\hline & Start & End & & North & East & Elevation & & \\
\hline UE-3bl-D1 & 06/27/1994 & 08/02/1994 & $\begin{array}{c}\mathrm{N} 26^{\circ} \mathrm{E} \\
-45^{\circ}\end{array}$ & $\begin{array}{c}254,869 \\
(836,183)\end{array}$ & $\begin{array}{c}209,536 \\
(687,455)\end{array}$ & $\begin{array}{c}1,223 \\
(4,013)\end{array}$ & $\begin{array}{c}74 \\
(242)\end{array}$ & $\begin{array}{c}50 \\
(163)\end{array}$ \\
\hline UE-3bl-U1 & 08/05/1994 & 09/06/1994 & $\begin{array}{c}\mathrm{S} 25^{\circ} \mathrm{E} \\
-45^{\circ}\end{array}$ & $\begin{array}{c}254,862 \\
(836,161)\end{array}$ & $\begin{array}{c}209,527 \\
(687,423)\end{array}$ & $\begin{array}{r}1,223 \\
(4,103) \\
\end{array}$ & $\begin{array}{c}76 \\
(250)\end{array}$ & $\begin{array}{c}50 \\
(164)\end{array}$ \\
\hline
\end{tabular}

a Nevada State Central Zone Coordinates, 1927 North American Datum. 1929 National Geodetic Vertical Datum.

b Slant depth, as measured along the borehole path. 


\subsection{Drilling, Sampling, and Completion}

This section provides an overview of the drilling, sampling, and completion methods. For details of these methods, see REECo (1993) and BN (2005a). Additional procedures and plans applicable to these activities are listed in Table 2-1.

Table 2-1

REECo Standard Operating Procedures Applicable to the U3ax/bl Exploratory Boreholes

\begin{tabular}{||l|l|c||}
\hline \multicolumn{1}{|c|}{ Title } & Procedure Number & \multicolumn{1}{c||}{ Date } \\
\hline \hline $\begin{array}{l}\text { Quality Assurance Plan for Site Characterization and } \\
\text { Monitoring Tasks }\end{array}$ & ER\&TDD-SP.01.28 & $02 / 28 / 1994$ \\
\hline Handling and Transport of Characterization Samples & ER\&TDD-SP.01.04 & $06 / 23 / 1994$ \\
\hline Geologic Logging of Alluvium (Draft) & ER\&TDD-SP.01.23 & $02 / 16 / 1994$ \\
\hline Gravimetric Moisture Content Determination (Draft) & ER\&TDD-SP.01.05 & $02 / 16 / 1994$ \\
\hline Stemming Well Screen, Casing, and Instruments (Draft) & ER\&TDD-SP.01.16 & $02 / 16 / 1994$ \\
\hline Borehole Abandonment (Draft) & ER\&TDD-SP.01.17 & $02 / 16 / 1994$ \\
\hline
\end{tabular}

\subsection{Borehole Preparation}

Two 3-m (10-ft) lengths of directional casing were placed in the ground at 45-degree angles before boreholes U1 and D1 were drilled. Each casing required the excavation of a 0.5-m

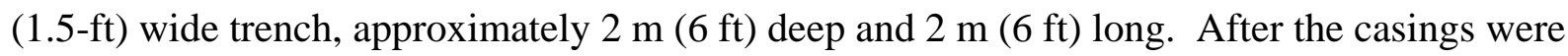
set at the desired angle and direction, they were secured by filling each trench with concrete.

Directional casing was used for two reasons: (1) to ensure that the boreholes were drilled, at least initially, at the proposed angle and direction, and (2) to reduce the amount of airborne dust released during drilling. Dust control was an item of high priority, as areas within the Area 3 RWMS are potentially contaminated by radioactive fallout from past atmospheric nuclear testing.

The outside diameter (O.D.) of the directional casing was $193 \mathrm{~mm}$ (7.6 in.), slightly larger than the casing used in the casing-advance under-reaming (CAU) drilling system (Section 2.3). This size casing was chosen so that the drilling tools and casing could pass through, yet the directional casing would still guide the borehole direction and angle. 
The REECo Analytical Services Department (ASD) analyzed excavated soil from both trenches for radiological materials, RCRA-regulated metals, volatile organic compounds (VOCs), and semi-VOCs. Based on these analyses, the REECo Waste Management Department classified the excavated soil as non-RCRA and non-radioactive waste.

\subsection{Dust Control System}

Drilling can disperse airborne particulates, so a dust control system was used to limit the spread of particulates into the atmosphere. In this system, drill cuttings are directed through a return line into the Newsom ${ }^{\circledR}$ Model 110 dust control system, consisting of a main cyclone separator, which captures and separates about 98 percent of the drill cuttings, and an electric-powered, vacuum-operated, high efficiency dust filter unit, which traps over 99.9 percent of the remaining dust particles. This combination of cyclone separator and high efficiency dust filter prevents dust particles with a diameter greater than 0.3 micrometers from escaping. Drill cuttings captured by the cyclone separator were directed into a $0.21-\mathrm{m}^{3}$ (55-gallon [gal]) metal drum.

\subsection{Drilling and Casing}

The subcontractor, Boyles Brothers Drilling Company, drilled boreholes U1 and D1 using a CAU drilling system. The drill rig was a Schramm ${ }^{\circledR}$ T685H rig with an angle package. The CAU drilling system used a Tubex ${ }^{\circledR} 140$ system with a Mission ${ }^{\circledR}$ D-5 down-hole hammer and dual-wall reverse circulation. The diameter of the borehole was approximately $188 \mathrm{~mm}$ (7.4 in.). The casing was carbon steel Christiansen Drive-Ex ${ }^{\circledR}$ System 140. The O.D. of the casing was $168 \mathrm{~mm}$ (6.6 in.), and the inner diameter (I.D.) was approximately $152 \mathrm{~mm}$ (6.0 in.). During drilling, cuttings were transported up the borehole by compressed air and directed into the dust control system.

In the CAU drilling system, the borehole is lined with casing as the hole is drilled. This system uses compressed air as the drilling fluid. Compressed air is less disruptive to the hydrogeologic conditions of the drill cuttings, core samples, and formation than other drilling fluids.

The major advantage of a CAU system is that it prevents the borehole from collapsing during drilling. Therefore, CAU systems are well suited for use in unconsolidated alluvium, where borehole collapse is a constant risk. The major disadvantage of a CAU system is that the casing can detach, breaking into two parts. When the casing detaches, the break usually occurs near the bottom of the borehole, where stress on the casing is greatest. If the casing detaches, it can no longer advance and must be removed from the borehole before drilling with a new casing can 
resume. However, removal of the casing might be impossible, since the forces that caused the casing to detach might also prevent removal.

The casing in both exploratory boreholes detached at slant depths of approximately $75 \mathrm{~m}$ (245 ft), $17 \mathrm{~m}$ (55 ft) short of the proposed depths for both boreholes. When the casing detached in Borehole D1, drilling was stopped and no attempt was made to remove the casing. This decision was influenced by deadlines, budget constraints, and engineering judgement, which indicated that the casing could probably not be removed. Because drilling ended prematurely, it is not certain that the borehole entered the U3bl chimney. Borehole U1, drilled next to U3ax/bl into undisturbed alluvium, also failed to reach its target depth. However, detachment of the casing of Borehole U1 was of lesser consequence than that of Borehole D1. The data objective for Borehole U1, to obtain hydrogeologic data from the undisturbed, near-surface alluvium, was achieved. Chronological drilling summaries for both boreholes are provided in Appendix A.

\subsection{Sampling for Hydrogeologic and Environmental Tracer Data}

Geologic samples, both cores and drill cuttings, were collected, described, and handled as described in REECo (1993, 1995) and BN (2005a). Drill cuttings samples were collected at 0.76-m (2.5-ft) intervals, and core samples were collected at 3-m (10-ft) intervals. The sample collection and handling procedures used (Table 2-1) were developed to reduce the loss of water by evaporation and to reduce disturbance of the physical integrity of the core samples.

\subsubsection{Collection of Samples}

Core samples were collected from the alluvium at selected intervals (Tables 2-2 and 2-3) employing a drive core sampler. An air-percussion hammer was used to drive a 0.76-m (2.5-ft) long by 114-mm (4.5-in.) O.D. solid-tube core barrel, containing clear Lexan ${ }^{\circledR}$ segments (76-mm [3.0-in.] long by 81-mm [3.2-in.] I.D.) to contain the sample material. The method was chosen because it provides good core recovery and reduces the disturbance of hydrogeologic conditions and properties of relatively dry, coarse-grained, unconsolidated alluvial samples (Hammermeister et al., 1986). The possible effects of coring on the values of parameters sensitive to pore-size distribution are discussed in BN (2005a). Always, core barrels were transported to a temperature-controlled field laboratory for geologic description and disposition as soon as possible after removal from the borehole. 
Table 2-2

Core Record for Borehole UE-3bl-D1

\begin{tabular}{|c|c|c|c|c|c|c|c|}
\hline \multirow{2}{*}{ Date } & \multirow{2}{*}{$\begin{array}{c}\text { Run } \\
\text { Number }\end{array}$} & \multicolumn{2}{|c|}{$\begin{array}{l}\text { Core Interval } \\
\text { (meters) }\end{array}$} & \multicolumn{2}{|c|}{ Core Recovery } & \multirow{2}{*}{$\begin{array}{l}\text { Penetration } \\
\text { Rate } \\
\text { (minutes per } \\
\text { meter) }\end{array}$} & \multirow{2}{*}{$\begin{array}{l}\text { Laboratory } \\
\text { Tests }\end{array}$} \\
\hline & & From & To & Meters & Percent & & \\
\hline 06/27/1994 & 1 & 3.81 & 4.06 & 0.00 & 0 & 11.54 & None \\
\hline 06/28/1994 & 2 & 6.10 & 6.86 & 0.61 & 80 & 8.14 & $A, B, C, D, E, F, G$ \\
\hline 06/29/1994 & 3 & 9.14 & 9.91 & 0.30 & 40 & 4.27 & $A, C, F, G$ \\
\hline 06/29/1994 & 4 & 12.19 & 12.95 & 0.76 & 100 & 8.40 & $A, B, C, D, E, F, G$ \\
\hline 06/30/1994 & 5 & 15.24 & 16.00 & 0.53 & 70 & 2.76 & $A, B, C, E, F, G$ \\
\hline 07/11/1994 & 6 & 18.29 & 18.90 & 0.61 & 100 & 21.33 & $A, B, D, F, G$ \\
\hline 07/11/1994 & 7 & 21.34 & 22.10 & 0.76 & 100 & 19.68 & $A, B, C, D, E, F, G$ \\
\hline 07/12/1994 & 8 & 24.38 & 25.15 & 0.76 & 100 & 7.87 & $A, B, C, D, E, F, G$ \\
\hline 07/12/1994 & 9 & 27.43 & 28.19 & 0.00 & 0 & 9.19 & None \\
\hline 07/13/1994 & 10 & 30.48 & 31.09 & 0.61 & 100 & 25.75 & $A, B, C, D, E, F$ \\
\hline 07/13/1994 & 11 & 33.53 & 34.29 & 0.76 & 100 & 8.27 & $A, B, C, E, F, G$ \\
\hline 07/15/1994 & 12 & 36.58 & 37.34 & 0.76 & 100 & 3.67 & $A, B, C, D, E, F, G$ \\
\hline 07/18/1994 & 13 & 39.62 & 40.39 & 0.76 & 100 & 4.59 & $A, B, C, E, F, G$ \\
\hline 07/19/1994 & 14 & 42.67 & 43.43 & 0.38 & 50 & 1.97 & $D, G$ \\
\hline 07/21/1994 & 15 & 45.72 & 46.48 & 0.46 & 60 & 3.54 & $B, D, G$ \\
\hline 07/25/1994 & 16 & 48.77 & 49.53 & 0.23 & 30 & 6.82 & $B, D, G$ \\
\hline 07/25/1994 & 17 & 51.82 & 52.58 & 0.76 & 100 & 8.14 & $A, B, C, D, E, F, G$ \\
\hline 07/26/1994 & 18 & 54.86 & 55.63 & 0.76 & 100 & 3.41 & $A, B, C, D, E, F, G$ \\
\hline 07/26/1994 & 19 & 57.91 & 58.67 & 0.00 & 0 & 3.94 & None \\
\hline 07/27/1994 & 20 & 60.96 & 61.72 & 0.76 & 100 & 2.49 & $A, B, C, D, E, F, G$ \\
\hline 07/28/1994 & 21 & 64.01 & 64.77 & 0.76 & 100 & 3.02 & $A, B, C, D, E, F, G$ \\
\hline 07/29/1994 & 22 & 67.06 & 67.82 & 0.76 & 100 & 5.25 & $A, B, C, D, E, F, G$ \\
\hline 07/29/1994 & 23 & 70.10 & 70.87 & 0.69 & 90 & 1.71 & $A, B, C, D, E, F, G$ \\
\hline 08/01/1994 & 24 & 73.15 & 73.91 & 0.69 & 90 & 3.15 & $A, B, C, D, E, F, G$ \\
\hline
\end{tabular}
A: Physical and hydraulic properties
B: Inorganic carbon and cation exchange capacity
C: Water Potential, water content, density
D: Stable isotopes
E: Chloride-bromide, water content
F: Air permeability
G: Archive 
Table 2-3

Core Record for Borehole UE-3bl-U1

\begin{tabular}{|c|c|c|c|c|c|c|c|}
\hline \multirow{2}{*}{ Date } & \multirow{2}{*}{$\begin{array}{c}\text { Run } \\
\text { Number }\end{array}$} & \multicolumn{2}{|c|}{ Core Interval (meters) } & \multicolumn{2}{|c|}{ Core Recovery } & \multirow{2}{*}{$\begin{array}{l}\text { Penetration } \\
\text { Rate } \\
\text { (minutes per } \\
\text { meter) } \\
\end{array}$} & \multirow{2}{*}{$\begin{array}{c}\text { Laboratory } \\
\text { Tests }\end{array}$} \\
\hline & & From & To & meters & percent & & \\
\hline 08/04/1994 & 1 & 3.81 & 4.57 & 0.61 & 80 & 2.62 & $A, B, C, D, E, G$ \\
\hline 08/05/1994 & 2 & 6.10 & 6.86 & 0.69 & 90 & 3.28 & $A, B, C, D, E, F, G$ \\
\hline 08/05/1994 & 3 & 9.14 & 9.91 & 0.61 & 80 & 2.10 & $A, B, C, D, E, F, G$ \\
\hline 08/05/1994 & 4 & 12.19 & 12.95 & 0.61 & 80 & 6.96 & $A, B, C, D, E, F, G$ \\
\hline 08/05/1994 & 5 & 15.24 & 16.00 & 0.76 & 100 & 10.63 & $A, B, C, D, E, F, G$ \\
\hline 08/08/1994 & 6 & 18.29 & 19.05 & 0.76 & 100 & 3.54 & $A, B, C, D, E, F, G$ \\
\hline 08/09/1994 & 7 & 21.34 & 22.10 & 0.15 & 20 & 10.89 & $\mathrm{~B}, \mathrm{G}$ \\
\hline 08/09/1994 & 8 & 24.38 & 25.15 & 0.76 & 100 & 1.57 & $A, B, C, D, E, F, G$ \\
\hline 08/09/1994 & 9 & 27.43 & 28.19 & 0.76 & 100 & 9.58 & $A, B, C, E, F, G$ \\
\hline 08/11/1994 & 10 & 30.48 & 31.24 & 0.61 & 80 & 7.09 & $A, B, C, D, E, F, G$ \\
\hline 08/11/1994 & 11 & 33.53 & 34.29 & 0.61 & 80 & 4.46 & $A, B, C, E, F, G$ \\
\hline 08/12/1994 & 12 & 36.58 & 37.34 & 0.00 & 0 & 8.66 & None \\
\hline 08/17/1994 & 13 & 39.62 & 40.39 & 0.76 & 100 & 4.86 & $A, B, C, D, E, F, G$ \\
\hline 08/17/1994 & 14 & 42.67 & 42.95 & 0.76 & 278 & 20.68 & $A, B, C, D, E, G$ \\
\hline 08/17/1994 & 15 & 45.72 & 46.48 & 0.76 & 100 & 6.96 & $A, B, C, E, F, G$ \\
\hline 08/18/1994 & 16 & 48.77 & 49.53 & 0.76 & 100 & 6.04 & $A, B, C, D, E, F, G$ \\
\hline 08/18/1994 & 17 & 51.82 & 52.43 & 0.00 & 0 & 11.48 & None \\
\hline 08/19/1994 & 18 & 54.86 & 55.37 & 0.61 & 120 & 16.50 & $B, D, G$ \\
\hline 08/19/1994 & 19 & 57.91 & 58.37 & 0.23 & 50 & 7.35 & $\mathrm{~B}, \mathrm{G}$ \\
\hline 08/22/1994 & 20 & 60.96 & 61.72 & 0.76 & 100 & 11.68 & $A, B, C, D, E, F, G$ \\
\hline 08/22/1994 & 21 & 64.01 & 64.77 & 0.69 & 90 & 7.09 & $A, B, C, E, F, G$ \\
\hline 08/23/1994 & 22 & 67.06 & 67.82 & 0.76 & 100 & 4.99 & $A, B, C, D, E, F, G$ \\
\hline 08/23/1994 & 23 & 70.10 & 70.87 & 0.76 & 100 & 7.61 & $A, B, C, E, F, G$ \\
\hline 08/24/1994 & 24 & 73.15 & 73.76 & 0.00 & 0 & 8.86 & None \\
\hline 09/06/1994 & 25 & 75.44 & 76.20 & 0.76 & 100 & 3.94 & $A, B, C, D, E, F, G$ \\
\hline
\end{tabular}
A: Physical and hydraulic properties
B: Inorganic carbon and cation exchange capacity
C: Water Potential, water content, density
D: Stable isotopes
E: Chloride-bromide, water content
F: Air permeability
G: Archive 
Drill cuttings, which were only collected during initial drilling of any particular interval, were collected at $0.76-\mathrm{m}(2.5-\mathrm{ft})$ intervals. Drill cuttings were never collected during hole cleaning or related activities, to ensure that the collected drill cuttings represented the specified interval. Immediately after drilling each $0.76-\mathrm{m}$ (2.5-ft) interval, the valve on the cyclone separator's hopper was opened. As drill cuttings dropped into a $0.21-\mathrm{m}^{3}$ (55-gal) metal barrel, samples were collected in plastic bottles, moisture tins, and 3.8-liter (L) (1-gal) cans for selected intervals. Samples were then delivered immediately to a temperature-controlled field laboratory.

Samples in the moisture tins were used to measure the cuttings' gravimetric water content, and the samples in the 3.8-L (1-gal) cans were analyzed for tritium. The samples in the plastic bottles were designated as archive samples, however, those not used for tests reported in this document have since been discarded.

\subsubsection{Geologic Description and Storage of Samples}

To ensure that the water content of each sample represented in-situ hydrogeologic conditions, both core and drill cuttings samples were handled, in the field laboratory and during storage and transport, in a way that minimized evaporative water loss, according to procedures listed in Table 2-1.

The labeling system used in the field to assign core segments and drill cuttings samples for different laboratory tests is summarized in Table 2-4. Each sample label identifies the following: (1) the laboratory testing required, (2) the priority of the test(s), and (3) the testing laboratory responsible for conducting the analyses. These labels (e.g., DB1, DRI1) are used when referring to specific core and/or drill cuttings samples in various tables, figures, and appendices in this report.

Liner segments containing core samples were removed from the solid-tube drive core sampler by a hydraulic core extruder. A geologic description of the core was made by examining the open ends of each segment. This geologic description was recorded on field data sheets (Appendix B).

Following geologic description and measurement of magnetic susceptibility, each core segment was capped, taped, and labeled with the appropriate sample identification and intended laboratory test(s). Core segments were further sealed in Protec-Core ${ }^{\circledR}$, a tubular aluminized Mylar ${ }^{\circledR}$ laminate that protects the core from damage, tampering, and moisture loss when sealed. 
Table 2-4

Definitions of Core and Drill Cuttings Sample Labels for the U3ax/bl Exploratory Boreholes

\begin{tabular}{|c|c|c|c|c|c|}
\hline $\begin{array}{c}\text { Sample } \\
\text { Type }\end{array}$ & $\begin{array}{l}\text { Sample } \\
\text { Priority }\end{array}$ & $\begin{array}{l}\text { Sample } \\
\text { Condition }\end{array}$ & $\begin{array}{c}\text { Sample } \\
\text { ID }\end{array}$ & Laboratory Tests & Laboratory $^{a}$ \\
\hline \multirow{7}{*}{ Core } & 1 & Intact & DB1 & $\begin{array}{ll}\text { - } & \text { Saturated Hydraulic Conductivity } \\
\text { - } & \text { Moisture Retention Curves } \\
\text { - } & \text { Dry Bulk Density } \\
\text { - } & \text { Porosity } \\
\text { - } & \text { Particle Size Distribution } \\
\text { - } & \text { Hydrometer } \\
\text { Particle Density }\end{array}$ & DBS\&A \\
\hline & 2 & Intact & DRI1 & $\begin{array}{ll}\text { - } & \text { Water Content } \\
\text { - } & \text { Water Potential } \\
\text { Dry Bulk Density }\end{array}$ & DRI \\
\hline & 3 & Intact & AIR1 & - $\quad$ Air Permeability & REECo/SPS \\
\hline & 4 & Intact & HGC & $\begin{array}{l}\text { - Chloride-Bromide } \\
\text { - Water Content }\end{array}$ & HGC \\
\hline & 5 & $\begin{array}{l}\text { Intact or } \\
\text { Disturbed }\end{array}$ & DB2 & $\begin{array}{l}\text { - Inorganic Carbon } \\
\text { - } \quad \text { Cation Exchange Capacity }\end{array}$ & DBS\&A \\
\hline & 6 & $\begin{array}{l}\text { Intact or } \\
\text { Disturbed }\end{array}$ & DRI3 & - Stable Isotopes & DRI \\
\hline & $7-10$ & $\begin{array}{l}\text { Intact or } \\
\text { Disturbed }\end{array}$ & $\mathrm{ARCH}$ & - Archive $^{b}$ & REECo/SPS \\
\hline \multirow{3}{*}{$\begin{array}{l}\text { Drill } \\
\text { Cuttings }\end{array}$} & -- & $N / A^{c}$ & $\mathrm{ARCH}$ & - $\quad$ None ${ }^{d}$ & $\mathrm{~N} / \mathrm{A}$ \\
\hline & -- & $\mathrm{N} / \mathrm{A}$ & Depth & - Water Content & REECo/SPS \\
\hline & -- & N/A & DRI2 & - Tritium & DRI \\
\hline
\end{tabular}

a $\quad$ DBS\&A = Daniel B. Stevens and Associates

DRI = Desert Research Institute

REECo/SPS = Reynolds Electrical \& Engineering Co., Inc. Special Projects Section

HGC $=$ Hydro Geo Chem, Inc.

b Water content measurements were made on 3 archive core segments from Borehole D1 and 2 from Borehole U1, and reported as DB1 samples (see Section 3.6.1 and Appendix C). The remainder of the archive samples have been discarded.

c $\quad$ N/A = not applicable

d All archived drill cuttings samples have been discarded. 
An additional label containing the same information was then affixed. Most of the core segments were specified for various types of laboratory tests, while the remainder was stored for future use. Tables 2-2 and 2-3, and Appendix B summarize the specific laboratory tests designated for each core run.

The assignment of core segments for various tests was based on a priority system. This was done because core recovery was not always 100 percent, and the degree of disturbance to water content, porosity, and aggregation was not uniform among core segments. The assignment of core segments to tests was made with awareness of the relative importance of each laboratory tests, and the degree of sample disturbance acceptable for each test. This priority system is described in procedures listed in Table 2-1.

A brief geologic description of the drill cuttings samples (Appendix B) was made after the samples were transported to the temperature-controlled field laboratory. Sample bottles containing drill cuttings were opened briefly, and the same procedures for geologic description and magnetic survey, referred to previously for core samples, were followed. Sample bottles were capped, taped, sealed in Protec-Core ${ }^{\circledR}$, and labeled with appropriate sample identification information and intended tests. These drill cuttings samples were collected primarily for storage.

The samples collected in the moisture tins were designated for gravimetric water content measurements done by the field geologist. The moisture tins were labeled, capped, and taped to prevent water loss until they could be measured. The drill cuttings collected in the 3.8-L (1-gal) containers were capped and labeled, then sealed with bees' wax and tape. The application of bees' wax, although not included in the procedure for handling and transporting characterization samples (ER\&TDD-SP.01.04), was made to ensure that the seals of the containers were airtight. These samples were collected at selected intervals for tritium analysis.

\subsubsection{Radiological Surveys of Geologic Samples}

Gamma radiation levels from drill cuttings were monitored continuously with an energycompensated Geiger-Muller detector mounted directly onto the cyclone separator. A Radiological Control Technician (RCT) from the REECo Health Protection Department monitored the drill cuttings as they entered the $0.21-\mathrm{m}^{3}$ (55-gal) barrels, and when sediment samples were removed from the barrels. The RCT monitored core samples as they were removed from the core barrel. As a further precaution, the RCT daily collected many swipe samples from drilling and coring equipment, which were analyzed for removable alpha and beta contamination. 
Additionally, air particulate samples were collected weekly and analyzed for plutonium-239 and plutonium $240\left({ }^{239+240} \mathrm{Pu}\right)$ by REECo ASD personnel. No radiation above background levels was encountered during drilling.

\subsubsection{Characterization of Drill Cuttings}

Drill cuttings samples from both boreholes were analyzed for radiological and RCRA-regulated constituents. Besides protecting the health and safety of personnel working on the drill site or with the samples, analyses of drill cuttings aided in testing the conceptual hydrogeologic model. If contamination had been found in samples from Borehole D1, it would have provided evidence against the conceptual model, which predicts that contaminants will not migrate from the disposal unit. However, if contamination had been found, it would have been difficult to determine if it indicated migration from the disposal unit or if it was a result of earlier underground nuclear testing. As none was found, this issue is moot.

From each borehole, thirteen $0.21-\mathrm{m}^{3}$ (55-gal) barrels, a total of 26 barrels, were filled with drill cuttings. Each barrel contained drill cuttings from a 6-m (20-ft) slant-depth interval. Samples from 2 barrels representing adjacent 6-m (20-ft) intervals were combined, and the combined samples were analyzed for ${ }^{239+240} \mathrm{Pu}$, gamma emitters, tritium, RCRA-regulated metals, and semi-VOCs. Volatile organic compounds were not considered, because the pressurized air which transported the cuttings up the borehole would have volatilized any VOCs before the drill cuttings entered the dust control system.

Since the drill cuttings from Borehole D1 could be used to test the conceptual model, samples were taken from Borehole D1 throughout the borehole depth. Fewer samples were taken from Borehole $\mathrm{U} 1$ because it was not drilled beneath the disposal unit. Atmospheric nuclear testing is the only credible source of contamination for drill cuttings from Borehole U1. Since this contamination, if present, would primarily occur in the near-surface, samples were taken only from the upper $18 \mathrm{~m}(60 \mathrm{ft})$ of this borehole.

Other than small concentrations of tritium, no RCRA-regulated materials or radioactive materials were found in any of the samples. The tritium concentrations were less than 1 percent of the Nuclear Regulatory Commission's concentration limit of $1 \times 10^{6}$ picoCuries per liter (pCi/L) for effluent released to an unrestricted area (Title 10 CFR §20). A discussion of the results from the tritium analysis is presented in Section 3.6.3. 


\subsection{Borehole Completion}

After drilling was completed, a weather-proof cover was placed on the surface casing of each borehole. The concrete poured into each trench sets the surface casings at 45-degree angles and prevents precipitation or runoff from entering the borehole annulus. The two boreholes were monitored periodically with neutron loggers to evaluate moisture conditions of the alluvium surrounding the boreholes until the year 2000. To date, no instrumentation has been installed and the boreholes remain open. 


\subsection{Laboratory Testing Methods and Results}

A summary of laboratory tests and testing methods is given in Table 3-1. The cited references contain specific details. A description of all laboratory testing methods used to obtain cation exchange capacity (CEC), pneumatic properties (i.e., air permeability), and tritium concentrations appear in REECo (1993). These three methods are described in their respective sections: Cation-Exchange Capacity (Section 3.4.3); Pneumatic Properties (Section 3.7); and Tritium Profiles (Section 3.8.3).

\subsection{Testing Laboratories}

Core and drill cuttings samples were sent to the following testing laboratories where physical, hydrogeologic, and chemical properties were measured. REECo audited and approved the Quality Assurance (QA) programs of the following testing laboratories: Daniel B. Stevens \& Associates, Inc. (DBS\&A), Albuquerque, NM, and Hydro Geo Chem, Inc., (HGC), Tucson, AZ. DBS\&A was responsible for the review and approval of the QA program for the subcontracting laboratories that DBS\&A used (Dr. B. Branvold, New Mexico Institute of Mining and Technology, Socorro, NM, and Soil and Water West, Inc., Rio Rancho, NM). The QA program for the Desert Research Institute (DRI) laboratory was reviewed and approved by the predecessor to NNSA/NSO.

\subsection{Laboratory Test Results}

In most cases, testing laboratories conducted several related tests on a single core segment. For example, initial water content, bulk density, porosity, hydraulic conductivity, moisture retention, and particle size distribution measurements were conducted on the same 7.6-centimeter $(\mathrm{cm})$ (3-in.) core segment.

The types and numbers of tests conducted on core samples and drill cuttings for each borehole are summarized in Table 3-2. Results from all laboratory tests for both core and drill cuttings samples are given in tabular form in Appendix C. Summary statistics for laboratory measurements, where appropriate, are presented in Tables 3-3, 3-4, 3-5, and 3-6. Descriptive statistics for moisture retention curves appear in Table 3-7. Statistical calculations were done without outlier omission. Plots of laboratory results for specific tests, along with brief discussions of the data, are presented in the following sections. 


\section{Table 3-1}

\section{Summary of Laboratory Methods}

\begin{tabular}{|c|c|}
\hline Method Description & Reference \\
\hline $\begin{array}{l}\text { Geologic Description of } \\
\text { Unconsolidated Alluvium }\end{array}$ & $\begin{array}{l}\text { ASTM D 2488-84, 1990. Standard Practice for Description and } \\
\text { Identification of Soils - Visual Manual Procedure. In: } 1987 \text { Annual Book of } \\
\text { ASTM Standards, Vol. 04.08, American Society for Testing and Material. } \\
\text { Philadelphia, PA. }\end{array}$ \\
\hline Moisture Content & $\begin{array}{l}\text { ASTM D 2216-90, 1990. Method for Laboratory Determination of Water } \\
\text { (Moisture) Content of Soil, Rock, and Soil-Aggregate Mixtures. In: } 1990 \\
\text { Annual Book of ASTM Standards, Vol. 04.08, American Society for Testing } \\
\text { and Material. Philadelphia, PA. }\end{array}$ \\
\hline $\begin{array}{l}\text { - Dry Bulk } \\
\text { - Particle }\end{array}$ & 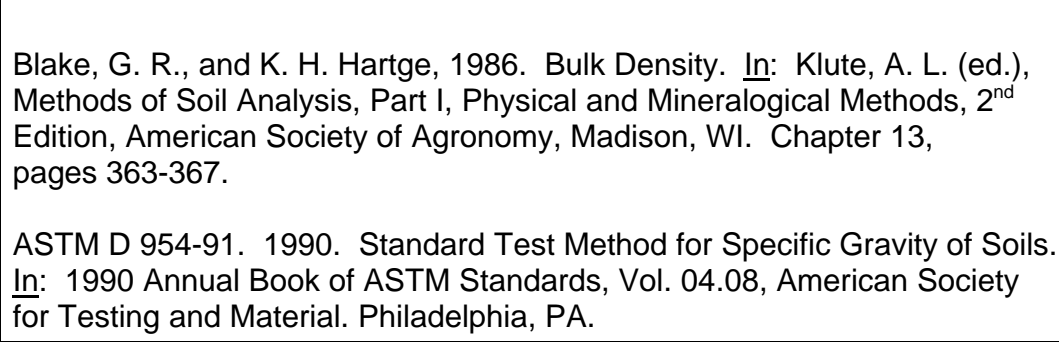 \\
\hline Porosity & $\begin{array}{l}\text { Danielson, R. E., and P. L. Sutherland, 1986. Total Porosity. In: Klute, } \\
\text { A. L. (ed.), Methods of Soil Analysis, Part I, Physical and Mineralogical } \\
\text { Methods, 2nd Edition, American Society of Agronomy, Madison, WI. } \\
\text { Chapter 18, pages 444-445. }\end{array}$ \\
\hline $\begin{array}{l}\text { Saturated Hydraulic Conductivity } \\
\text { - Constant Head } \\
\text { • Falling Head }\end{array}$ & $\begin{array}{l}\text { ASTM D 2434-68(74), 1974. Test Method for Permeability of Granular } \\
\text { Soils (Constant Head). In: } 1987 \text { Annual Book of ASTM Standards, Vol. } \\
\text { 04.08, American Society for Testing and Material. Philadelphia, PA. } \\
\text { Klute, A. L., and C. Dirksen, 1986. Hydraulic Conductivity and Diffusivity: } \\
\text { Laboratory Methods - Falling Head Method. In: Klute, A. L. (ed.), Methods } \\
\text { of Soil Analysis, Part I, Physical and Mineralogical Methods, } 2^{\text {nd }} \text { Edition, } \\
\text { American Society of Agronomy, Madison, Wl. Chapter 28, pages 700-703. }\end{array}$ \\
\hline • Hanging Column & $\begin{array}{l}\text { ASTM D 2325-68(81), 1981. Test Method for Capillary- Moisture } \\
\text { Relationships for Coarse- and Medium-Textured Soils by Pressure-Plate } \\
\text { Apparatus. In: } 1987 \text { Annual Book of ASTM Standards, Vol. 04.08, } \\
\text { American Society for Testing and Material. Philadelphia, PA. } \\
\text { Klute, A. L., 1986. Water Retention: Laboratory methods - Falling Head } \\
\text { Method. In: Klute, A. L. (ed.), Methods of Soil Analysis, Part I, Physical } \\
\text { and Mineralogical Methods, } 2^{\text {nd }} \text { Edition, American Society of Agronomy, } \\
\text { Madison, WI. Chapter 26, pages } 635-641 .\end{array}$ \\
\hline - Thermocouple Psychrometer & $\begin{array}{l}\text { Operator's Manual for the SC-10A Thermocouple Psychrometer Sample } \\
\text { Chamber (manufactured by Decagon Devices, Inc., Pullman, WA) }\end{array}$ \\
\hline $\begin{array}{l}\text { Particle Size Characteristics - } \\
\text { Wet and Dry Sieve }\end{array}$ & $\begin{array}{l}\text { ASTM D 422-63(90), 1990. Standard Method for Particle- Size analysis of } \\
\text { soils. In: } 1990 \text { Annual Book of ASTM Standards, Vol. 04.08, American } \\
\text { Society for Testing and Material. Philadelphia, PA. }\end{array}$ \\
\hline Water Potential & $\begin{array}{l}\text { Gee, G. W., M. D. Campbell, G. S. Campbell, and J. H. Campbell, } 1992 . \\
\text { Rapid Measurement of Low Soil Water Potential Using a Water Activity } \\
\text { Meter. Soil Science Society of America Journal, Vol. 56, } \\
\text { Pages 1,068-1,071. }\end{array}$ \\
\hline
\end{tabular}


Table 3-1

Summary of Laboratory Methods (continued)

\begin{tabular}{|c|c|}
\hline Method Description & Reference \\
\hline Air Permeability & $\begin{array}{l}\text { ER\&TDD-SP.01.25. Laboratory Air Permeability Measurements for } \\
\text { Geologic Core Samples. Reynolds Electrical \& Engineering Co., Inc. Las } \\
\text { Vegas, NV }\end{array}$ \\
\hline $\begin{array}{l}\text { Chloride and Bromide } \\
\qquad \text { Sample Leaching } \\
\text { • Ion Chromatography }\end{array}$ & $\begin{array}{l}\text { Los Alamos National Laboratory - Internal Document, 1992. Sample } \\
\text { Leaching to Extract Soluble Chloride and Bromide. LANL-INC-DP-92.R0. } \\
\text { Pages 9-15. } \\
\text { Los Alamos National Laboratory - Internal Document, 1991. Draft } \\
\text { Procedure for Using Ion Chromatography to Determine Chloride and } \\
\text { Bromide Concentrations. LANL-INC-DP-94.R0. Pages 3-25. }\end{array}$ \\
\hline $\begin{array}{l}\text { - Soil Water Extraction } \\
\text { - Analysis }\end{array}$ & $\begin{array}{l}\text { Ingraham, N. L. and C. Shadel, 1992. A Comparison of the Toluene } \\
\text { Distillation and Vacuum/Heat Methods for Extracting Soil Water for Stable } \\
\text { Isotope Analysis. Journal of Hydrology, Vol. 140, pages 371-387. } \\
\text { Packard, 1990. Operations Manual for Tri-Carb Liquid Scintillation 2500TR. }\end{array}$ \\
\hline Inorganic Carbon & $\begin{array}{l}\text { Nelson, R. E., 1982. Carbonate and Gypsum: Pressure-Calcimeter } \\
\text { Method. In: Page, A. L., R. H. Miller, and D. R. Keeney (eds.), Methods of } \\
\text { Soil Analysis, Part 2, Chemical and Microbiological Properties, } 2^{\text {nd }} \text { Edition, } \\
\text { American Society of Agronomy, Madison, WI, Chapter 11, pages 188-192. }\end{array}$ \\
\hline $\begin{array}{l}\text { - Oxygen Isotope Analysis } \\
\text { - Hydrogen Isotope Analysis } \\
\text { - Mass Spectrometry Analysis }\end{array}$ & $\begin{array}{l}\text { Ingraham, N. L. and C. Shadel, 1992. A Comparison of the Toluene } \\
\text { Distillation and Vacuum/Heat Methods for Extracting Soil Water for Stable } \\
\text { Isotope Analysis. Journal of Hydrology, Vol. 140, pages 371-387. } \\
\text { Revezs, K., an dP. H. Woods, 1990. A Method to Extract Soil Water for } \\
\text { Stable Isotope Analysis. Journal of Hydrology, Vol. 115, pages 397-406 } \\
\text { Dugan, J. P., J.Borthwich, R. S. Harmon, M. A. Gagnier, J. E. Glahn, E. P. } \\
\text { Kinsel, S. MacLeod, J. A. Viglino, and J. W. Hess, 1985. Guanidine } \\
\text { Hydrochloride Method for Determination of Water Oxygen Isotope Ratios } \\
\text { and the Oxygen-18 Fractionation Between Carbon Dioxide and Water at } \\
25^{\circ} \text {. Analytical Chemisty, Vol. 57, pages 1,734-1,736. } \\
\text { Kendall, C., and T. B. Coplen, 1985. Multisample Conversion of Water to } \\
\text { Hydrogen by Zinc for Stable Isotope Determination. Analytical Chemistry., } \\
\text { Vol. 57, pages 1,437-1,440. } \\
\text { Gonfiantini, R., 1981. The Del-Notation and the Mass Spectrographic } \\
\text { Measurements Techniques. International Atomic Energy Agency, } \\
\text { Technical Report Series No. 210, Chapter 4, pages 35-84. }\end{array}$ \\
\hline Cation-Exchange Capacity & $\begin{array}{l}\text { U.S. Environmental Protection Agency, September 1986. Cation-Exchange } \\
\text { Capacity of Soils (Sodium Acetate), Method 9081. In: Test Methods for } \\
\text { Evaluating Solid Waste (SW-486), Chapter 5, Miscellaneous Test Methods, } \\
\text { RO, } 4 \text { pages. }\end{array}$ \\
\hline
\end{tabular}


Table 3-2

Summary of the Numbers of Tests Performed on Samples from the U3ax/bl Exploratory Boreholes

\begin{tabular}{|c|c|c|c|c|c|}
\hline \multicolumn{2}{|r|}{ Test } & \multicolumn{2}{|c|}{ UE-3bl-D1 } & \multicolumn{2}{|c|}{ UE-3bl-U1 } \\
\hline & & Core & 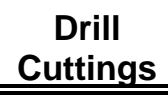 & Core & $\begin{array}{c}\text { Drill } \\
\text { Cuttings } \\
\end{array}$ \\
\hline \multirow{5}{*}{$\begin{array}{l}\text { Hydrologic } \\
\text { Properties and } \\
\text { Conditions }\end{array}$} & Saturated Hydraulic Conductivity & 18 & -- & 19 & -- \\
\hline & Moisture Retention Curves & 18 & -- & 19 & -- \\
\hline & Gravimetric Water Content & 55 & 93 & 59 & 95 \\
\hline & Volumetric Water Content & 55 & -- & 59 & -- \\
\hline & Total Water Potential & 16 & -- & 19 & -- \\
\hline \multirow{9}{*}{$\begin{array}{l}\text { Physical, } \\
\text { Pneumatic, } \\
\text { and Chemical } \\
\text { Properties }\end{array}$} & $\begin{array}{l}\text { Particle Size Distribution } \\
\text { Dry Sieve }\end{array}$ & 18 & -- & 19 & -- \\
\hline & Hydrometer & 8 & -- & 6 & -- \\
\hline & Dry Bulk Density & 34 & -- & 38 & -- \\
\hline & Particle Density & 18 & -- & 19 & -- \\
\hline & Porosity, Calculated & 34 & -- & 38 & -- \\
\hline & Porosity, Saturated & 18 & -- & 19 & -- \\
\hline & Air Permeability & 5 & -- & -- & -- \\
\hline & Calculated Permeability & 18 & -- & 19 & -- \\
\hline & Cation Exchange Capacity & 21 & -- & 23 & -- \\
\hline \multirow{4}{*}{$\begin{array}{l}\text { Environmental } \\
\text { Tracers }\end{array}$} & Inorganic Carbon & 21 & -- & 23 & -- \\
\hline & Chloride-Bromide & 18 & -- & 19 & -- \\
\hline & Stable Isotopes & 17 & -- & 15 & -- \\
\hline & Tritium & -- & 4 & -- & -- \\
\hline
\end{tabular}

Note: -- indicates test not performed. 
Table 3-3

Summary of Descriptive Statistics for Physical and Pneumatic Properties for Core Samples from the U3ax/bl Exploratory Boreholes

\begin{tabular}{|c|c|c|c|c|c|c|c|}
\hline & \multirow{2}{*}{$\begin{array}{l}\text { Sample } \\
\text { ID }\end{array}$} & \multirow{2}{*}{$\begin{array}{c}\text { Number of } \\
\text { Samples }\end{array}$} & \multicolumn{2}{|c|}{ Range } & \multirow{2}{*}{ Mean } & \multirow{2}{*}{$\begin{array}{l}\text { Standard } \\
\text { Deviation }\end{array}$} & \multirow{2}{*}{$\begin{array}{c}\text { Coefficient } \\
\text { of Variation } \\
\text { (percent) }\end{array}$} \\
\hline & & & Minimum & Maximum & & & \\
\hline \multicolumn{8}{|c|}{ Sieve Analysis (percent passing Number 4 mesh screen) } \\
\hline UE-3bl-D1 & \multirow{2}{*}{ DB1 } & 18 & 51.6 & 98.8 & 87.9 & 11.5 & 13.1 \\
\hline UE-3bl-U1 & & 19 & 53.0 & 97.8 & 83.5 & 14.8 & 17.7 \\
\hline \multicolumn{8}{|c|}{ Sieve Analysis (percent passing Number 200 mesh screen) } \\
\hline UE-3bl-D1 & \multirow{2}{*}{ DB1 } & 18 & 1.8 & 35.3 & 13.8 & 11.3 & 81.7 \\
\hline UE-3bl-U1 & & 19 & 1.9 & 14.5 & 7.5 & 4.6 & 60.7 \\
\hline \multicolumn{8}{|c|}{ Dry Bulk Density (grams per cubic centimeter) } \\
\hline \multirow[t]{3}{*}{ UE-3bl-D1 } & DB1 & 18 & 1.25 & 1.64 & 1.44 & 0.11 & 8.0 \\
\hline & DRI1 & 16 & 1.16 & 1.75 & 1.46 & 0.14 & 9.3 \\
\hline & TOTAL & 34 & 1.16 & 1.75 & 1.45 & 0.12 & 8.5 \\
\hline \multirow[t]{3}{*}{ UE-3bl-U1 } & DB1 & 19 & 1.25 & 1.75 & 1.47 & 0.11 & 7.3 \\
\hline & DRI1 & 19 & 1.27 & 1.69 & 1.51 & 0.12 & 8.1 \\
\hline & TOTAL & 38 & 1.25 & 1.75 & 1.49 & 0.12 & 7.7 \\
\hline \multicolumn{8}{|c|}{ Particle Density (grams per cubic centimeter) } \\
\hline UE-3bl-D1 & \multirow{2}{*}{ DB1 } & 18 & 2.50 & 2.60 & 2.55 & 0.03 & 1.0 \\
\hline UE-3bl-U1 & & 19 & 2.44 & 2.58 & 2.53 & 0.04 & 1.5 \\
\hline \multicolumn{8}{|c|}{ Porosity, calculated (percent) } \\
\hline \multirow[t]{3}{*}{ UE-3bl-D1 } & DB1 & 18 & 36.3 & 51.2 & 43.7 & 4.3 & 9.9 \\
\hline & DRI1 & 16 & 31.3 & 54.5 & 42.6 & 5.3 & 12.5 \\
\hline & TOTAL & 34 & 31.3 & 54.5 & 43.1 & 4.8 & 11.1 \\
\hline \multirow[t]{3}{*}{ UE-3bl-U1 } & DB1 & 19 & 31.7 & 49.7 & 41.8 & 4.1 & 9.8 \\
\hline & DRI1 & 19 & 33.1 & 49.7 & 40.1 & 4.8 & 12.1 \\
\hline & TOTAL & 38 & 31.7 & 49.7 & 41.0 & 4.5 & 11.0 \\
\hline \multicolumn{8}{|c|}{ Porosity, saturated (percent) } \\
\hline UE-3bl-D1 & \multirow{2}{*}{ DB1 } & 18 & 29.2 & 48.2 & 39.9 & 5.3 & 13.4 \\
\hline UE-3bl-U1 & & 19 & 29.3 & 44.1 & 37.9 & 4.0 & 10.5 \\
\hline \multicolumn{8}{|c|}{ Air Permeability (square meters) } \\
\hline UE-3bl-D1 & \multirow{2}{*}{ AIR } & 5 & $5.9 \times 10^{-13}$ & $1.1 \times 10^{-11}$ & $3.9 \times 10^{-12}$ & $4.2 \times 10^{-12}$ & 107.6 \\
\hline UE-3bl-U1 & & 18 & $8.4 \times 10^{-14}$ & $2.6 \times 10^{-11}$ & $5.4 \times 10^{-12}$ & $8.2 \times 10^{-12}$ & 150.1 \\
\hline
\end{tabular}


Table 3-4

Summary of Descriptive Statistics for Hydrologic Properties for Core and Drill Cuttings Samples from the U3ax/bl Exploratory Boreholes

\begin{tabular}{|c|c|c|c|c|c|c|c|}
\hline & \multirow{2}{*}{$\begin{array}{l}\text { Sample } \\
\text { ID }\end{array}$} & \multirow{2}{*}{$\begin{array}{c}\text { Number of } \\
\text { Samples }\end{array}$} & \multicolumn{2}{|c|}{ Range } & \multirow{2}{*}{ Mean } & \multirow{2}{*}{$\begin{array}{l}\text { Standard } \\
\text { Deviation }\end{array}$} & \multirow{2}{*}{$\begin{array}{l}\text { Coefficient } \\
\text { of Variation } \\
\text { (percent) }\end{array}$} \\
\hline & & & Minimum & Maximum & & & \\
\hline \multicolumn{8}{|c|}{ Saturated Hydraulic Conductivity (centimeters per second) } \\
\hline UE-3bl-D1 & \multirow{2}{*}{ DB1 } & 18 & $8.2 \times 10^{-5}$ & $2.5 \times 10^{-2}$ & $5.4 \times 10^{-3}$ & $8.0 \times 10^{-3}$ & 149.3 \\
\hline UE-3bl-U1 & & 19 & $1.2 \times 10^{-4}$ & $1.9 \times 10^{-2}$ & $3.4 \times 10^{-3}$ & $4.6 \times 10^{-3}$ & 134.6 \\
\hline \multicolumn{8}{|c|}{ Gravimetric Water Content (percent) } \\
\hline \multirow[t]{4}{*}{ UE-3bl-D1 } & DB1 & 21 & 4.2 & 11.6 & 7.6 & 1.8 & 23.6 \\
\hline & DRI1 & 16 & 4.4 & 11.1 & 7.7 & 1.6 & 20.5 \\
\hline & HGC & 18 & 3.8 & 11.2 & 7.7 & 1.8 & 24.1 \\
\hline & TOTAL & 55 & 3.8 & 11.6 & 7.6 & 1.7 & 22.5 \\
\hline \multirow[t]{4}{*}{ UE-3bl-U1 } & DB1 & 21 & 4.1 & 9.2 & 6.4 & 1.8 & 28.1 \\
\hline & DRI1 & 19 & 3.6 & 11.3 & 7.1 & 2.1 & 29.3 \\
\hline & HGC & 19 & 4.0 & 10.6 & 6.9 & 2.0 & 29.1 \\
\hline & TOTAL & 59 & 3.6 & 11.3 & 6.8 & 1.9 & 28.7 \\
\hline UE-3bl-D1 & \multirow{2}{*}{$\begin{array}{c}\text { Drill } \\
\text { Cuttings } \\
\text { Samples }\end{array}$} & 93 & 2.7 & 8.1 & 5.2 & 1.1 & 22.0 \\
\hline UE-3bl-U1 & & 95 & 2.9 & 10.2 & 5.1 & 1.2 & 22.7 \\
\hline \multicolumn{8}{|c|}{ Volumetric Water Content (percent) } \\
\hline \multirow[t]{4}{*}{ UE-3bl-D1 } & DB1 & 21 & 6.8 & 14.5 & 10.7 & 2.0 & 19.0 \\
\hline & DRI1 & 16 & 7.3 & 13.7 & 11.2 & 1.6 & 14.2 \\
\hline & HGC & 18 & 5.6 & 16.2 & 11.1 & 2.7 & 24.1 \\
\hline & TOTAL & 55 & 5.6 & 16.2 & 11.0 & 2.1 & 19.4 \\
\hline \multirow[t]{4}{*}{ UE-3bl-U1 } & DB1 & 21 & 6.7 & 13.7 & 9.3 & 2.3 & 24.9 \\
\hline & DRI1 & 19 & 6.1 & 14.4 & 10.6 & 2.6 & 24.6 \\
\hline & HGC & 19 & 5.9 & 15.8 & 10.3 & 3.0 & 29.1 \\
\hline & TOTAL & 59 & 5.9 & 15.8 & 10.0 & 2.6 & 26.4 \\
\hline \multicolumn{8}{|c|}{ Water Potential (bars) } \\
\hline UE-3bl-D1 & \multirow{2}{*}{ DRI1 } & 16 & -51.0 & -10.2 & -24.7 & 14.4 & 58.2 \\
\hline UE-3bl-U1 & & 19 & -61.6 & -9.5 & -27.8 & 16.9 & 60.6 \\
\hline \multicolumn{8}{|c|}{ Total Hydraulic Potential (bars) $^{a}$} \\
\hline UE-3bl-D1 & \multirow{2}{*}{ DRI1 } & 16 & -51.6 & -14.7 & -27.4 & 13.0 & 47.3 \\
\hline UE-3bl-U1 & & 19 & -61.9 & -14.4 & -29.7 & 15.6 & 52.3 \\
\hline
\end{tabular}

a Water potential and gravimetric potential (assuming 0 datum at ground surface) 
Table 3-5

Summary of Descriptive Statistics for Chemical Properties and Environmental Tracer Data for Core Samples and Drill Cuttings Samples from the U3ax/bl Exploratory Boreholes

\begin{tabular}{|c|c|c|c|c|c|c|c|c|}
\hline & & \multirow{2}{*}{$\begin{array}{c}\text { Sample } \\
\text { ID }\end{array}$} & \multirow{2}{*}{$\begin{array}{c}\text { Number } \\
\text { of } \\
\text { Samples }\end{array}$} & \multicolumn{2}{|c|}{ Range } & \multirow{2}{*}{ Mean } & \multirow{2}{*}{$\begin{array}{l}\text { Standard } \\
\text { Deviation }\end{array}$} & \multirow{2}{*}{$\begin{array}{c}\text { Coefficient } \\
\text { of Variation } \\
\text { (percent) }\end{array}$} \\
\hline & & & & Minimum & Maximum & & & \\
\hline \multicolumn{9}{|c|}{ Inorganic Carbon (percent) } \\
\hline UE-3bl-D1 & & \multirow{2}{*}{ DB2 } & 21 & 0.01 & 1.63 & 0.64 & 0.42 & 66.5 \\
\hline UE-3bl-U1 & & & 23 & 0.02 & 1.17 & 0.41 & 0.35 & 87.1 \\
\hline \multicolumn{9}{|c|}{ Cation Exchange Capacity (milliequivalents per 100 grams) } \\
\hline UE-3bl-D1 & & \multirow{2}{*}{ DB2 } & 21 & 15.8 & 29.4 & 20.2 & 3.1 & 15.5 \\
\hline UE-3bl-U1 & & & 23 & 11.5 & 23.4 & 15.1 & 3.2 & 21.5 \\
\hline \multicolumn{9}{|c|}{ Chloride in Dry Soil (parts per million) } \\
\hline UE-3bl-D1 & & \multirow{2}{*}{ HGC } & 18 & 0.53 & 5.22 & 1.33 & 1.19 & 89.7 \\
\hline UE-3bl-U1 & & & 19 & 0.55 & 29.63 & 3.47 & 6.94 & 199.9 \\
\hline \multicolumn{9}{|c|}{ Bromide in Dry Soil (parts per million) } \\
\hline UE-3bl-D1 & & \multirow{2}{*}{ HGC } & 18 & 0.007 & 0.037 & 0.019 & 0.008 & 42.5 \\
\hline UE-3bl-U1 & & & 19 & 0.006 & 0.818 & 0.099 & 0.244 & 244.9 \\
\hline \multicolumn{9}{|c|}{ Chloride-Bromide Ratio } \\
\hline UE-3bl-D1 & & \multirow{2}{*}{ HGC } & 18 & 47.0 & 141.0 & 66.0 & 26.8 & 40.6 \\
\hline UE-3bl-U1 & & & 19 & 7.0 & 152.0 & 95.5 & 33.1 & 34.7 \\
\hline \multicolumn{9}{|c|}{ Stable Isotopes (per mil) } \\
\hline \multirow{2}{*}{ UE-3bl-D1 } & $\delta \mathrm{D}$ & \multirow{4}{*}{ DRI3 } & 17 & -117.0 & -92.0 & -107.8 & 8.2 & 7.6 \\
\hline & $-\delta^{18} O$ & & 17 & -15.5 & -9.2 & -13.6 & 1.9 & 13.9 \\
\hline \multirow{2}{*}{ UE-3bl-U1 } & $\delta \mathrm{D}$ & & 15 & -113.0 & -92.0 & -102.7 & 7.2 & 7.0 \\
\hline & $-\delta^{18} O$ & & 15 & -15.4 & -9.4 & -12.7 & 2.0 & 15.9 \\
\hline \multicolumn{9}{|c|}{ Tritium (unenriched) (picoCuries per Liter) } \\
\hline $\begin{array}{l}\text { UE-3bl-D1 } \\
\text { (drill cutting }\end{array}$ & amples) & DRI2 & 8 & 760 & 9,240 & $3,843.9$ & $2,630.4$ & 68 \\
\hline $\begin{array}{l}\text { UE-3bl-D1 } \\
\text { (core samp }\end{array}$ & & \multirow{2}{*}{$\mathrm{ARCH}$} & 10 & 471 & 7,300 & $3,465.0$ & $2,346.8$ & 65 \\
\hline $\begin{array}{l}\text { UE-3bl-U1 } \\
\text { (core samp }\end{array}$ & & & 10 & $350^{\mathrm{a}}$ & 849 & 469.0 & 172.1 & 37 \\
\hline
\end{tabular}

a This value is the detection limit for the unenriched tritium analyses. 
Table 3-6

Summary of Unified Soil Classification System Assignments for Core Samples from the U3ax/bl Exploratory Boreholes

\begin{tabular}{||c||c|c|c|c|c||c||}
\hline \multirow{2}{*}{ Borehole } & \multicolumn{5}{|c||}{ Number and Percent () of Samples with Given USCS Group Names ${ }^{\text {a }}$} \\
\cline { 2 - 7 } & SW & SP & SW-SM & SP-SM & SM & Total \\
\hline \hline \multirow{2}{*}{ UE-3bl-D1 } & $\begin{array}{c}3 \\
(17 \%)\end{array}$ & $\begin{array}{c}1 \\
(6 \%)\end{array}$ & $\begin{array}{c}6 \\
(33 \%)\end{array}$ & $\begin{array}{c}1 \\
(6 \%)\end{array}$ & $\begin{array}{c}7 \\
(39 \%)\end{array}$ & 18 \\
\hline UE-3bl-U1 & $\begin{array}{c}6 \\
(32 \%)\end{array}$ & $\begin{array}{c}1 \\
(5 \%)\end{array}$ & $\begin{array}{c}7 \\
(37 \%)\end{array}$ & -- & $\begin{array}{c}5 \\
(26 \%)\end{array}$ & 519 \\
\hline \hline TOTAL & $\begin{array}{c}9 \\
(24 \%)\end{array}$ & $\begin{array}{c}2 \\
(5 \%)\end{array}$ & $\begin{array}{c}13 \\
(35 \%)\end{array}$ & $\begin{array}{c}1 \\
(3 \%)\end{array}$ & $\begin{array}{c}12 \\
(32 \%)\end{array}$ & $\begin{array}{c}37 \\
(99 \%)^{b}\end{array}$ \\
\hline
\end{tabular}

a USCS = Unified Soil Classification System

SW: $\quad$ Well graded sand ( $<5 \%$ silt) SP: $\quad$ Poorly graded sand $(<5 \%$ silt)

SW-SM: $\quad$ Well graded sand with silt (5 to $12 \%$ silt) SP-SM: Poorly graded sand with silt (5 to $12 \%$ silt)

SM: $\quad$ Silty sand (>12 \%silt)

-- $\quad$ No samples in this USCS group

b Total does not equal 100 percent due to rounding.

Table 3-7

Summary of Descriptive Statistics of Moisture Retention Curves for Core Samples from the U3ax/bl Exploratory Boreholes

\begin{tabular}{||l|l|c|c|c|c||}
\hline \multirow{2}{*}{ Borehole } & \multicolumn{1}{|c|}{ Statistic } & $\begin{array}{c}\theta_{\mathrm{r}} \\
(\text { percent })\end{array}$ & $\begin{array}{c}\theta_{\mathrm{s}} \\
(\text { percent })\end{array}$ & $\begin{array}{c}\alpha \\
\left(\mathrm{cm}^{-1}\right)\end{array}$ & $\mathbf{n}$ \\
\hline \begin{tabular}{|} 
Ue-3bl-D1 \\
$(\mathrm{s}=18)$
\end{tabular} & Minimum & 0.0 & 29.2 & 0.009 & 1.15 \\
\cline { 2 - 6 } & Maximum & 10.2 & 48.2 & 0.457 & 1.90 \\
\cline { 2 - 6 } & Mean & 7.6 & 39.9 & 0.065 & 1.47 \\
\cline { 2 - 6 } & Standard Deviation & 2.9 & 5.3 & 0.10 & 0.21 \\
\cline { 2 - 6 } & Coefficient of Variation (percent) & 38.2 & 13.3 & 153.8 & 14.3 \\
\hline \multirow{3}{*}{$\begin{array}{l}\text { UE-3bl-U1 } \\
\text { (S=10) }\end{array}$} & Minimum & 0.5 & 29.3 & 0.016 & 1.13 \\
\cline { 2 - 6 } & Maximum & 4.4 & 44.1 & 0.776 & 1.61 \\
\cline { 2 - 6 } & Mean & 2.0 & 37.9 & 0.159 & 1.29 \\
\cline { 2 - 6 } & Standard Deviation & 1.3 & 4.0 & 0.21 & 0.14 \\
\cline { 2 - 6 } & Coefficient of Variation (percent) & 65.0 & 10.6 & 132.1 & 10.9 \\
\hline
\end{tabular}

Where: $\quad \theta_{\mathrm{r}}$ is the residual volumetric water content $\left(\mathrm{cm}^{3} / \mathrm{cm}^{3}\right)$

$\theta_{\mathrm{s}}$ is the saturated volumetric water content $\left(\mathrm{cm}^{3} / \mathrm{cm}^{3}\right)$

$\alpha\left(\mathrm{cm}^{-1}\right)$ and $\mathrm{n}$ (dimensionless) are curve-fitting parameters

$\mathrm{s}$ is the number of samples 
Since each borehole was drilled at an approximate 45-degree angle, the borehole slant depth does not correspond to vertical depth below the ground surface. Unless specifically stated otherwise, borehole slant depths, rather than vertical depths, are presented in this report. The corresponding vertical depths for given borehole slant depths are given in Appendix D.

\subsection{General Geologic Description, Lithology, and Stratigraphy}

General geologic descriptions and qualitative lithologic and stratigraphic information are useful in describing the hydrogeologic conditions of the alluvium beneath the U3ax/bl disposal unit. The lithology of the alluvium can influence soil water movement. For example, the presence of a carbonate horizon would impede soil water movement.

\subsubsection{General Geologic, Lithologic, and Stratigraphic Data for Alluvium}

Visual geologic descriptions were made on both core and drill cuttings samples. These were recorded on borehole log sheets and drill cuttings log data sheets (Appendix B). These data sheets include a field description of lithology, cementation, particle shape, color, and texture. Preliminary soil texture classifications were determined via visual inspection in the field; final soil texture classifications were determined from sieve analyses (Section 3.4.1). Geologic descriptive information from both boreholes is summarized below.

The geologic samples from both boreholes consisted of unconsolidated alluvium. The field geologist, who examined all samples, estimated that the alluvial material consisted of 95 percent tuff fragments and 5 percent carbonate fragments. This estimate was based on visual inspection and is only an approximation. The degree of cementation in the samples ranged from weakly cemented to uncemented. This field assessment was based on visual inspection and the reaction of the samples to dilute hydrochloric acid, which ranged from no reaction to strong reaction. Thin layers (less than $5 \mathrm{~cm}$ [2 in.]) of secondary calcium carbonate were found in core samples from both boreholes. Gravel and coarse-grained sand particles were subangular to subrounded. Using the Munsell color chart, the most prevalent color was brown, ranging from very pale brown to yellowish brown.

The textural groups based on the Unified Soil Classification System (USCS) are summarized for alluvial core samples in Table 3-6. Laboratory results are presented in Appendix C. The textural group of all core samples ranged from a silty sand to a well-graded sand. The two most prevalent textural groups found in the samples from Borehole D1 were SW-SM (well-graded sand with silt) and SM (silty sand). In the samples from Borehole U1, the most prevalent groups 
were SW (well-graded sand), SW-SM (well-graded sand with silt), and SM (silty sand). The textural data are consistent with the findings of the archival literature search (REECo, 1994a).

\subsubsection{Inorganic Carbon}

Carbon concentration in the geologic samples might suggest the presence of a carbonate horizon, which could create a barrier to soil water movement. Depth profiles of inorganic carbon in core samples from boreholes U1 and D1 are shown in Figure 3-1. Tabular values of inorganic carbon measurements, as percent inorganic carbon, are listed in Appendix D. Descriptive statistics are given in Table 3-5.

Inorganic carbon concentrations in the core samples were low, with mean values less than 1 percent by weight. Borehole D1 had 5 (out of 18) core samples with values equal to or greater than 1 percent, and Borehole U1 had 2 (out of 19) core samples with values equal to or greater than 1 percent. For Borehole D1, the highest carbon value (1.63 percent) was found at a slant

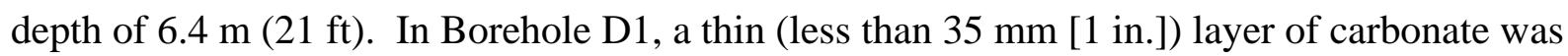
identified from field descriptions for the depth interval of 6.1 to $6.9 \mathrm{~m}$ (20.0 to $22.5 \mathrm{ft}$ ), which corresponds to the high inorganic carbon concentration for this interval. For Borehole U1, the

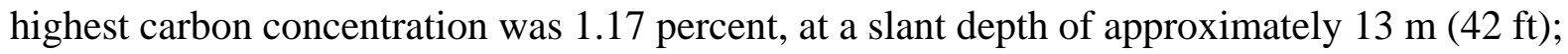
the gravel-sized particles at this depth were observed to be coated with carbonate. As is documented in Sections 3.5 and 3.6, no evidence was found that the thin carbonate layers or carbonate-coated particles influenced the hydrogeologic properties or conditions of the alluvium.

\subsection{Physical and Chemical Properties}

Core samples were analyzed for several physical properties (particle size distribution, dry bulk density, particle density, and porosity) and one chemical property, CEC. Bulk density and porosity measurements are dependent on the arrangement and packing of unconsolidated alluvial particles, and therefore were made only on intact core segments. Cation-exchange capacity tests were done on either intact or non-intact core segments, as CEC is much more dependent on soil texture than on soil structure (arrangement and packing). Particle size distribution analyses were done only after all other analyses had been completed, since particle size distribution analysis destroys the soil structure of the sample.

\subsubsection{Particle Size Distribution}

Particle size distribution analyses were completed on all DB1 core segments using a dry sieve method. DBS\&A determined that 8 of the 18 core segments from Borehole D1, and 6 of 19 core 


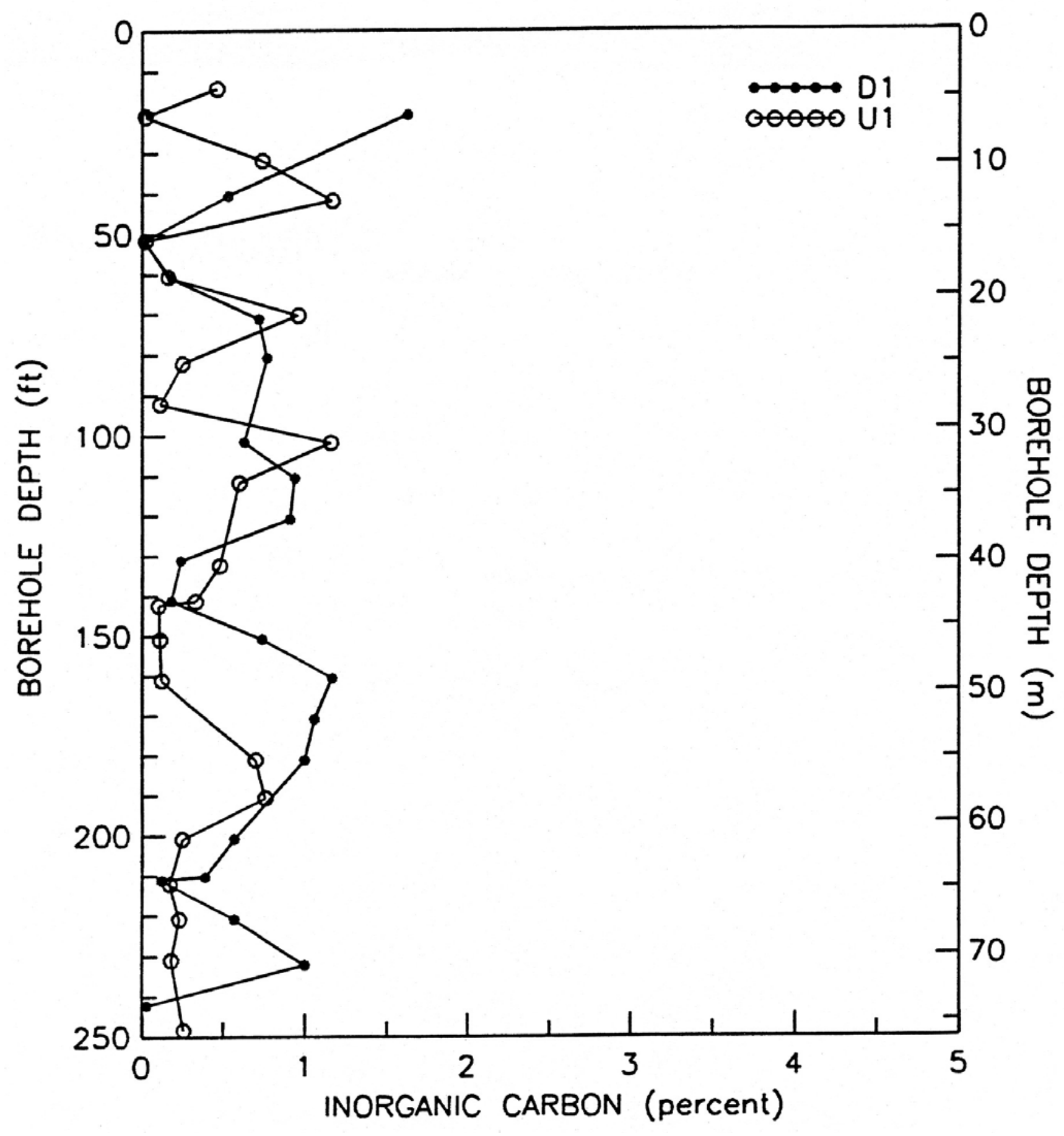

Figure 3-1

Slant Depth Profiles of Inorganic Carbon for Core Samples from the U3ax/bl Exploratory Boreholes 
segments from Borehole U1 required wet sieve analysis for the fine fraction (silt/clay size fraction) because of the large amount of fine material in these samples.

The results of particle size distribution analyses are presented in tabular form in Appendix C. Data from the Number (No.) 4 and No. 200 sieve screens (percent of material passing) for alluvial core samples are plotted versus depth in Figures 3-2 and 3-3. These two sieve screen sizes are chosen for plotting because material within these two screen sizes is designated as sand. Material that does not pass through the No. 4 sieve is classified as gravel, and material passing through the No. 200 sieve is designated as fines (i.e., the silt and clay size fraction).

Based on the USCS, all core samples collected from both boreholes are classified as sand. However, a comparison of Figures 3-2 and 3-3 reveals slight differences in the particle size distribution between the two boreholes. The core samples from Borehole D1 appear to have a higher silt/clay content and lower gravel content than samples from Borehole U1. For example, six sampled intervals from Borehole D1 had a silt/clay content greater than any interval from Borehole U1, and five sampled intervals from Borehole U1 had a gravel content greater than any interval from Borehole D1. Such variability is common in alluvial deposits.

No trend with depth in particle size distribution was evident in either borehole (in this report, the word "trend" refers to drift in mean, and not in standard deviation or other statistical properties). Descriptive statistics of the No. 4 and No. 200 sieve screen data for core samples from both boreholes are given in Table 3-3.

\subsubsection{Bulk Density, Particle Density, and Porosity}

For each borehole, dry bulk density was determined on the DB1 and DRI1 core segments from each core run. These data are listed in tabular form in Appendix C. Descriptive statistics for bulk density, as well as particle density and porosity, are presented in Table 3-3. Plots of bulk density versus depth for boreholes D1 and U1 are shown in Figures 3-4 and 3-5, respectively.

Figures 3-4 and 3-5 show little variability in the bulk density between the DB1 and DRI1 core segments from both boreholes, except Run No. 23 in Borehole D1 (Figure 3-4), taken at a slant depth of approximately $70 \mathrm{~m}(230 \mathrm{ft})$. In this core run, the DRI bulk density value was 1.16 grams per cubic centimeter $\left(\mathrm{g} / \mathrm{cm}^{3}\right)$ and the DB1 value was $1.55 \mathrm{~g} / \mathrm{cm}^{3}$. A bulk density of $1.16 \mathrm{~g} / \mathrm{cm}^{3}$ is significantly lower than the bulk density values associated with the other samples from both boreholes. 


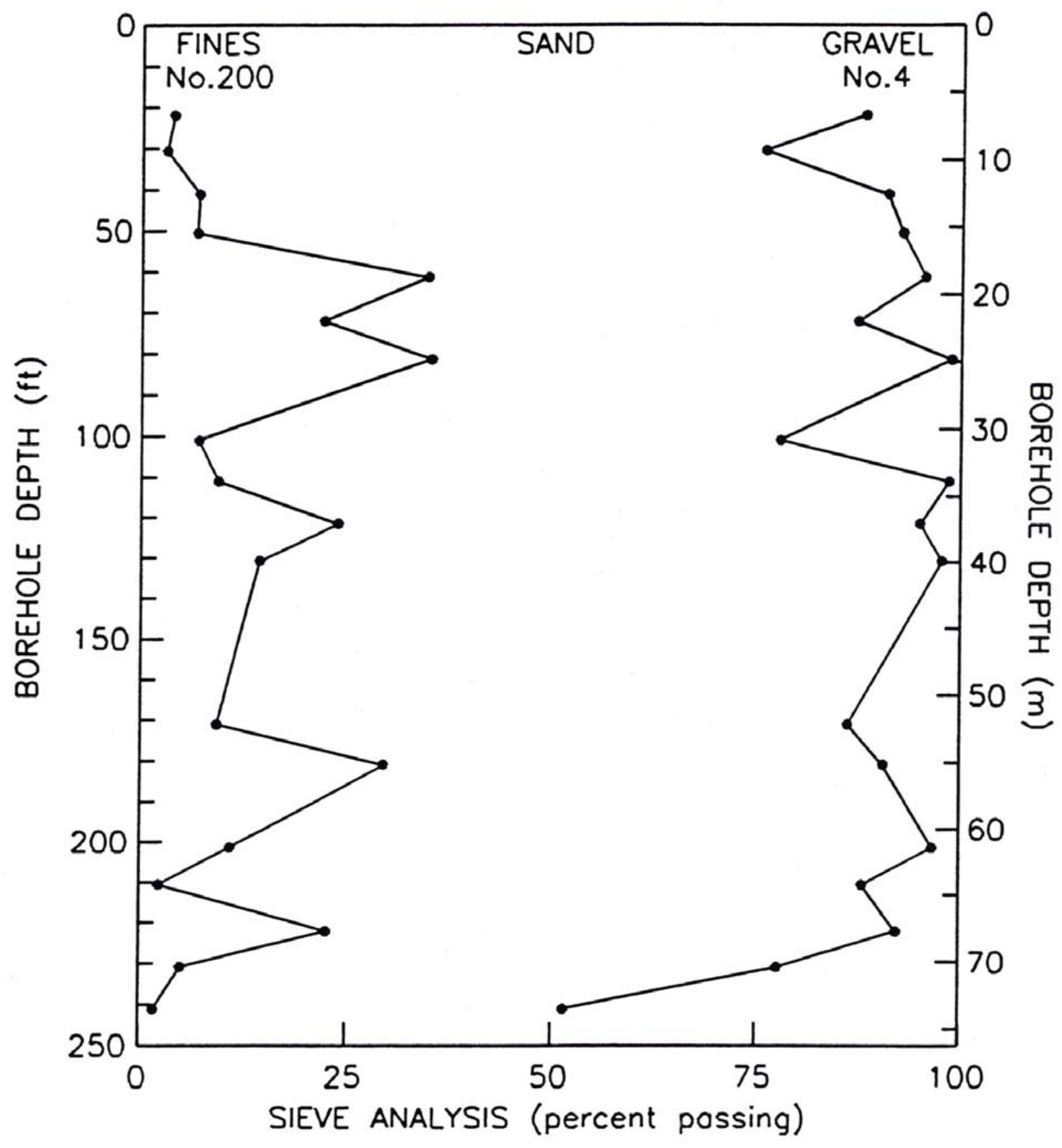

Figure 3-2

Slant-Depth Profiles of Dry Sieve Analyses for Core Samples from UE-3bl-D1 (percent passing No. 4 and No. 200 Mesh Screens) 


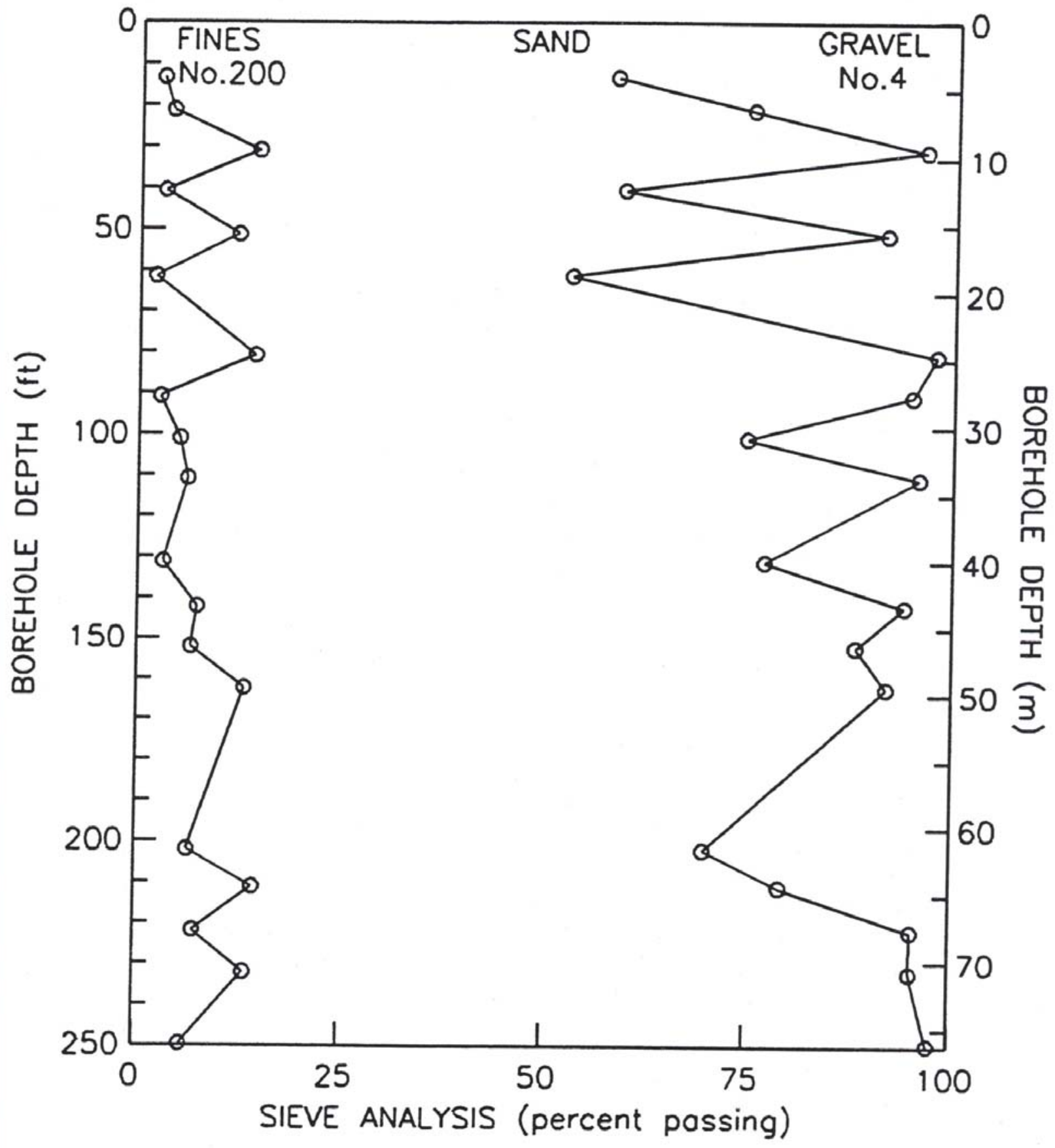

Figure 3-3

Slant-Depth Profiles of Dry Sieve Analyses for Core Samples from UE-3bl-U1 (percent passing No. 4 and No. 200 Mesh Screens) 


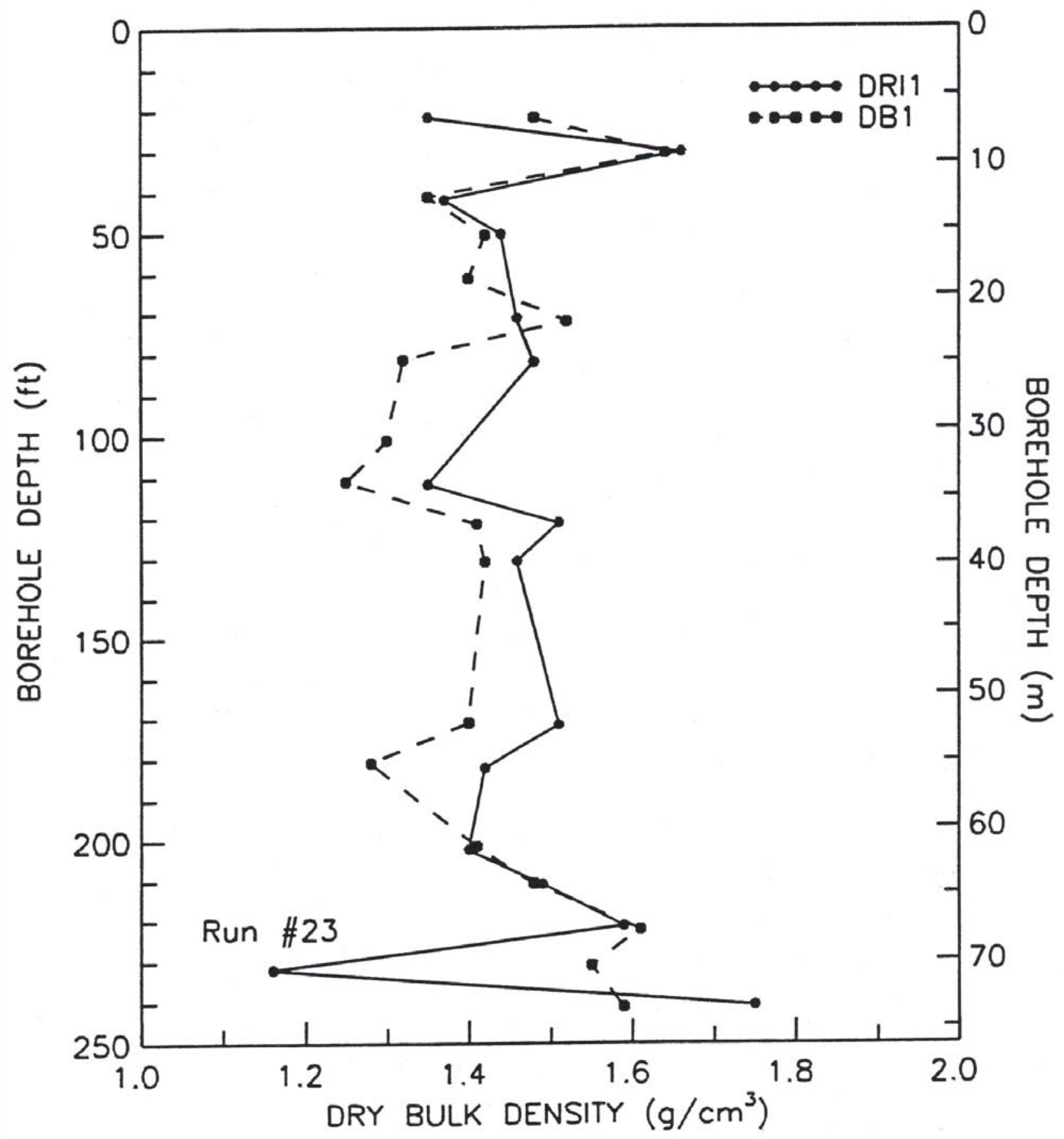

Figure 3-4

Slant-Depth Profiles of Dry Bulk Density for Core Samples from UE-3bl-D1 (in grams per cubic centimeter) 


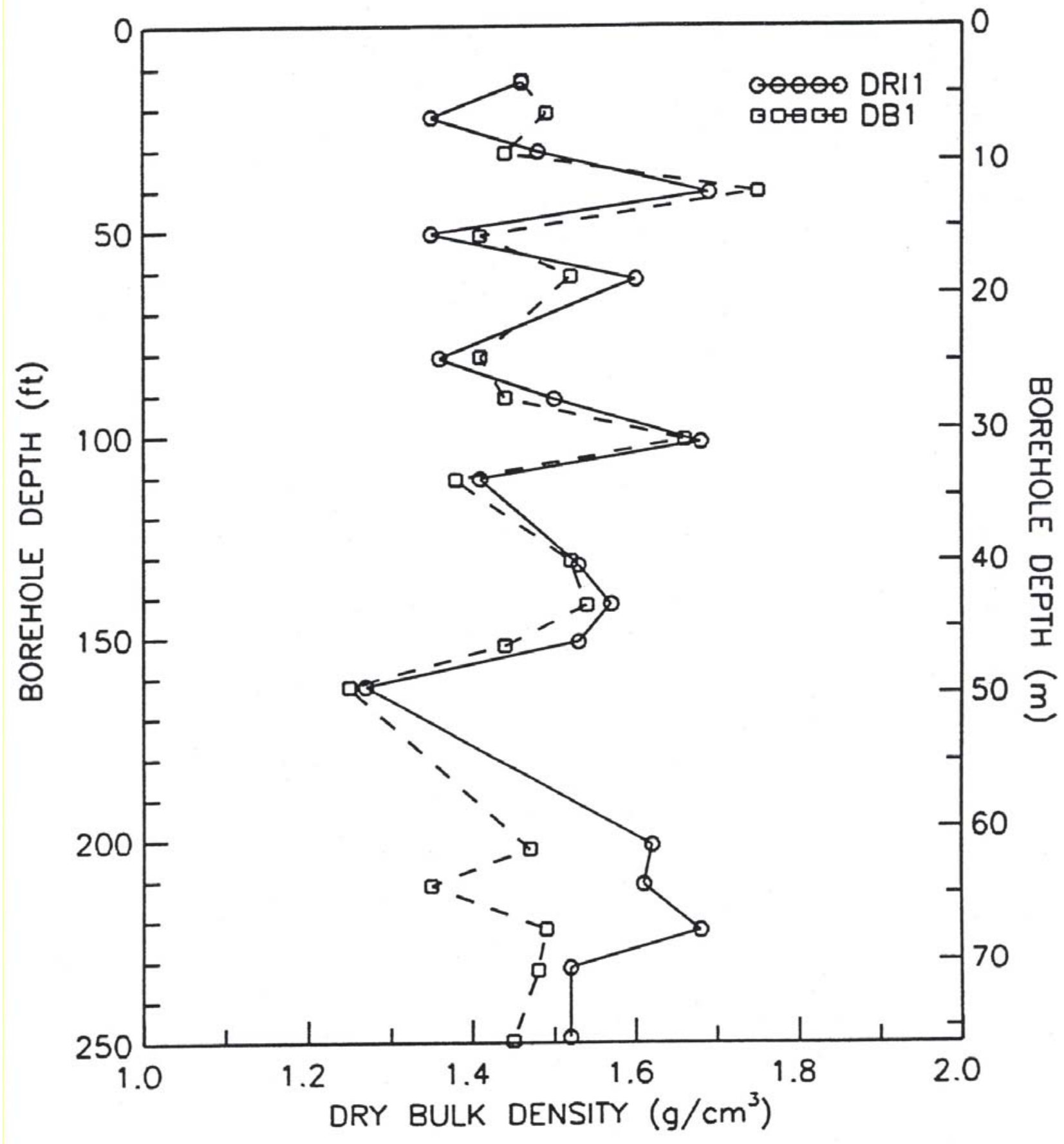

Figure 3-5

Slant-Depth Profiles of Dry Bulk Density for Core Samples from UE-3bl-U1 (in grams per cubic centimeter) 
If the small value $\left(1.16 \mathrm{~g} / \mathrm{cm}^{3}\right)$ reflected in-situ conditions, it is likely that the value of the next sample would also have been small. However, the bulk density values for the DB1 and DRI1 core segments of the next core run, taken at a slant depth of approximately $73 \mathrm{~m}(240 \mathrm{ft})$ are

1.75 and $1.59 \mathrm{~g} / \mathrm{cm}^{3}$, respectively; both are above the overall mean value of $1.45 \mathrm{~g} / \mathrm{cm}^{3}$. The occurrence of an isolated unusual data point, with surrounding data points not reflecting the same conditions, is consistent with the hypothesis that something happened during sampling, handling, or shipping that affected the bulk density of that DRI core segment. Hence, the bulk density observed in Run No. 23 is thought to be an artifact, not representing in-situ conditions.

For both boreholes, no consistent trends with depth were found in bulk density. This is similar to the bulk density data obtained from nearby boreholes (REECo, 1994a). No significant differences in bulk density values were apparent between the two boreholes (Figure 3-6).

Particle density was determined on all DB1 core segments. These data are presented in tabular form in Appendix C. Plots of particle density versus depth are shown in Figure 3-7. Figure 3-7 illustrates the small variation of the particle density of the alluvial materials with depth, and the similarity of particle density values between the two boreholes. The observed particle densities are, as expected, consistent with values obtained from nearby boreholes (REECo, 1994a).

Estimates of porosity with depth were calculated (by definition) from the DB1 dry bulk density for a specific depth and the average particle density for each borehole. These data are presented in Appendix C. As with the bulk density values, outliers in the porosity values may reflect sampling disturbance rather than in-situ conditions. In addition, water-saturated porosity was measured on the DB1 core segments after the saturated hydraulic conductivity measurement was conducted on the same core segment (Section 3.5.1). Both calculated and water-saturated porosity values are plotted versus depth for boreholes U1 and D1 in Figures 3-8 and 3-9, respectively.

\subsubsection{Cation-Exchange Capacity}

Cation-exchange capacity is the amount of exchangeable cations that a soil can adsorb, expressed in milliequivalents per 100 grams of soil. Most cation exchange in soil occurs on the clay fraction because this size fraction has the largest surface area and the most reactive surfaces. Silt and sand particles can contribute to the CEC, but their contribution is generally insignificant when compared to that of the clay fraction. The CEC could influence the movement of contaminants (e.g., lead, cesium, and strontium) (Drever, 1988) disposed in the U3ax/bl disposal 


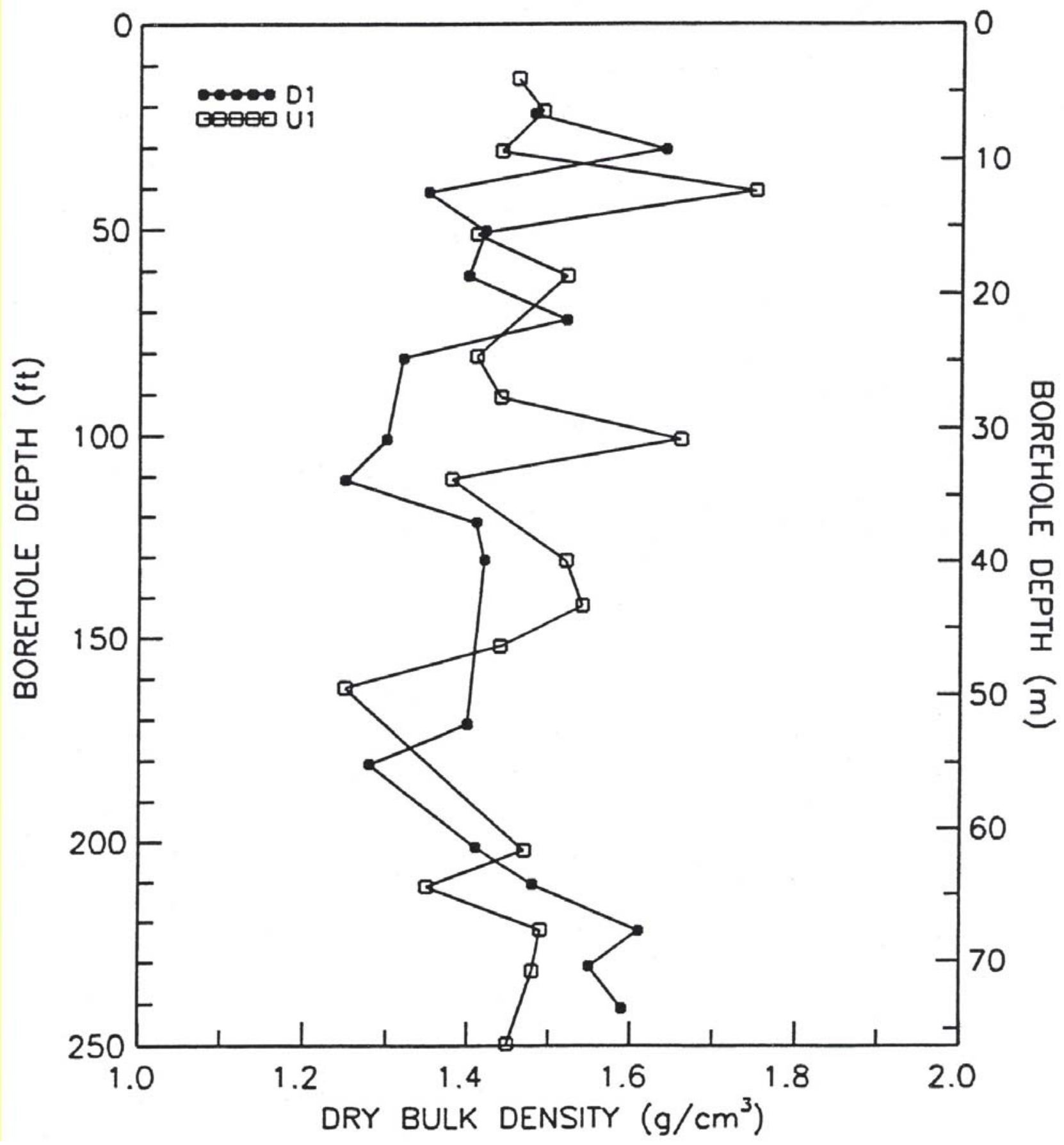

Figure 3-6

Slant-Depth Profiles of Dry Bulk Density for DB1 Core Samples from the U3ax/3bl Exploratory Boreholes (in grams per cubic centimeter) 


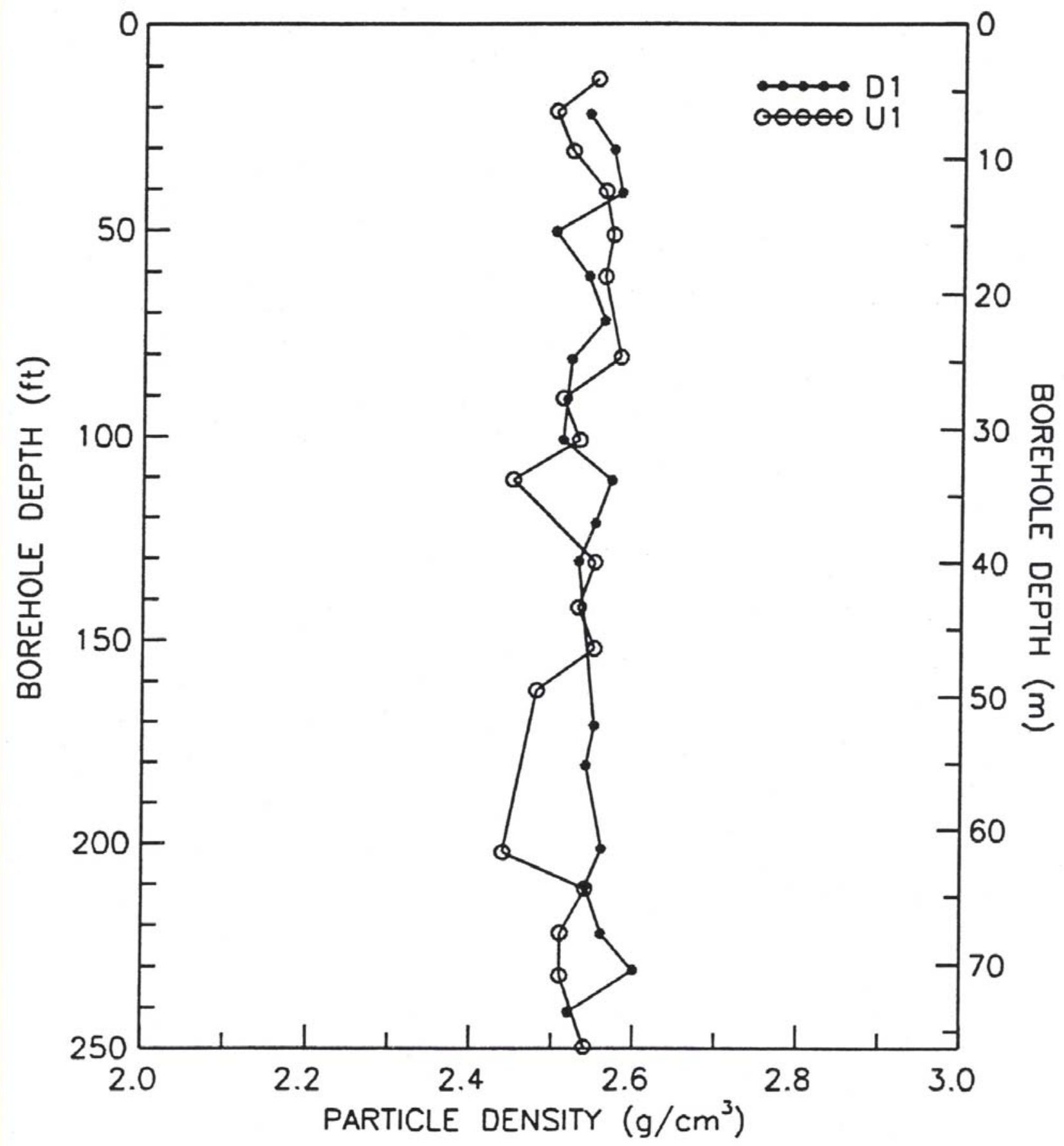

Figure 3-7

Slant-Depth Profiles of Particle Density for Core Samples from UE-3bl-D1 (in grams per cubic centimeter) 


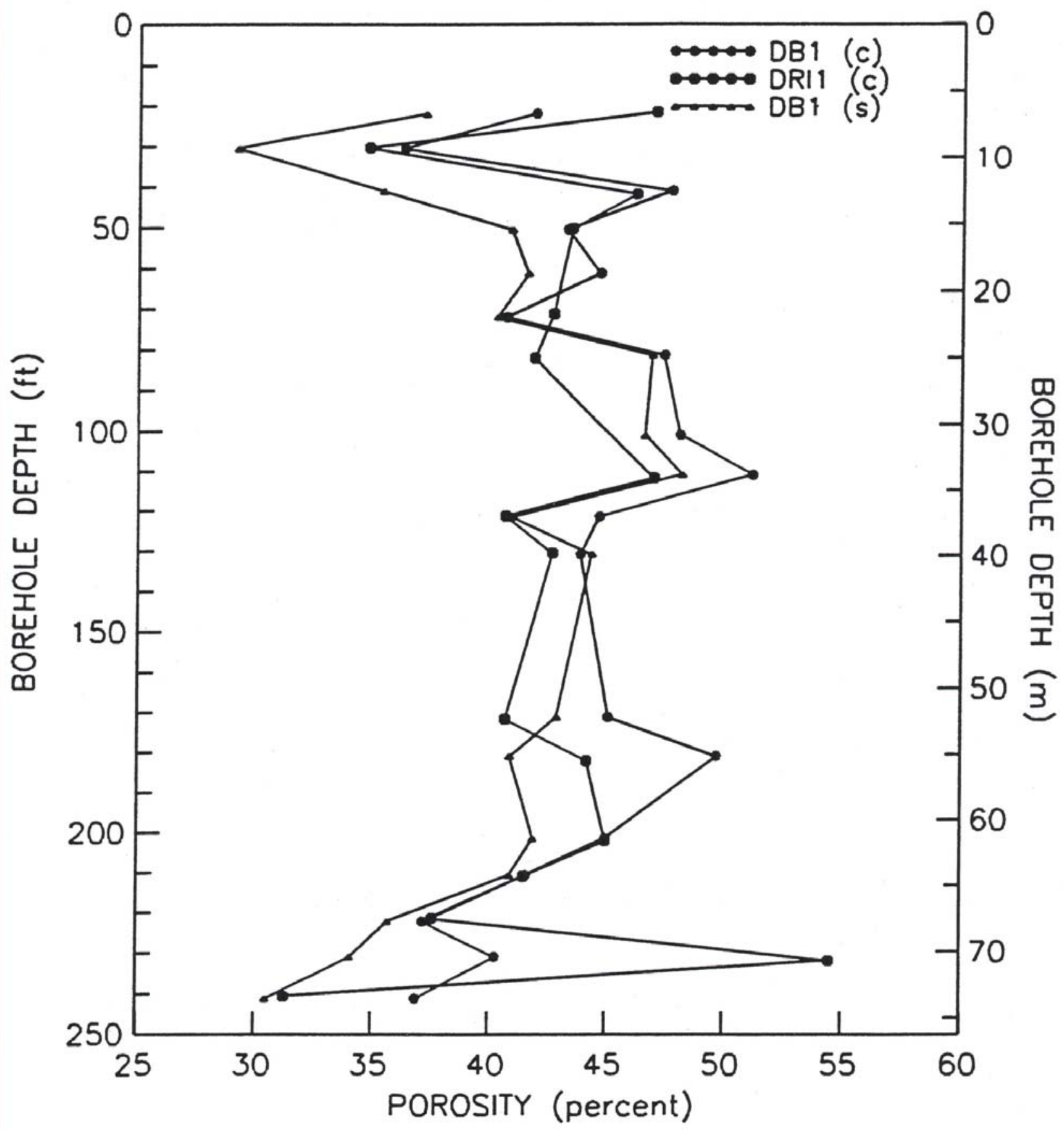

Figure 3-8

Slant-Depth Profiles of Calculated (c) and Water-Saturated (s) Porosity for Core Samples from UE-3bI-D1 


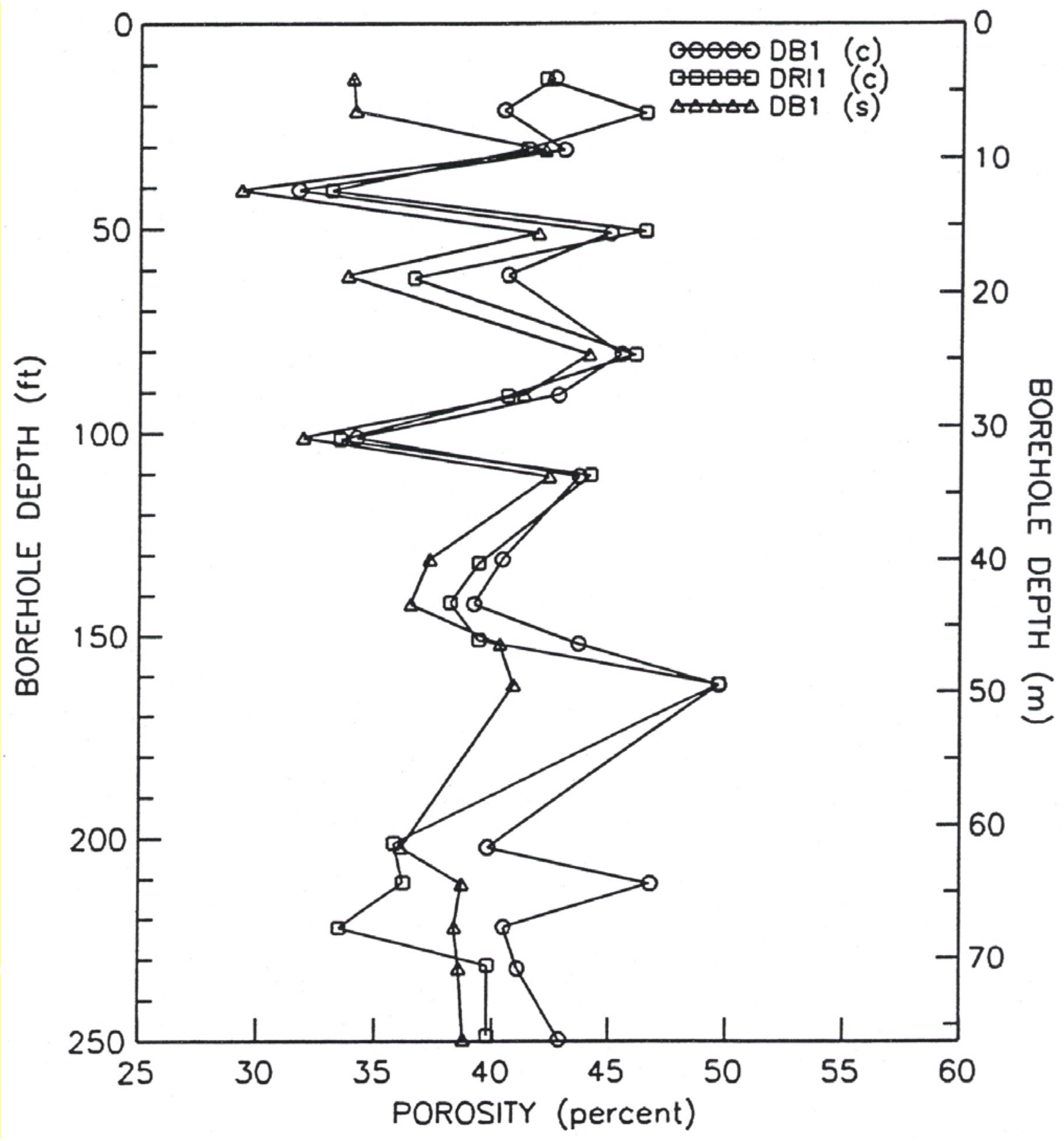

Figure 3-9

Slant-Depth Profiles of Calculated (c) and Water-Saturated (s) Porosity for Core Samples from UE-3bI-U1 
unit, were any leachate generated. Inorganic hazardous and radiological contaminants are often present as cations. A soil with a high CEC will generally have a greater ability to retard these contaminants than that of a soil with a low CEC.

Cation-exchange capacity values were determined on the DB2 core segments using a sodium acetate method (Table 3-1). CEC data for both boreholes are presented in tabular form in Appendix C. Figure 3-10 contains a plot of CEC versus depth for both boreholes. Descriptive statistics for CEC are given in Table 3-5. The mean CEC value for the samples from Borehole D1 was about one-third greater than the mean value for the samples from Borehole U1. This suggests that the clay content is higher in the samples from Borehole D1. This result supports the conclusion, drawn from the particle size distribution data, that the silt/clay fraction is higher in samples from Borehole D1 than the samples from Borehole U1.

\subsection{Hydrogeologic Properties}

Hydrogeologic property measurements include saturated hydraulic conductivity and moisture retention curves. For this study, unsaturated hydraulic conductivity values were calculated from these properties. Direct methods of measuring unsaturated hydraulic conductivity were not used because these measurements are difficult to obtain, in either the laboratory or in situ, at the very low water content conditions (Section 3.6.1) found in the vadose zone beneath the Area 3 RWMS.

\subsubsection{Saturated Hydraulic Conductivity}

Saturated hydraulic conductivity measurements were conducted on all DB1 core segments. The measurements were made using a constant head permeameter. Saturated hydraulic conductivity profiles are presented in Figure 3-11, and descriptive statistics are summarized in Table 3-4.

Data are provided in tabular form in Appendix C. No trends with depth in the values from either borehole are apparent (where "trend" indicates trend in mean and not in other statistical properties). Although slight differences in particle size distribution were noted, differences in saturated hydraulic conductivity between the two boreholes were minor to negligible, considering the large natural variability of saturated hydraulic conductivity. Hydraulic conductivity values observed are typical of the values Freeze and Cherry (1979) report for sand. 


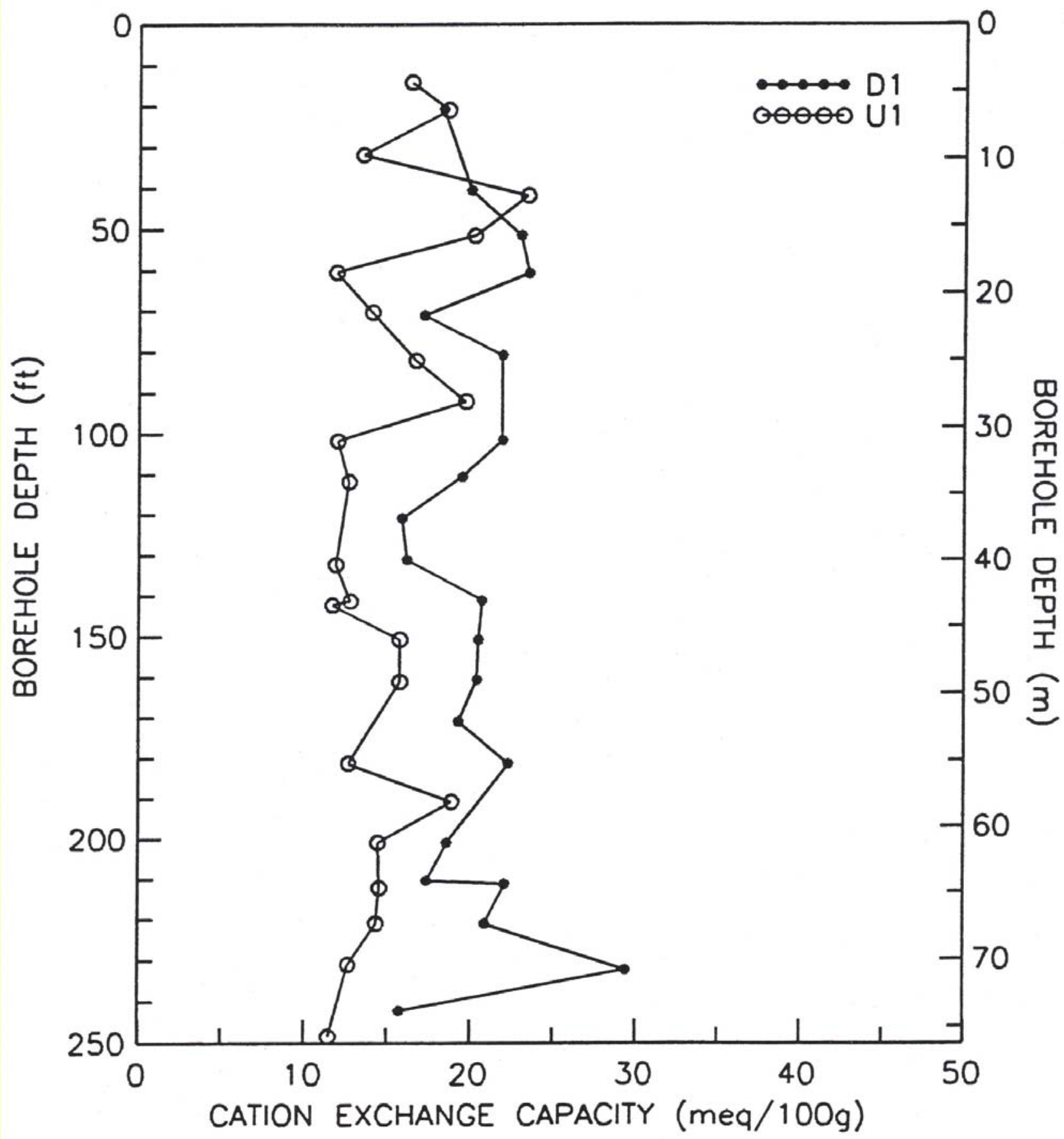

Figure 3-10

Slant-Depth Profiles of Cation-Exchange Capacity for Core Samples from the U3ax/3bl Exploratory Boreholes (in milliequivalents per 100 grams of soil) 


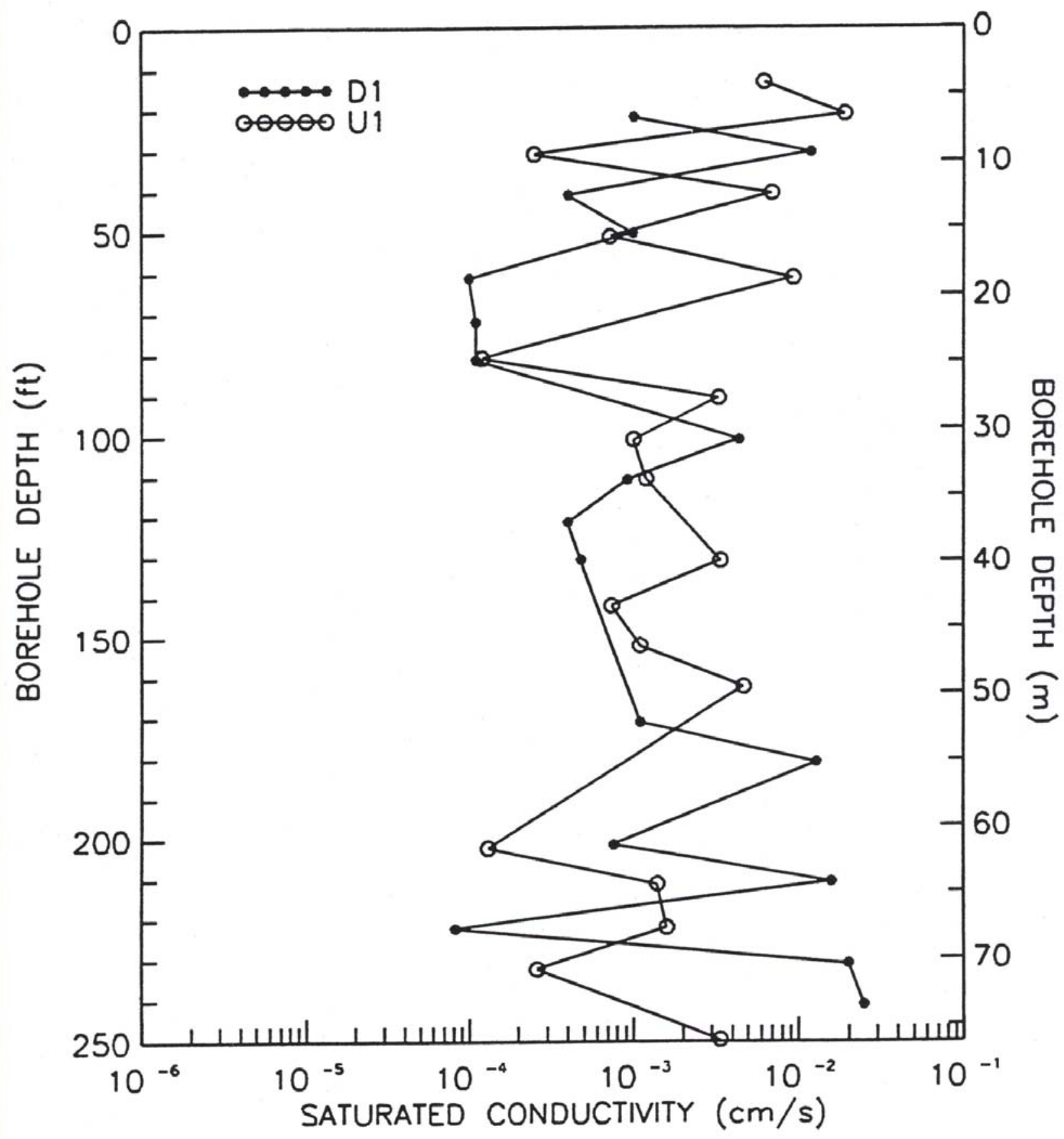

Figure 3-11

Slant-Depth Profiles of Saturated Hydraulic Conductivity for Core Samples from the U3ax/3bl Exploratory Boreholes (in centimeters per second) 
Saturated hydraulic conductivity depends on the porous medium and fluid. The parameter describing the porous medium is known as permeability. The relationship between saturated hydraulic conductivity and permeability is described by the following equation (Freeze and Cherry, 1979):

$$
K=(k \rho g) / \mu
$$

where $K$ is the hydraulic conductivity, $k$ is the intrinsic permeability of the porous medium, $\rho$ is the density of the fluid, $g$ is the acceleration due to gravity, and $\mu$ is the viscosity of the fluid. Since the density and viscosity of water are known, the permeability of the core can be calculated from the saturated hydraulic conductivity values. Descriptive statistics and tabular data for permeability are given in Table 3-3 and Appendix C, respectively. These calculated permeability values were compared to the effective permeability values determined from air permeability tests on selected core samples. This comparison is discussed in Section 3.7.

\subsubsection{Moisture Retention Relations}

Following saturated hydraulic conductivity measurements, moisture retention measurements were made on DB1 core segments from both boreholes. These measurements provide a relationship between water potential and water content at equilibrium (water potential and water content are constant with time) for a given soil water condition. The relationship between water potential and water content, as soil water conditions vary from near saturation to air-dried, can be described with a moisture retention relation. A minimum of eight points was measured for each core sample, so that a moisture retention curve could be developed. For each core segment, a moisture retention curve was fitted to the data using the method of van Genuchten (1978, 1980). The moisture retention relation is:

$$
\theta=\theta_{\mathrm{r}}+\left(\theta_{\mathrm{s}}-\theta_{\mathrm{r}}\right)\left[1+(-\alpha \mathrm{h})^{\mathrm{n}}\right]^{-\mathrm{m}}
$$

where $\theta$ is volumetric water content $\left(\mathrm{cm}^{3} / \mathrm{cm}^{3}\right), \theta_{\mathrm{s}}$ is the saturated volumetric water content $\left(\mathrm{cm}^{3} / \mathrm{cm}^{3}\right), \theta_{\mathrm{r}}$ is the residual volumetric water content $\left(\mathrm{cm}^{3} / \mathrm{cm}^{3}\right)$, h is matric potential $(\mathrm{cm}), \alpha$ $\left(\mathrm{cm}^{-1}\right)$ and $\mathrm{n}$ (dimensionless) are curve fitting parameters, and $\mathrm{m}$ equals (1-1/n). A nonlinear least squares computer code was used to calculate the curve-fitting parameters $\alpha$, n, and $\theta_{\mathrm{r}}$ (van Genuchten, 1978, 1980). These parameters for core samples are tabulated in Appendix C, and summary descriptive statistics are given in Table 3-6. Observed values of $\alpha$ from both boreholes are consistent with values calculated for coarse-grained materials (REECo,1995; BN, 2005a). 
The moisture retention curves for core segments from each borehole are shown in Figures 3-12 and 3-13. Tabular data are listed in Appendix C. Core interval depths are not identified in Figures 3-12 and 3-13. The curves from Borehole D1 did not extend into drier soil water conditions, as did the curves from Borehole U1, because air-dried measurements were not performed on the samples from Borehole D1.

In the laboratory analysis reports, DBS\&A stated that the moisture retention relations of the samples at low water potentials were typical of coarse-textured materials. However, the observed continued release of water at middle and high water potentials is not typical of a coarse-textured material. DBS\&A suggest that this atypical relation results from the presence of porous tuff clasts, which provide more water storage than the particle size distribution alone would predict.

\subsubsection{Unsaturated Hydraulic Conductivity}

Unsaturated hydraulic conductivity was calculated from moisture retention data and saturated hydraulic conductivity values using a method described by van Genuchten $(1978,1980)$. Water content is the amount of liquid water in a specified mass or volume of soil, and total hydraulic potential is the total energy of the soil water at a specific point in the soil. In van Genuchten's method, water content is expressed as the effective saturation, $\mathrm{S}$, which is a dimensionless water content defined by:

$$
\mathrm{S}=\left(\theta-\theta_{\mathrm{r}}\right)\left(\theta_{\mathrm{s}}-\theta_{\mathrm{r}}\right)^{-1}
$$

where $\theta, \theta_{\mathrm{s}}$, and $\theta_{\mathrm{r}}$ are as in Equation 2 . Unsaturated hydraulic conductivity, $\mathrm{K}(\mathrm{S})$, is derived by substituting the van Genuchten moisture retention curve-fitting parameters into the Mualem (1976) model for predicting K(S) to obtain:

$$
K(S)-K_{s} S^{1 / 2}\left[1-\left(1-S^{1 / m}\right)^{m}\right]^{2}
$$

where $\mathrm{K}_{\mathrm{s}}$ is the saturated hydraulic conductivity and $\mathrm{m}$ is as in Equation 2.

The resulting K(S) data, shown in Figures 3-14 and 3-15, is expressed as a function of $\theta$ and $\mathrm{K}(\theta)$, using Equation 3. The parameters required to calculate unsaturated hydraulic conductivity values for core samples are summarized in Appendix C. The plots in Figures 3-14 and 3-15 show unsaturated hydraulic conductivity decreasing steeply with decreasing water content. 


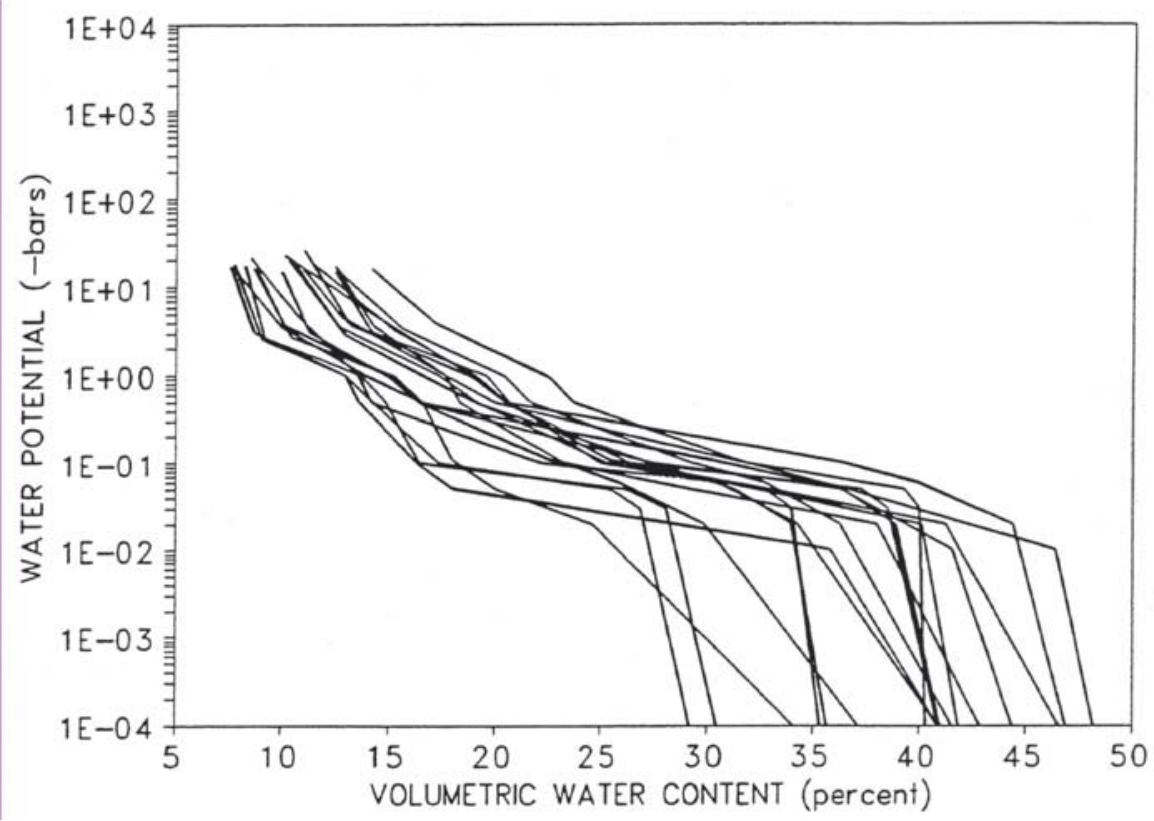

Figure 3-12

Composite Moisture Retention Curve Data for Core Samples from UE-3bI-D1

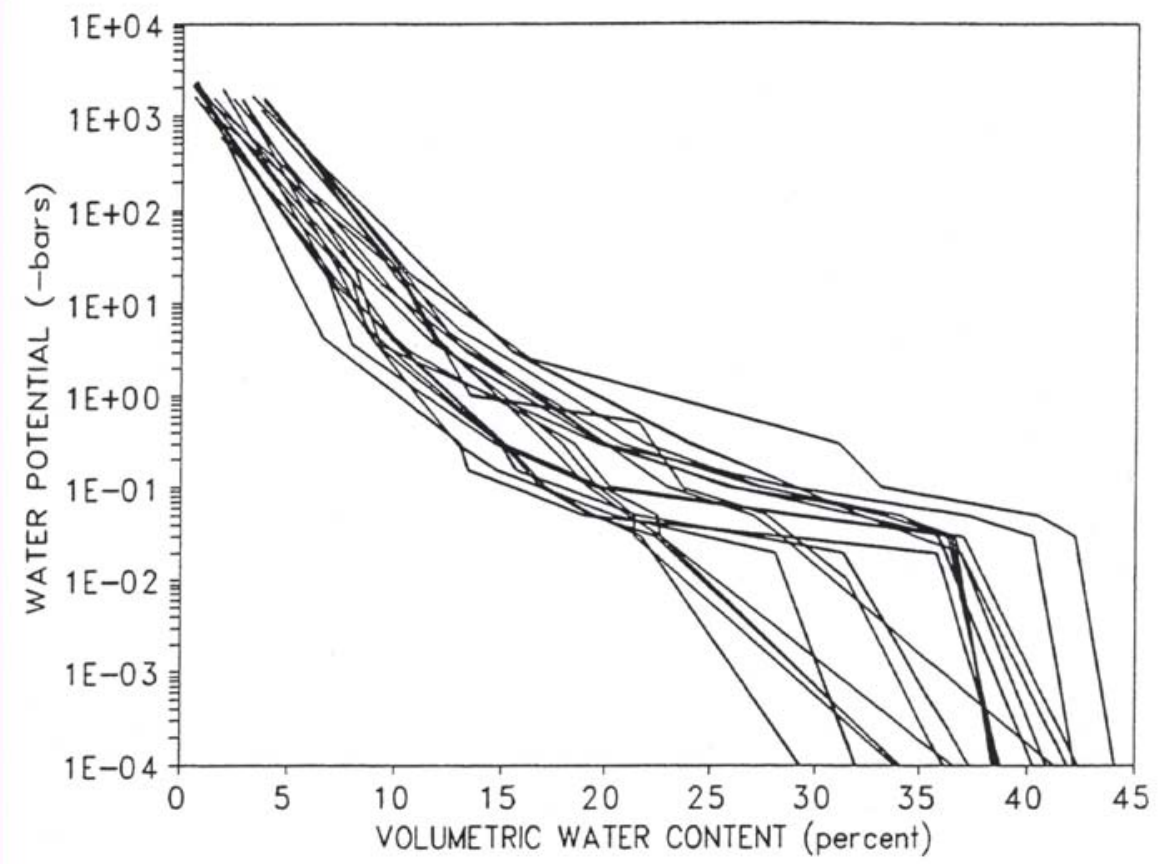

Figure 3-13

Composite Moisture Retention Curve Data for Core Samples from UE-3bl-U1 


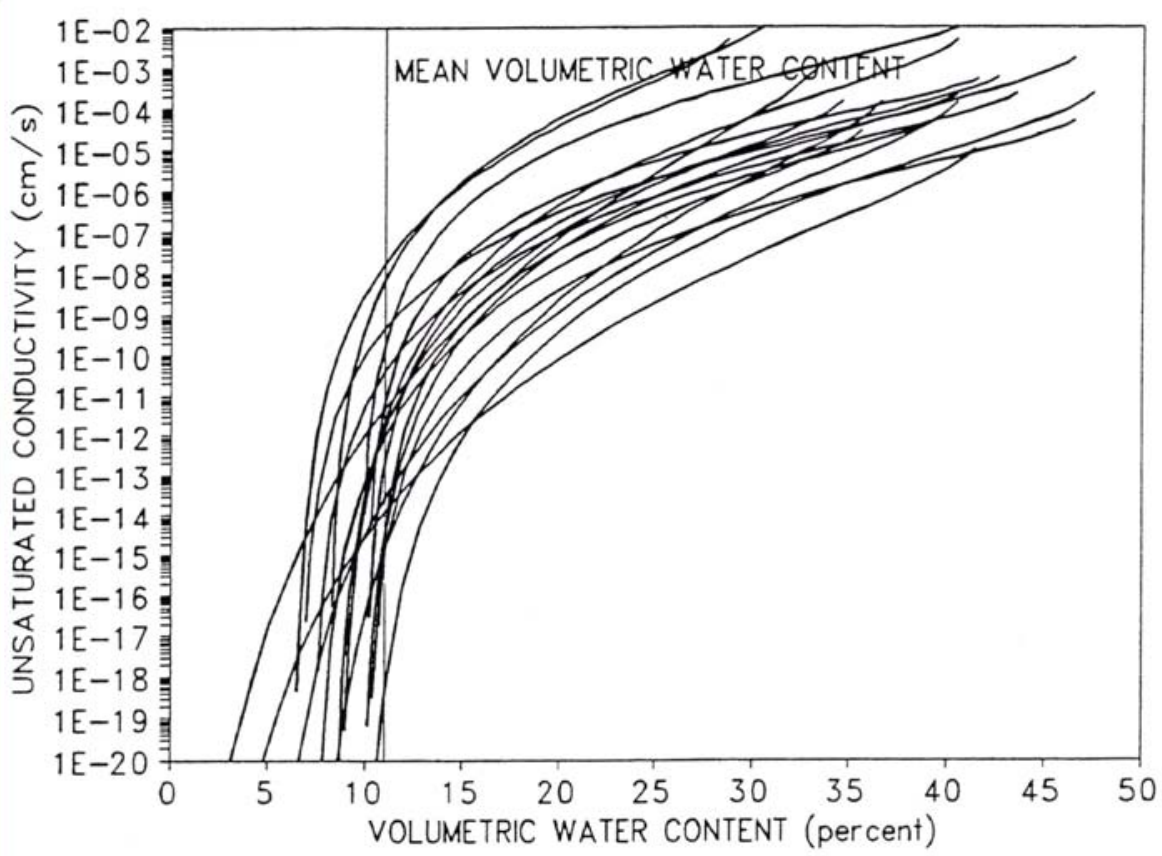

Figure 3-14

Fitted Unsaturated Hydraulic Conductivity Functions For Core Samples from UE-3bl-D1

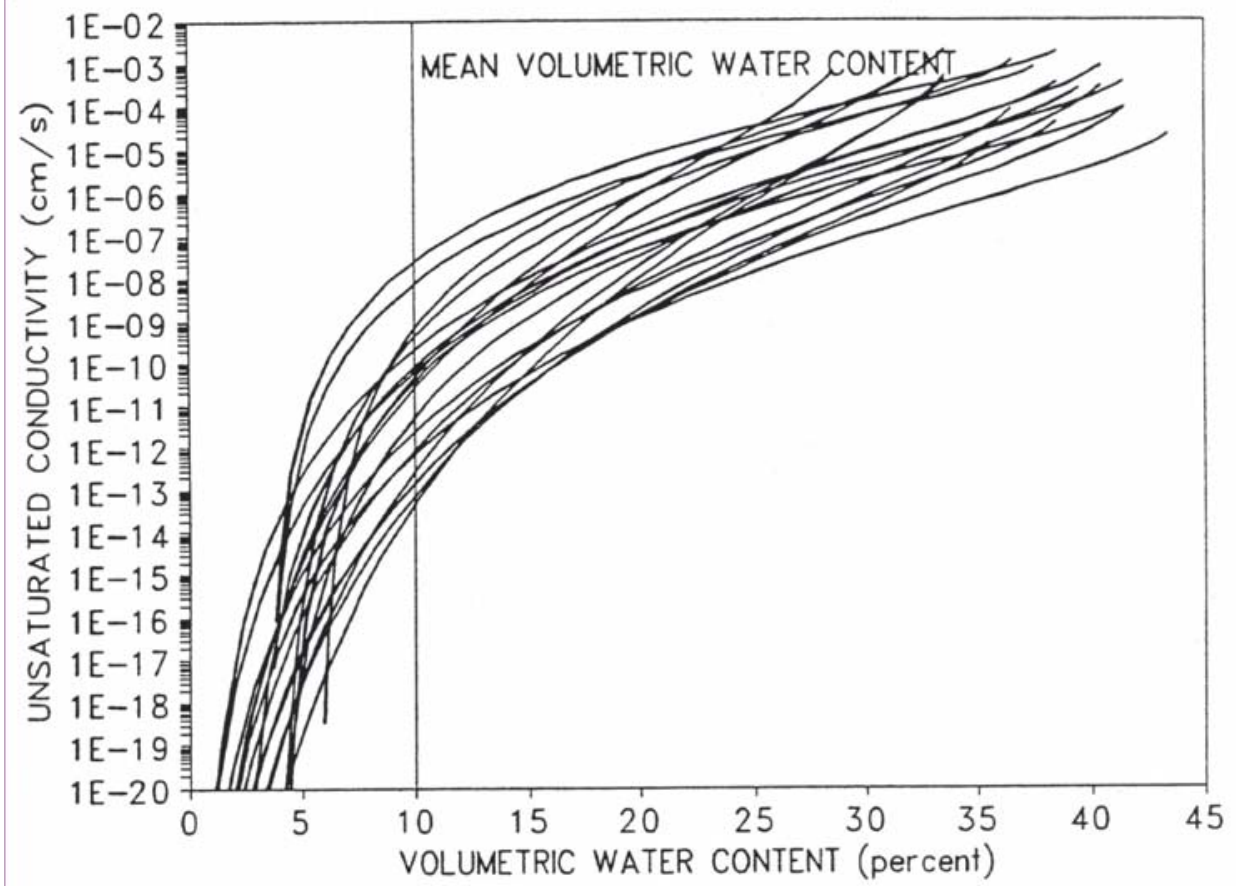

Figure 3-15

Fitted Unsaturated Hydraulic Conductivity Functions For Core Samples from UE-3bl-U1 
The vertical line on each plot represents the mean volumetric water content (Table 3-5) of all core segments from that borehole. The unsaturated hydraulic conductivity values at the mean water content of both boreholes are several orders of magnitude less than saturated hydraulic conductivity values.

\subsection{Hydrogeologic Conditions}

Hydrogeologic conditions are described using parameters, such as water content and total hydraulic potential, that can vary with time. The driving force for soil water movement is the difference in the total hydraulic potential between two points divided by the distance separating these points, which is called the total hydraulic gradient.

\subsubsection{Water Content}

The gravimetric water content, which is the ratio of the mass of water in a sample to the mass of the oven-dried soil sample, was determined for both drill cuttings and core samples. Volumetric water content, which is the ratio of the mass of water to the volume of soil, was determined for core samples. Volumetric water content was calculated by multiplying the gravimetric water content of a sample by its bulk density. Depending on core recovery, water content was measured in as many as three core segments (DB1, DRI1, and HGC) within a core run. The volumetric water content for each DB1 and DRI1 core segment was calculated using the bulk density value measured for each segment. The bulk density was not measured for the HGC core segments, so the volumetric water content for these core segments was calculated using the mean bulk density value of all DB1 and DRI1 core segments within the same borehole.

In addition, gravimetric water content was measured by REECo SPS personnel on archive core segments (3 from Borehole D1 and 2 from Borehole U1), and the data reported as DB1 samples. The archive core segments that were used to supplement the DB1 samples are identified in Appendix C. These samples were measured to fill data gaps resulting from poor core recovery at these depths. The volumetric water content values of the archive samples were calculated using the mean bulk density (including all core segments) for each borehole. The gravimetric and volumetric water content data from the two boreholes are listed in tabular form in Appendix C. Descriptive statistics for water content for drill cuttings and core samples are given in Table 3-5.

The mean gravimetric water content of drill cuttings samples from Borehole D1 was approximately 2.5 percent less than that for core samples. For Borehole U1, the mean gravimetric water content of drill cuttings samples was approximately 1.5 percent less than that 
for core samples. This is thought to result from the drying of cuttings by the compressed air as it lifted the cuttings from the borehole.

Volumetric water content profiles for boreholes D1 and U1 are presented in Figures 3-16 and $3-17$, respectively. In both boreholes, the means and standard deviations of volumetric water content values differ little among samples from the DB1, DRI1, and HGC core segments (Table 3-4). As expected, water content data were within the range of water content values found in nearby boreholes (REECo, 1994a). Volumetric water content profiles for the two boreholes, using only the DB1 and archive core segments, are shown in Figures 3-18. For both profiles, the only noticeable trend is a slight increase in water content with increasing depth. No significant differences were evident in water content between samples from boreholes D1 and U1. The mean volumetric water content for samples from Borehole D1 is slightly larger (approximately 1 percent) than that from Borehole U1 (Table 3-4). From the moisture retention curves (Figures 3-12 and 3-13), these mean water content values correspond to very low water potentials. This indicates that the alluvium, both beneath and adjacent to the disposal unit, is dry; therefore, water flux is small to nonexistent. Water potential data (Section 3.6.2) support this conclusion.

\subsubsection{Total Hydraulic Potential}

The two major components of total hydraulic potential are water potential and gravitational potential. Water potential is the energy required to pull a unit mass of water from the unsaturated soil, and gravitational potential is the energy required to move a unit mass of pure, free water from a reference elevation (Kirkham and Powers, 1972). The reference elevation for the gravitational potential was established as the ground surface; thus, gravitational potential at a given vertical depth will equal -1 times the depth. For example, gravitational potential of a soil sample taken from a vertical depth of $9 \mathrm{~m}$ (30 ft) will be $-9 \mathrm{~m}(-30 \mathrm{ft})$. In arid areas such as Yucca Flat, the near-surface alluvium is typically dry. Under dry conditions, the water potential gradient is the dominant driving force affecting soil water movement.

Water potential measurements were made on the DRI1 core segment from each run. Water potential and total hydraulic potential data for geologic samples are listed in tabular form in Appendix C. Descriptive statistics for water potential and total hydraulic potential are given in Table 3-5. Because there is a vertical trend in the total hydraulic potential, profiles of the total 


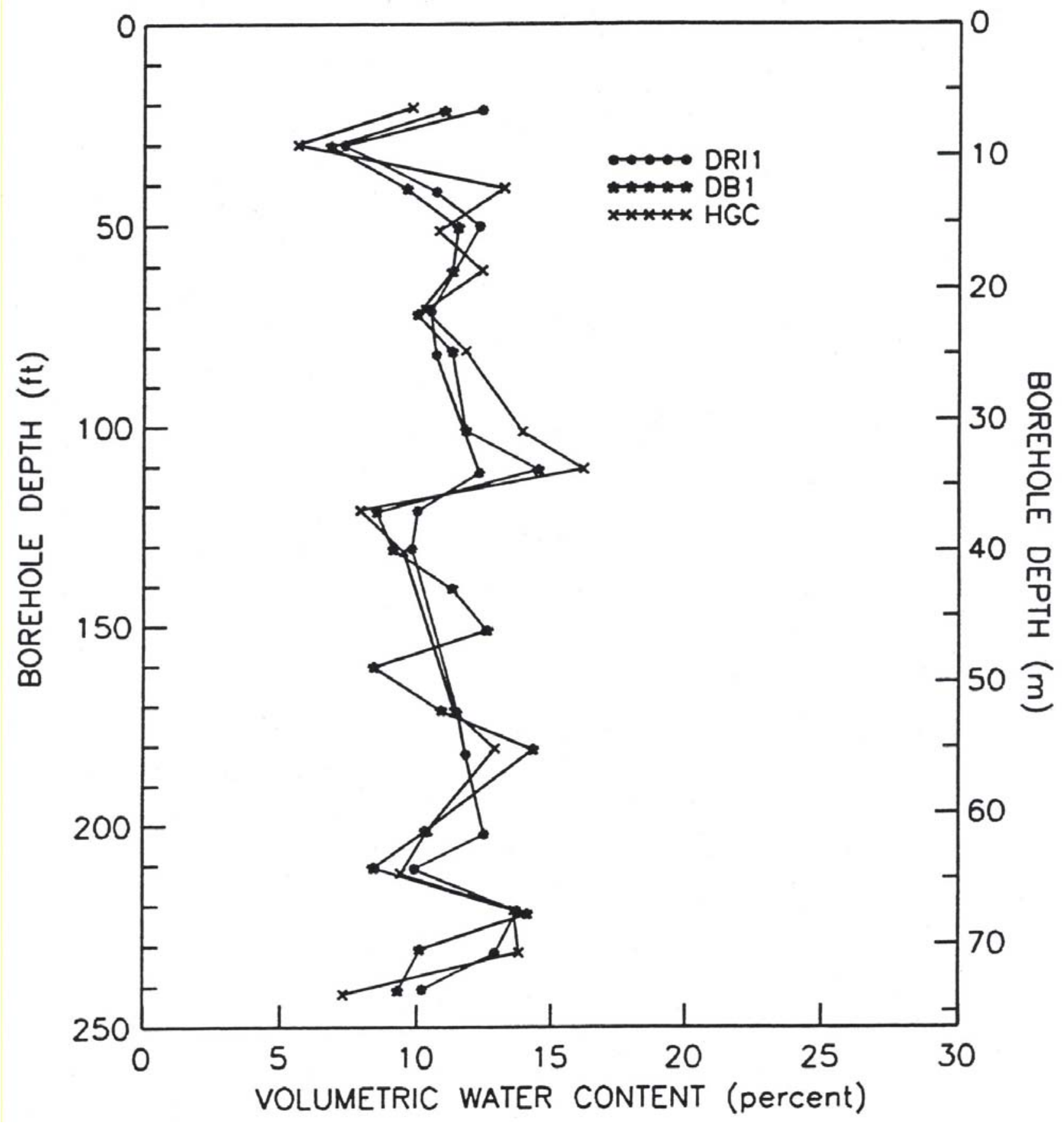

Figure 3-16

Slant Depth Profiles of Water Content for Core Samples from UE-3bl-D1 


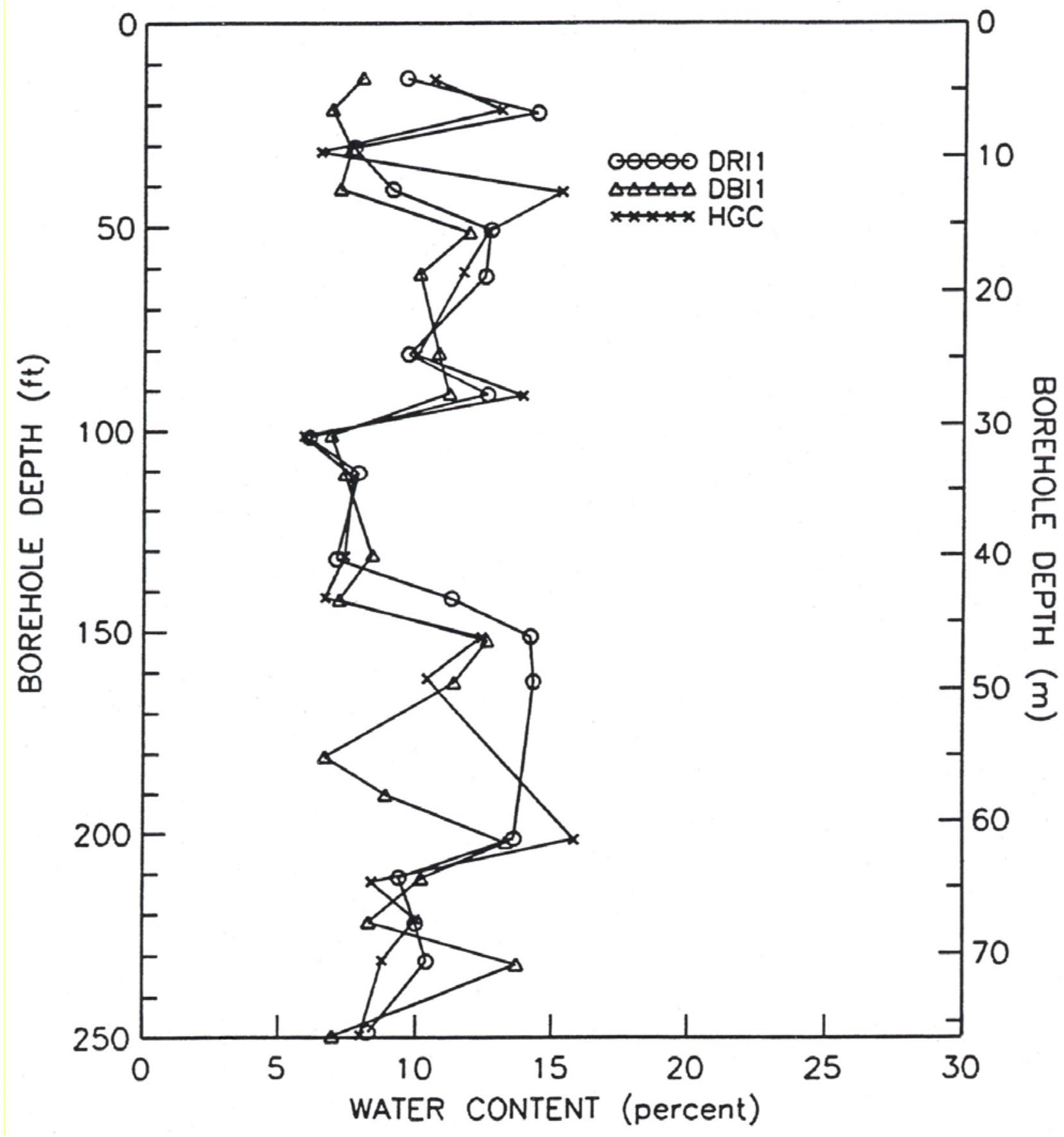

Figure 3-17

Slant Depth Profiles of Water Content for Core Samples from UE-3bl-U1 


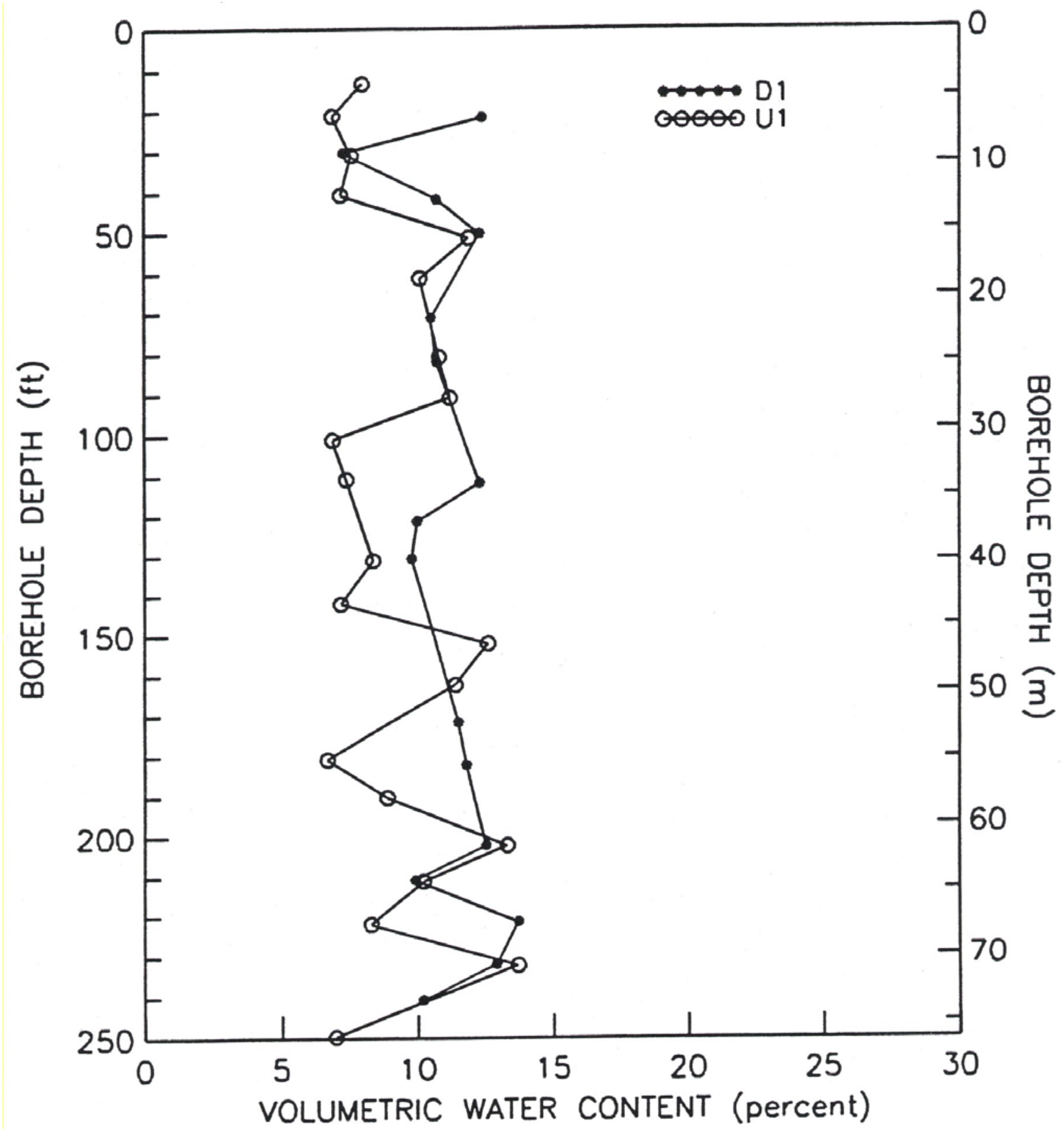

Figure 3-18

Slant Depth Profiles of Volumetric Water Content for DB1 Core Samples from the U3ax/bl Exploratory Boreholes 
hydraulic potential data represent vertical depth instead of slant depth (Figure 3-19). The profiles show an upward gradient for the entire depth (approximately $50 \mathrm{~m}$ [165 ft]) of both boreholes. Despite this upward gradient, upward flux is likely to be small because the unsaturated hydraulic conductivity (Figures 3-14 and 3-15) at in-situ water content is several orders of magnitude smaller than the saturated hydraulic conductivity.

\subsection{Pneumatic Properties}

REECo SPS personnel completed air permeability tests on five 15.3-cm (6-in.) core samples from Borehole D1. These tests were conducted to obtain the effective permeability $(k)$ in units

of square meters $\left(\mathrm{m}^{2}\right)$. This testing method measures the air pressure gradient required to move air through a core sample under steady-state conditions at a given flow rate. Pressure measurements under steady-state conditions were made at a minimum of nine different flow rates. Data from these measurements were used to calculate the effective permeability for a core sample using the extended Darcy’s equation (Scheidegger, 1974), which adapts Darcy's equation so that it applies to air flow through a porous medium. The procedure for air permeability testing is listed in Table 3-1.

Results of the air permeability tests are given in Appendix C. Descriptive statistics for the effective permeability are listed in Table 3-3. A plot of effective permeability values versus depth for Borehole D1 is shown in Figure 3-20, along with a plot of calculated permeability values versus depth for both boreholes, derived from the saturated hydraulic conductivity data (Section 3.5). The air permeability results obtained by the two methods are similar. This is as expected, although the interaction between the soil matrix and water can reduce the permeability of the medium. However, in the sandy alluvium of the samples from Borehole D1, this interaction was expected to be small.

\subsection{Environmental Tracers}

Environmental tracers provide a method, independent of the hydraulic parameters, of estimating water movement in the vadose zone. In this study, two types of environmental tracers were used: dissolved ions, such as chloride and bromide, that travel in solution with the soil water through the vadose zone; and isotopes, stable and radioactive, which are part of the water molecule itself. The concentrations of these tracers are measured with depth. Analysis of the profile data yields information concerning the history of water movement through the unsaturated zone. In the following sections, only qualitative observations concerning tracer profiles are made. 


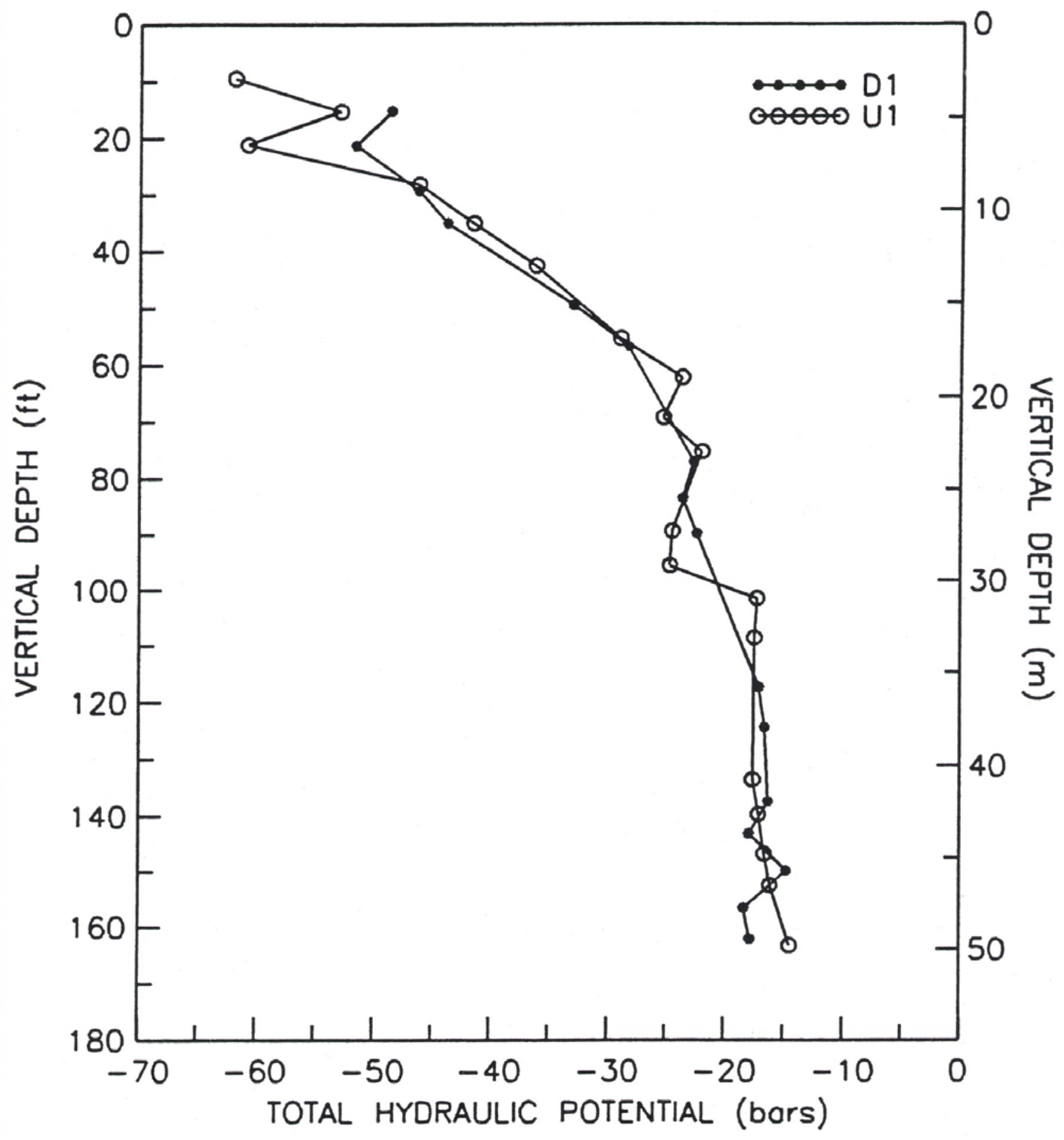

Figure 3-19

Vertical Depth Profiles of Total Hydraulic Potential for Core Samples from the U3ax/bl Exploratory Boreholes 


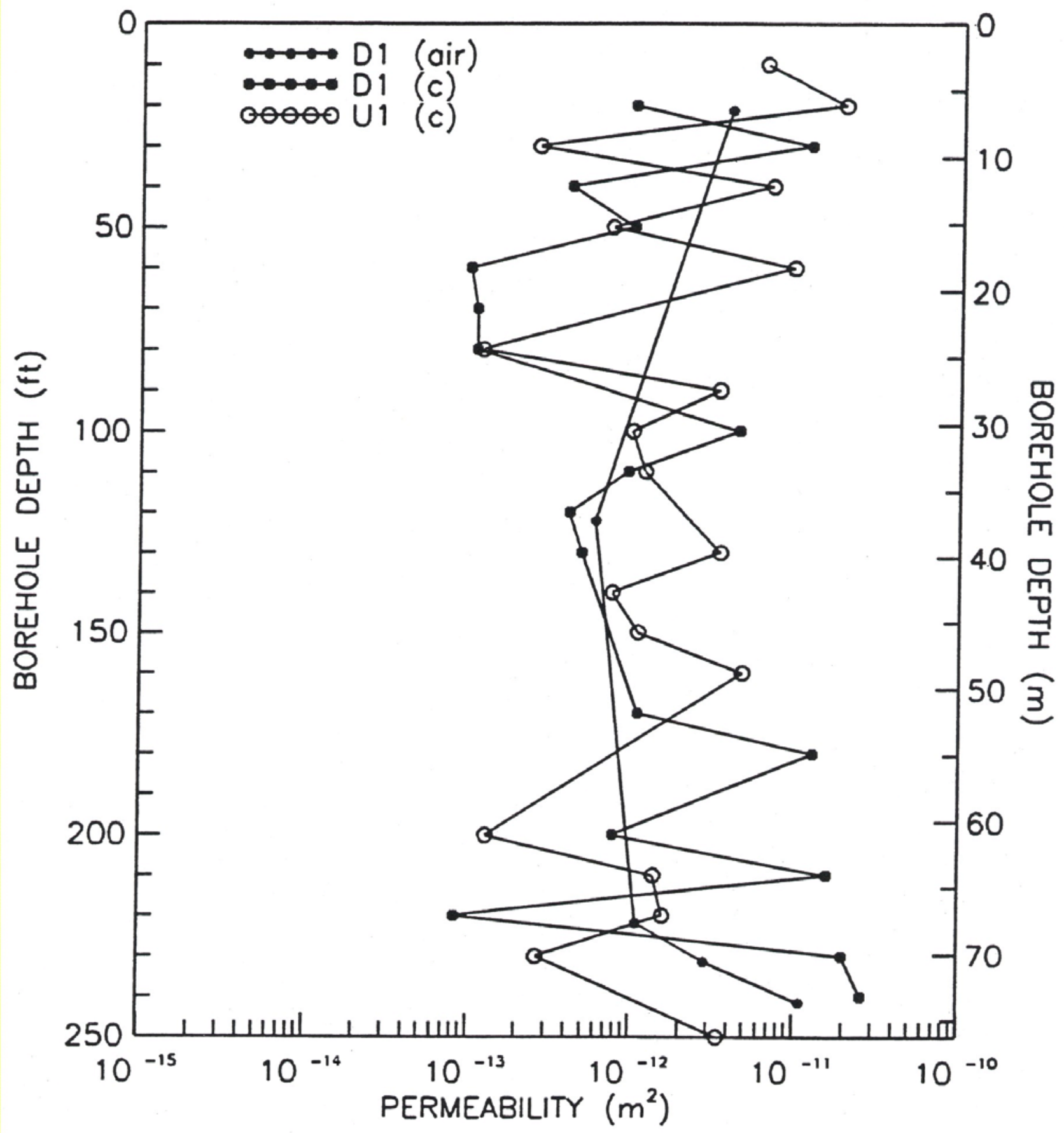

Figure 3-20

Slant Depth Profiles of Air Permeability for UE-3bl-D1 and Calculated (c) Permeability for Core Samples from the U3ax/3bl Exploratory Boreholes

(in square meters) 


\subsubsection{Chloride-Bromide Profiles}

Chloride and bromide ions can serve as tracers because their negative charge discourages sorption with negatively charged mineral surfaces in soils (Allison, 1988). Chloride and bromide ions primarily enter the soil as dissolved components of precipitation. These ions also enter the soil in lesser and more variable amounts, as salts contained in aeolian dust, which can dissolve in water infiltrating into the soil. As water evaporates, the concentration of these ions increases. Plots of the concentrations of these ions versus depth provide insight into the hydrogeologic condition of the vadose zone over time (Conrad, 1993). At depths where the ion concentrations are large, the hydrogeologic condition of the vadose zone at the time these ions were emplaced was such that the evaporation rate exceeded the infiltration rate. Conversely, at depths where ion concentrations are small, conditions were such that the infiltration rate exceeded the evaporation rate.

Chloride and bromide concentrations were measured on core samples. Descriptive statistics for the chloride-bromide ratios for the core samples are presented in Table 3-7. Tabular data are listed in Appendix C. Depth profiles of chloride and bromide concentrations, per unit dry weight of soil, for boreholes D1 and U1, are shown in Figures 3-21 and 3-22, respectively.

The depth profiles of the chloride and bromide concentrations for both boreholes indicate similar trends: namely, chloride and bromide concentrations in the upper part of each profile are greater than those in the remainder of the profile. The chloride and bromide depth profiles are similar to the profiles obtained from core samples at the NTS Area 5 RWMS within Frenchman Flat (REECo, 1995; BN, 2005a). Based on chloride data from Area 5, Conrad (1993) hypothesized that low chloride concentration at depth suggest that this water entered the subsurface under wetter climate conditions, when infiltration exceeded evaporation.

If water movement in the upper profile is upward, as described in Section 3.6.2, large chloride and bromide concentrations would be expected in the upper alluvium. This is what was observed.

Although trends in the chloride and bromide profiles for both boreholes were the same, the concentrations in the upper profile of Borehole U1 were at least two times greater than those of Borehole D1. The high ion concentrations in Borehole D1 occurred at a slant depth of approximately $9 \mathrm{~m}$ (30 ft), which is still in undisturbed alluvium (i.e., not yet beneath the crater). 


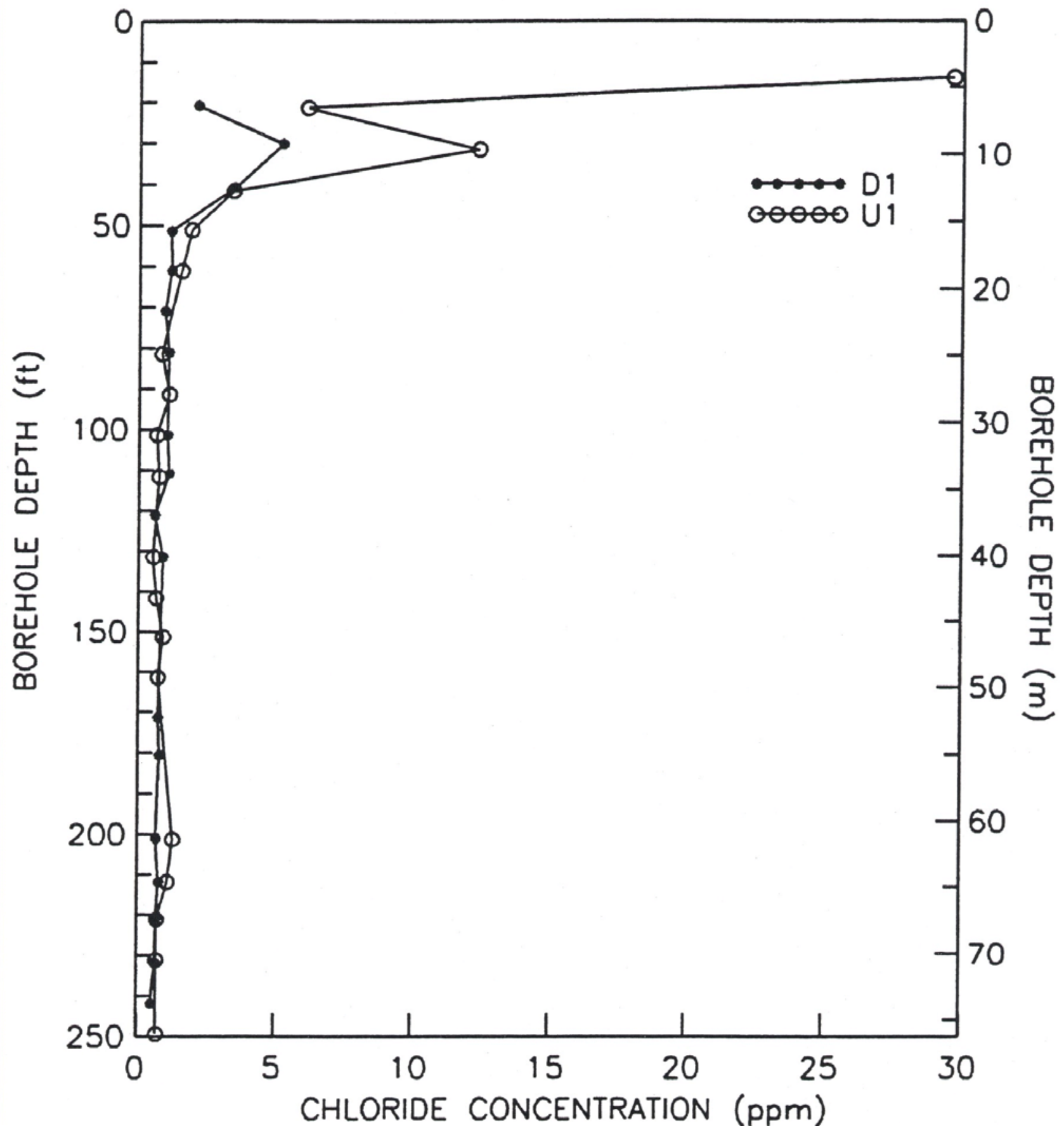

Figure 3-21

Slant Depth Profiles of Dry Soil Chloride Concentrations for Core Samples from the U3ax/bl Exploratory Boreholes (in parts per million) 


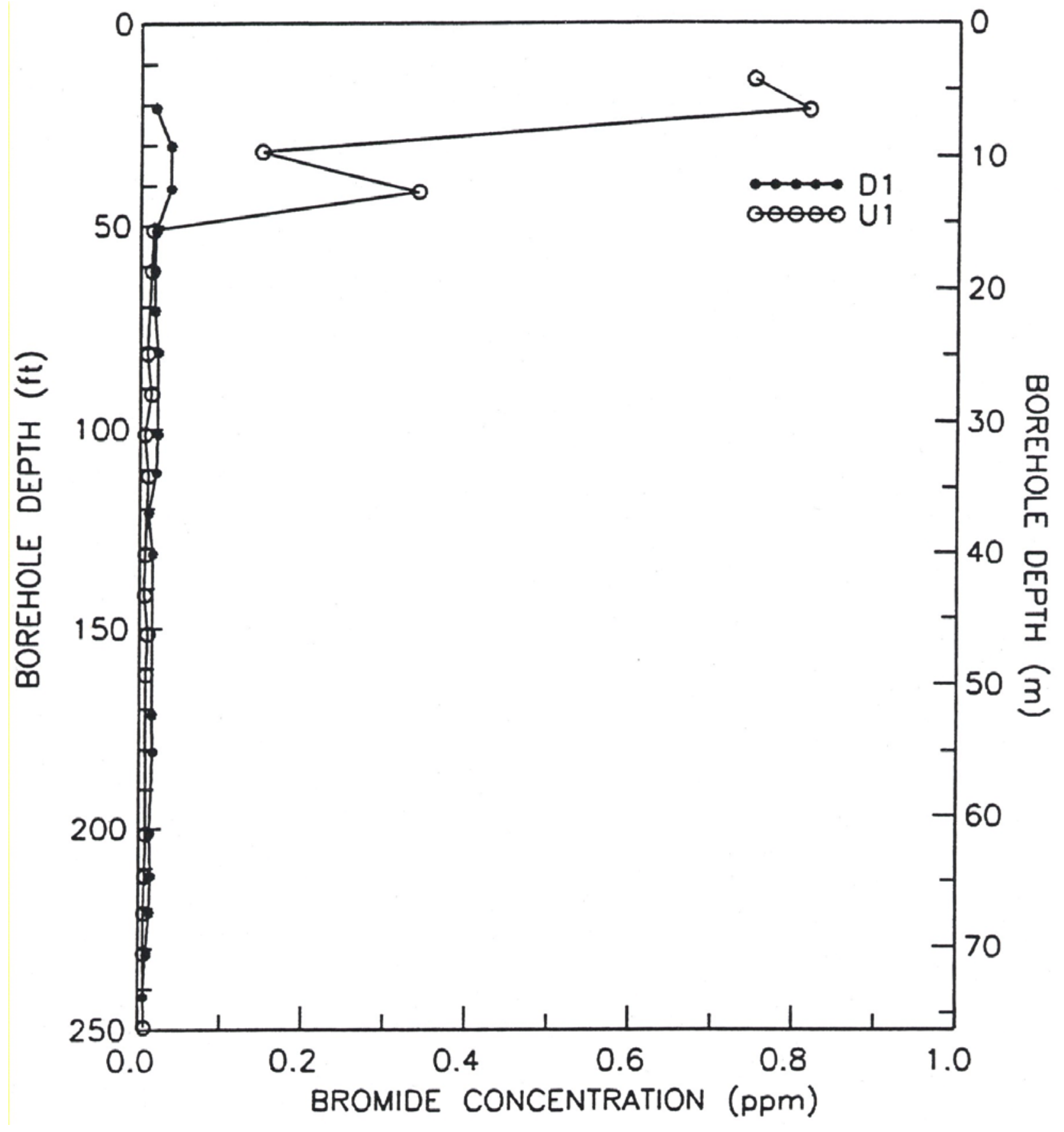

Figure 3-22

Slant Depth Profiles of Dry Soil Bromide Concentrations for Core Samples from the U3ax/bl Exploratory Boreholes (in parts per million) 
The reason for the difference in concentrations between the two boreholes is uncertain. Even though the boreholes are only $12 \mathrm{~m}$ (40 ft) apart, the location of Borehole U1 may have received historically more runoff than the location of Borehole D1. The current topography does not suggest that the Borehole U1 location receives more water than the Borehole D1 location. However, both boreholes are located in an area that has been graded periodically over the last 30 years, potentially concealing washes and shallow drainage swales that might have existed under natural conditions. Also, during waste disposal operations for U3ax/bl, water trucks were used for dust control. The location of Borehole U1 may have received more water from these trucks or another artificial source than the location of Borehole D1.

Chloride-bromide ratios (Figure 3-23) are useful in evaluating precision in laboratory measurements. A constant ratio indicates good laboratory precision. The ratios for the samples from Borehole D1 are relatively constant, whereas the ratios for the samples from Borehole U1 vary widely throughout the profile. The variability in the ratios for samples from BoreholeU1 raises questions about the validity of the measurements made on these samples. Because there is more variability in the bromide profiles than in the chloride profiles, the Borehole U1 bromide concentrations are more suspect.

For both boreholes $\mathrm{U} 1$ and $\mathrm{D} 1$, the chloride-bromide ratio is more variable at shallow depths than at greater depths, as can be seen in Figure 3-23. This is probably due to evaporation causing the variability in concentrations in both chloride and bromide to be greater at shallow depths than at greater depths (see Figures 3-21 and 3-22).

\subsubsection{Stable Isotope Profiles}

The stable isotopes of hydrogen (deuterium, $\mathrm{D}$, and hydrogen, $\mathrm{H})$ and oxygen $\left({ }^{18} \mathrm{O}\right.$ and $\left.{ }^{16} \mathrm{O}\right)$ are excellent tracers of water movement because these isotopes are components of the water molecule itself (Allison, 1988). Stable isotopes are used in unsaturated zone studies to infer the source of soil water and to determine if evaporation has occurred. Results are reported as ratios

of heavy to light isotopes $\left(\mathrm{D} / \mathrm{H}\right.$ and $\left.{ }^{18} \mathrm{O} /{ }^{16} \mathrm{O}\right)$ in delta notation $(\delta)$ relative to standard mean ocean water (Craig, 1961).

Fractionation, or change in this ratio, occurs during phase change processes. Therefore, condensation and evaporation processes affect isotopic ratios. The condensation of precipitation occurs under near thermodynamic equilibrium conditions, resulting in a linear relationship between hydrogen and oxygen isotopes in worldwide precipitation known as the meteoric water 


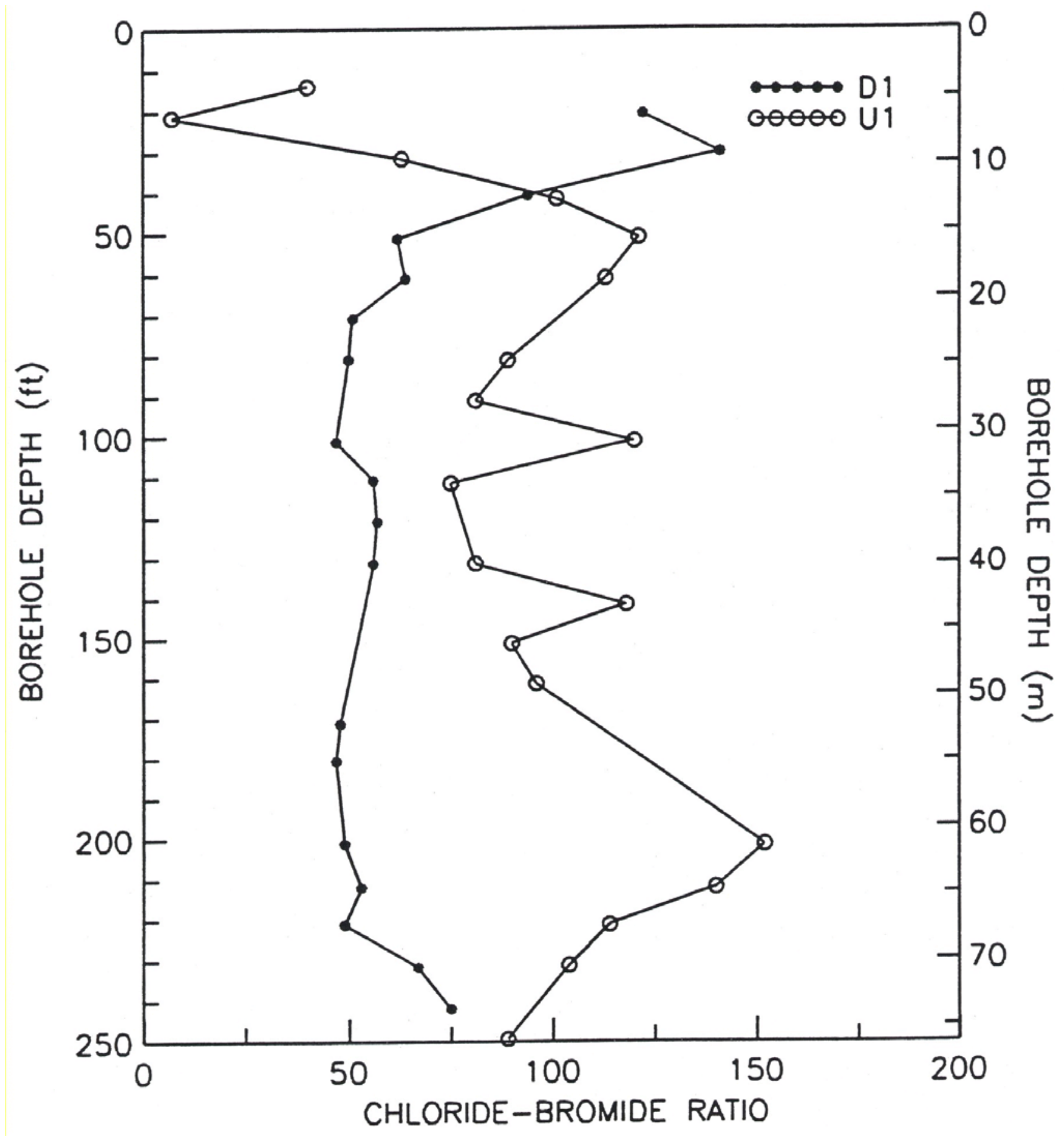

Figure 3-23

Slant Depth Profiles of Dry Soil Chloride-Bromide Ratios for Core Samples from the U3ax/bl Exploratory Boreholes 
line (MWL) (Craig, 1961). Evaporation of water generally occurs under non-equilibrium conditions. Under these conditions, fractionation of oxygen isotopes is greater than that of hydrogen isotopes. Thus, the water remaining behind in the evaporation process develops an isotopic composition that plots to the right of the MWL.

Stable isotope data from the boreholes is listed in Appendix C, descriptive statistics for core samples are given in Table 3-5, and depth profiles for the boreholes are presented in Figure 3-24. In general, the profiles from both boreholes show enrichment of heavy isotopes, indicating that evaporation is occurring.

A plot of oxygen isotope ratios from selected core sample from each borehole, with the MWL for reference, is shown in Figures 3-25 and 3-26. The data from both boreholes plot to the right of the MWL, on a line with a smaller slope. This slope is within the range of values found by Allison (1982) in experiments in which water was evaporated from sand columns; it strongly suggests that evaporation rates are high, relative to the downward rate of water movement in the upper vadose zone under the present climate (REECo, 1995; BN, 2005a). This provides further evidence of the conclusion drawn from the water potential data, that water movement in the near-surface alluvium is upward. Also, no recognizable difference in the isotope ratios was apparent between the two boreholes.

\subsubsection{Tritium Profiles}

Tritium, with a half-life of 12.3 years, is also effective tracer because it is part of the water molecule itself. Before extensive atmospheric nuclear weapons testing began in 1952, environmental tritium concentrations in meteoric waters were low and in many cases, nondetectable (Drever, 1988). However, tritium concentrations in precipitation and soil water began increasing in 1952 because of atmospheric testing. Consequently, if tritium concentrations in soil water exceed enrichment detection levels (approximately $16 \mathrm{pCi} / \mathrm{L}$ ), the water must either have infiltrated into the soil after 1952 or the concentrations were enhanced from a source other than atmospheric testing, such as underground nuclear testing or the waste disposed in U3ax/bl (REECo, 1994b).

Tritium concentrations in precipitation reached a peak in the early 1960s, at concentrations of about 10,000 pCi/L (National Council on Radiation and Protection Measurements, 1975). Assuming tht precipitation with a tritium concentration of $10,000 \mathrm{pCi} / \mathrm{L}$ infiltrated into the soil at the Area 3 RWMS in 1964, the tritium concentration after 30 years would be less than 


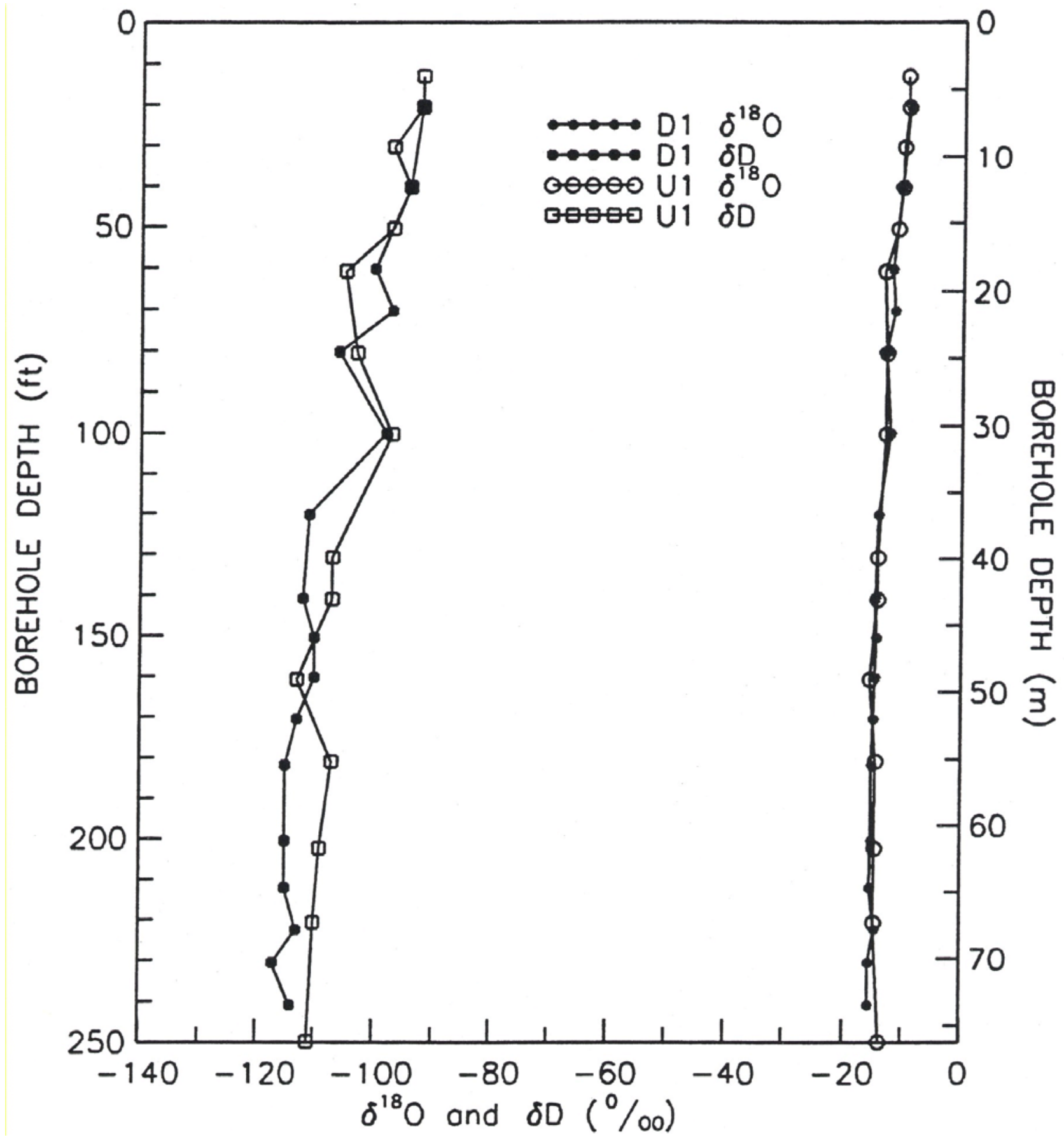

Figure 3-24

Slant Depth Profiles of Stable Isotopes for Core Samples from the U3ax/bl Exploratory Boreholes

(Oxygen-18 and Deuterium [per mil] in standard delta [ठ] notation) 


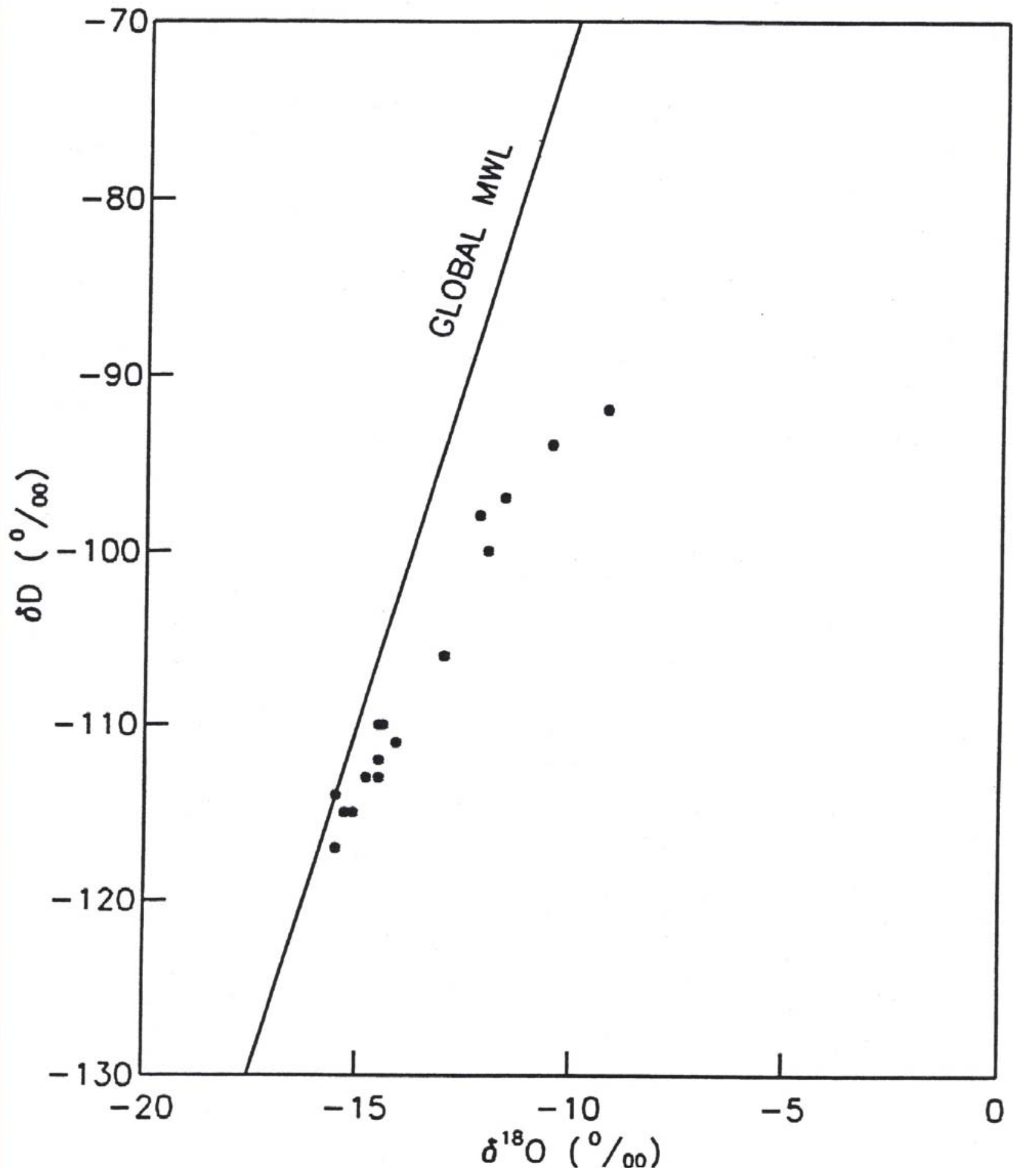

Figure 3-25

Comparison of Measured Stable Isotopes for Core Samples from UE-3bl-D1 with Stable Isotope Data for the Global Meteoric Water Line (MWL) (Oxygen-18 and Deuterium [per mil] in standard delta [ठ] notation) 


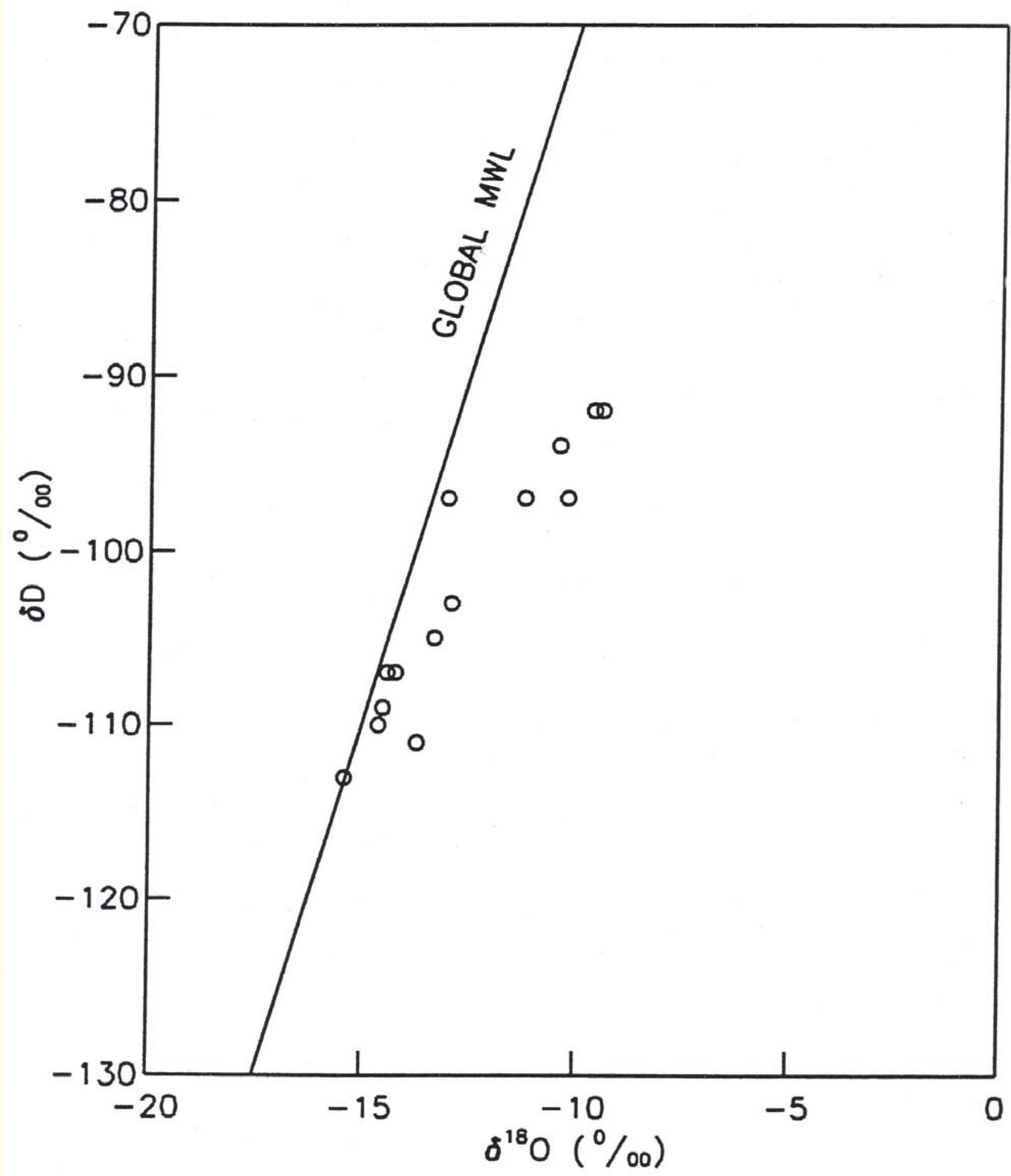

Figure 3-26

Comparison of Measured Stable Isotopes for Core Samples from UE-3bl-U1 with Stable Isotope Data for the Global Meteoric Water Line (MWL) (Oxygen-18 and Deuterium [per mil] in standard delta [ठ] notation) 
2,500 $\mathrm{pCi} / \mathrm{L}$ in soil water. If tritium concentrations in the soil water from the samples exceed $2,500 \mathrm{pCi} / \mathrm{L}$, then the tritium is likely from sources other than atmospheric testing.

Eight drill cuttings samples and ten core sample were collected from Borehole D1 for unenriched tritium analyses. The drill cuttings samples were taken at slant depths of approximately 4, 18, 46, and $73 \mathrm{~m}(13,60,150$, and $240 \mathrm{ft})$. The cuttings were placed in 3.8-L (1-gal) containers, one for each depth. Two samples were taken from each container, one sample from near the middle, and the other from near the top of the container. The ten core samples were added later to provide tritium concentration data at more intervals throughout the borehole. In addition, ten core samples were collected from Borehole U1 for unenriched tritium analyses. Descriptive statistics for the tritium concentrations are listed in Table 3-5. A plot of tritium versus depth is shown in Figure 3-27. Appendix C contains the data in tabular form.

The samples were analyzed by DRI using a vacuum distillation method to extract the water from the soil and a 2500TR Packard ${ }^{\circledR}$ Liquid Scintillation Counter to measure the tritium. The tritium concentrations in samples from Borehole $\mathrm{U} 1$ are all less than $850 \mathrm{pCi} / \mathrm{L}$, decreasing with depth to levels near or below the detection limit of $350 \mathrm{pCi} / \mathrm{L}$. The concentrations below the detection limit are plotted on Figure 3-27 at $350 \mathrm{pCi} / \mathrm{L}$. On the other hand, tritium concentrations in samples from Borehole D1 were higher than those from Borehole U1, ranging from 471 to 9,240 pCi/L. In Borehole D1, the tritium concentrations generally increase with depth. These concentrations from Borehole D1 suggest sources other than past atmospheric testing, such as the waste from the U3ax/bl disposal unit or the materials associated with the underlying nuclear test BOBAC. Therefore tritium would not be appropriate as an environmental tracer beneath $\mathrm{U} 3 \mathrm{ax} / \mathrm{bl}$.

These concentrations may be too large for tritium to serve as an environmental tracer, but they are still less than 1 percent of the Nuclear Regulatory Commission's concentration limit of $1,000,000 \mathrm{pCi} / \mathrm{L}$ for effluent released to an unrestricted area (Title $10 \mathrm{CFR} \S 20$ ). Also, the observed tritium concentrations were smaller than many concentrations observed in precipitation in the early 1960s (National Council on Radiation and Protection Measurements, 1975). 


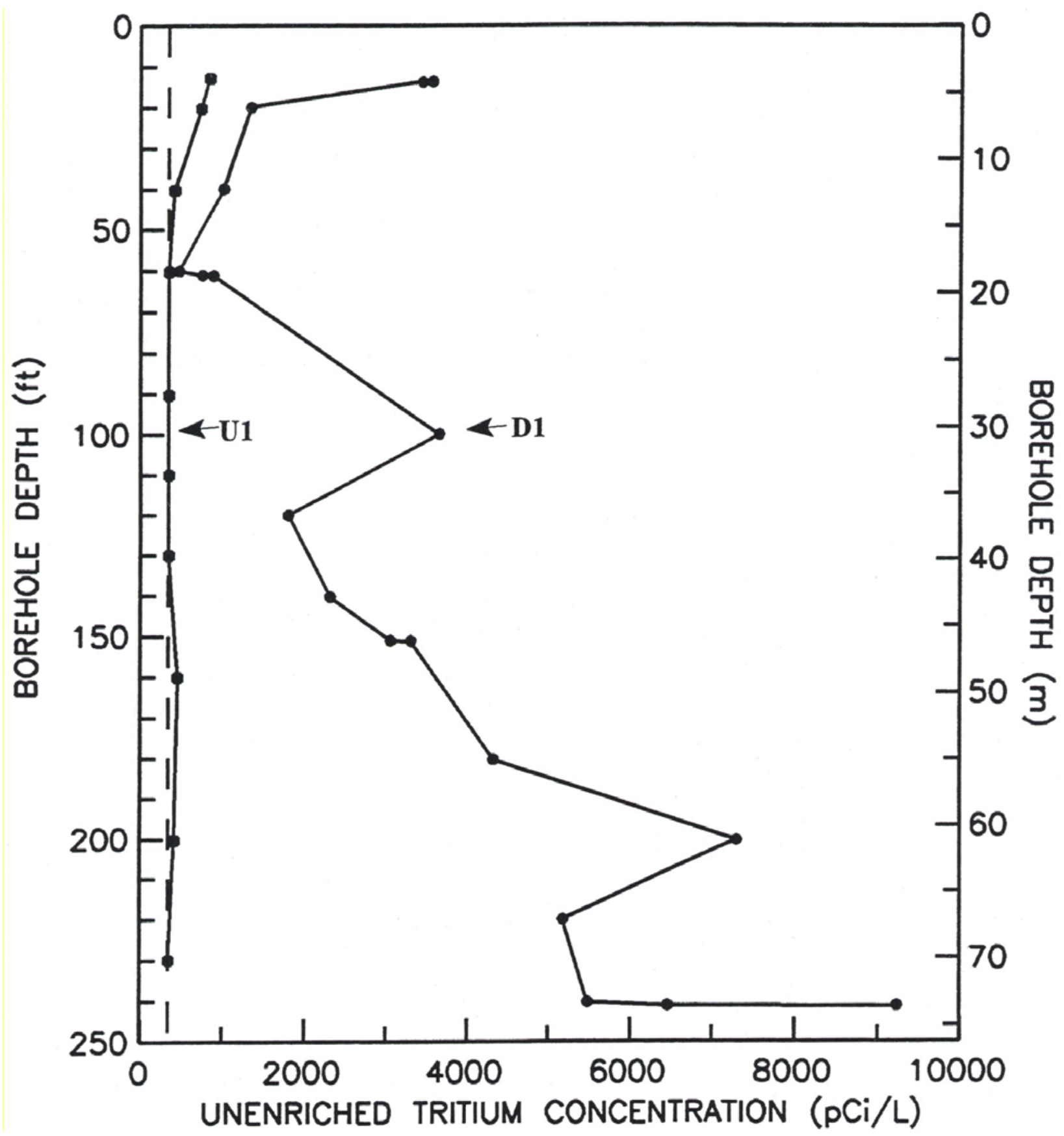

Figure 3-27

Slant Depth Profiles of Unenriched Tritium Concentrations for Geologic Samples from the U3ax/bl Exploratory Boreholes

(Vertical dashed line indicates the detection limit of 350 picoCuries per liter.) 
This page intentionally left blank. 


\subsection{Directional Survey Results}

The subcontractor, Christiansen Boyles Corporation-WELNAV, conducted directional surveys in boreholes U1 and D1 using a gyroscopic directional survey tool. Data were collected at points

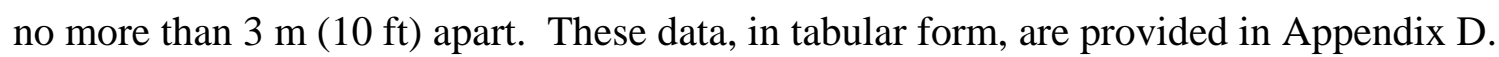

Figure 1-2 shows that Borehole D1 was drilled beneath the U3ax/bl disposal unit. Because the casing detached at the slant depth of approximately $74 \mathrm{~m}$ (242 ft), drilling of Borehole D1 stopped short of the target slant depth of $91 \mathrm{~m}$ (300 ft). Thus, it is not certain that Borehole D1 entered the U3bl chimney. The intended slant depth of $91 \mathrm{~m}$ (300 ft) would have placed the borehole directly above the U3bl cavity and clearly within the chimney.

Using the directional survey data, a profile view of Borehole D1 was plotted relative to the U3bl crater, the cavity, and the potential chimney boundaries (Figure 4-1). The horizontal coordinates and dimensions of the U3bl crater were obtained from a topographic map (Holmes \& Narver, 1962). The location of the cavity center and its estimated radius were obtained from the Los Alamos National Laboratory database (Hawkins, 1993).

Two major models of chimney shape, cylindrical and inverted cone, have been proposed (Houser, 1970). Of the two models, the cylindrical model is the most widely accepted (Houser, 1970). In this model, the chimney extends vertically from the cavity; Houser (1970) notes that the radius of the chimney is about 10 percent larger than the cavity. In the inverted cone model, the radius of the chimney starts roughly the same as the cavity, expanding outward as the chimney grows upward. Chimney boundaries shown in Figure 4-1 reflect these models. The diagonal boundaries extending from the edge of the cavity to the outer edge of the crater represent the inverted cone model, and the vertical boundaries, maintaining roughly the same radius as the cavity, represent the cylindrical model. Figure 4-1 shows that the borehole is clearly within the chimney if the inverted cone model holds, but approximately $3 \mathrm{~m}$ (10 ft) outside the chimney if the cylindrical model applies and the chimney has, contrary to expectations, the same radius as the cavity. Because chimney boundaries in unconsolidated material are likely not distinctive, it would be possible to say with certainty that Borehole D1 penetrated the chimney only if the borehole was clearly above the cavity of BOBAC, which is not the case. 


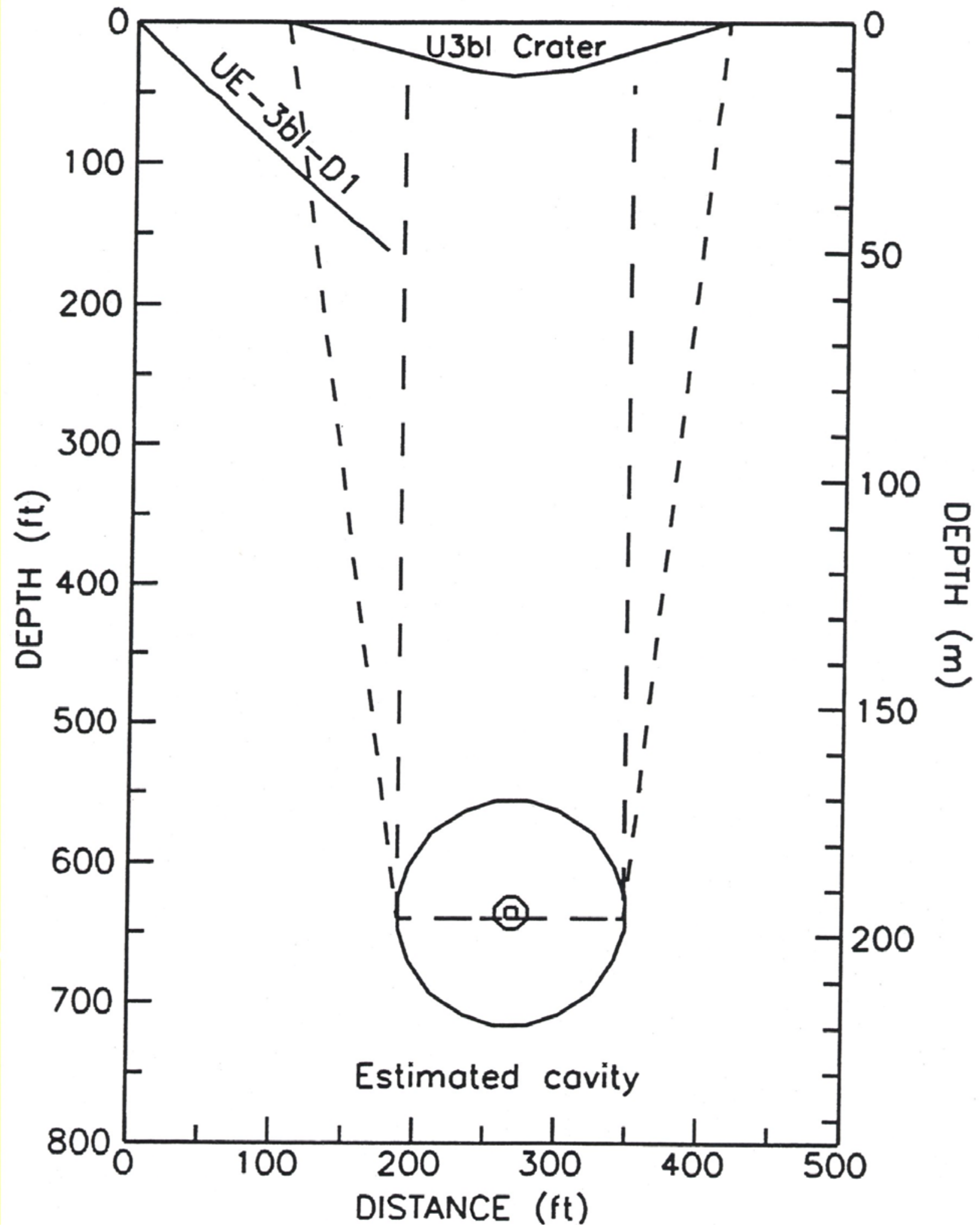

Figure 4-1

Cross Section Showing UE-3bl-D1 Relative to the Estimated Positions of the U3bl Crater/Chimney/Cavity 


\subsection{Recommendations and Future Work}

The following are recommendations (from the 1996 version of this report) for future work to obtain a better understanding of the hydrogeologic system beneath the Area 3 RWMS, including the hydrogeologic conditions within chimneys:

- Future boreholes should be drilled deep enough to reach a zone where the soil water flux is no longer upward. Presently, that depth is unknown. Accordingly, it is recommended that the minimum depth of boreholes drilled in undisturbed alluvium be $122 \mathrm{~m}(400 \mathrm{ft})$, and boreholes that are proposed within the chimney should be drilled as deep as possible, without contacting radioactive contamination left by underground nuclear testing.

- A minimum of one borehole should be drilled into a chimney either within or near the Area 3 RWMS, with core samples taken every $3 \mathrm{~m}(10 \mathrm{ft})$. This borehole should start from the bottom of the crater to ensure that the samples collected are from within the chimney. Depth of penetration should be limited by safety considerations.

Several additional boreholes, including another hole beneath the U3ax/bl crater, have since been drilled at the Area 3 RWMS as a continuation of the effort to characterize the collapse zones beneath the U3ax/bl and U3ah/at waste disposal cells. See, for example, BN (2005b). 
This page intentionally left blank. 


\subsection{References}

Allison, G. B., 1982. The Relationship Between ${ }^{18} \mathrm{O}$ and Deuterium in Water and Sand Columns Undergoing Evaporation. Journal of Hydrology, v. 55, pp. 163-169

Allison, G. B., 1988. “A Review of Some of the Physical, Chemical, and Isotopic Techniques Available for Estimating Groundwater Recharge.” In: Simmers, I., ed., Estimation of Natural Groundwater Recharge. Reidel Publishing, pp. 49-72.

Bechtel Nevada, 2000. Closure Plan for Corrective Action Unit 110: Area 3 RWMS U-3ax/bl Disposal Unit, Nevada Test Site, Nevada. DOE/NV--647. Las Vegas, NV.

Bechtel Nevada, 2005a. Site Characterization and Monitoring Data from the Area 5 Pilot Wells. DOE/NV/11718--1067. Las Vegas, NV.

Bechtel Nevada, 2005b. Hydrogeologic Characterization of U-3at Collapse Zone. DOE/NV/11718--199-REV.1. Las Vegas, NV.

BN, see Bechtel Nevada.

Borg, I. Y., R. Stone, H. B. Levy, and L. D. Ramspott, 1976. Information Pertinent to the Migration of Radionuclides in Ground Water, Part I: "Review and Analysis of Existing Information.” Lawrence Livermore National Laboratory Report UCRL-52078.

Christensen, R. C., and N. E. Spahr, 1980. Flood Potential of Topopah Wash and Tributaries, Eastern Part of Jackass Flats, Nevada Test Site, Southern Nevada. U.S. Geological Survey Open File Report 80-963.

Craig, H., 1961. Standard for Reporting Concentrations of Deuterium and Oxygen-18 in Natural Waters. Science, v. 133, pp. 1,833-1,934.

Conrad, S. H., 1993. Using Environmental Tracers to Estimate Recharge Through an Arid Basin. 1993 International High-Level Radioactive Waste Management Conference, Las Vegas, NV. April 26-30, 1993.

DOE, see U.S. Department of Energy.

Doty, G. C., and W. Thordarson, 1983. Water Table in Rocks of Cenozoic and Paleozoic Age, 1980, Yucca Flat, Nevada Test Site, Nevada. U.S. Geological Survey Water Resources Investigations Report 83-4067 (map).

Drellack, S. L., Jr., 1994. Isopach Map of Alluvium in LANL-Use Areas, Yucca Flat, NTS. Raytheon Services Nevada, LANL Geologic Support Group. Map ID: QTAISO, Rev. 4. Mercury, NV. 
Drever, J. I., 1988. The Geochemistry of Natural Waters, Second Edition. Prentice Hall, Inc., Englewood Cliffs, NJ.

Fernald, A. T., 1974. Geology and Material Properties of the Area 3 "Sand Pile," Southeastern Yucca Flat, Nevada Test Site, Part I: “Geology.” U.S. Geological Survey Special Projects Branch.

Freeze, R. A., and J. A. Cherry, 1979. Groundwater. Prentice-Hall, Inc., Englewood Cliffs, NJ.

Hammermeister, D. P., D. O. Blout, and J. C. McDaniel, 1986. "Drilling and Coring Methods that Minimize the Disturbance of Cuttings, Core, and Rock Formations in the Unsaturated Zone, Yucca Mountain, Nevada.” In: Proceedings of the NWWA Conference on Characterization and Monitoring of the Vadose (Unsaturated) Zone, Denver, CO, 1985, pp. 506-541. National Water Well Association, Worthington, OH.

Hawkins, W., Los Alamos National Laboratory, 1993. Personal communication. Subject: "Estimated Depth and Cavity Radius for U-3bl.” Los Alamos, NM.

Holmes \& Narver, Inc., 1962. "Station U3bl: Portion of Area 3 Post Test Topography.” Scale: 1:480, Contour Interval: 2 feet. Map currently held in the Bechtel Nevada Archive and Records Center, Mercury, NV.

Houser, F. N., 1970. A Summary of Information and Ideas Regarding Sinks and Collapse, Nevada Test Site. U.S. Geological Survey Report USGS-474-41 (NTS-216).

Kirkham, D., and W. L. Powers, 1972. Advanced Soil Physics. Robert E. Krieger Publishing, Malabar, FL.

Mualem, Y., 1976. A New Model for Predicting the Hydraulic Conductivity of Unsaturated Porous Media. Water Resources Research, v. 12, pp. 513-522.

National Council on Radiation and Protection Measurements, 1975. Natural Background Radiation in the United States. National Council on Radiation and Protection Measurements, Washington, DC.

REECo, see Reynolds Electrical and Engineering Co.

Reynolds Electrical and Engineering Co., Inc., 1993. Hydrogeologic Data for Science Trench Boreholes at the Area 5 Radioactive Waste Management Site, Nevada Test Site, Nye County, Nevada. Special Projects Section, Environmental Management Division. Las Vegas, NV.

Reynolds Electrical and Engineering Co., Inc., 1994a. Written communication. Subject: "Archival Literature Search and Conceptual Model for the U3ax/bl Disposal Unit.” Las Vegas, NV.

Reynolds Electrical and Engineering Co., Inc., 1994b. Written communication. Subject: "U3ax/bl Waste Inventory Report. Las Vegas, NV. 
Reynolds Electrical and Engineering Co., Inc. 1995. Hydrogeologic Data for Science Trench Boreholes at the Area 5 RWMS, Nevada Test Site, Nye County, Nevada. Reynolds Electrical and Engineering Co., Inc. Special Projects Section, Environmental Management Division. Las Vegas, NV. DOE/NV/11432--40.

Scheidegger, A. E., 1974. The Physics of Flow Through Porous Media, Third Edition. University of Toronto Press, Toronto.

Tyler, S. W., W. A. McKay, and T. M. Miheve, 1992. Assessment of Soil Moisture Movement in Nuclear Subsidence Craters. Journal of Hydrology, v. 139, pp. 159-181.

U.S. Department of Energy, Nevada Operations Office, 2000. United States Nuclear Tests, July 1945 through September 1992. DOE/NV-209, Revision 15. Las Vegas, NV.

van Genuchten, M. Th., 1978. Calculating the Unsaturated Hydraulic Conductivity with a New Closed-Form Analytical Model. Water Resources Program, Dept. of Civil Engineering, Princeton Univ., Princeton, NJ Res. Rpt. 78-WR-8, 63p.

van Genuchten, M. Th., 1980. A Closed-Form Equation for Predicting the Hydraulic Conductivity of Unsaturated Soils. Soil Science Society of America Journal, v. 45, pp. 892-898. 
This page intentionally left blank. 


\section{U3ax/bl Exploratory Boreholes}

Appendix A

Drilling Information 


\title{
U3ax/bl Exploratory Boreholes
}

\author{
Appendix A \\ Drilling Information
}

A-1 Chronological Drilling Summary for Borehole UE-3bl-D1 
Table A-1

Chronological Drilling Summary for Borehole UE-3bI-D1

\begin{tabular}{|c|c|c|c|}
\hline $\begin{array}{l}\text { Date } \\
(1994)\end{array}$ & $\begin{array}{c}\text { Casing } \\
\text { Borehole } \\
\text { Depth (feet) }\end{array}$ & $\begin{array}{c}\text { Core } \\
\text { Run } \\
\text { Number }\end{array}$ & Activity \\
\hline $06 / 09$ & & & $\begin{array}{l}\text { Excavate 10-ft-deep cellars for boreholes D1 and U1. Place casing. Unload } \\
\text { gravel. }\end{array}$ \\
\hline $06 / 13$ & & & Spread and prepare gravel pad for boreholes D1 and U1. Relocate corners. \\
\hline $06 / 14$ & & & Move equipment, logging, trailer, and transportainer onsite. \\
\hline $06 / 15$ & & & Steam-clean equipment. \\
\hline $06 / 20$ & & & Move drill rig on to the Borehole D1 site. \\
\hline $06 / 21$ & & & $\begin{array}{l}\text { Move drill support equipment onsite. Install oil separator, stand, and accelerator } \\
\text { cable on rig. }\end{array}$ \\
\hline $06 / 22$ & & & Unload casing. DOE inspection. \\
\hline $06 / 23$ & & & $\begin{array}{l}\text { Gamma alarm installed. Inspection by Occupational Safety. Dust collection } \\
\text { system onsite. Fabricate connections. }\end{array}$ \\
\hline $06 / 24$ & & & Place 65/8-in. casing in hole. Connect fittings and hoses to dust control system. \\
\hline $06 / 27$ & 12.5 & 1 & Fabricate pack-off and guide. \\
\hline $06 / 28$ & 22.5 & 2 & Fabricate pack-off. Add mini-cyclone to cyclone. \\
\hline $06 / 29$ & 50.0 & 3,4 & \\
\hline $06 / 30$ & 60.0 & 5 & Industrial Health inspects site. Rig down for repairs. \\
\hline $07 / 05$ & & & Down for repairs. \\
\hline $07 / 11$ & 70.0 & 6,7 & \\
\hline $07 / 12$ & 100.0 & 8,9 & \\
\hline $07 / 13$ & 110.0 & 10,11 & Core barrel broke of in hole; retrieved with over-shot. \\
\hline $07 / 14$ & & & $\begin{array}{l}\text { Fix rig pipe handler hydraulics. Environmental Compliance Office (ECO) } \\
\text { inspection. }\end{array}$ \\
\hline $07 / 15$ & 130.0 & 12 & DOE and Nevada Division of Environmental Protection (NDEP) inspection. \\
\hline $07 / 18$ & 132.5 & 13 & \\
\hline $07 / 19$ & 150.0 & 14 & Wet core samples. \\
\hline $07 / 20$ & & & $\begin{array}{l}\text { Environmental Protection Agency, DOE, NDEP, and ECO onsite. Rig hydraulic } \\
\text { problems. WELNAV directional survey. }\end{array}$ \\
\hline $07 / 21$ & 152.2 & 15 & Broke rig hydraulic line. \\
\hline $07 / 25$ & 170.0 & 16,17 & \\
\hline $07 / 26$ & 190.0 & 18,19 & \\
\hline $07 / 27$ & 200.0 & 20 & \\
\hline $07 / 28$ & 220.0 & 21 & \\
\hline $07 / 29$ & 230.0 & 22,23 & \\
\hline $08 / 01$ & 240.0 & 24 & \\
\hline $08 / 02$ & 241.5 & & Casing separated. \\
\hline
\end{tabular}


This page intentionally left blank. 


\title{
U3ax/bl Exploratory Boreholes
}

\author{
Appendix B
}

Core and Drill Cuttings Sample Description Data 


\title{
U3ax/bl Exploratory Boreholes
}

\author{
Appendix B \\ Core and Drill Cuttings Sample Description Data
}

B.1 Borehole Log Sheets for UE-3bl-D1

B.2 Borehole Log Sheets for UE-3bl-U1

B.3 Drill Cuttings Log Data for UE-3bl-D1

B.4 Drill Cuttings Log Data for UE-3bl-U1 


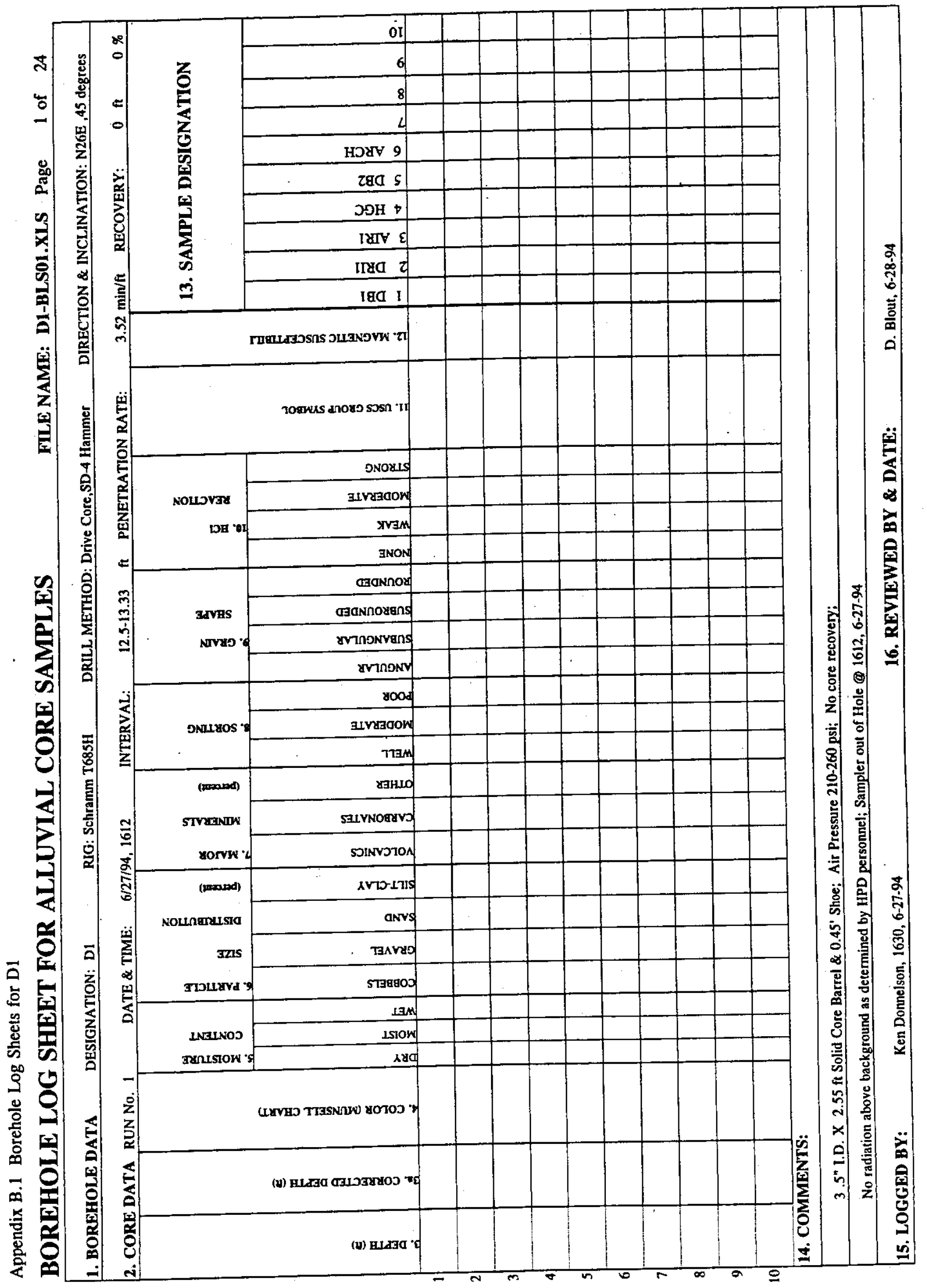




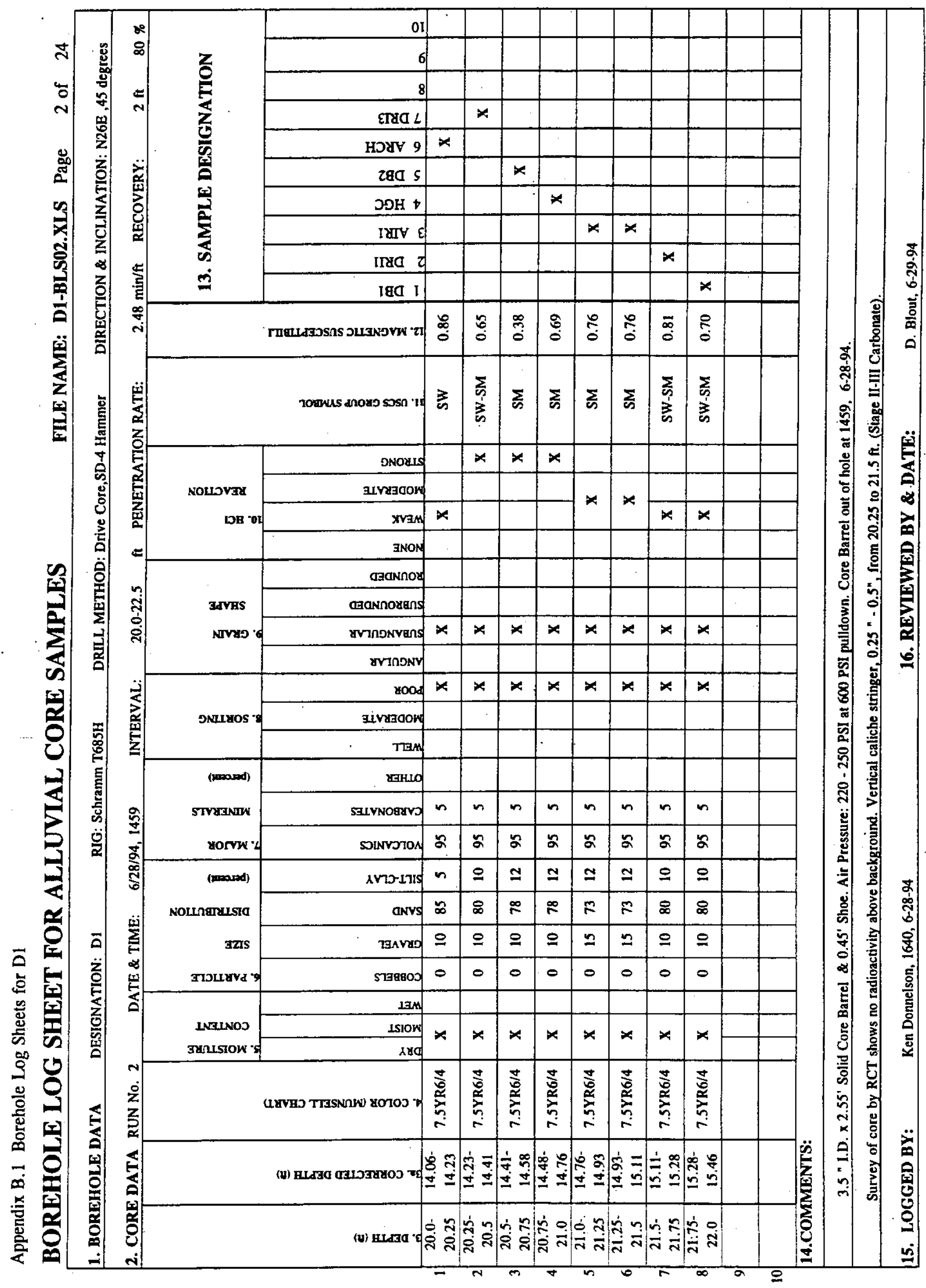




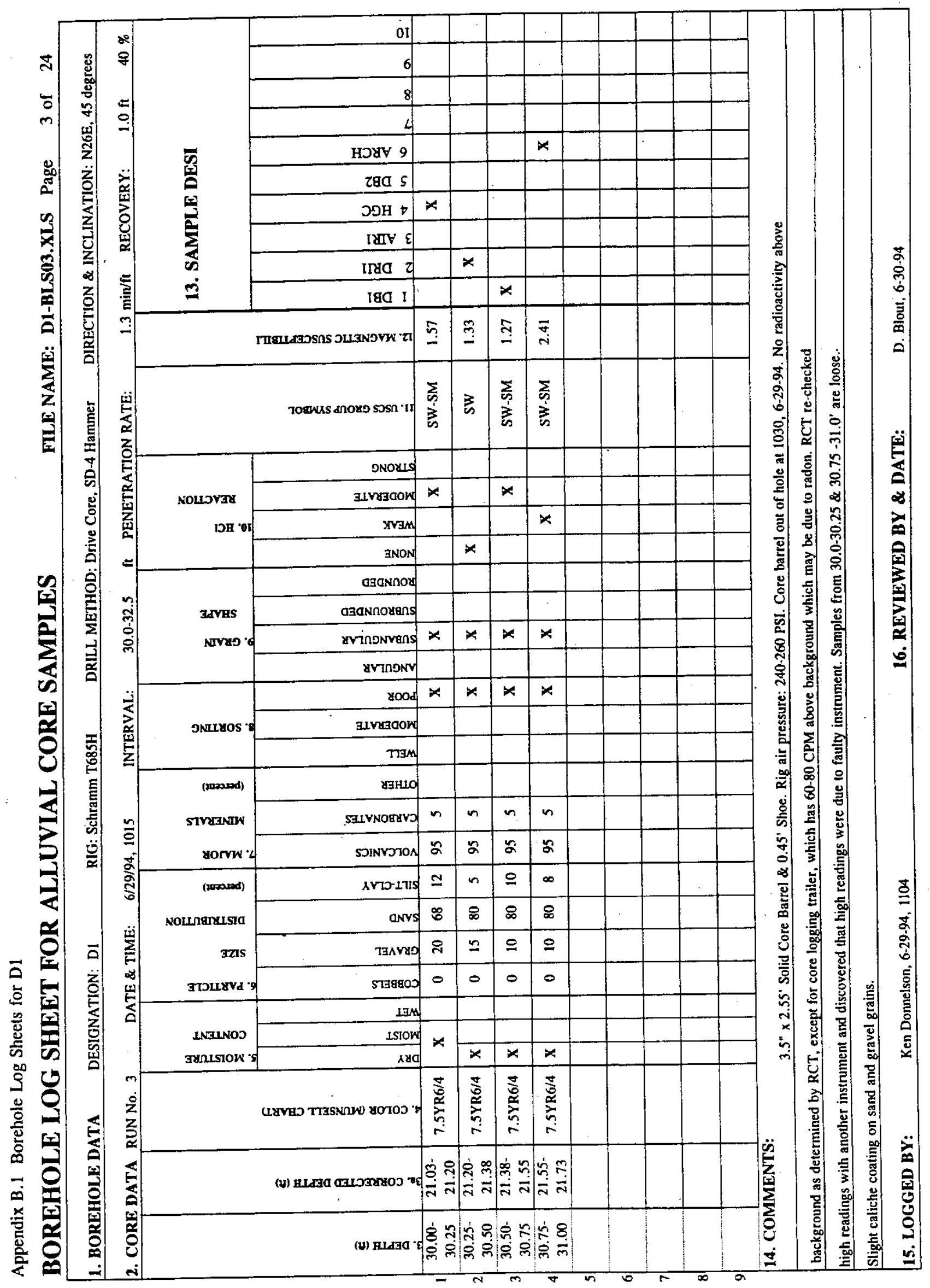




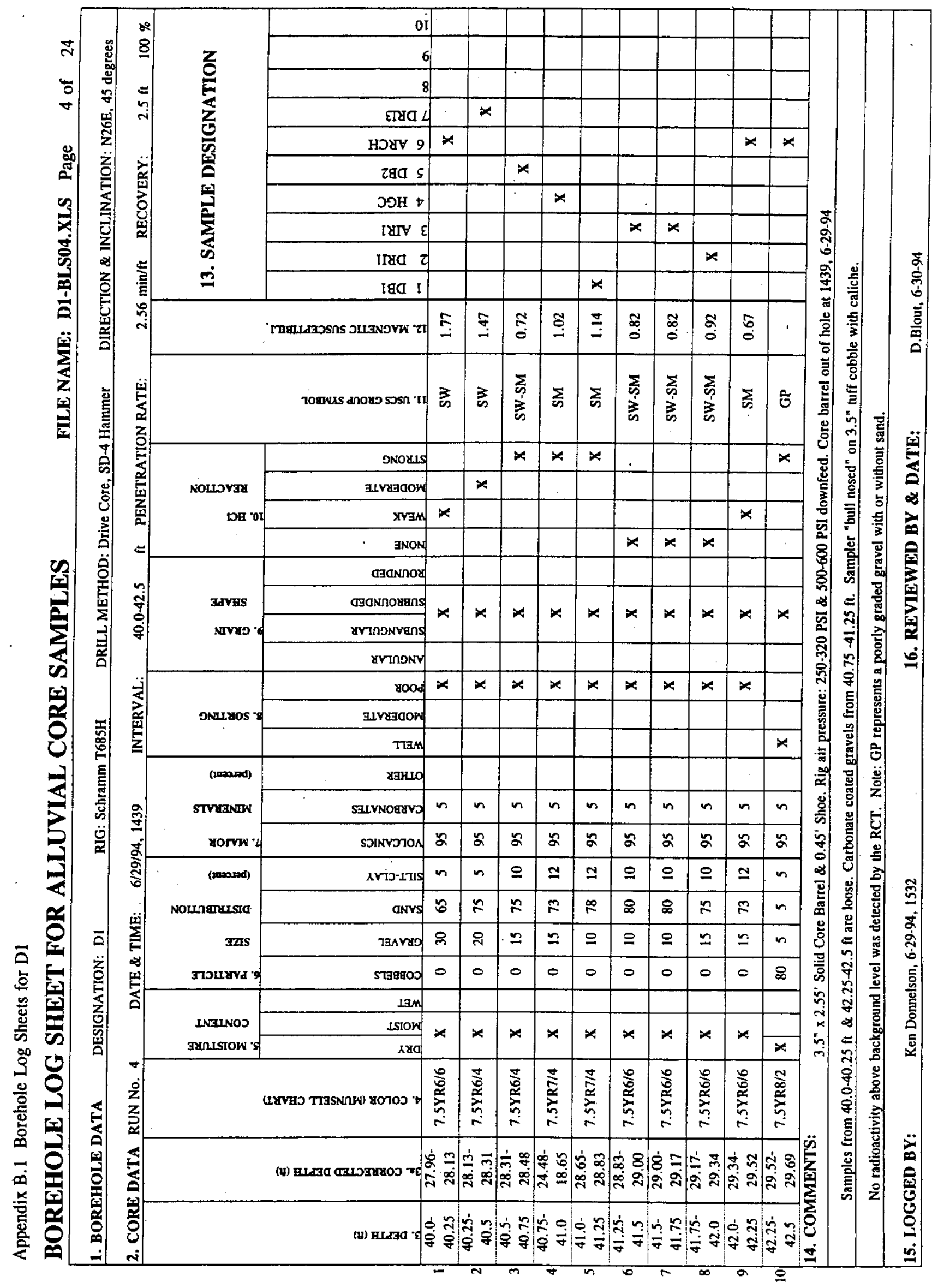




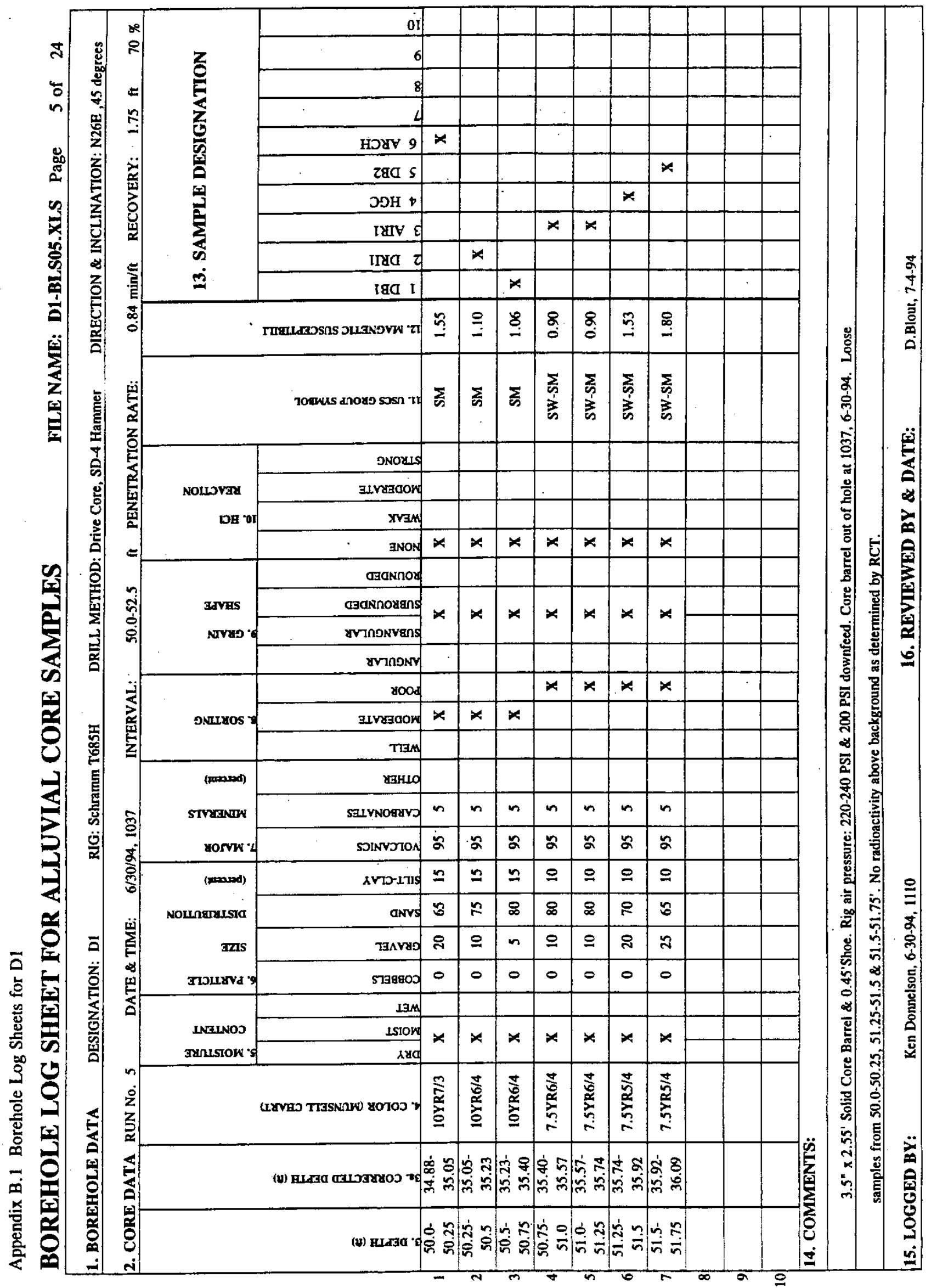




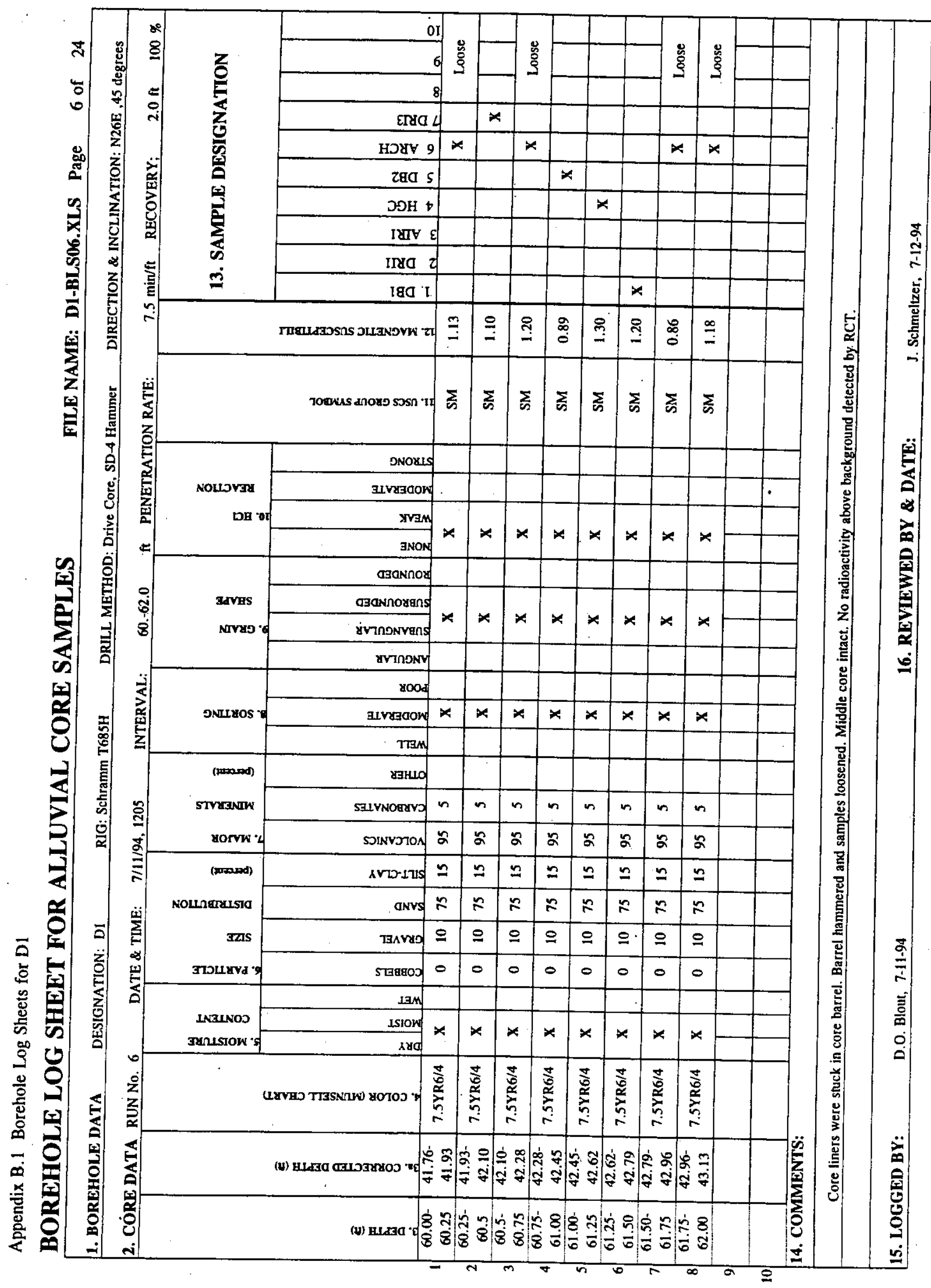









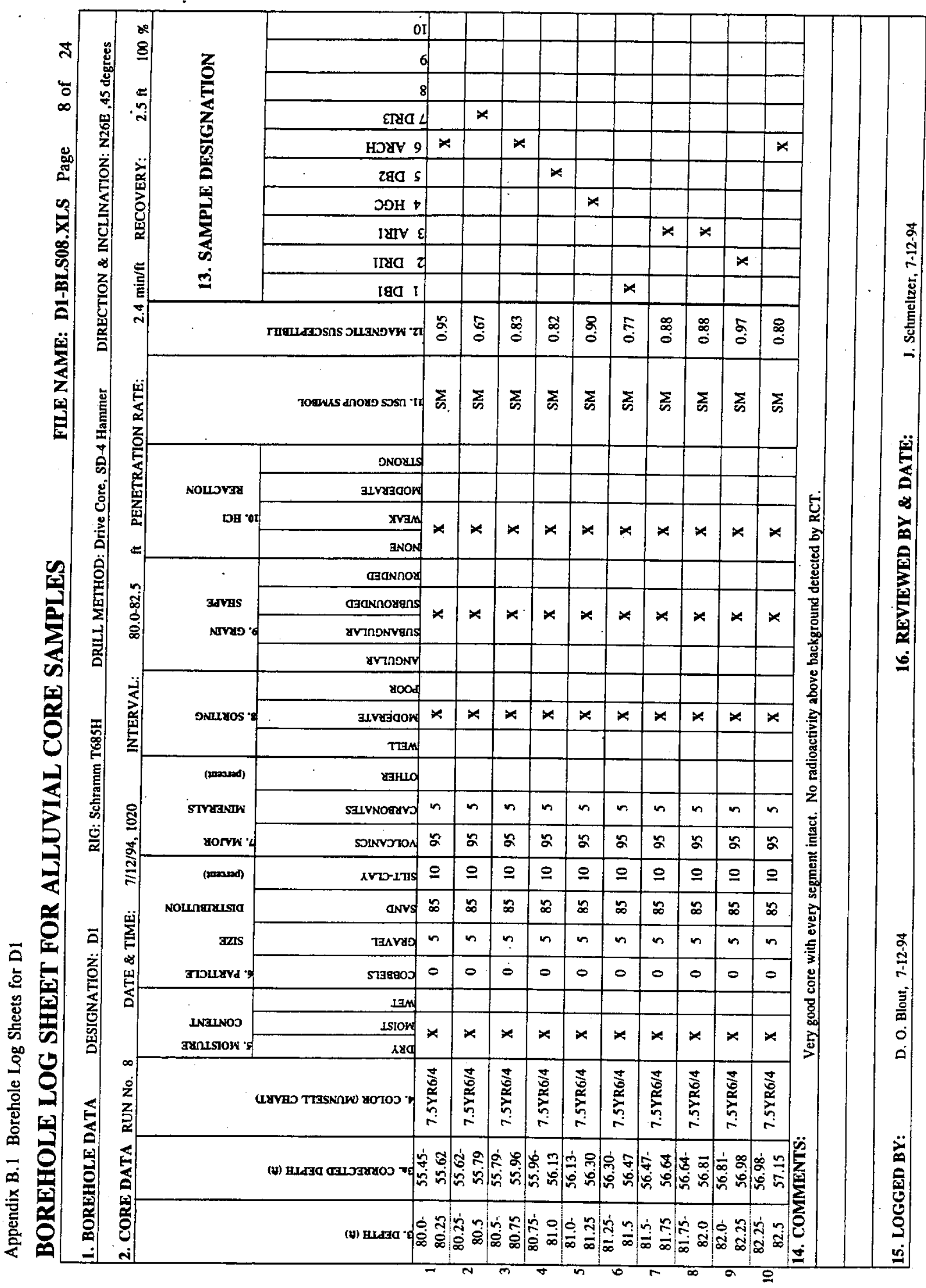




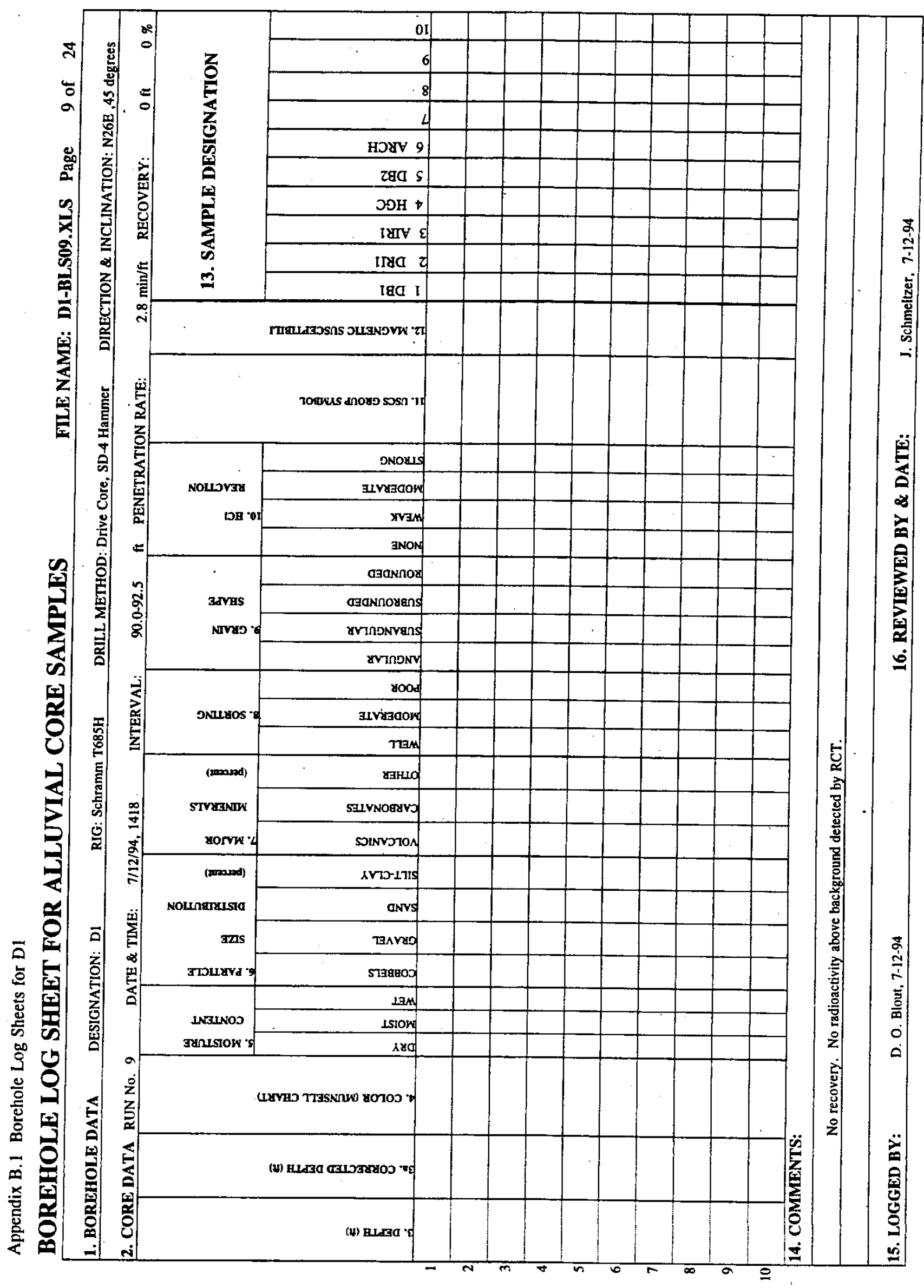




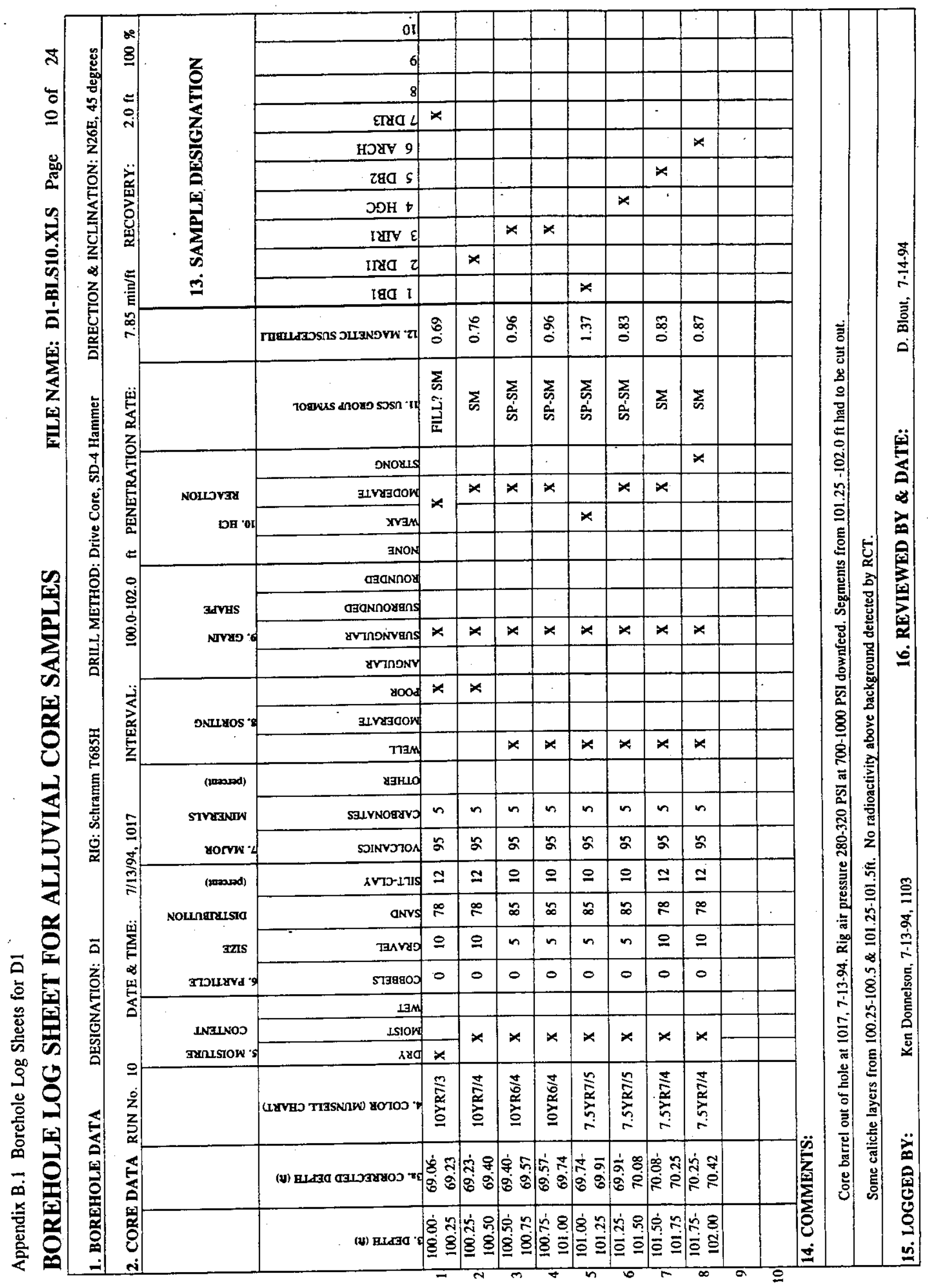




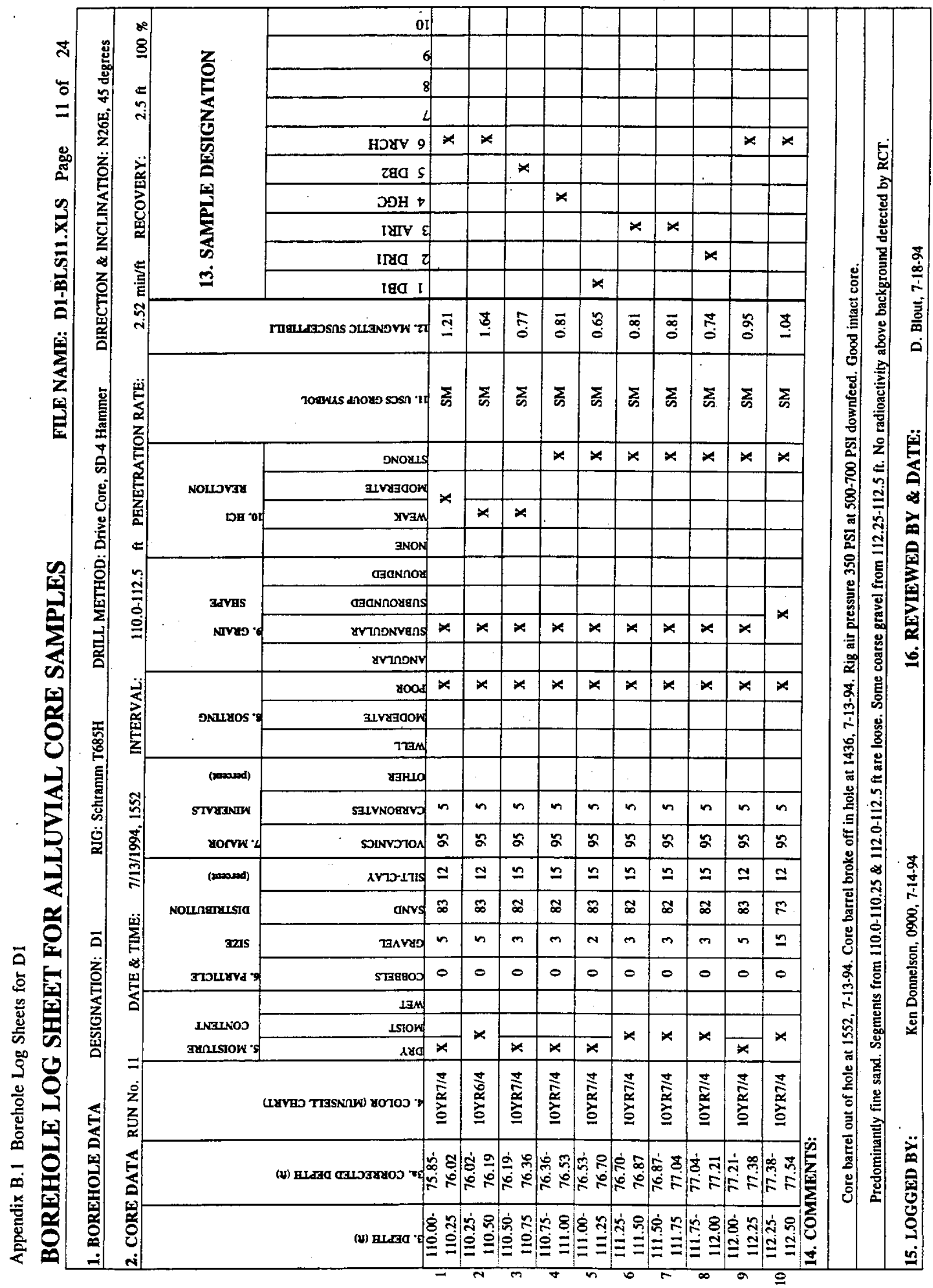




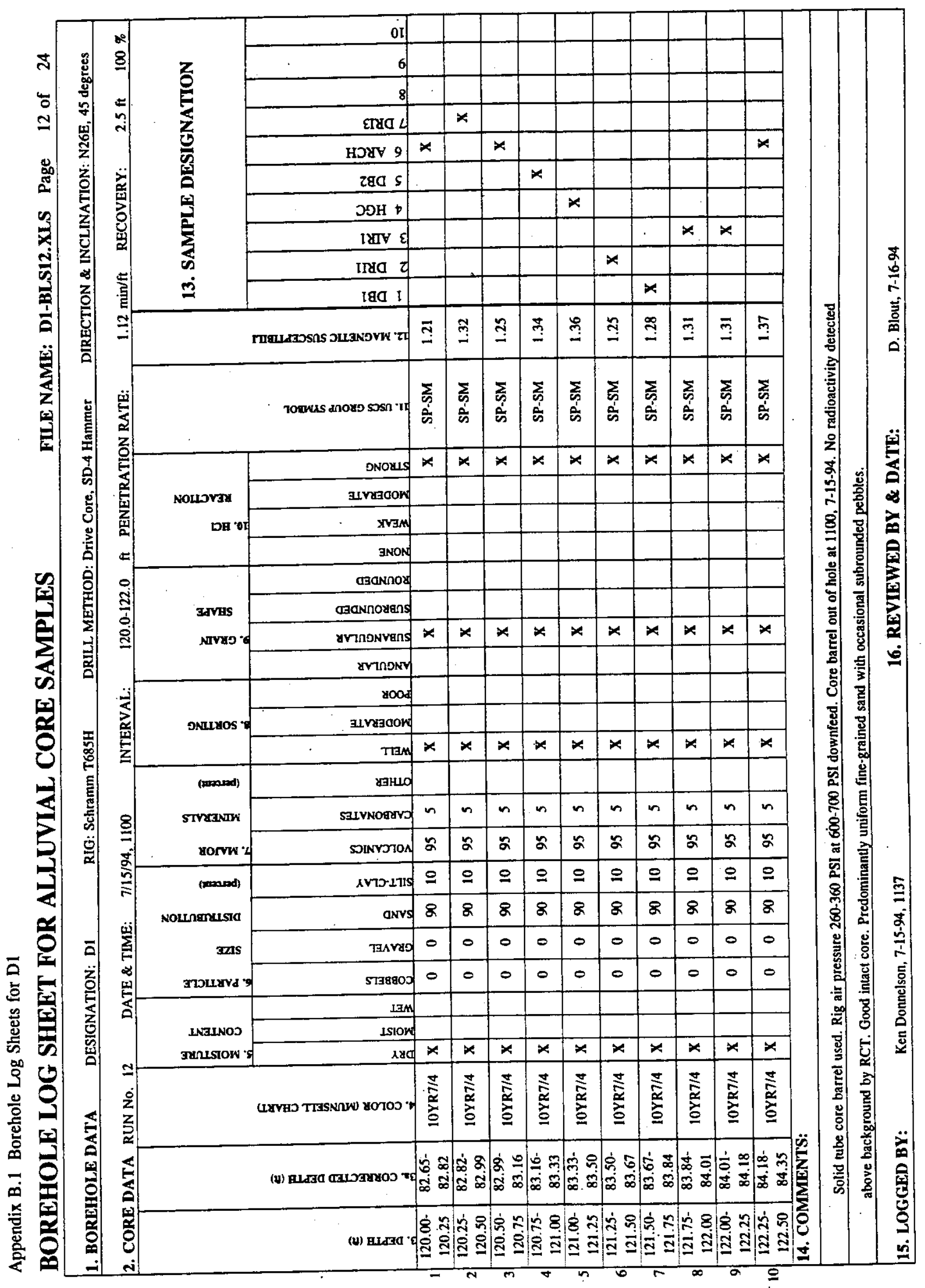




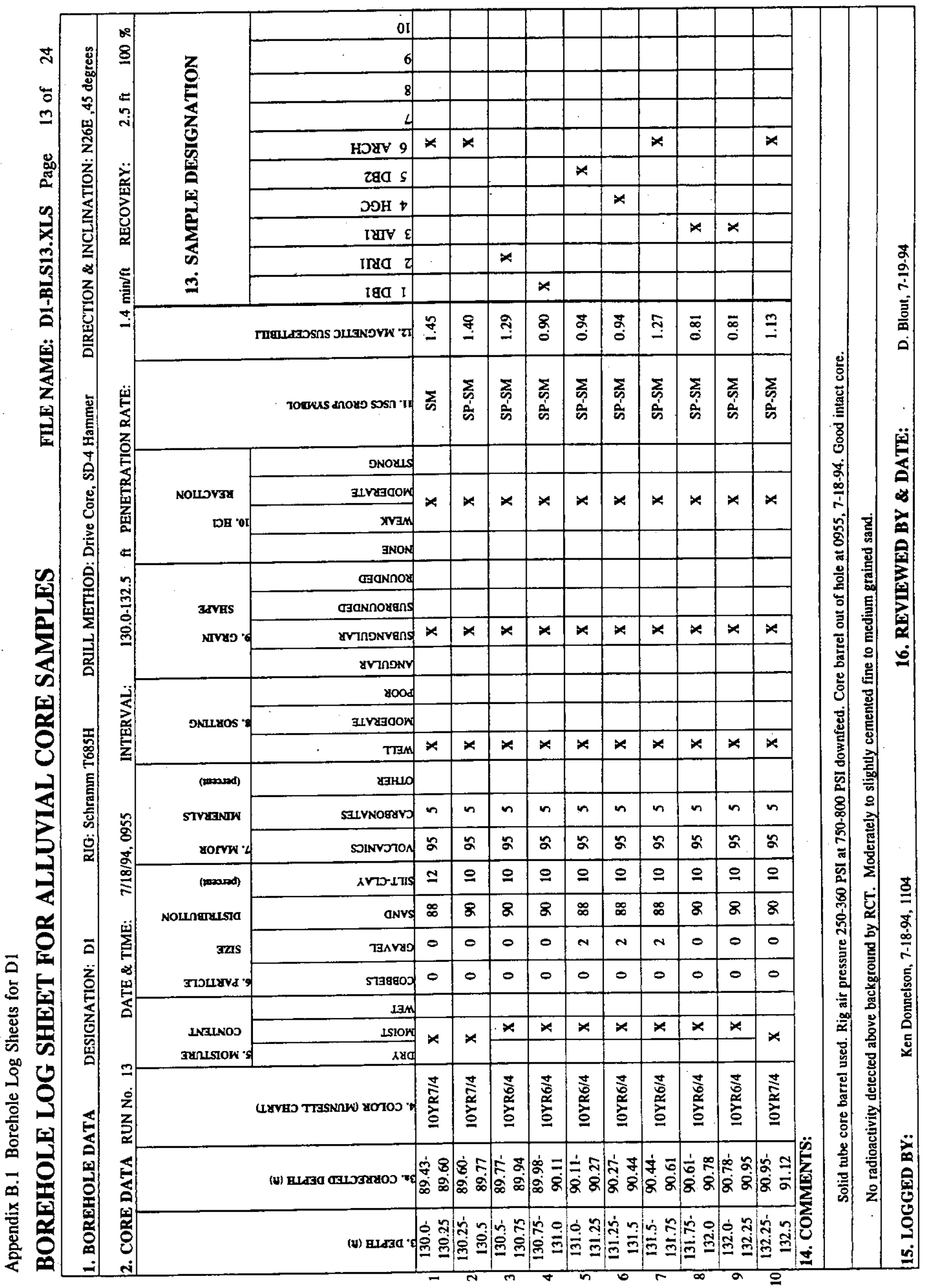




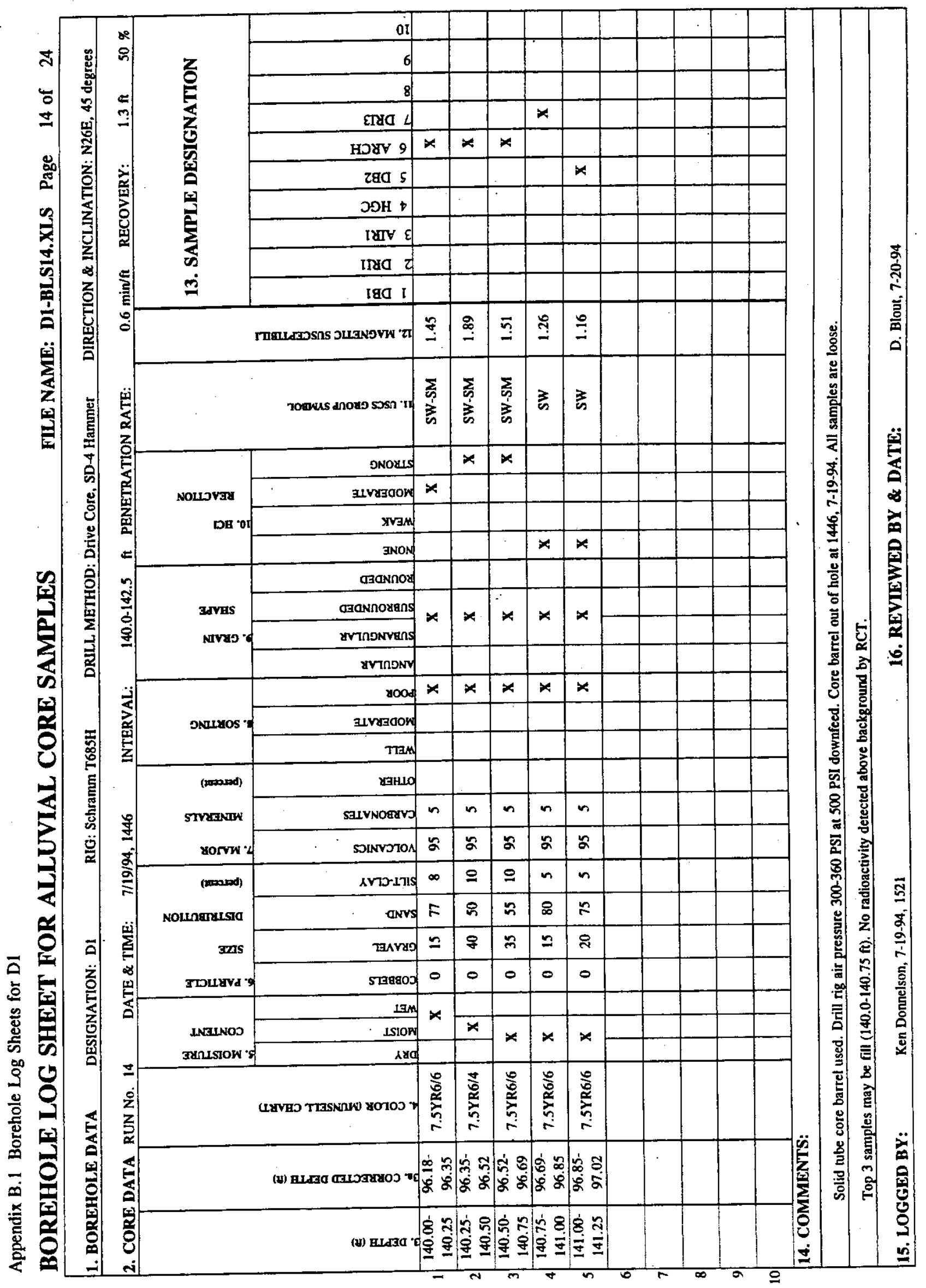




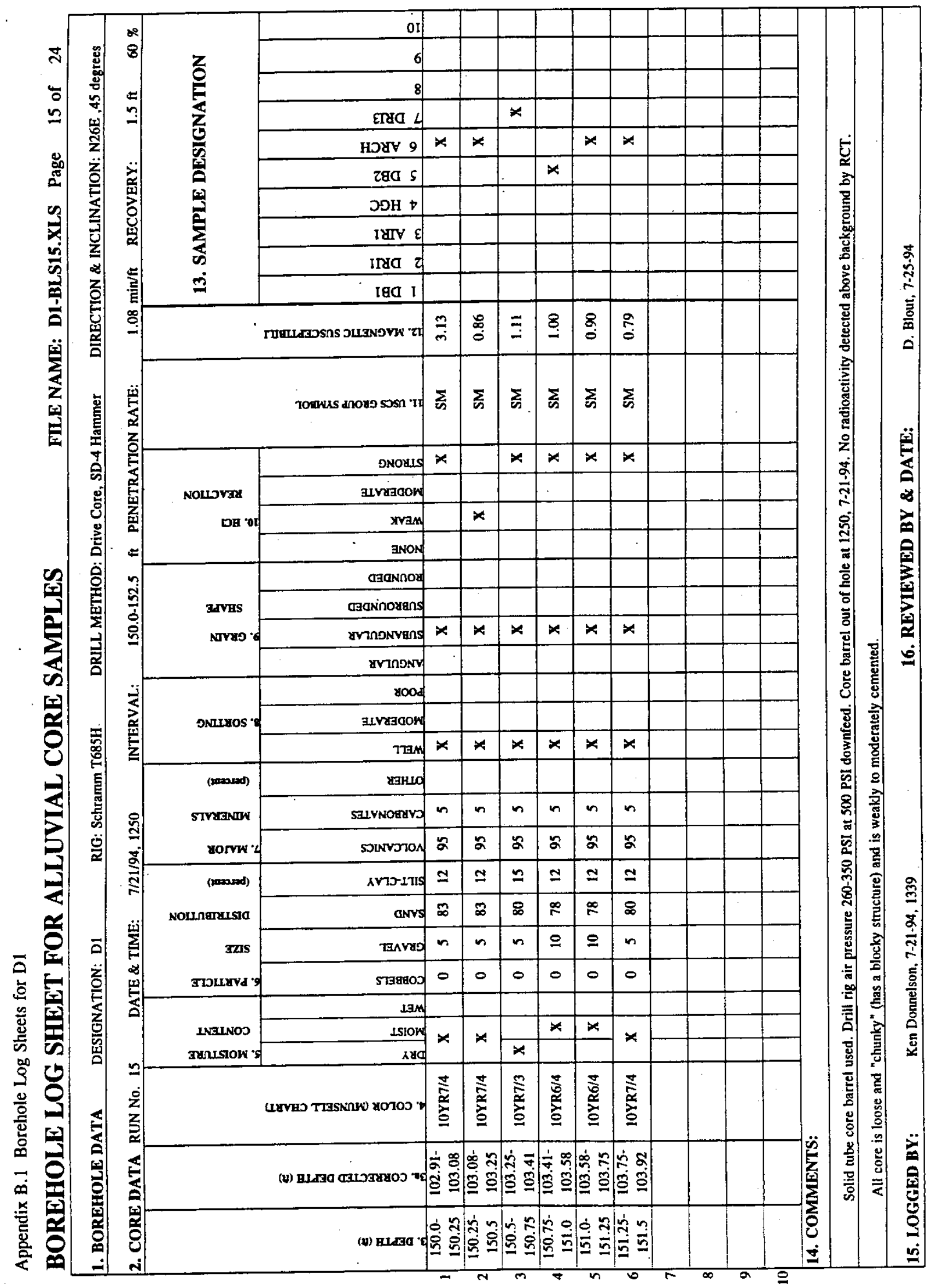




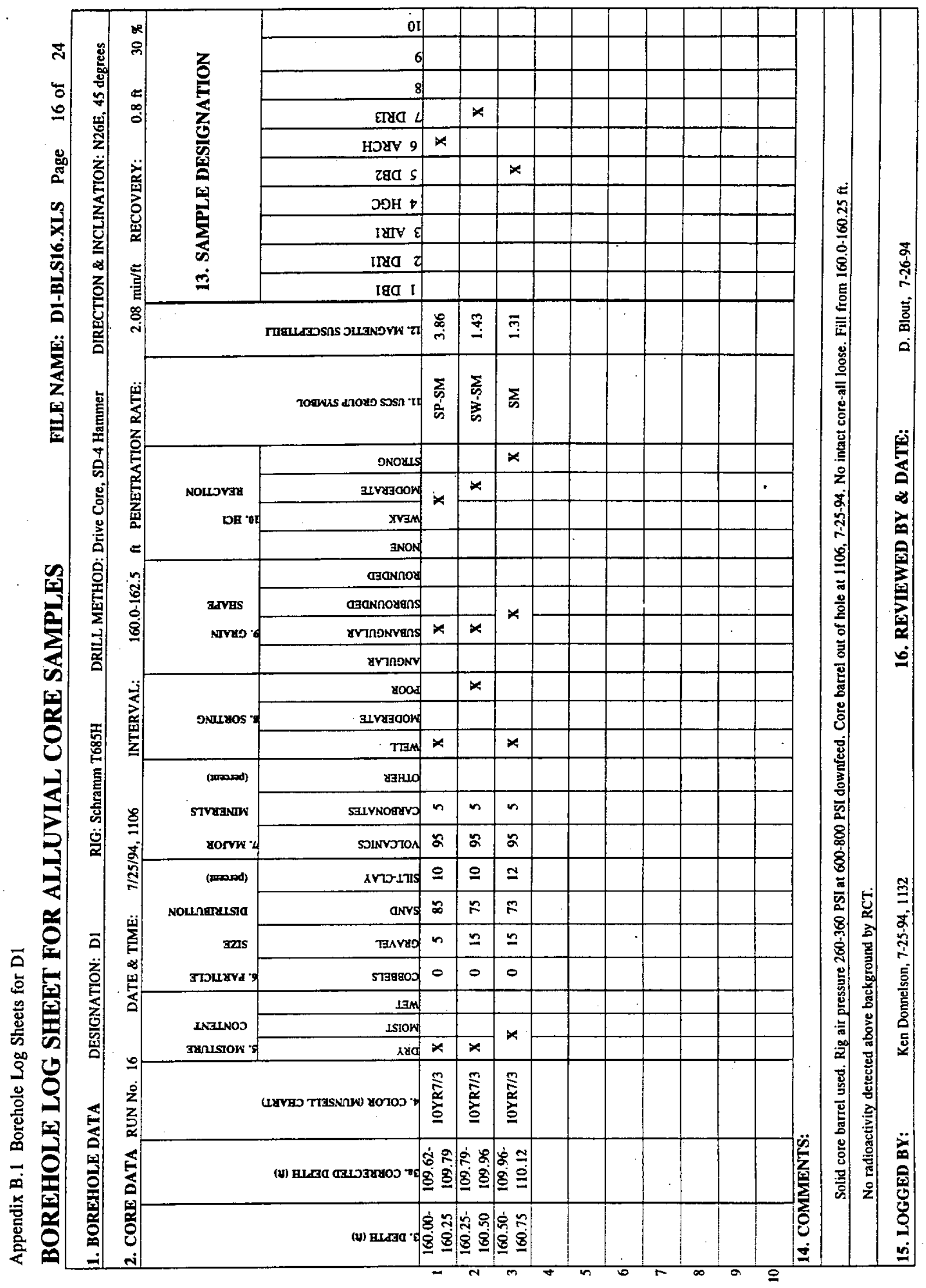




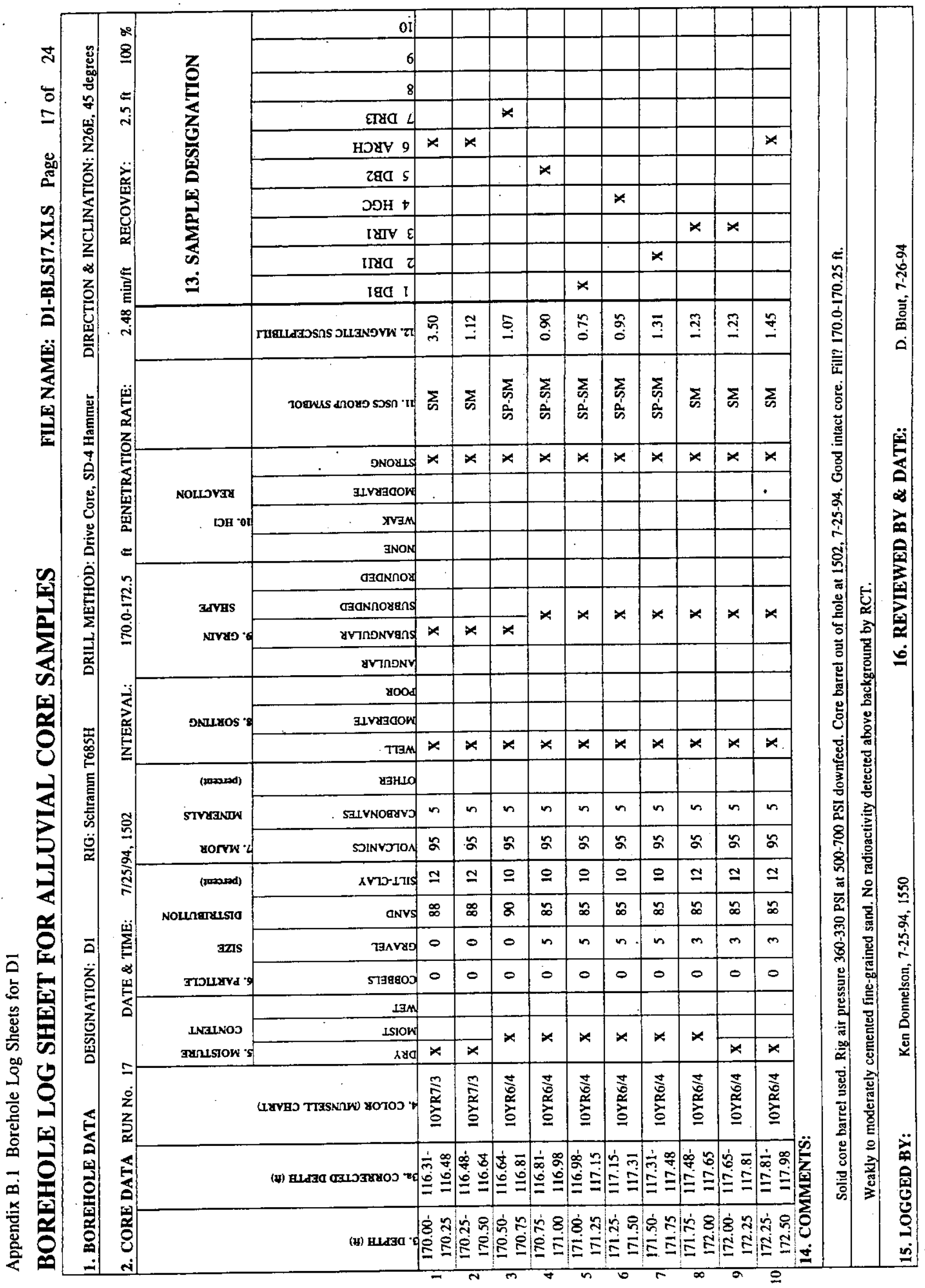




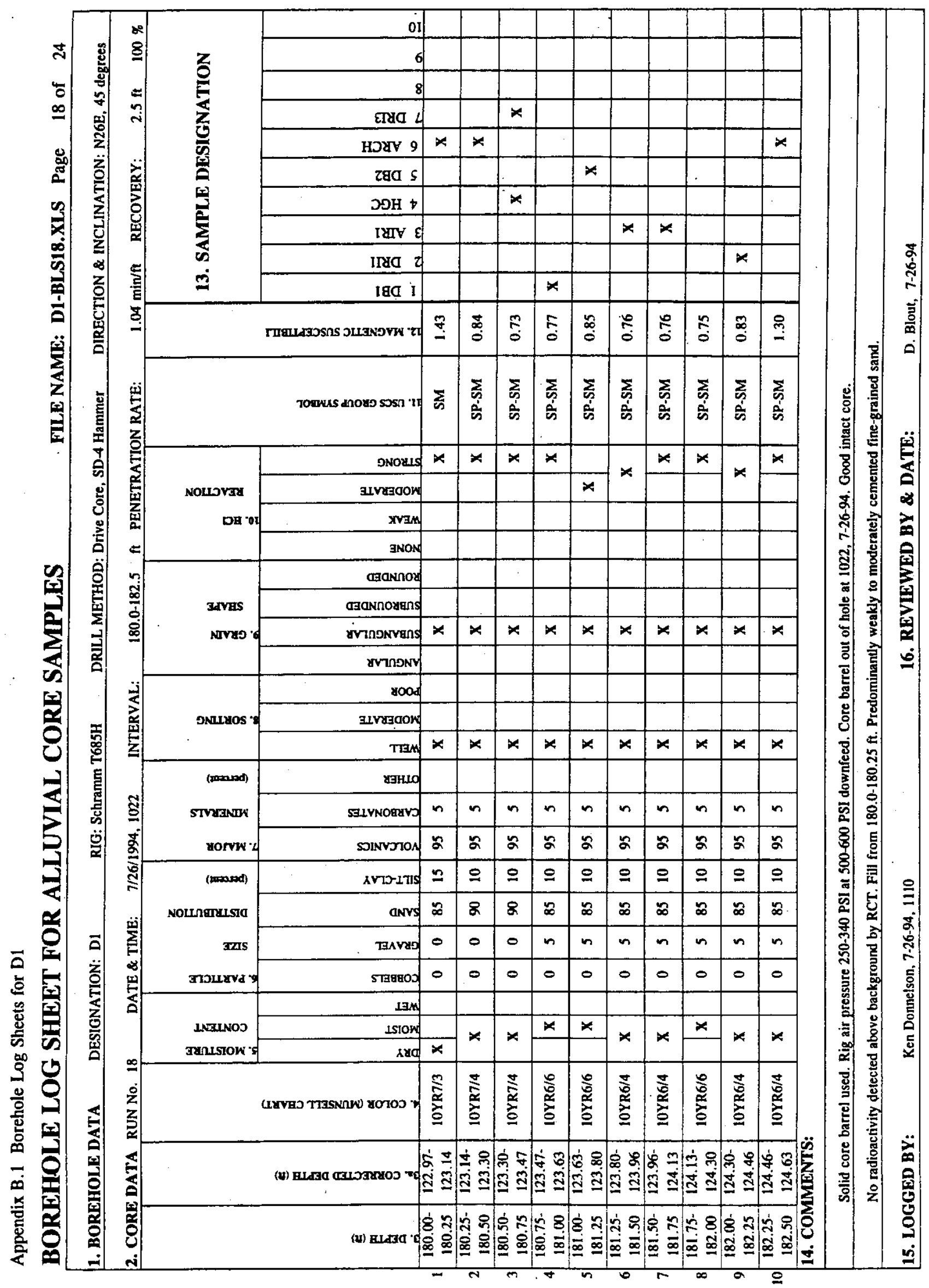




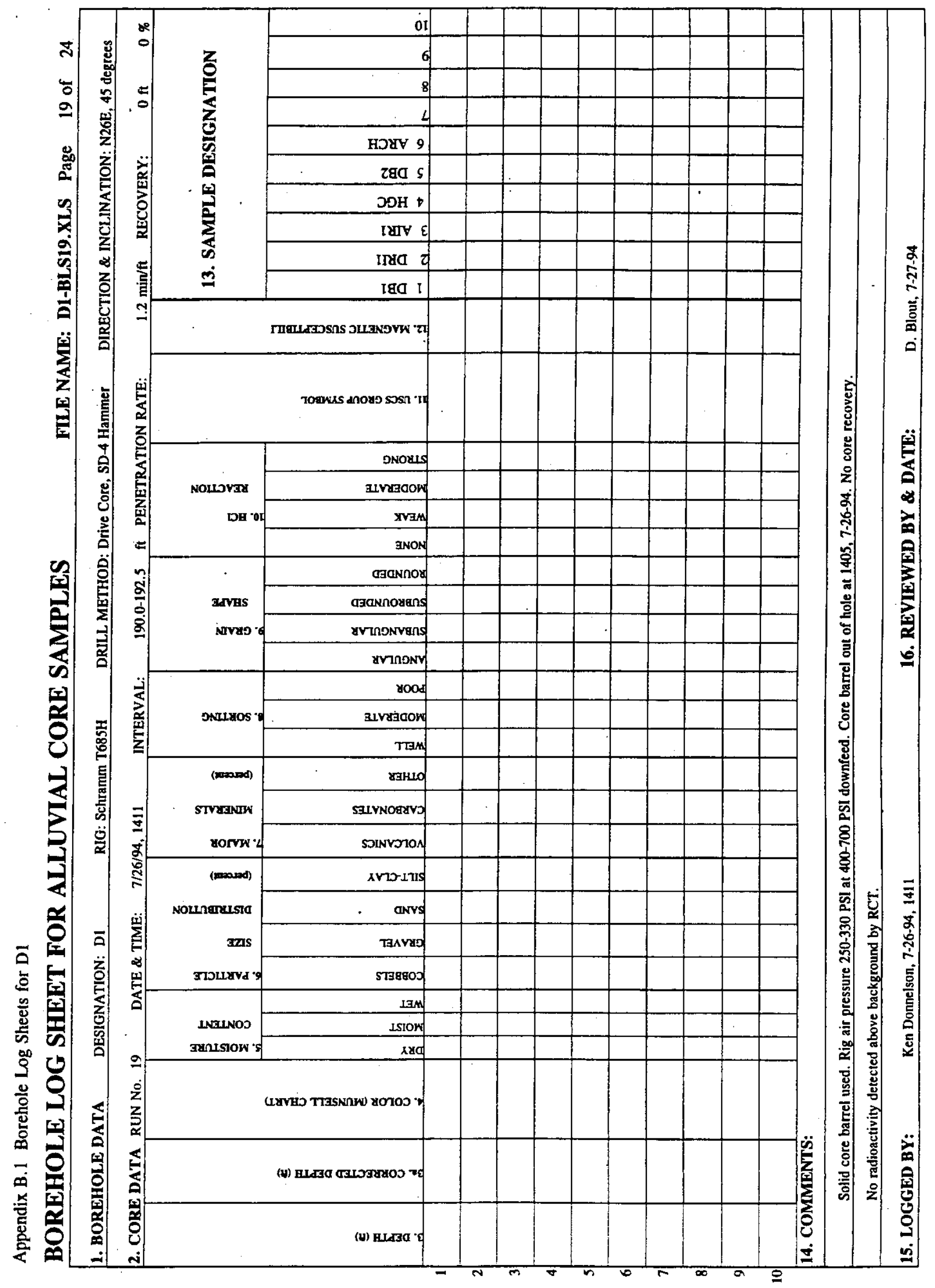




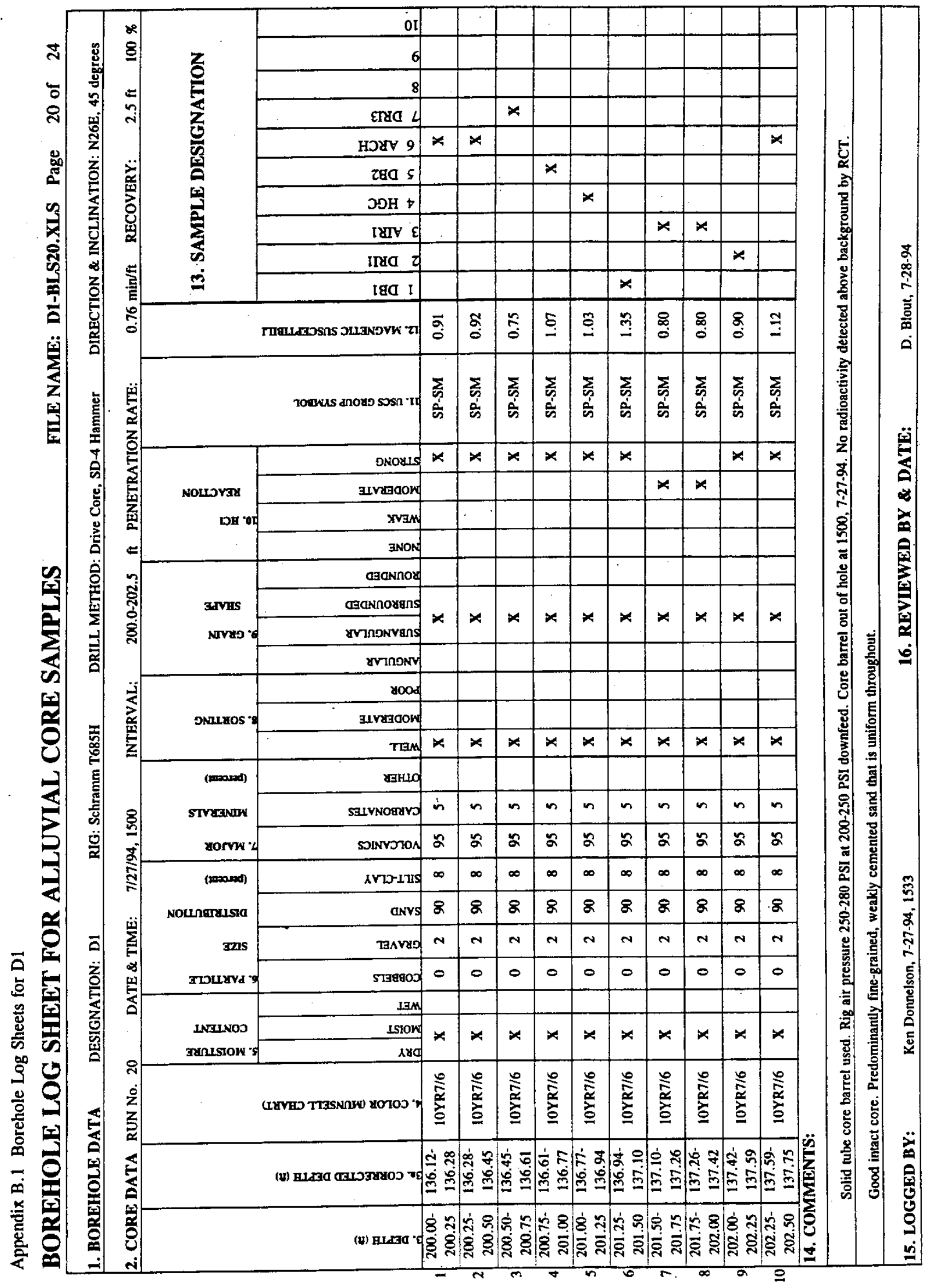




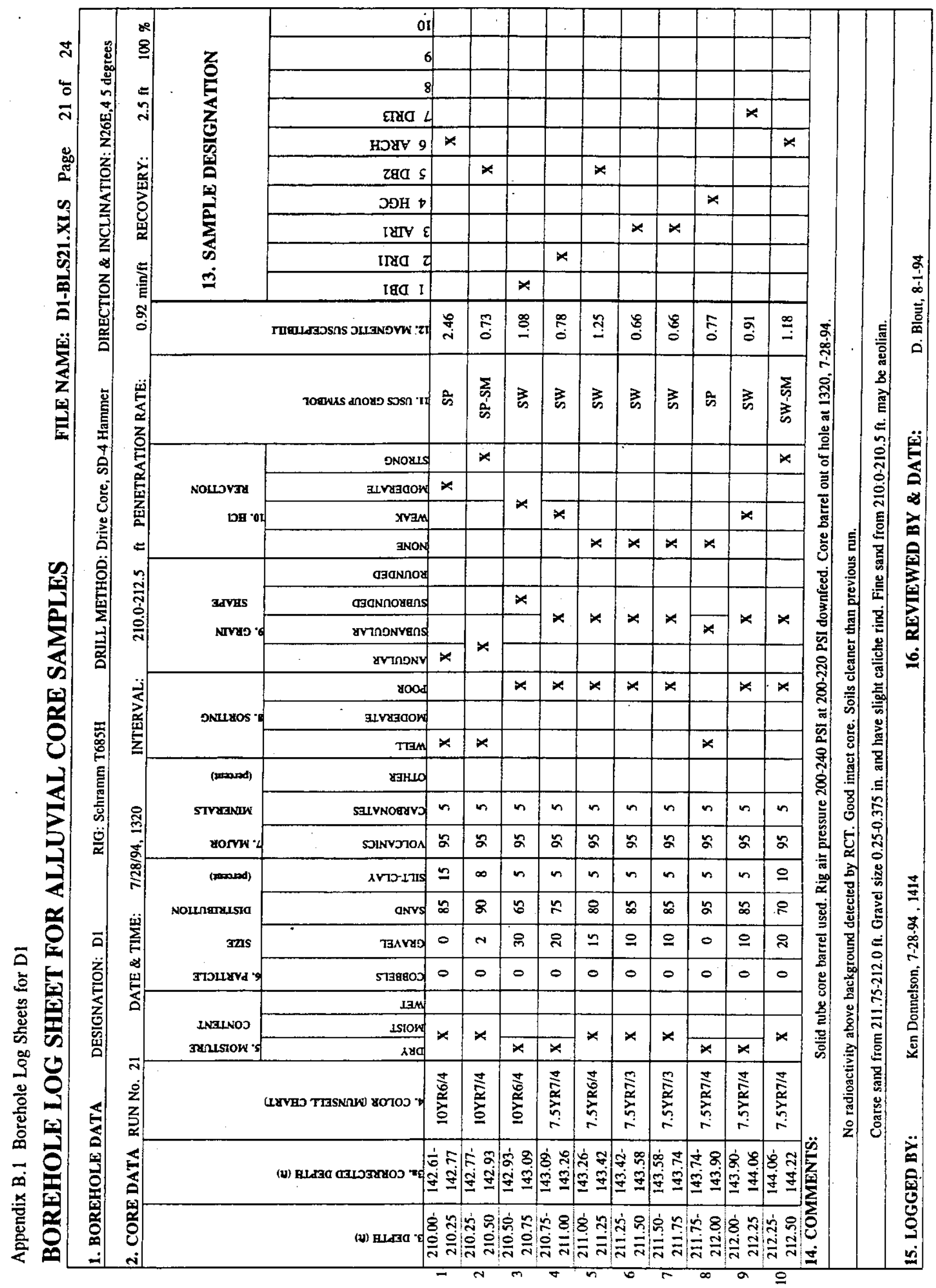




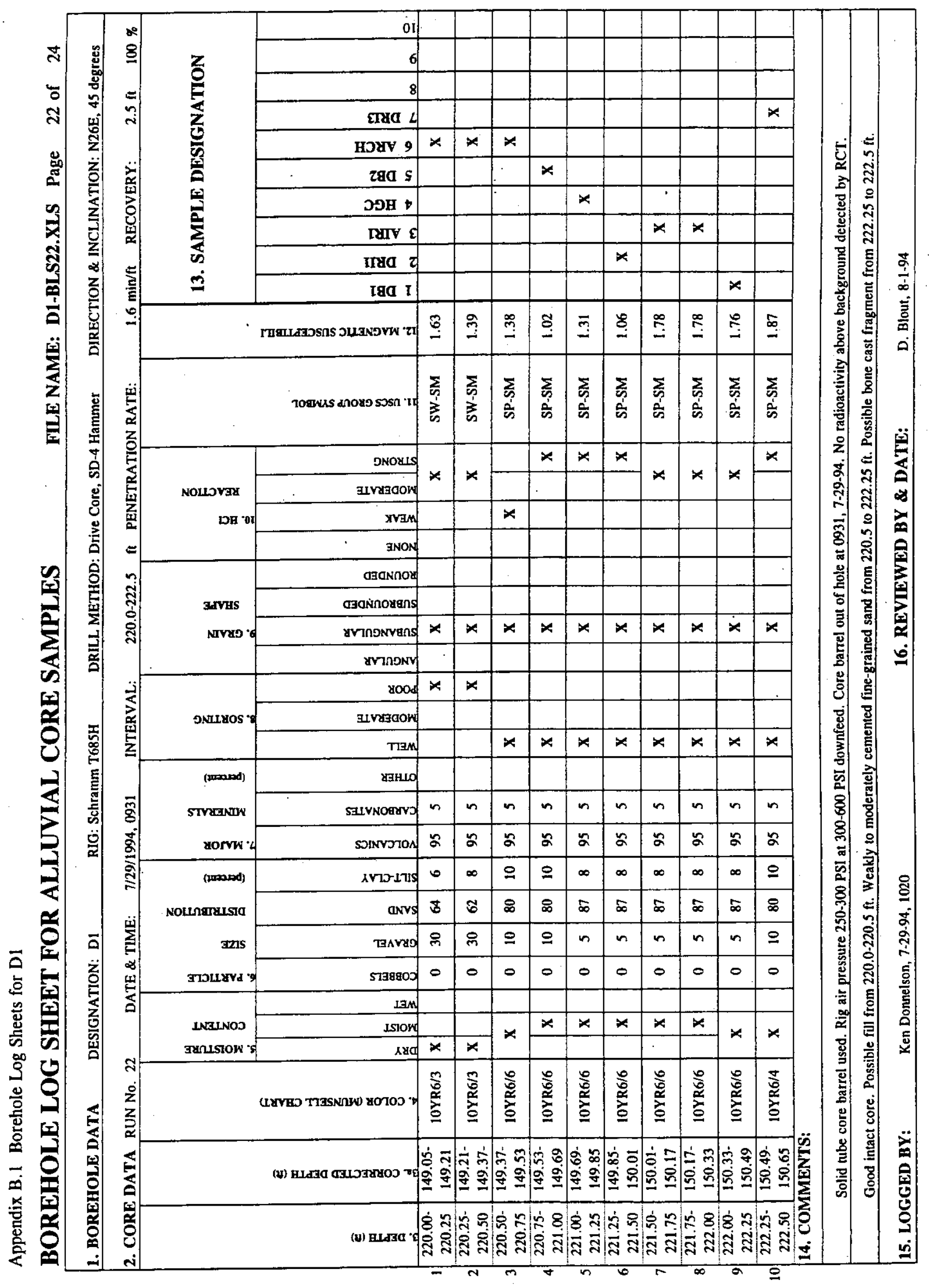




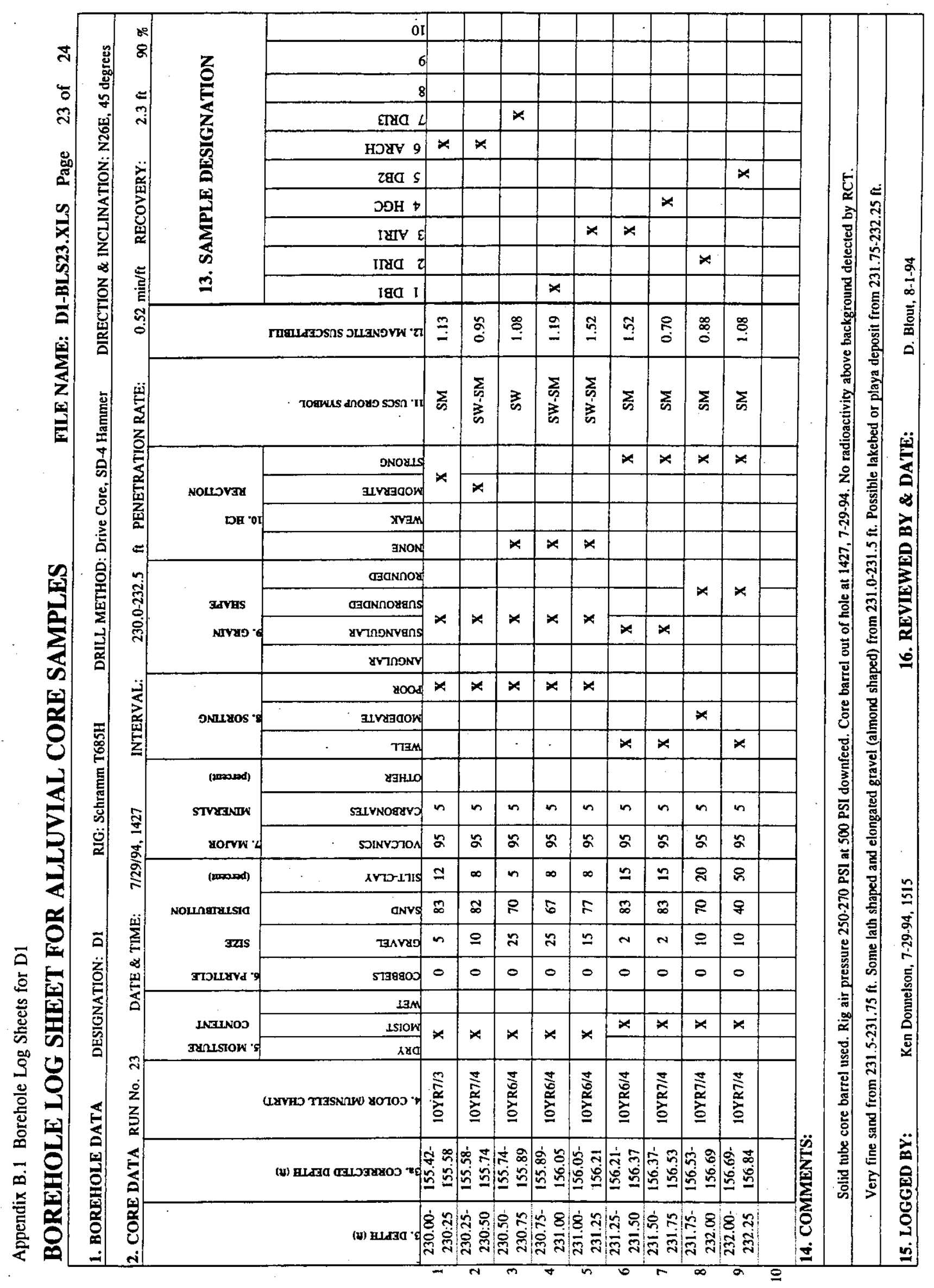




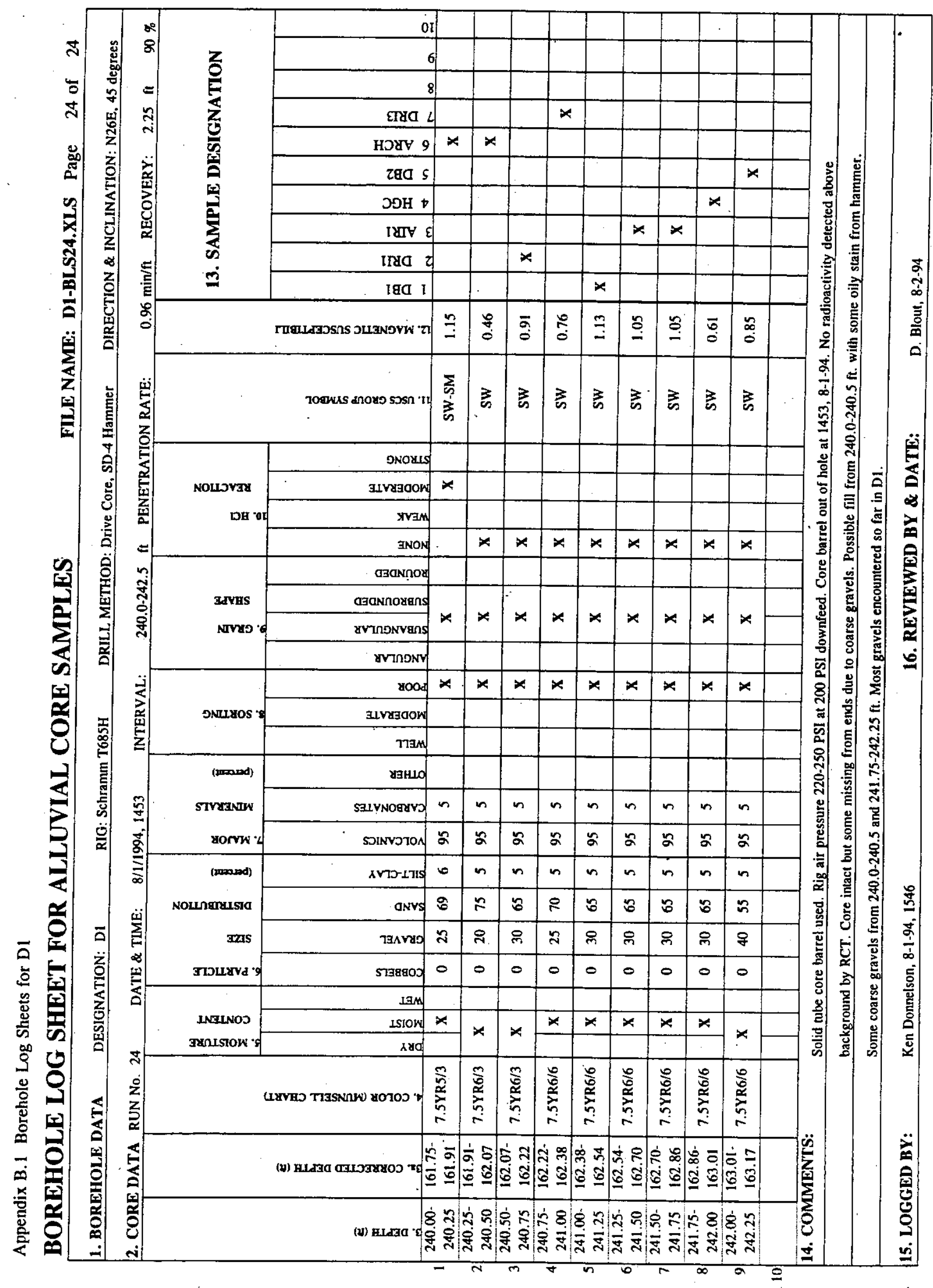




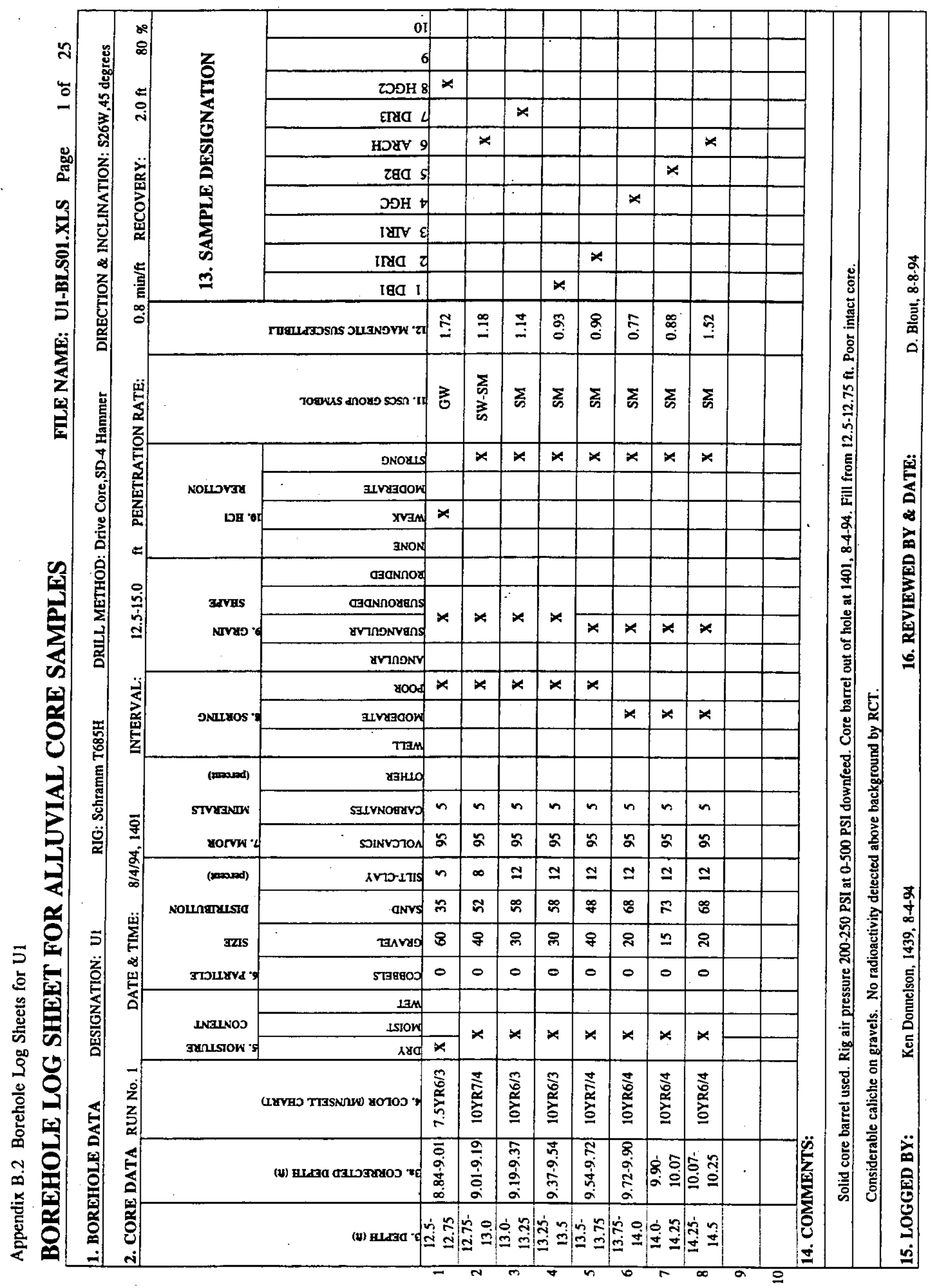




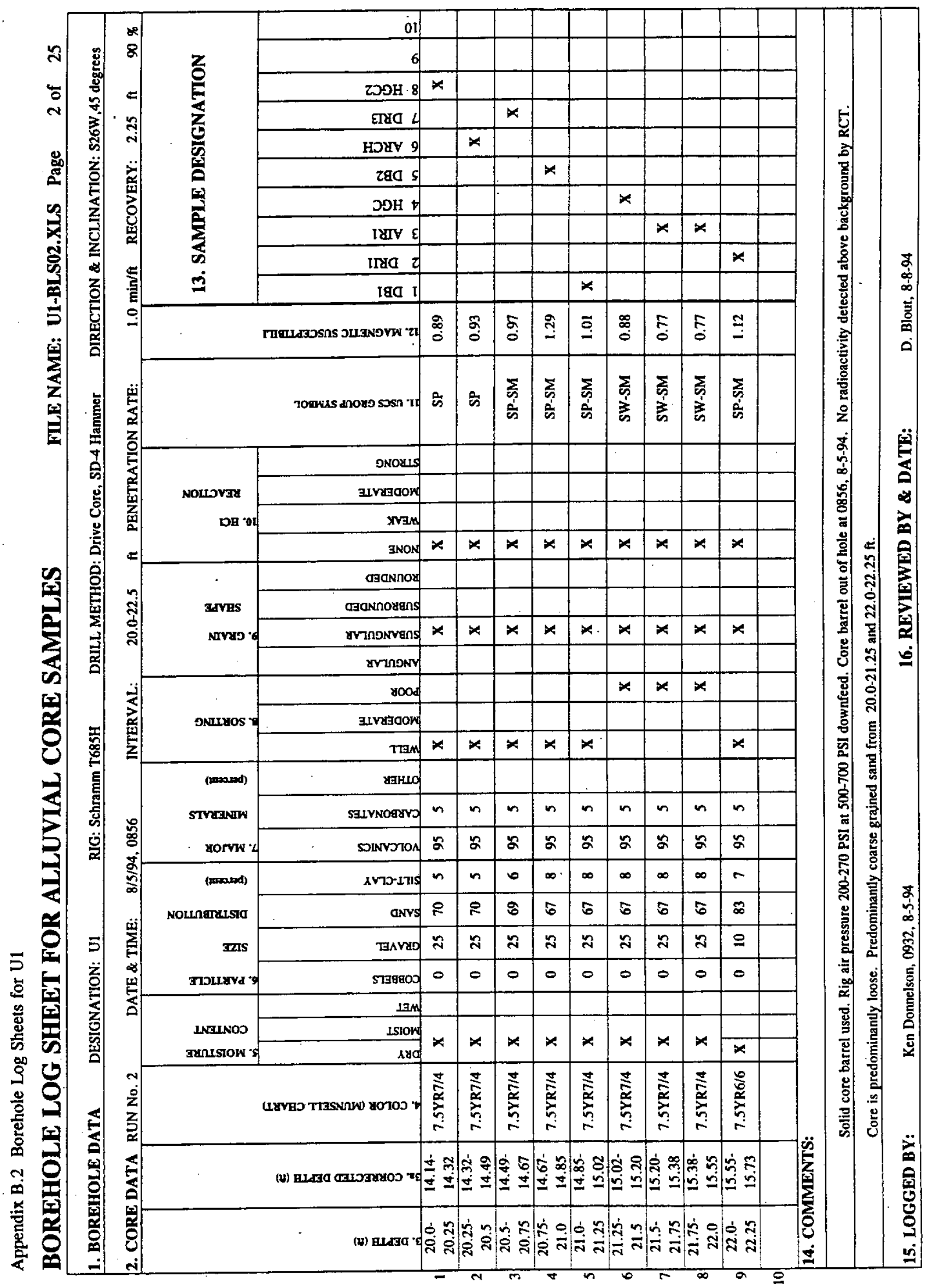




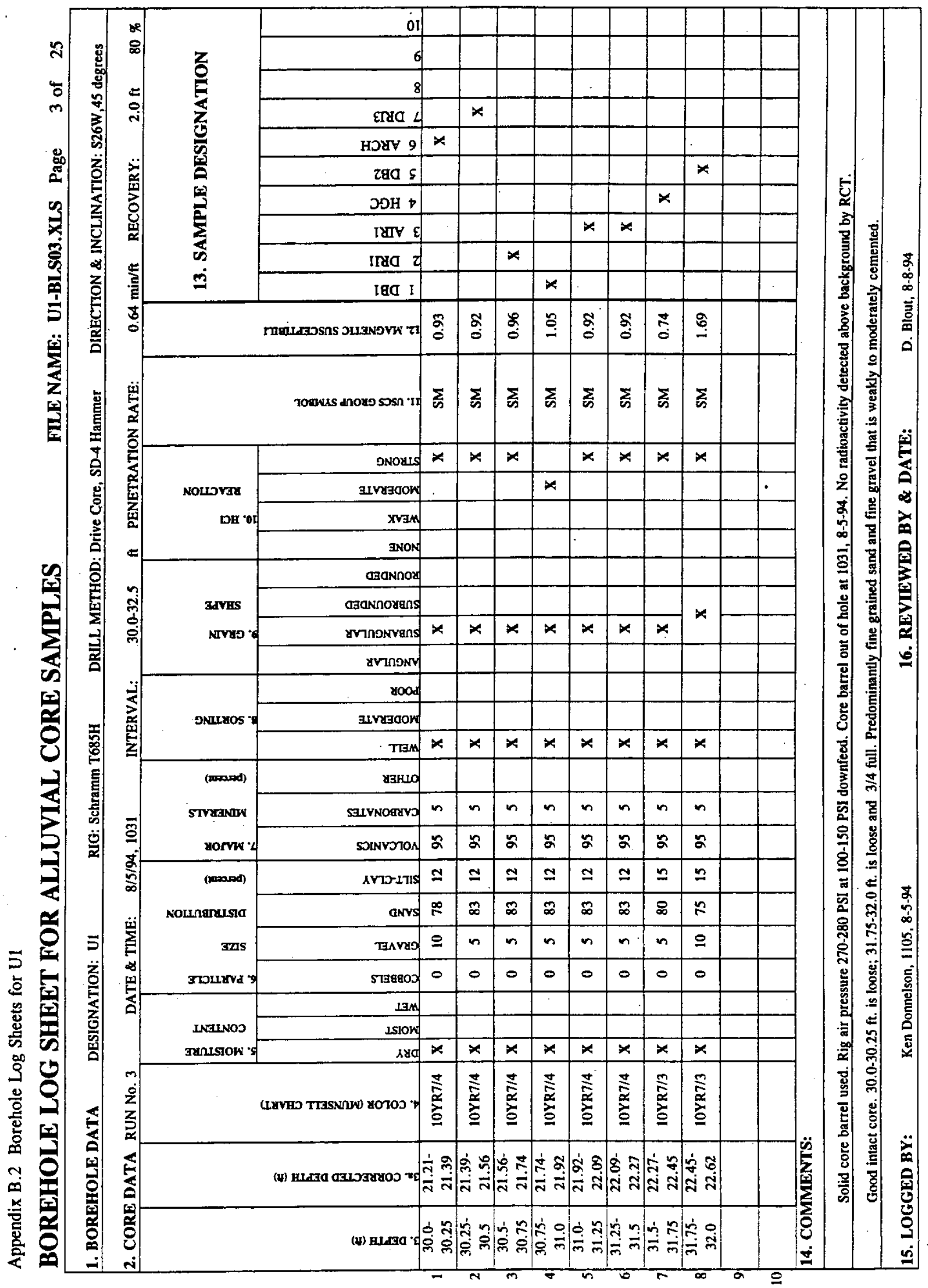




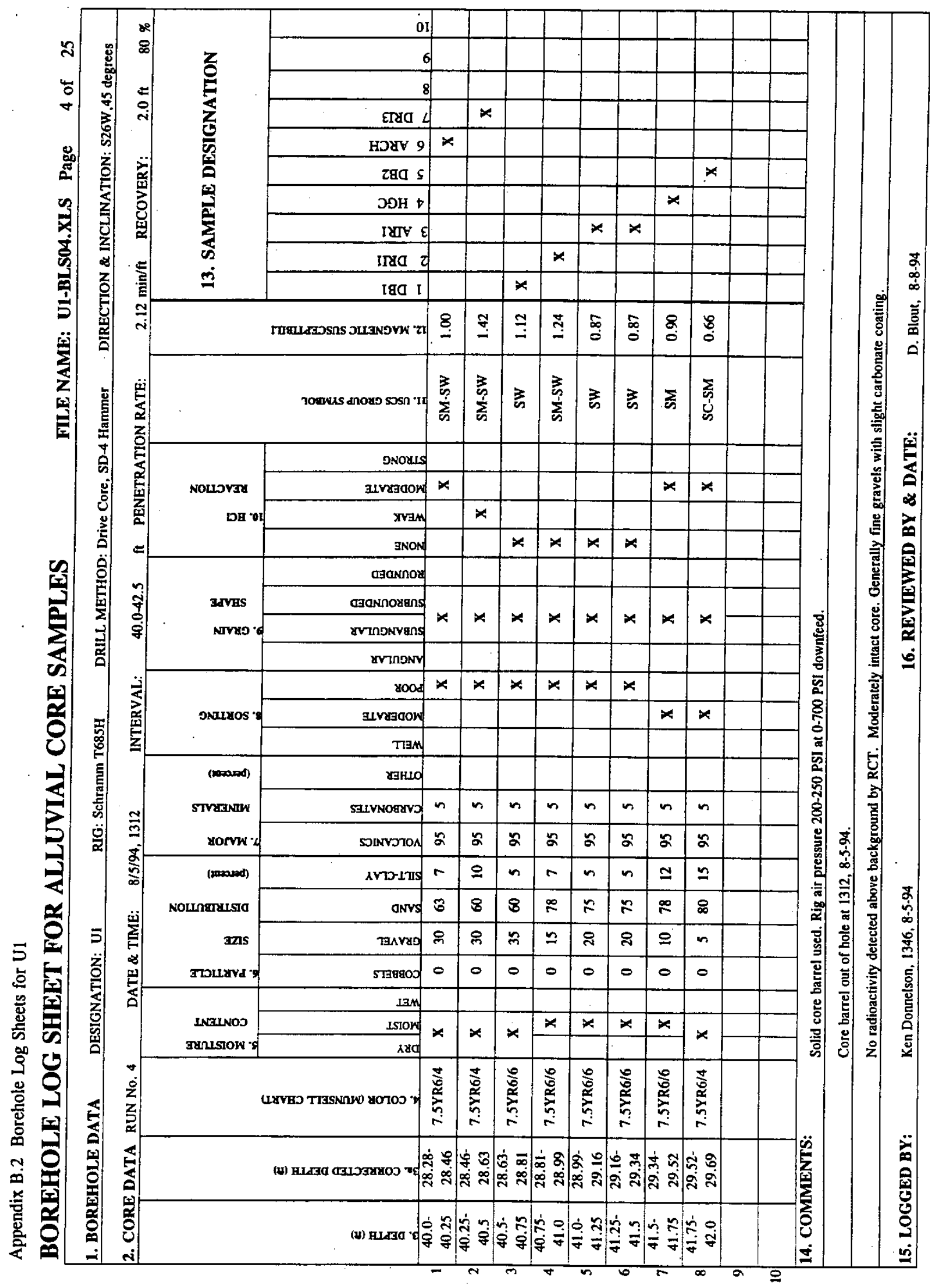




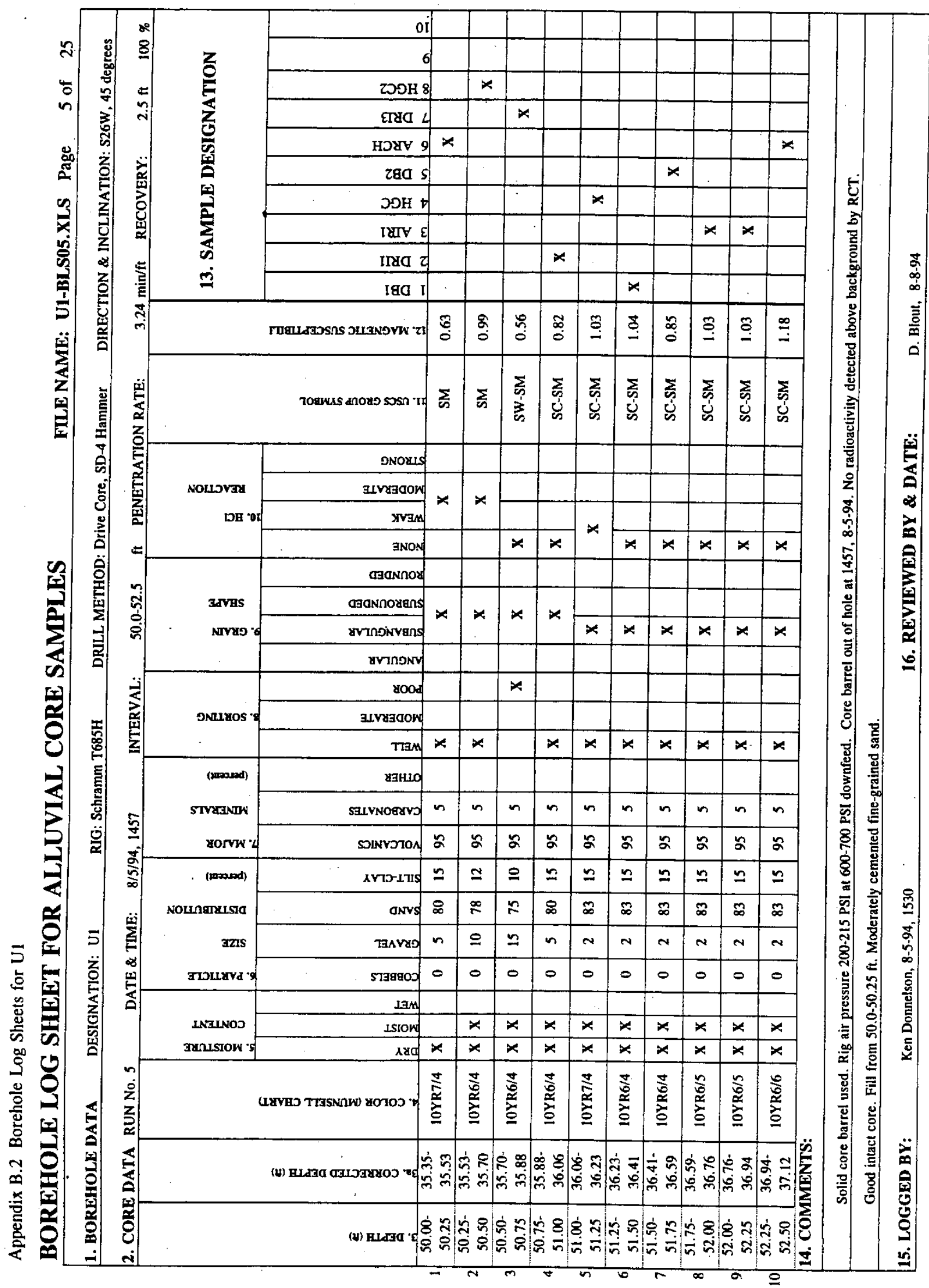




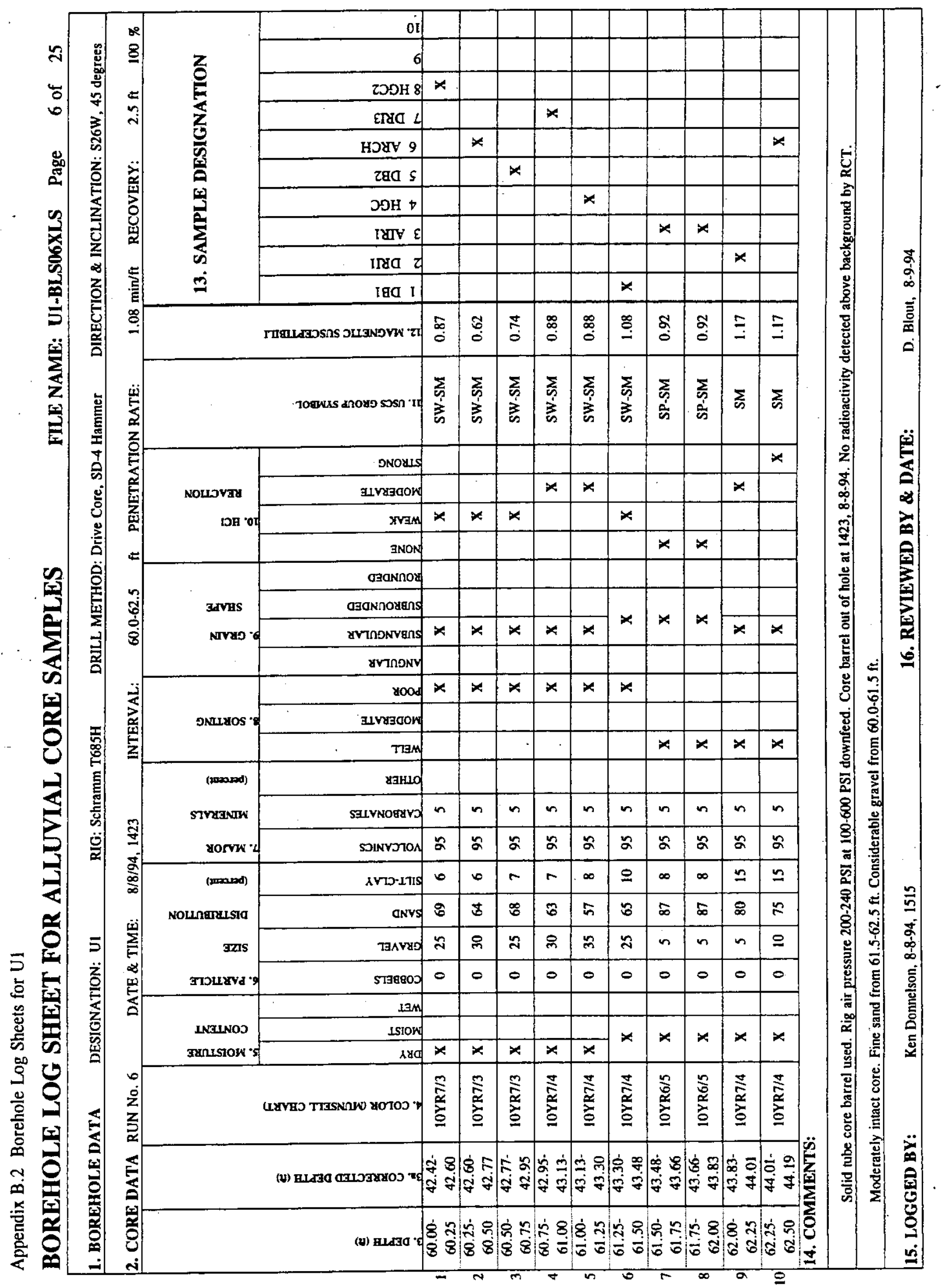




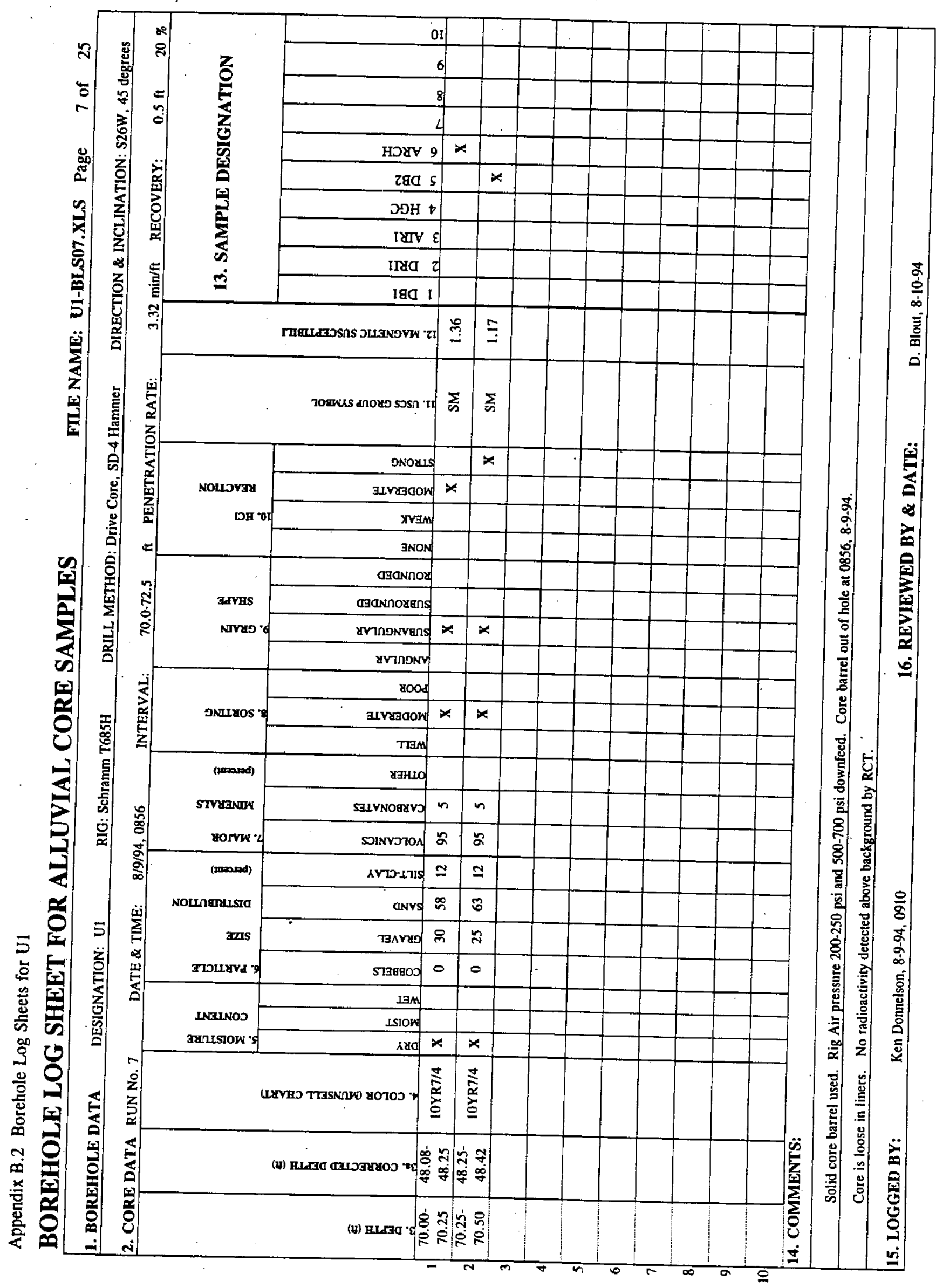




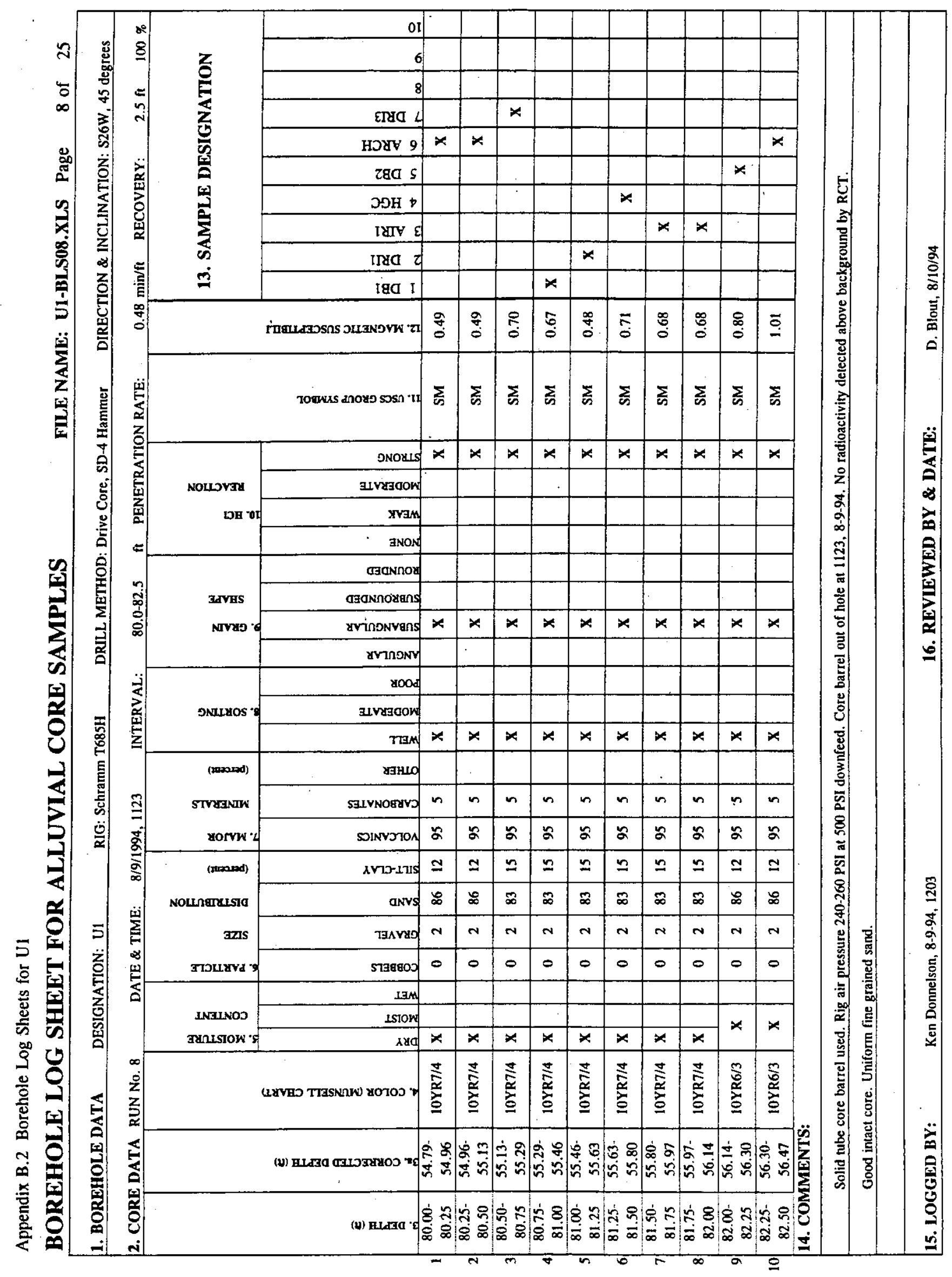




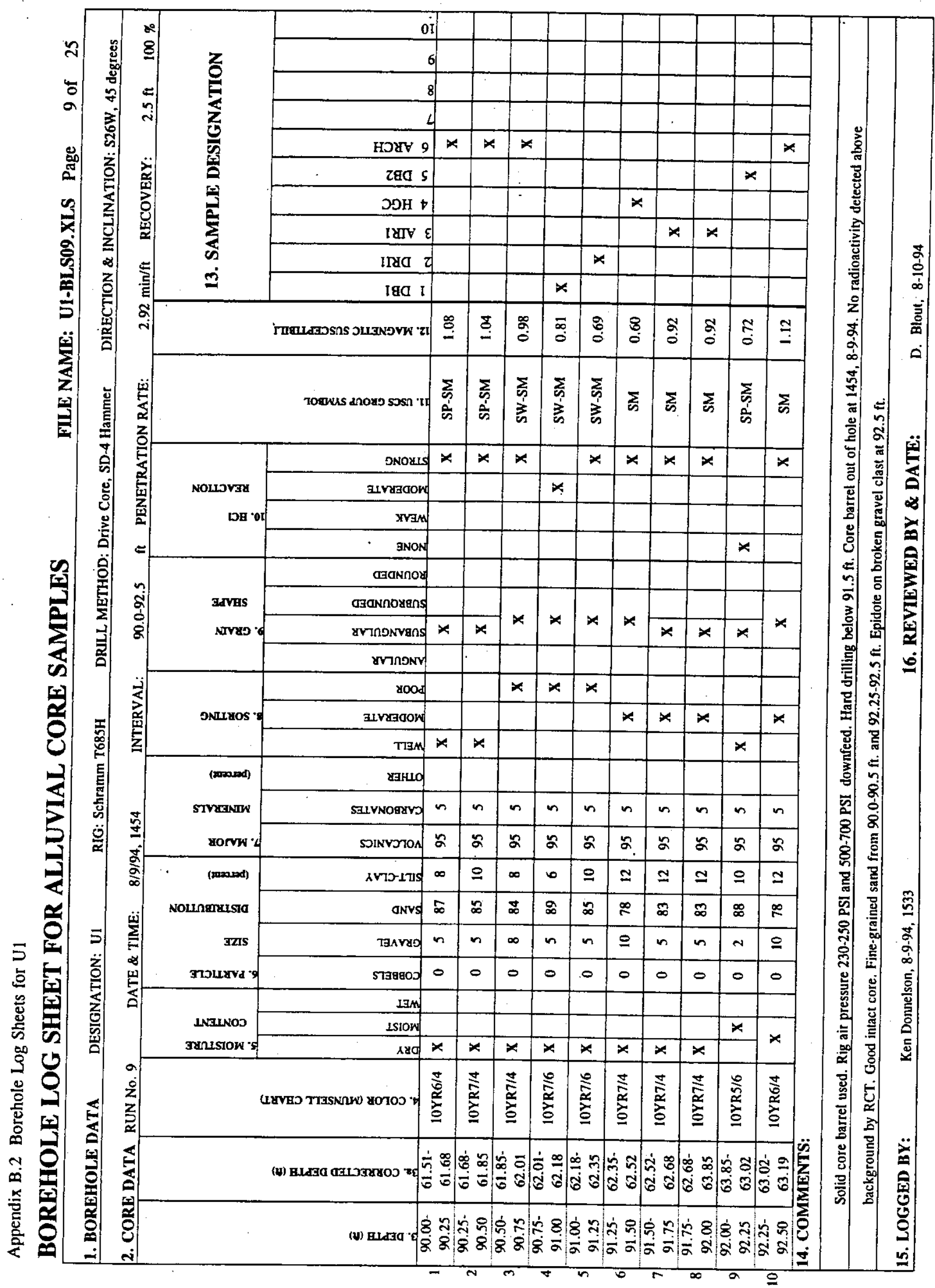




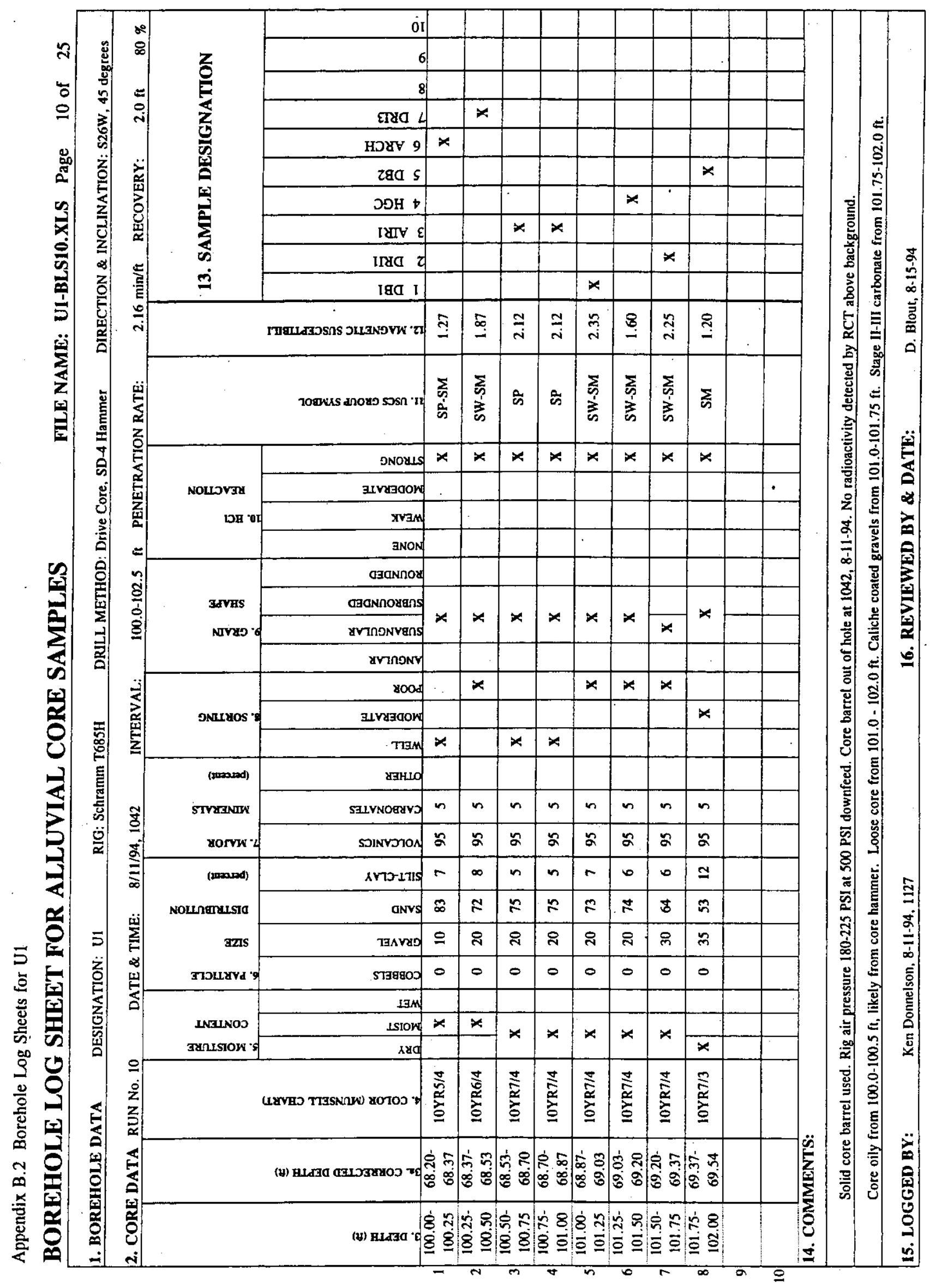




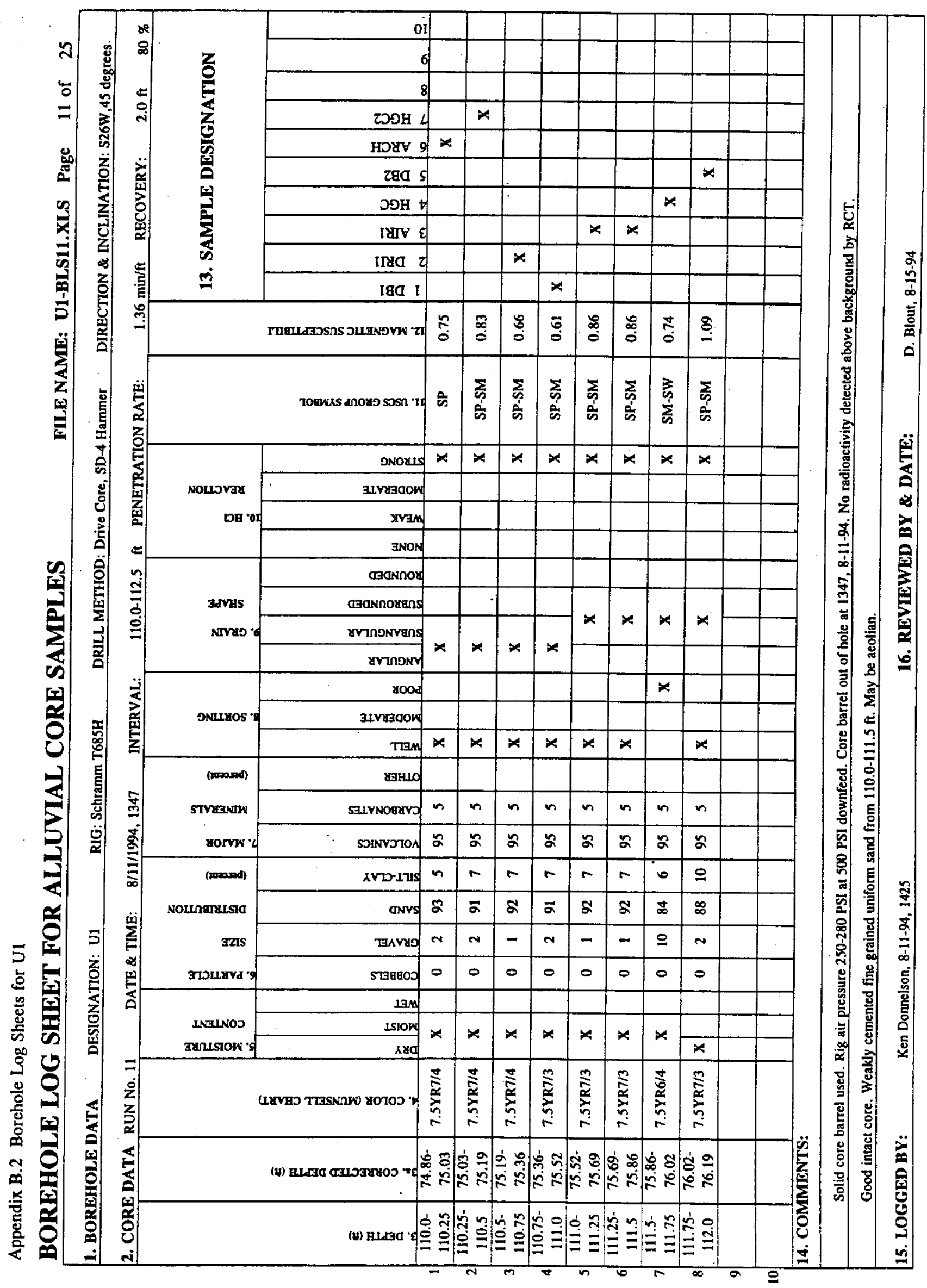




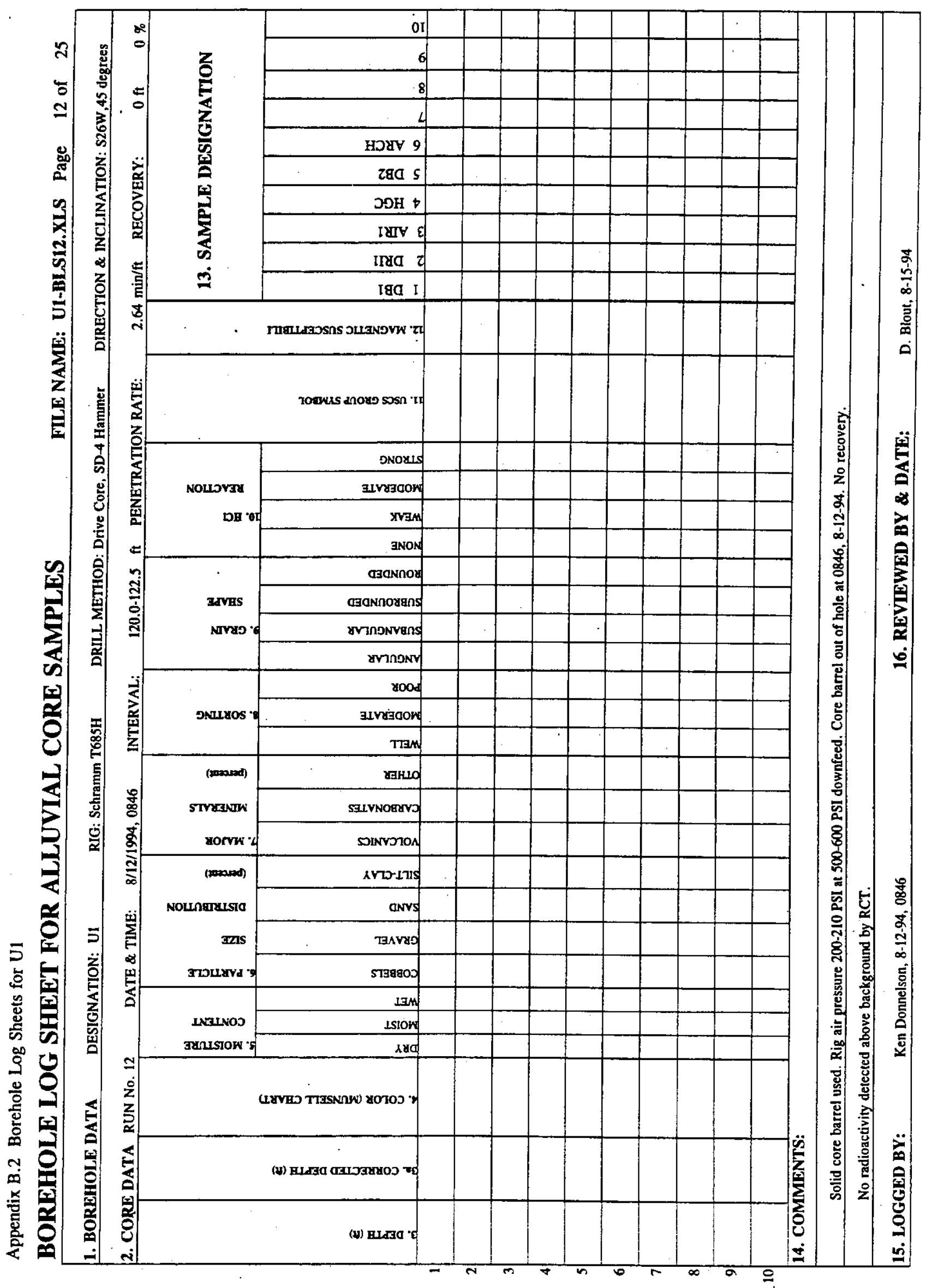




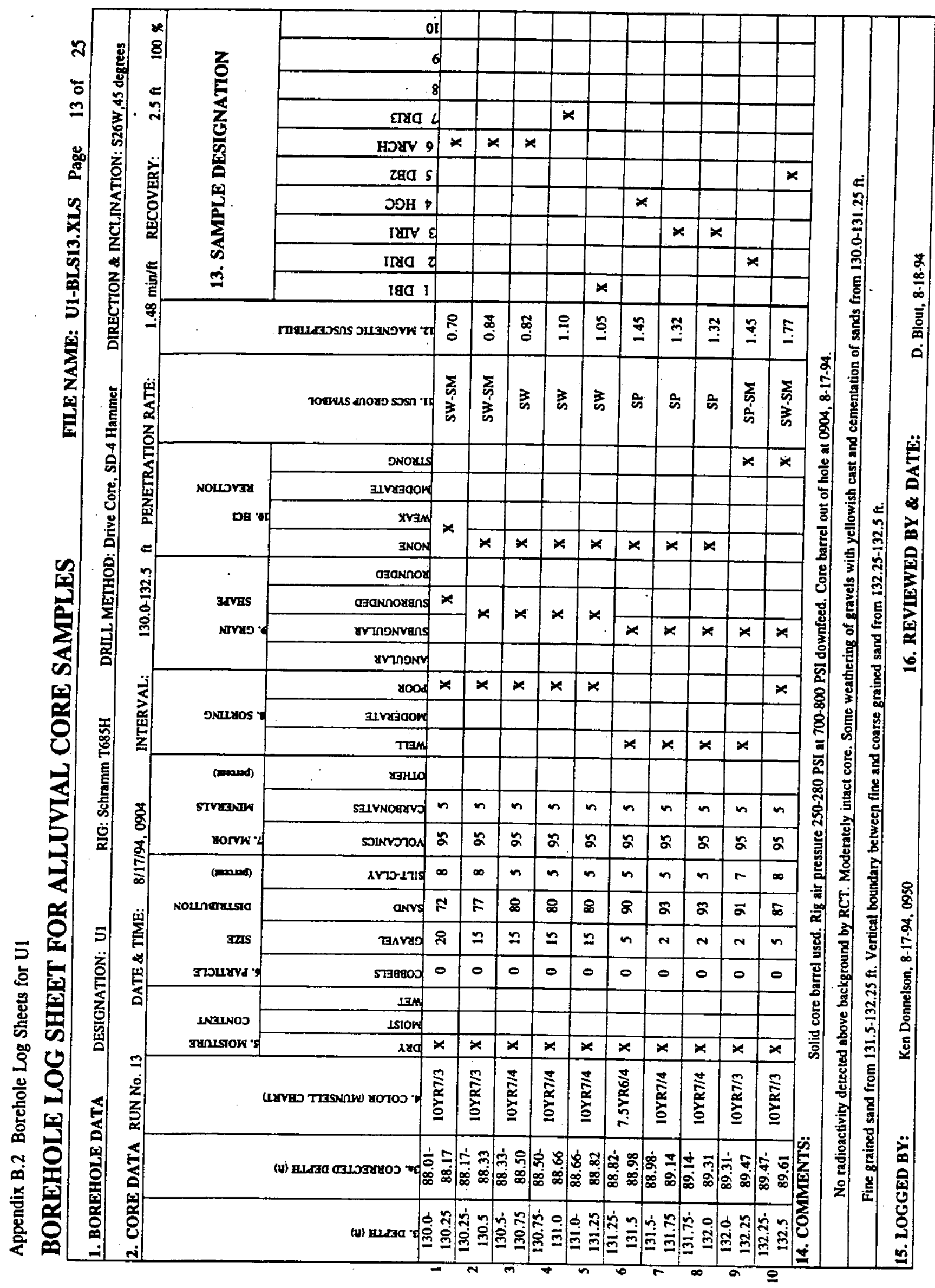




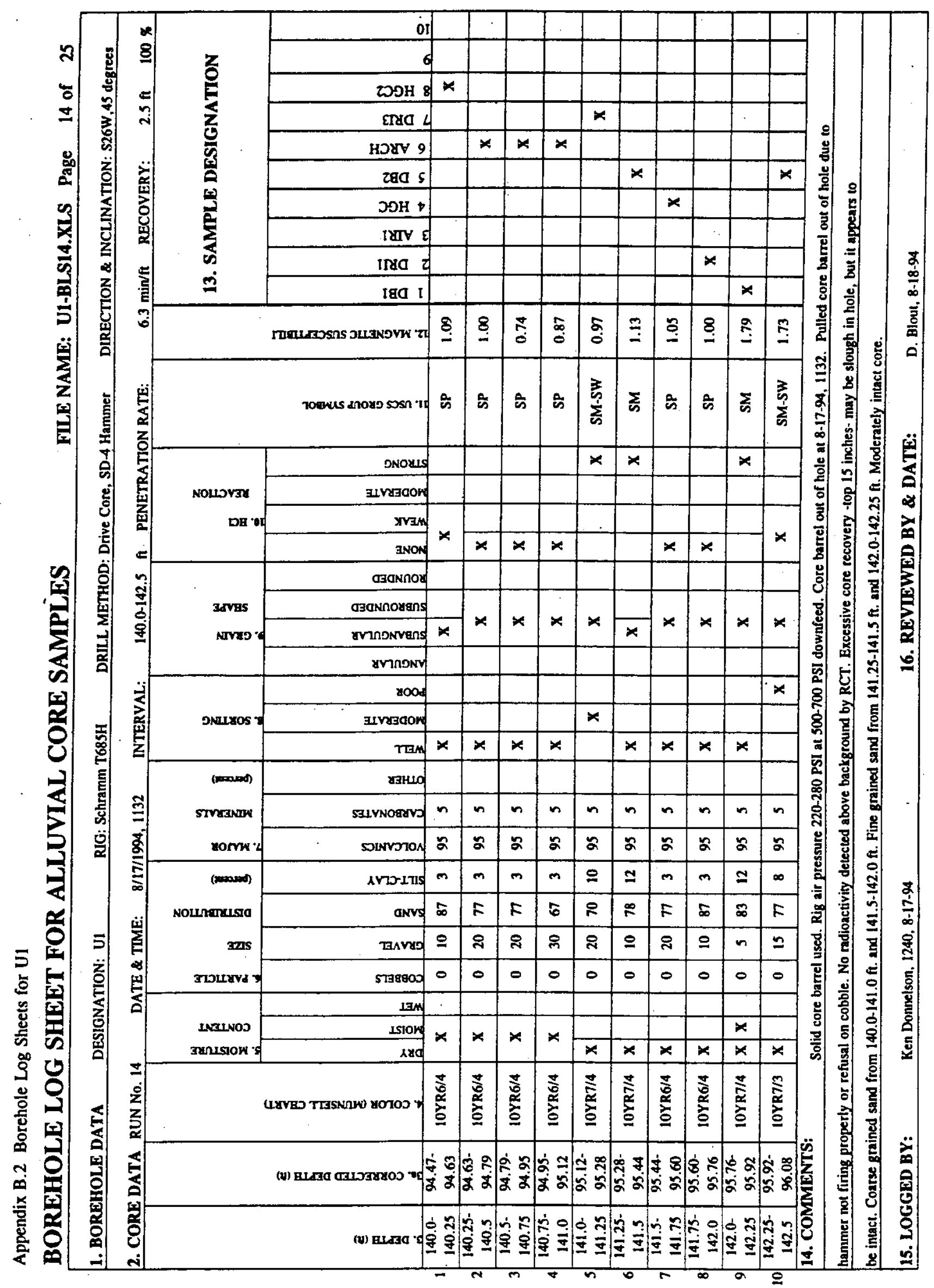




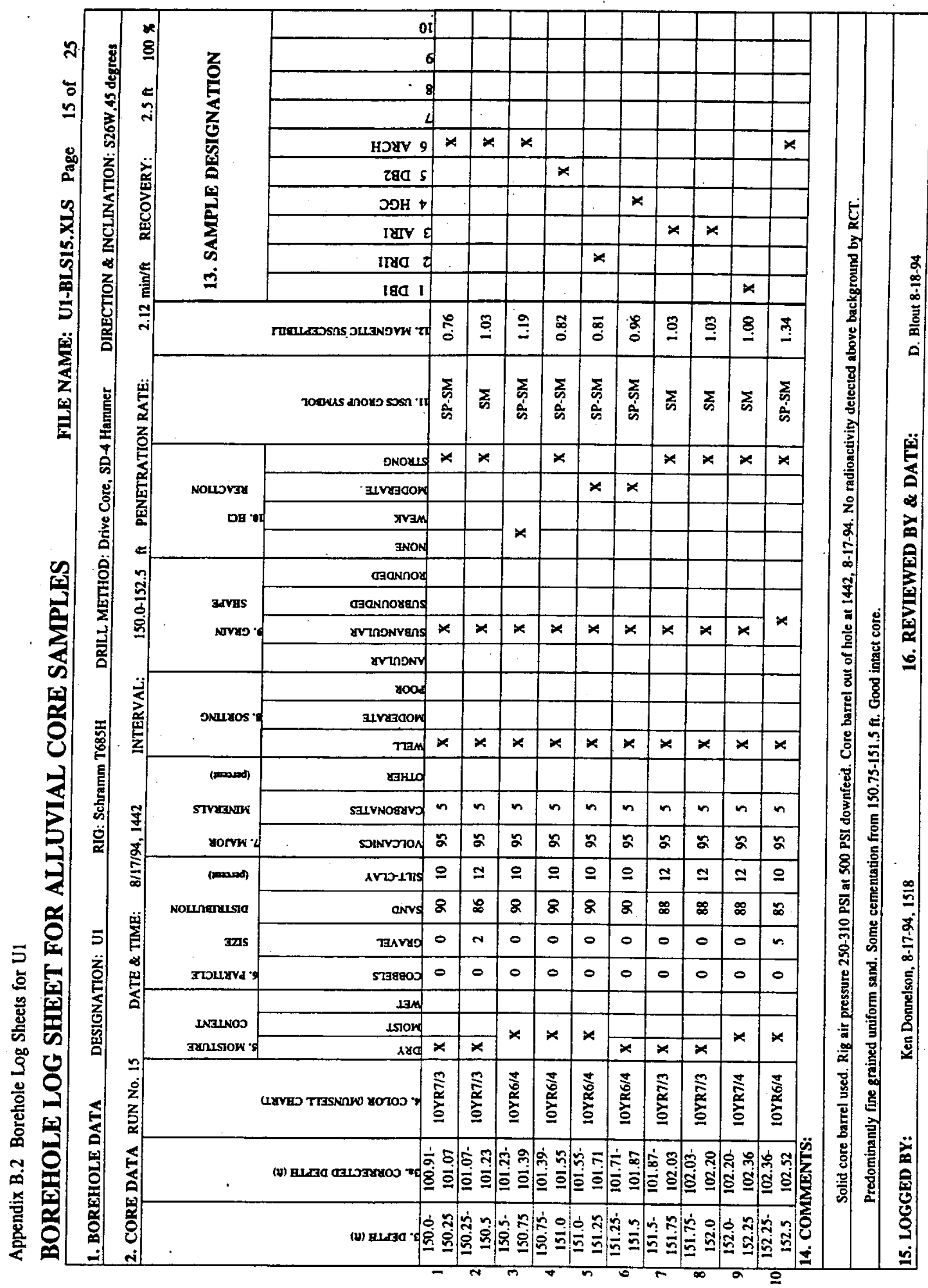




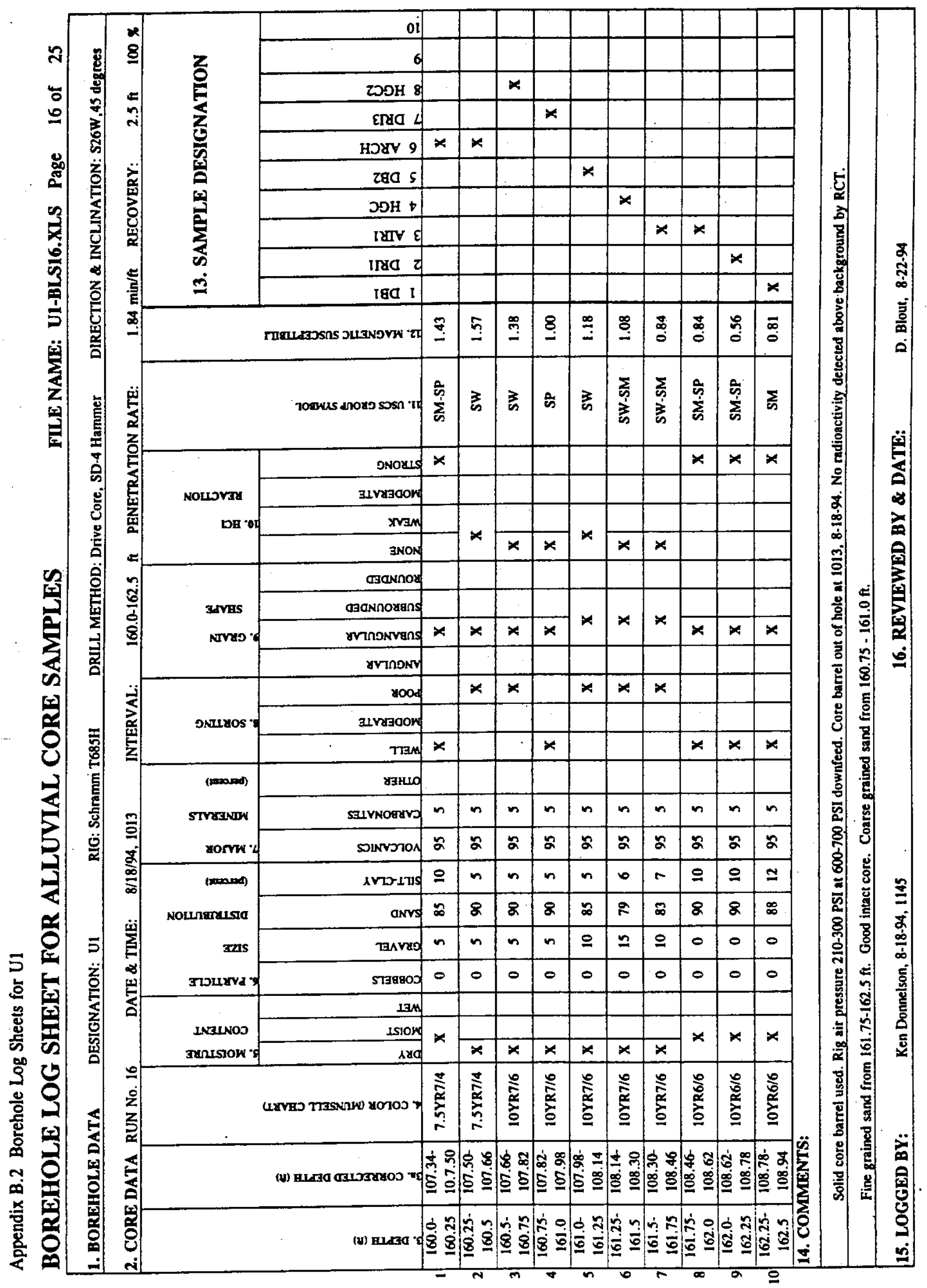




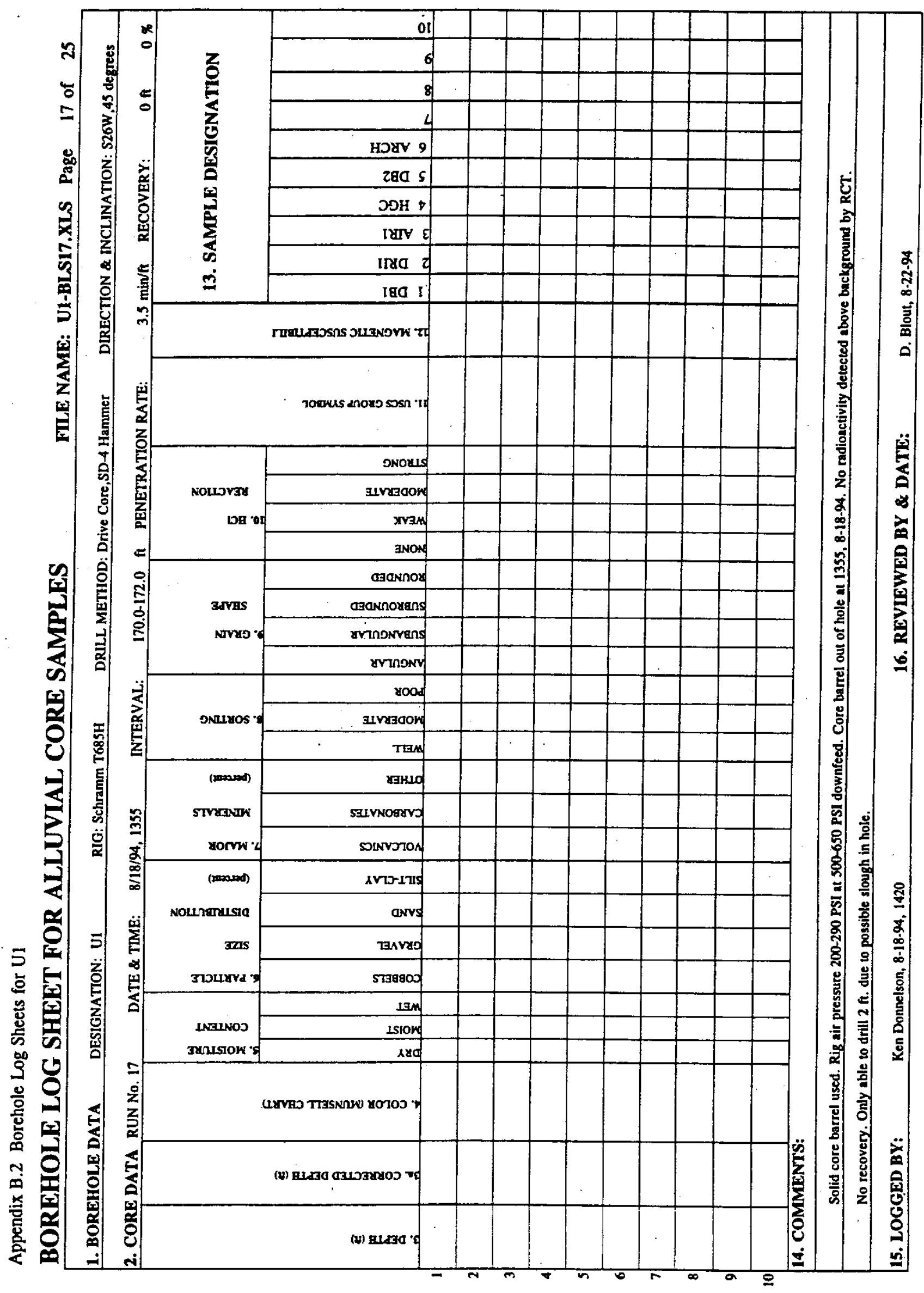




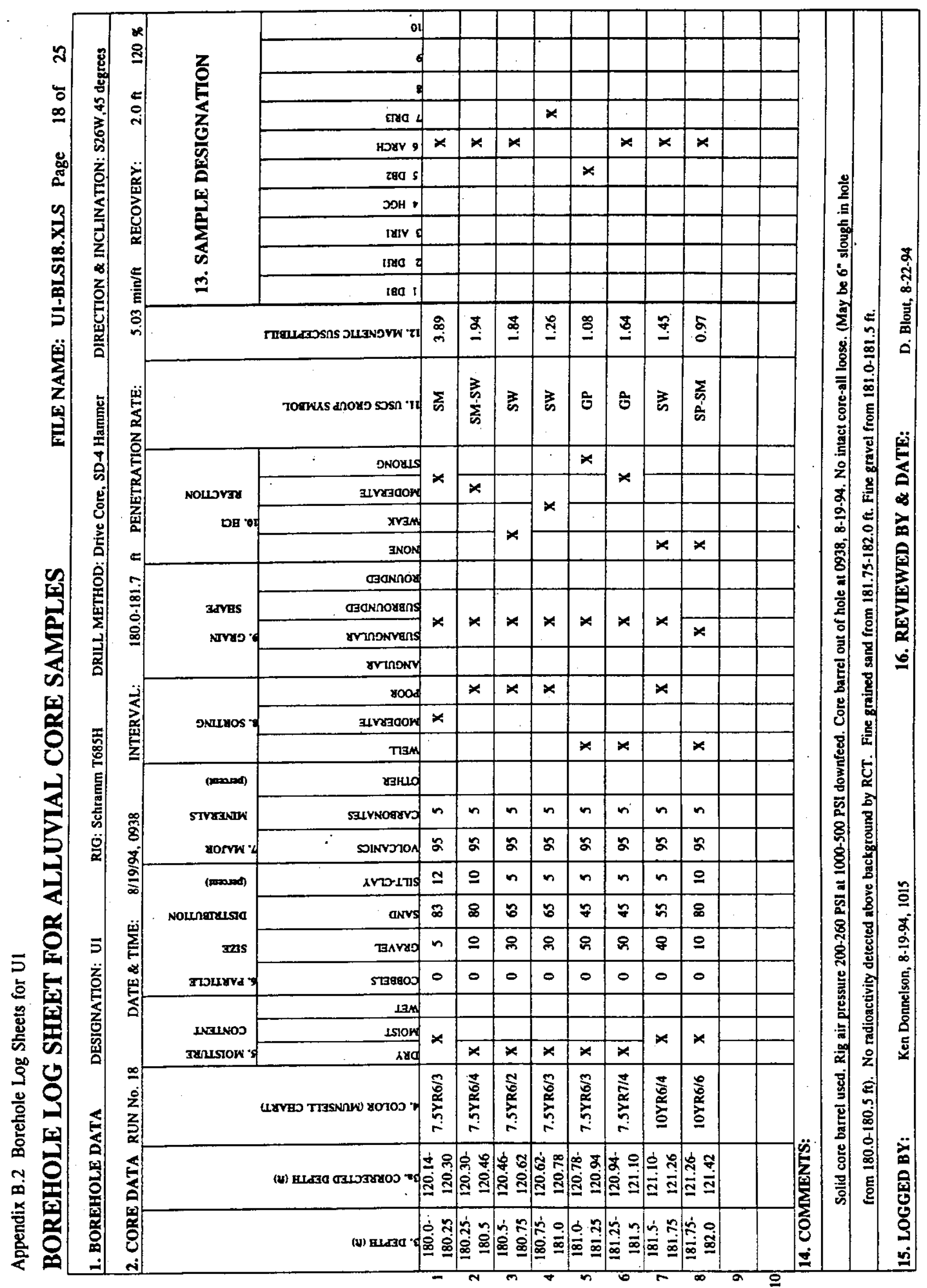




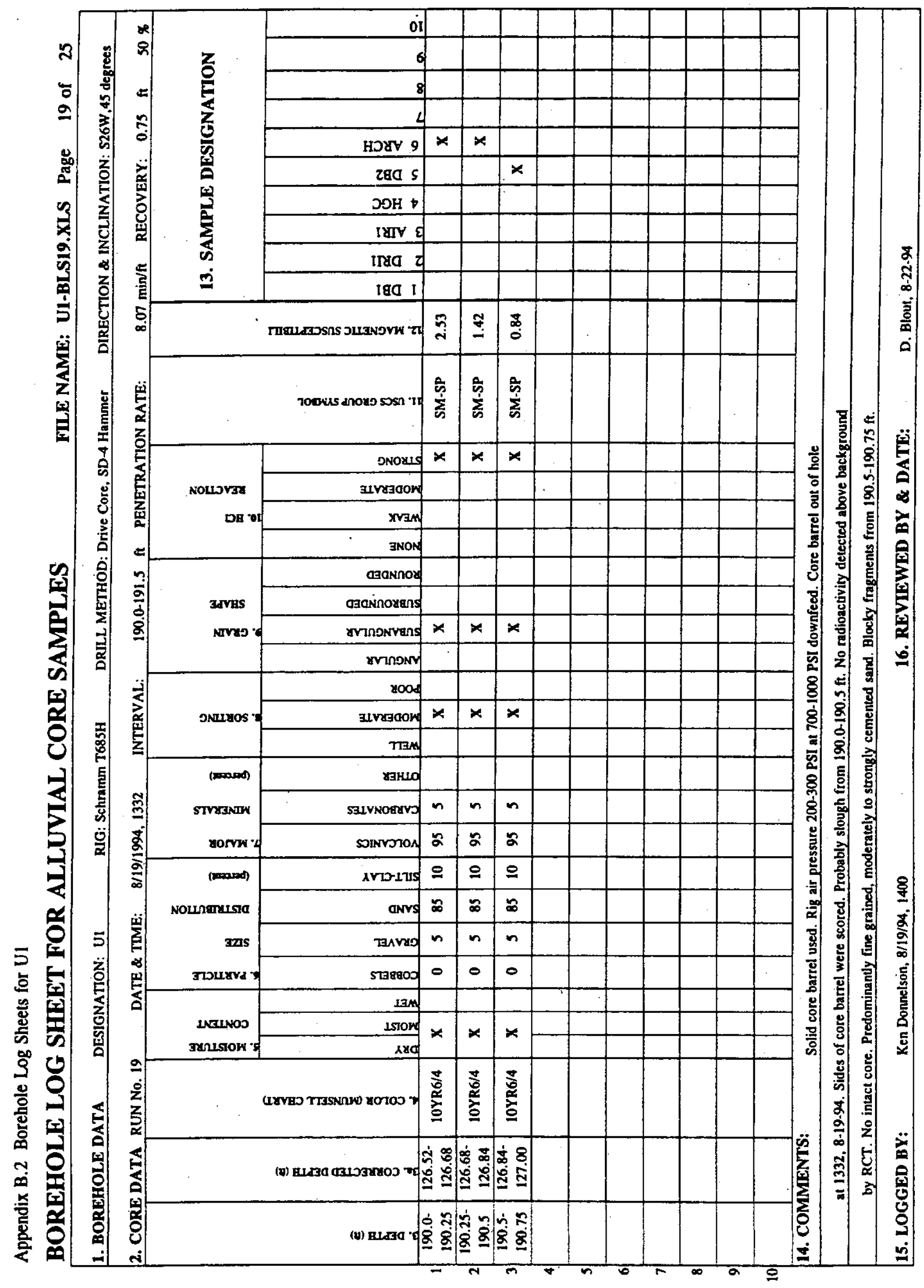




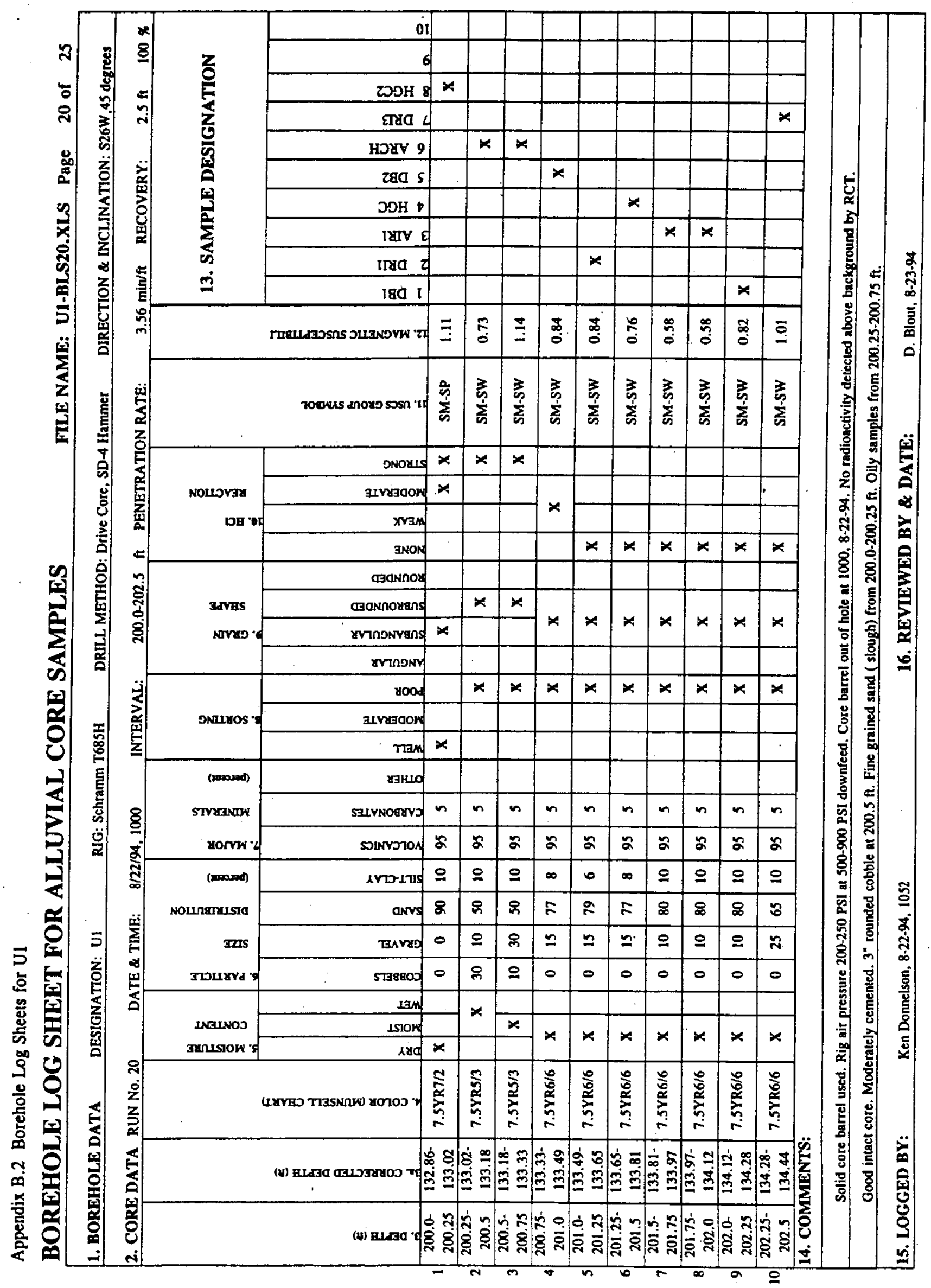




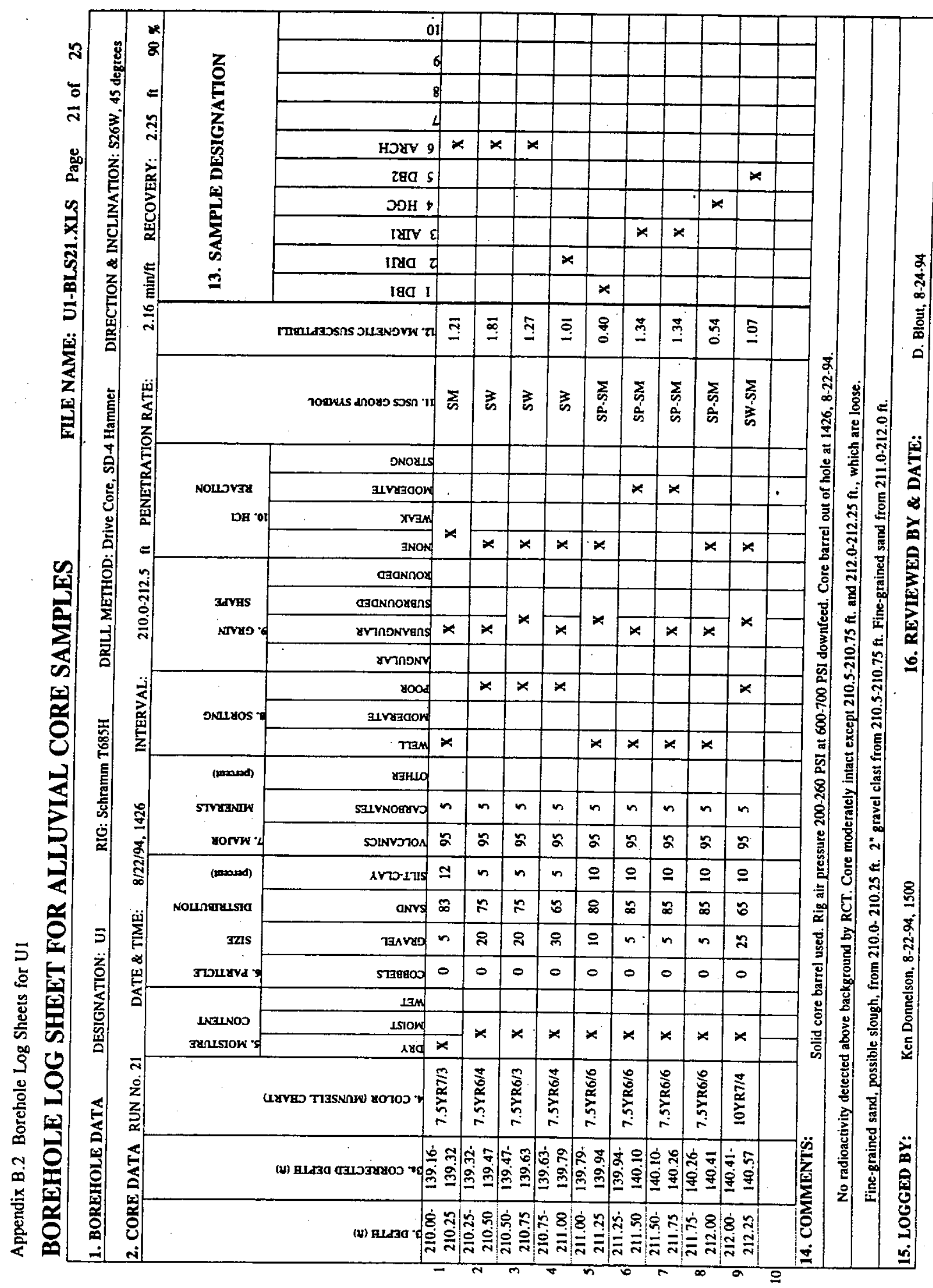




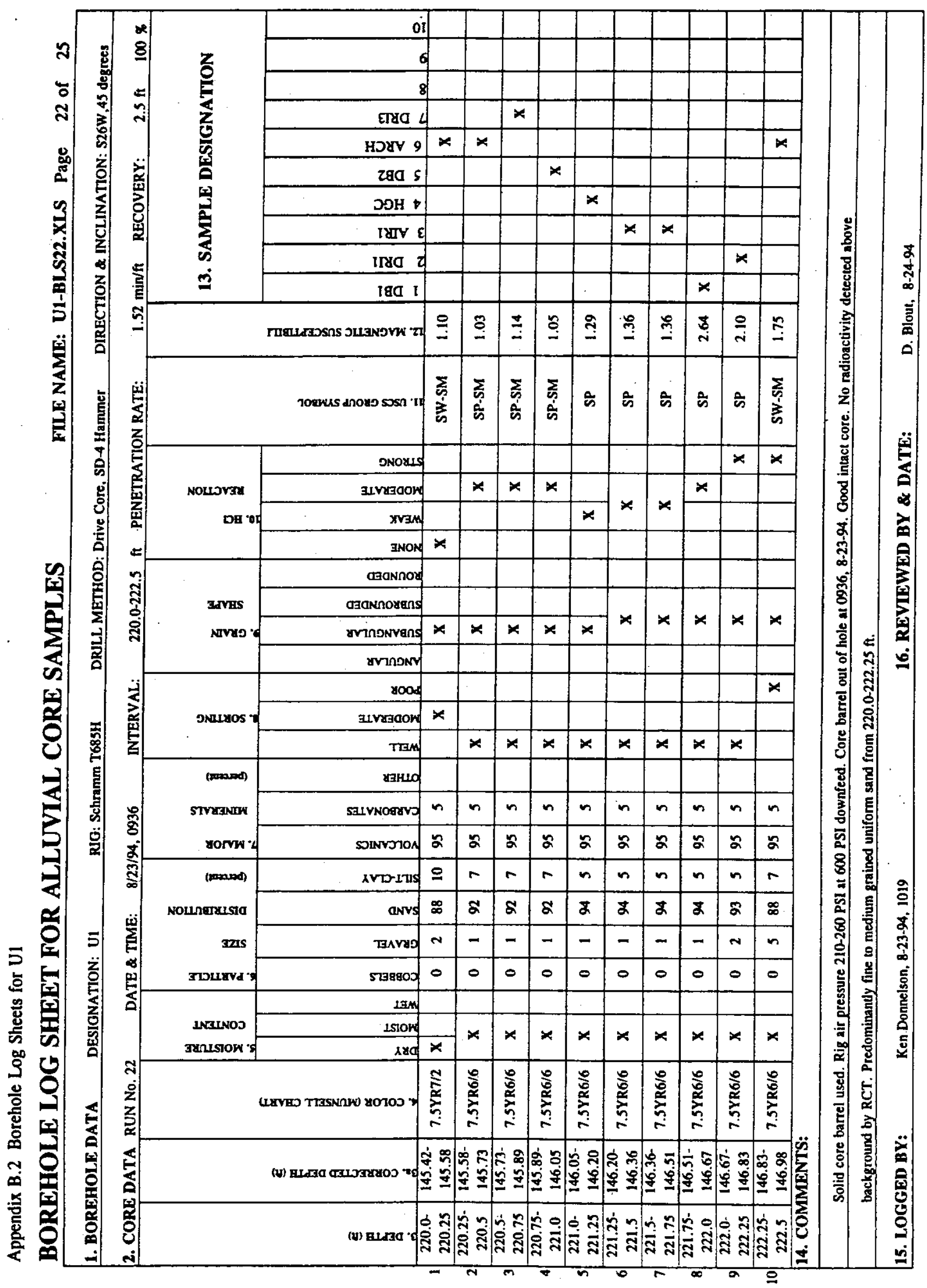




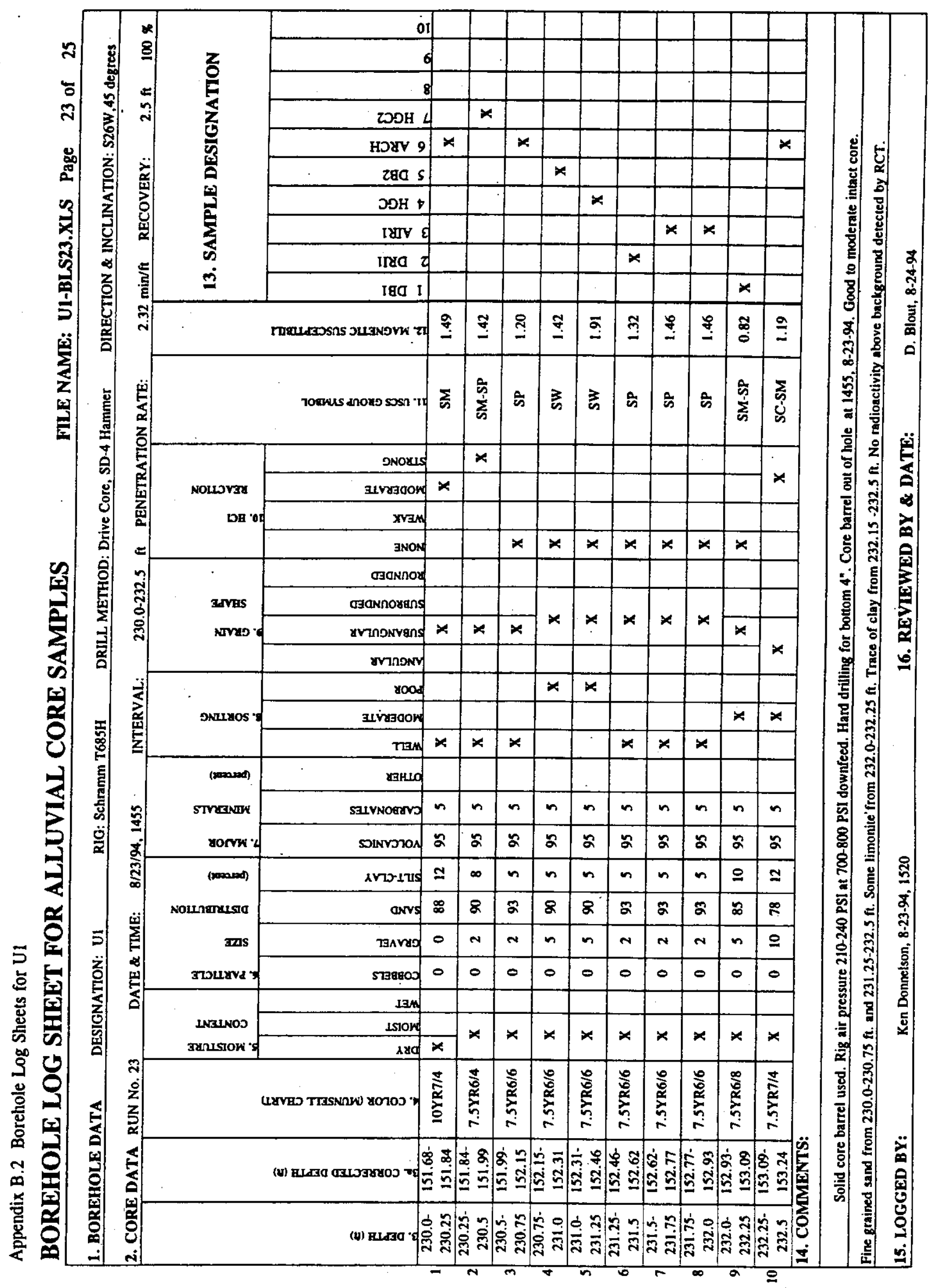




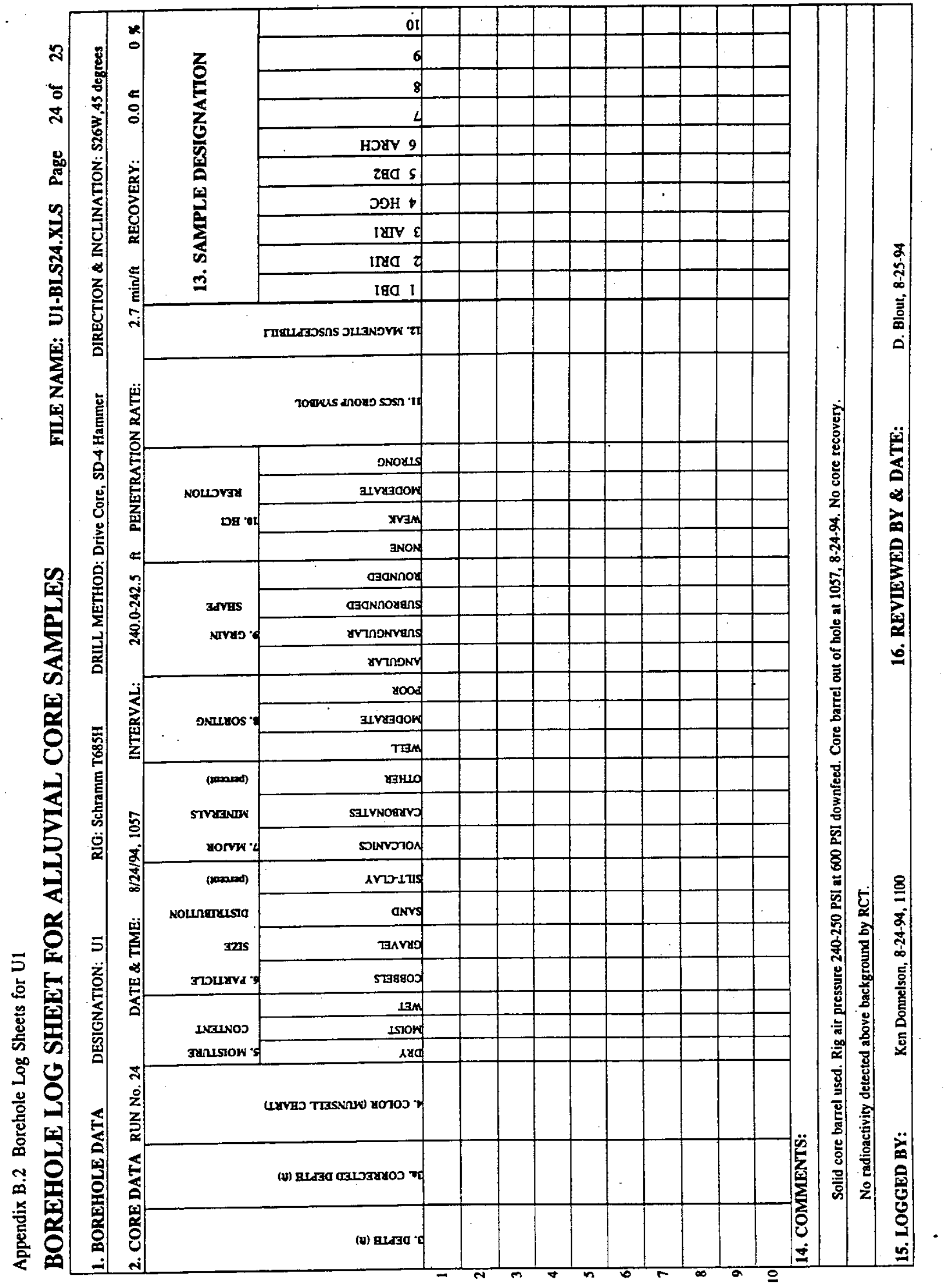




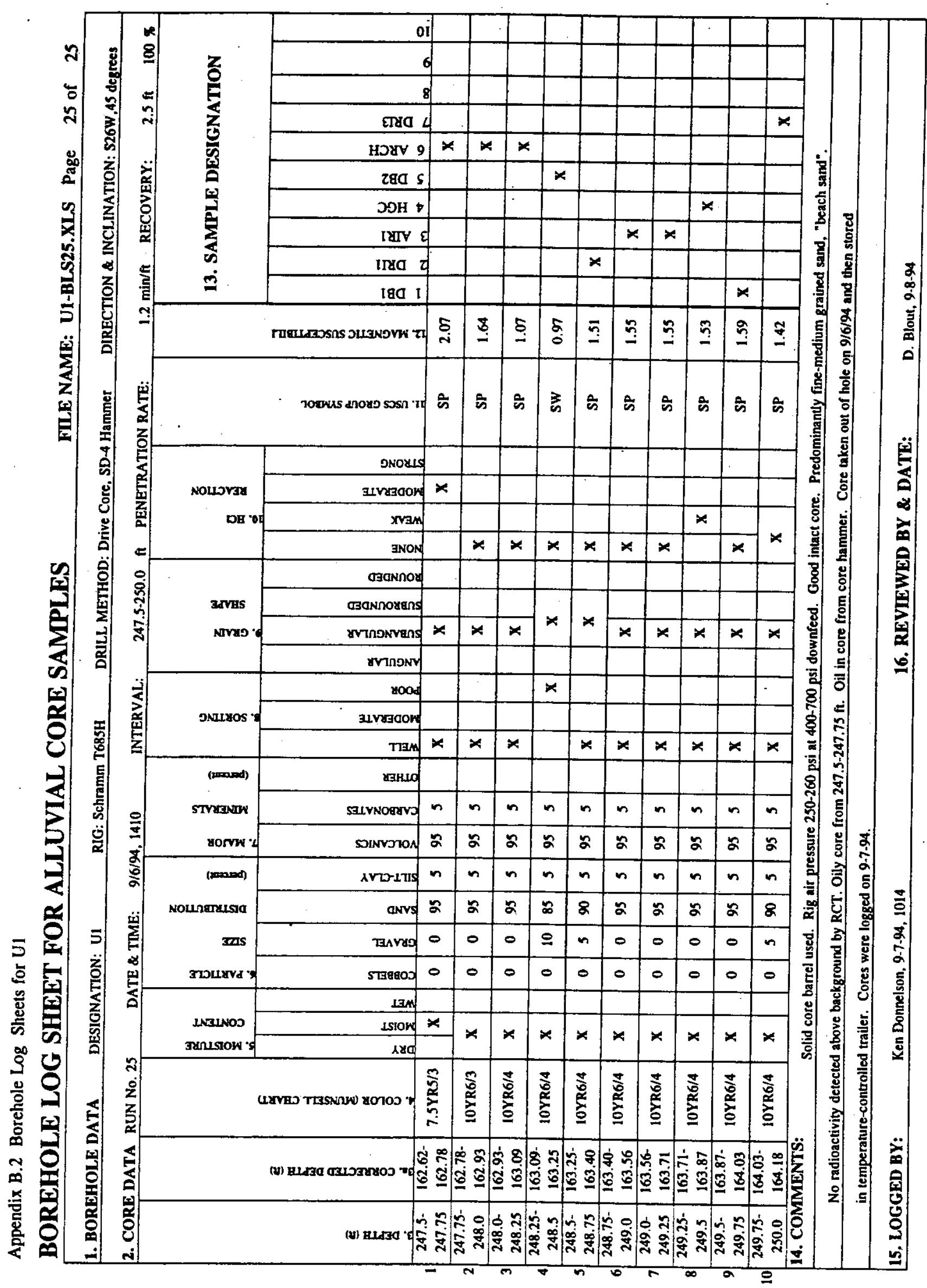




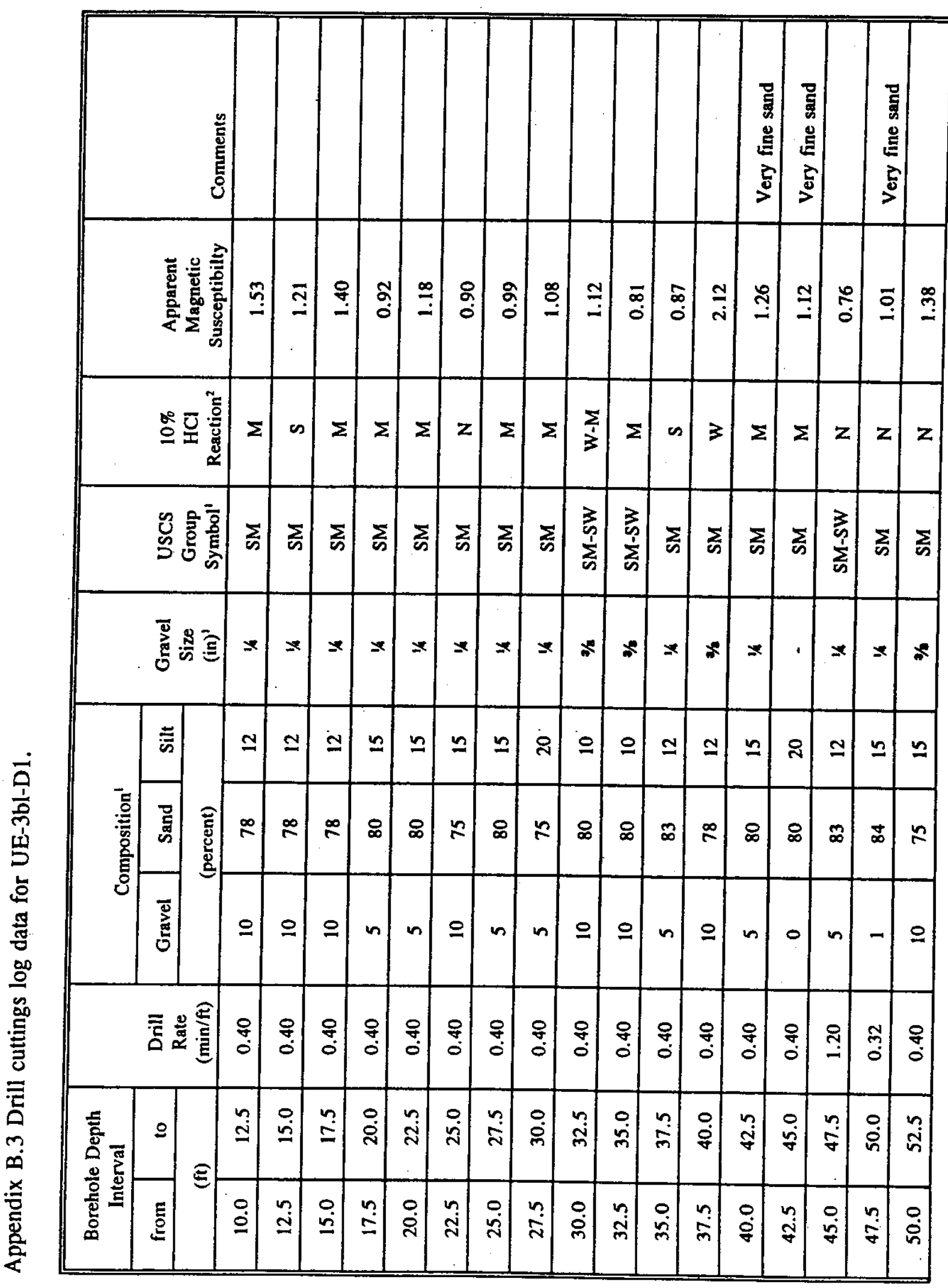




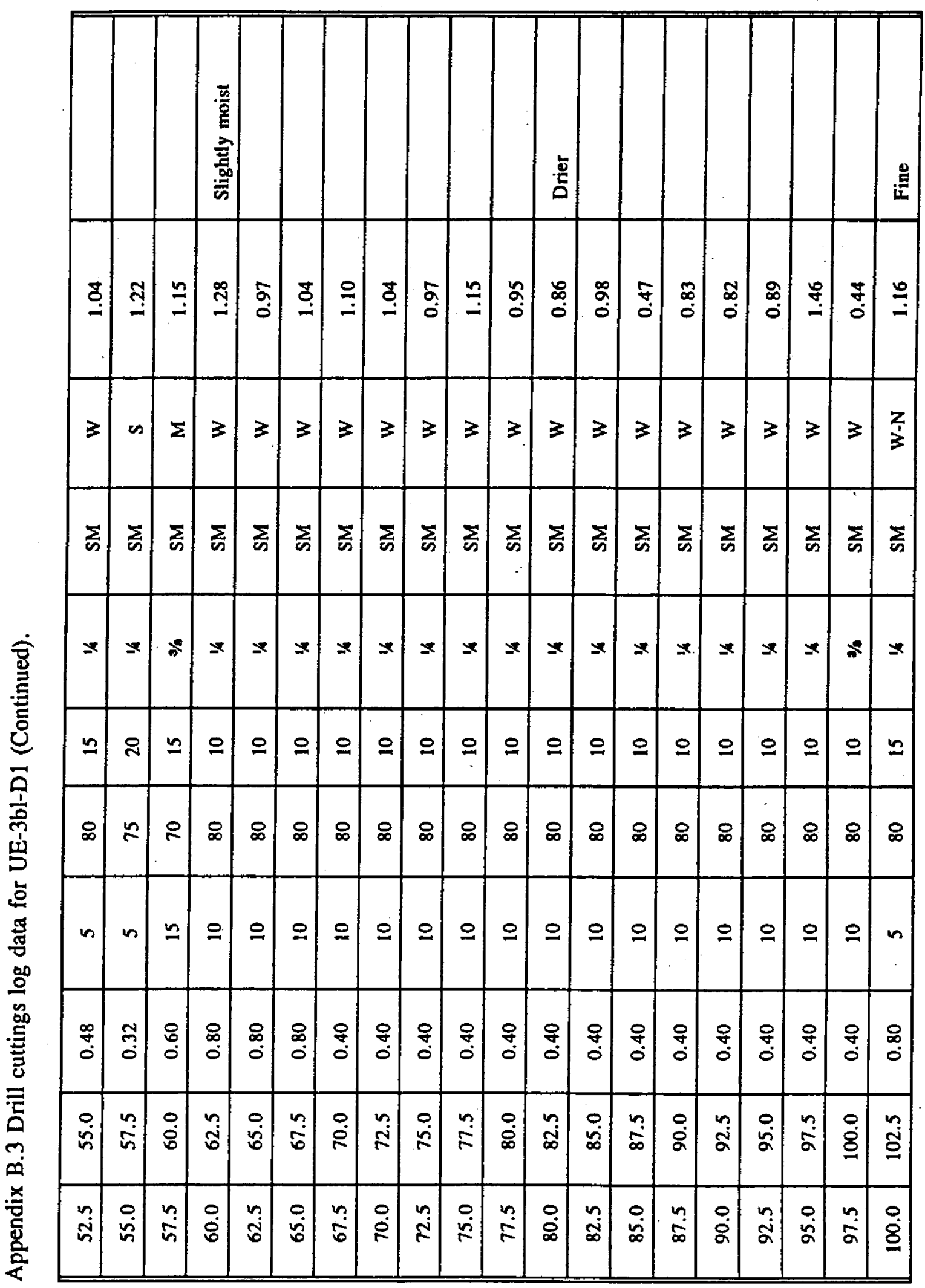




\begin{tabular}{|c|c|c|c|c|c|c|c|c|c|c|c|c|c|c|c|c|c|c|c|}
\hline 宸 & 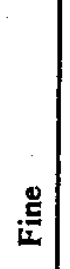 & 尊 & & & & & 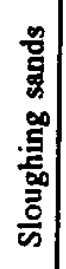 & 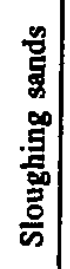 & 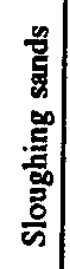 & 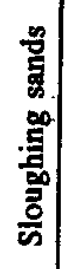 & 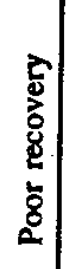 & 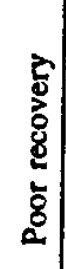 & 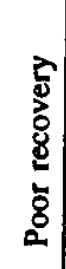 & 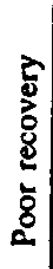 & & & & & \\
\hline $\begin{array}{l}2 \\
0 \\
0\end{array}$ & $\stackrel{-\sigma}{-}$ & $\begin{array}{c}\infty \\
\substack{\infty \\
0}\end{array}$ & 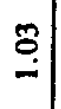 & $\begin{array}{l}\bar{a} \\
0\end{array}$ & $\stackrel{\infty}{=}$ & $\stackrel{J}{-}$ & $\stackrel{\infty}{=}$ & a & $\stackrel{8}{-}$ & $\cong$ & $\stackrel{?}{\longrightarrow}$ & $\stackrel{8}{-}$ & $\stackrel{8}{\circ}$ & 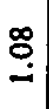 & $\begin{array}{l}\alpha \\
\sigma \\
\sigma\end{array}$ & $\stackrel{ \pm}{\Xi}$ & $\begin{array}{l}\text { ñ } \\
0\end{array}$ & 5 & $\stackrel{\circ}{\circ}$ \\
\hline $\mathbf{z}$ & $z$ & $\infty$ & $\infty$ & $\infty$ & $\infty$ & $\infty$ & $\frac{w}{2}$ & $\Sigma$ & $\frac{3}{2}$ & $\Sigma$ & $\frac{\infty}{\Sigma}$ & $\infty$ & $\infty$ & $\Sigma$ & $\Sigma$ & $\infty$ & $\sum_{i}^{\Sigma}$ & $\frac{n}{\Sigma}$ & ens \\
\hline$\sum_{k=1}$ & $\begin{array}{l}n \\
\sum_{\infty}^{n}\end{array}$ & $\sum_{n}$ & $\sum_{n}$ & $\Sigma$ & $\sum_{\infty}$ & $\sum_{\text {m }}$ & $\sum_{\substack{n \\
\hat{n}}}$ & $\begin{array}{l}\bar{n} \\
\sum_{n}^{n}\end{array}$ & 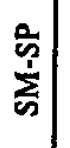 & 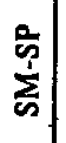 & $\sum_{\infty}$ & 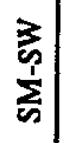 & $\sum_{\infty}$ & $\sum_{\infty}$ & $\sum_{\infty}$ & $\sum_{\infty}$ & 紊 & 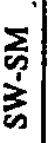 & $\sum$ \\
\hline
\end{tabular}

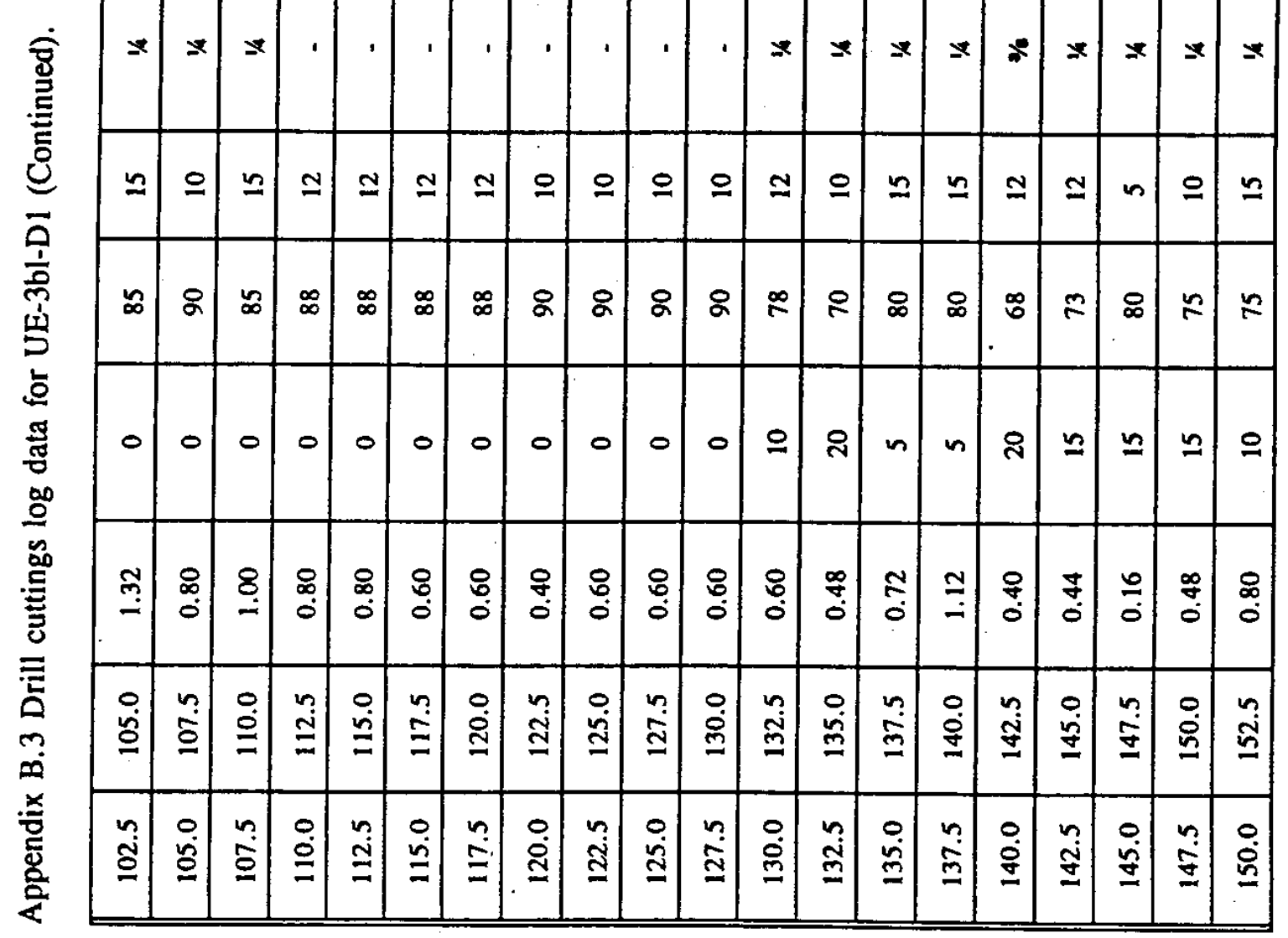




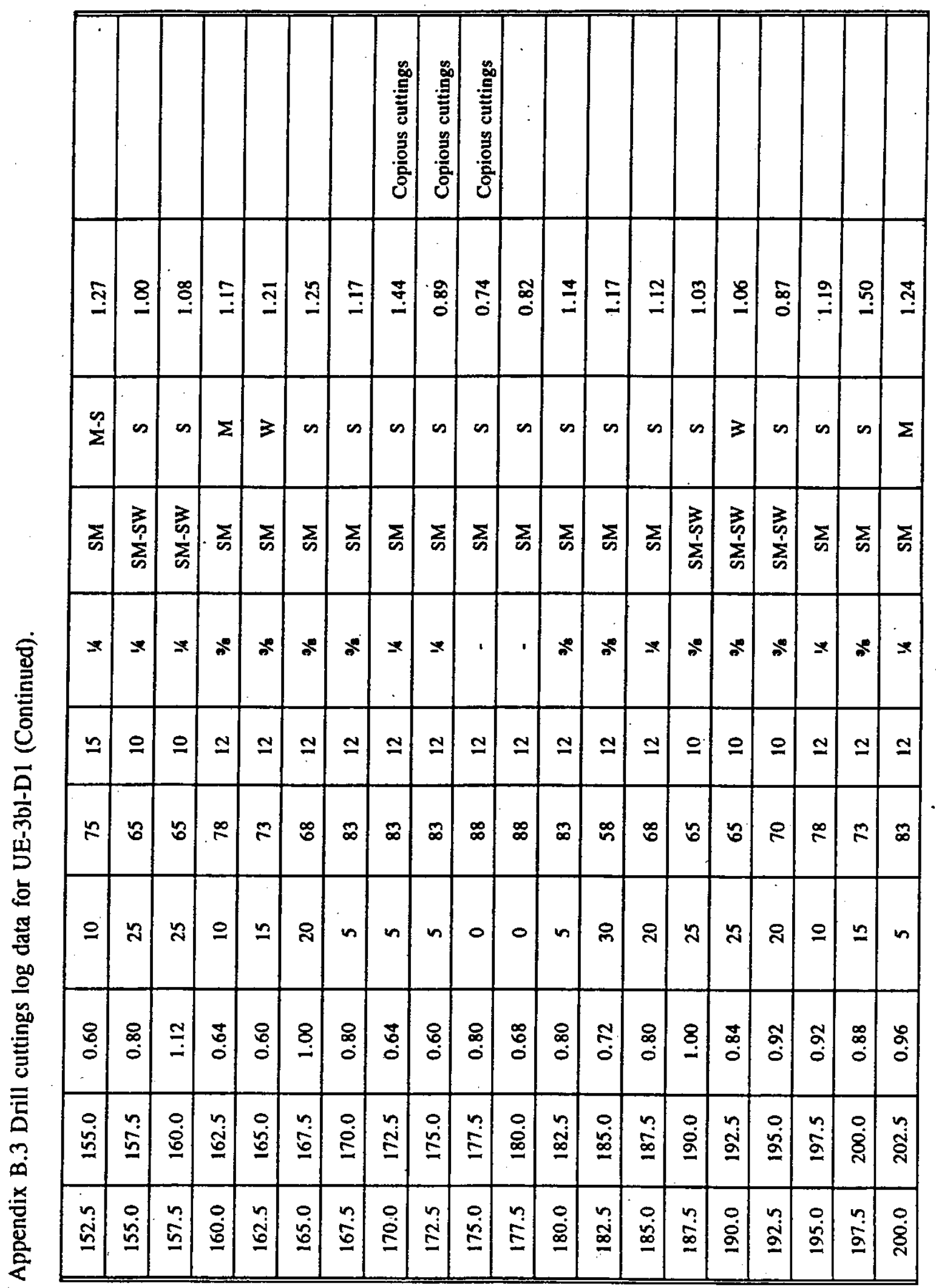




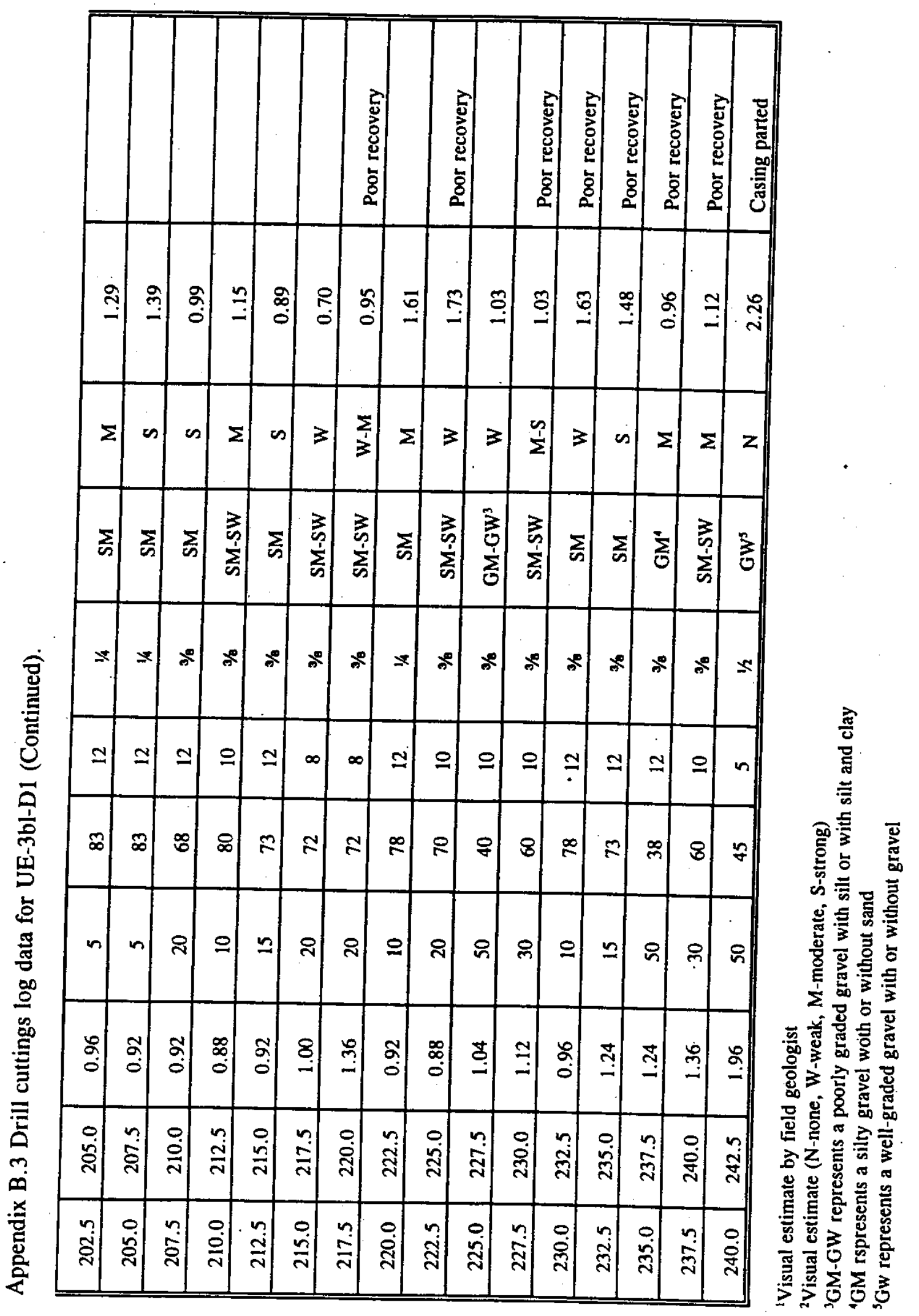




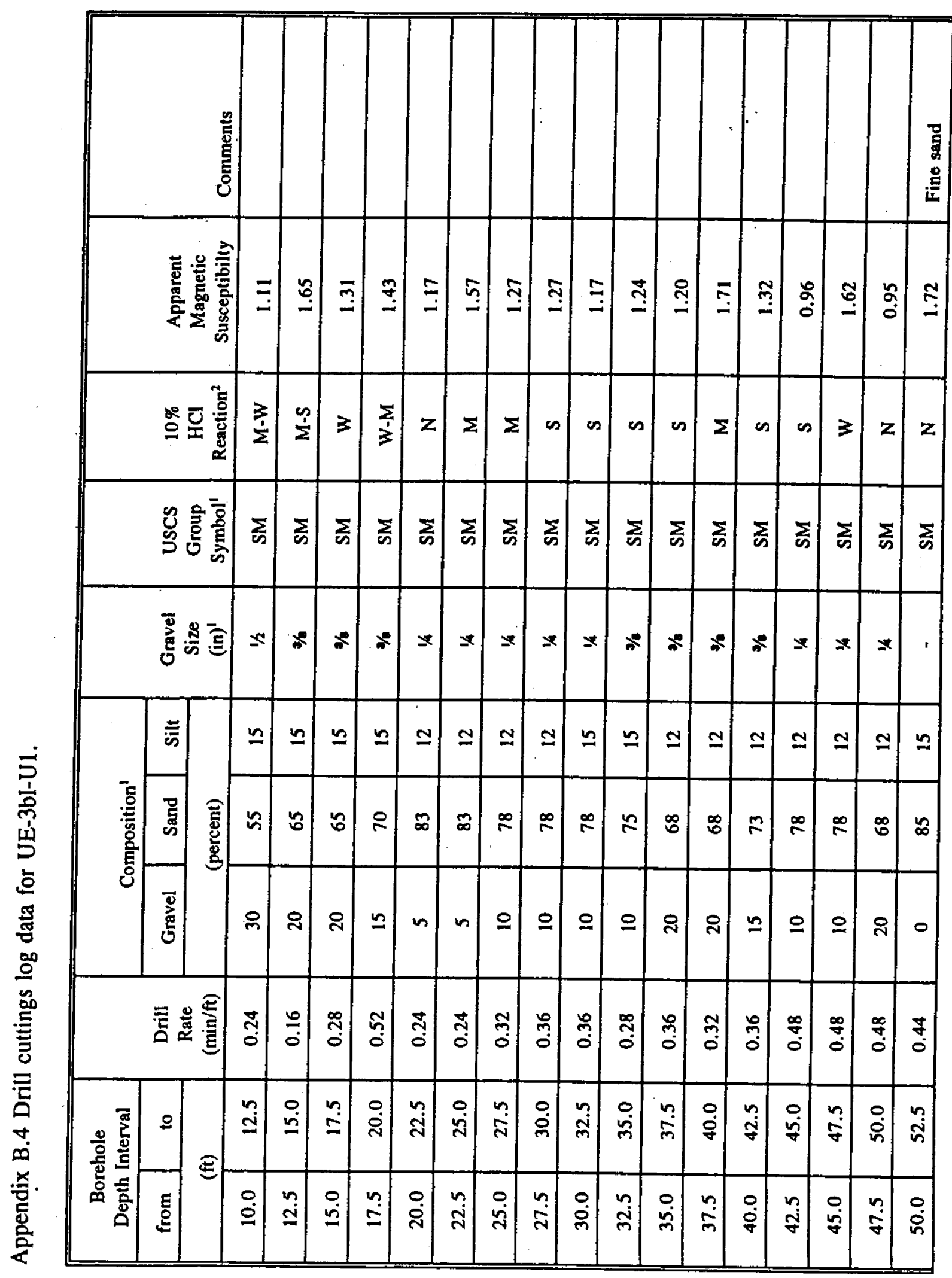




\begin{tabular}{|c|c|c|c|c|c|c|c|c|c|c|c|c|c|c|c|c|c|c|c|}
\hline 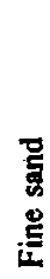 & & & & & & & & & & & 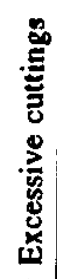 & & & & & 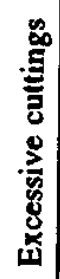 & 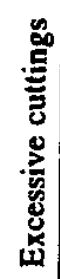 & 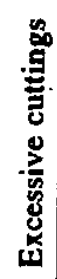 & \\
\hline$\stackrel{\infty}{\stackrel{\circ}{-~}}$ & $\stackrel{\infty}{\stackrel{0}{0}}$ & $\stackrel{2}{2}$ & $\begin{array}{l}\infty \\
0 \\
0\end{array}$ & 8 & 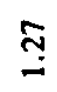 & $\stackrel{I}{\Xi}$ & $\stackrel{5}{i}$ & $\stackrel{\infty}{0}$ & $\bar{a}$ & $\frac{N}{\circ}$ & $\begin{array}{l}\mathbb{\infty} \\
0 \\
0\end{array}$ & $\frac{1}{0}$ & $\stackrel{\alpha}{0}$ & s. & $\hat{a}$ & ई̊ & $\frac{F}{\circ}$ & 5 & $\stackrel{\infty}{\dddot{m}}$ \\
\hline$z$ & $\infty$ & $\frac{n}{\sum}$ & $\Sigma$ & $\Sigma$ & $n$ & $\infty$ & $\Sigma$ & n & $\geqslant$ & os & $\infty$ & $n$ & $\infty$ & ns & $\Sigma$ & 3 & $\infty$ & is & in \\
\hline$\sum_{\text {隹 }}$ & $\sum_{\infty}$ & $\frac{3}{\sum_{n}^{2}}$ & $\sum_{\infty}^{3}$ & $\sum_{\text {ஸे }}$ & $\sum_{\zeta}$ & $\sum_{\infty}$ & ¿ & $\sum_{\infty}$ & $\sum_{5}^{3}$ & $\sum_{n}$ & $\sum_{\infty}^{\Sigma}$ & $\sum_{\infty}$ & $\sum_{n}$ & $\frac{0}{2}$ & $\sum_{\infty}$ & $\sum_{\infty}$ & $\sum_{n}$ & $\sum_{\infty}$ & $\sum_{5}$ \\
\hline
\end{tabular}

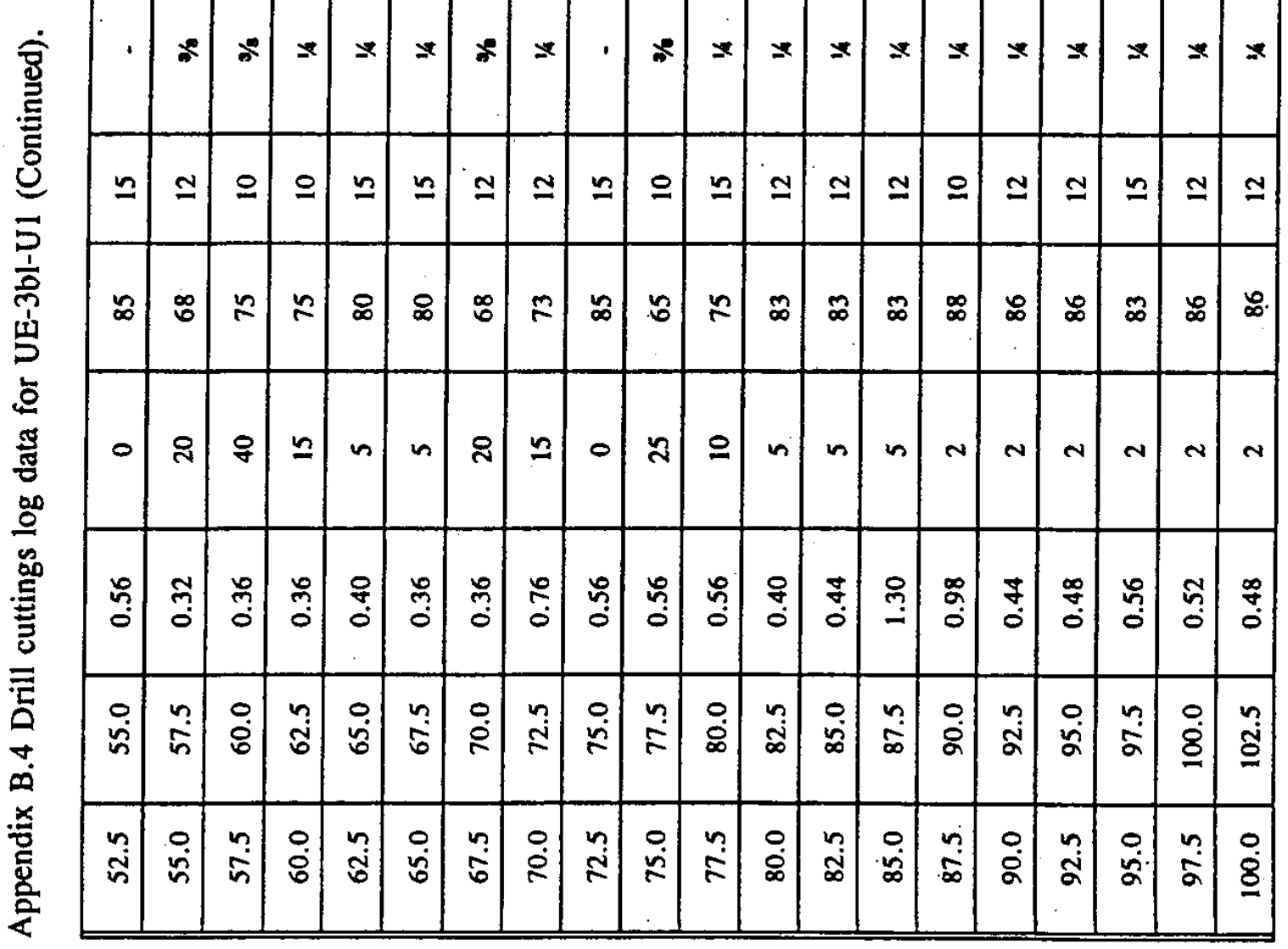




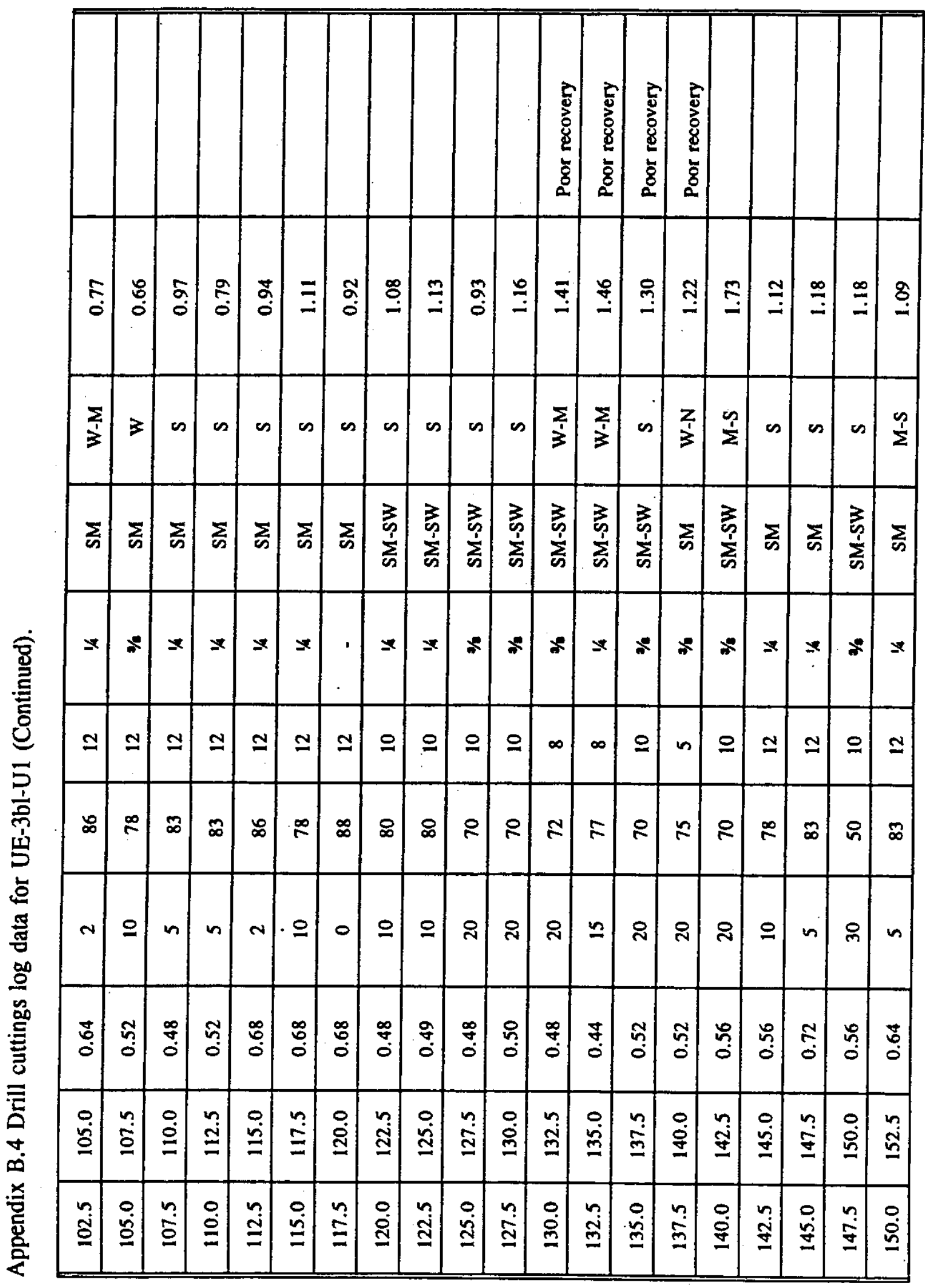




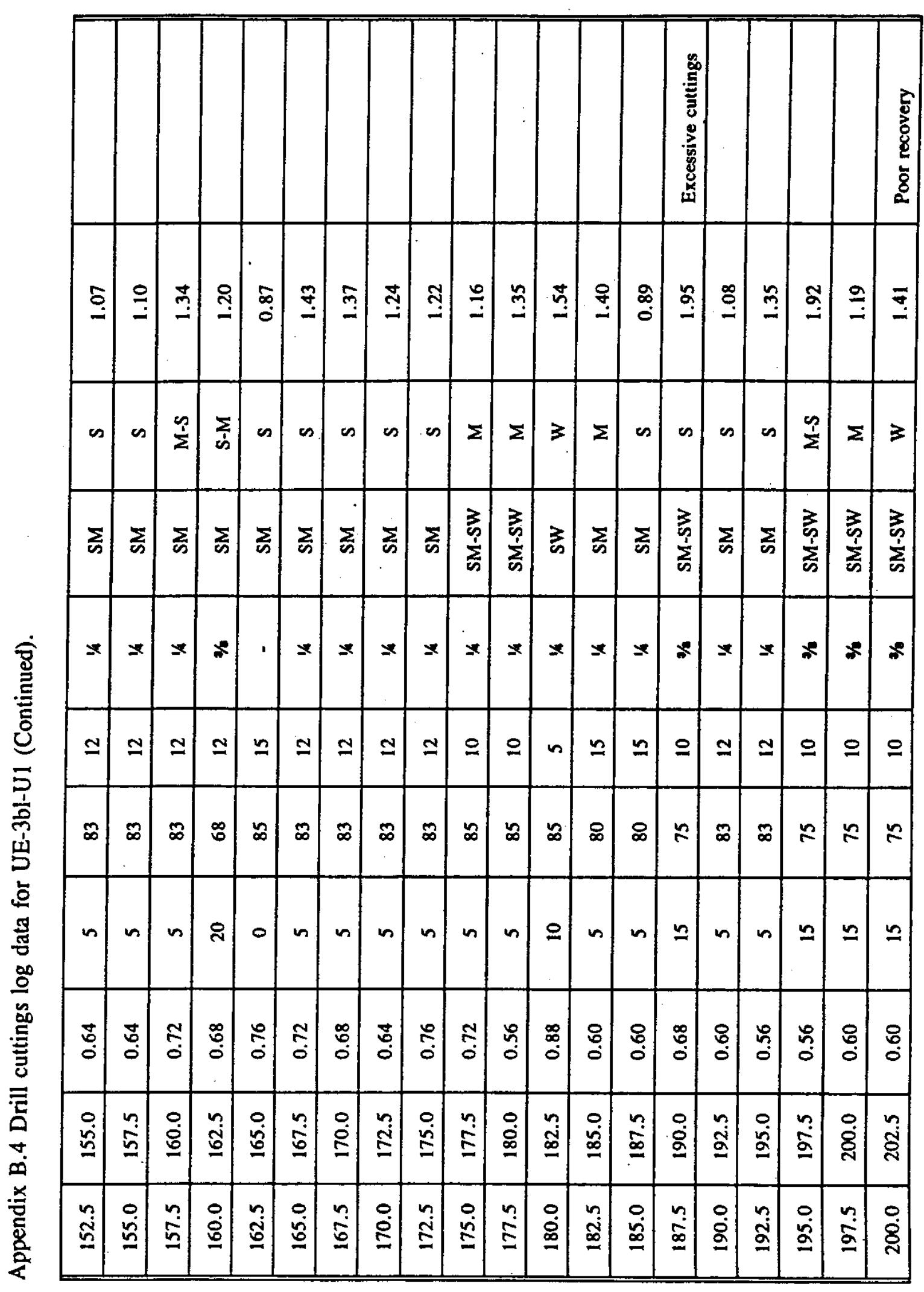




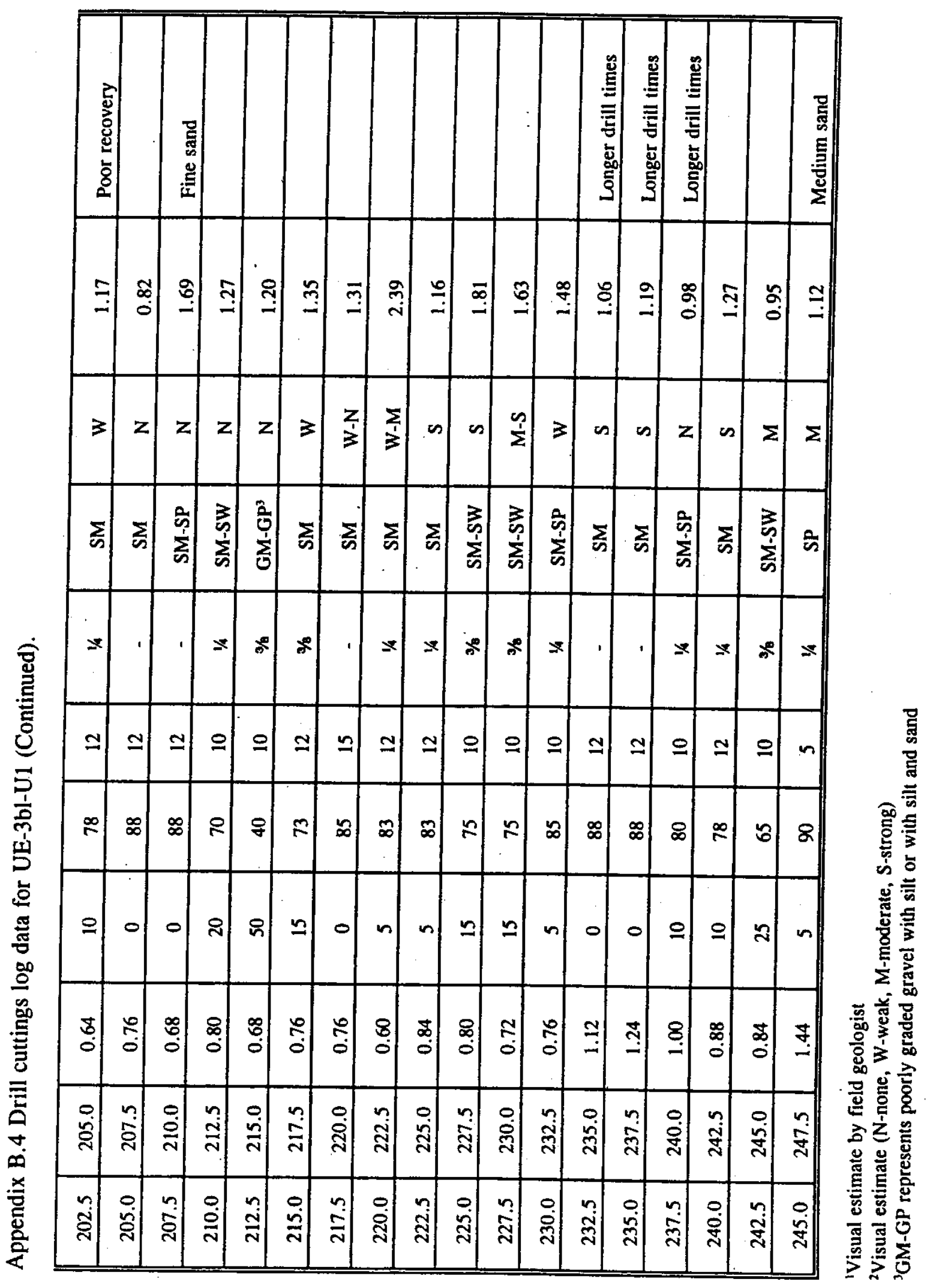




\title{
U3ax/bl Exploratory Boreholes
}

\author{
Appendix C
}

\section{Laboratory Testing Data of Geologic Samples}




\section{U3ax/bl Exploratory Boreholes}

\section{Appendix C \\ Laboratory Testing Data of Geologic Samples}

C.1 Results of Laboratory Tests for Hydrogeologic Properties for Core Samples from UE-3bl-D1

C.2 Results of Laboratory Tests for Physical and Pneumatic Properties for Core Samples from UE-3bl-D1

C.3 Results of Laboratory Tests for Chemical Properties and Environmental Tracer Data for Core Samples from UE-3bl-D1

C.4 Results of Gravimetric Water Content Measurements for Drill Cuttings Samples from UE-3bl-D1

C.5 Results of Unenriched Tritium Analysis for Drill Cuttings and Core Samples from UE-3bl-D1

C.6 Results of Laboratory Tests for Hydrogeologic Properties for Core Samples from UE-3bl-U1

C.7 Results of Laboratory Tests for Physical and Pneumatic Properties for Core Samples from UE-3bl-U1

C.8 Results of Laboratory Tests for Chemical Properties and Environmental Tracer Data for Core Samples from UE-3bl-U1

C.9 Results of Gravimetric Water Content Measurements for Drill Cuttings Samples from UE-3bl-U1

C.10 Moisture Retention Data for Core Samples from UE-3bl-D1

C.11 Moisture Retention Data for Core Samples from UE-3bl-U1

C.12 Parameters Required to Calculate Unsaturated Hydraulic Conductivities for Core Samples from the U3ax/bl Exploratory Boreholes

C.13 Results of Unenriched Tritium Analysis for Core Samples from UE-3bl-U1 


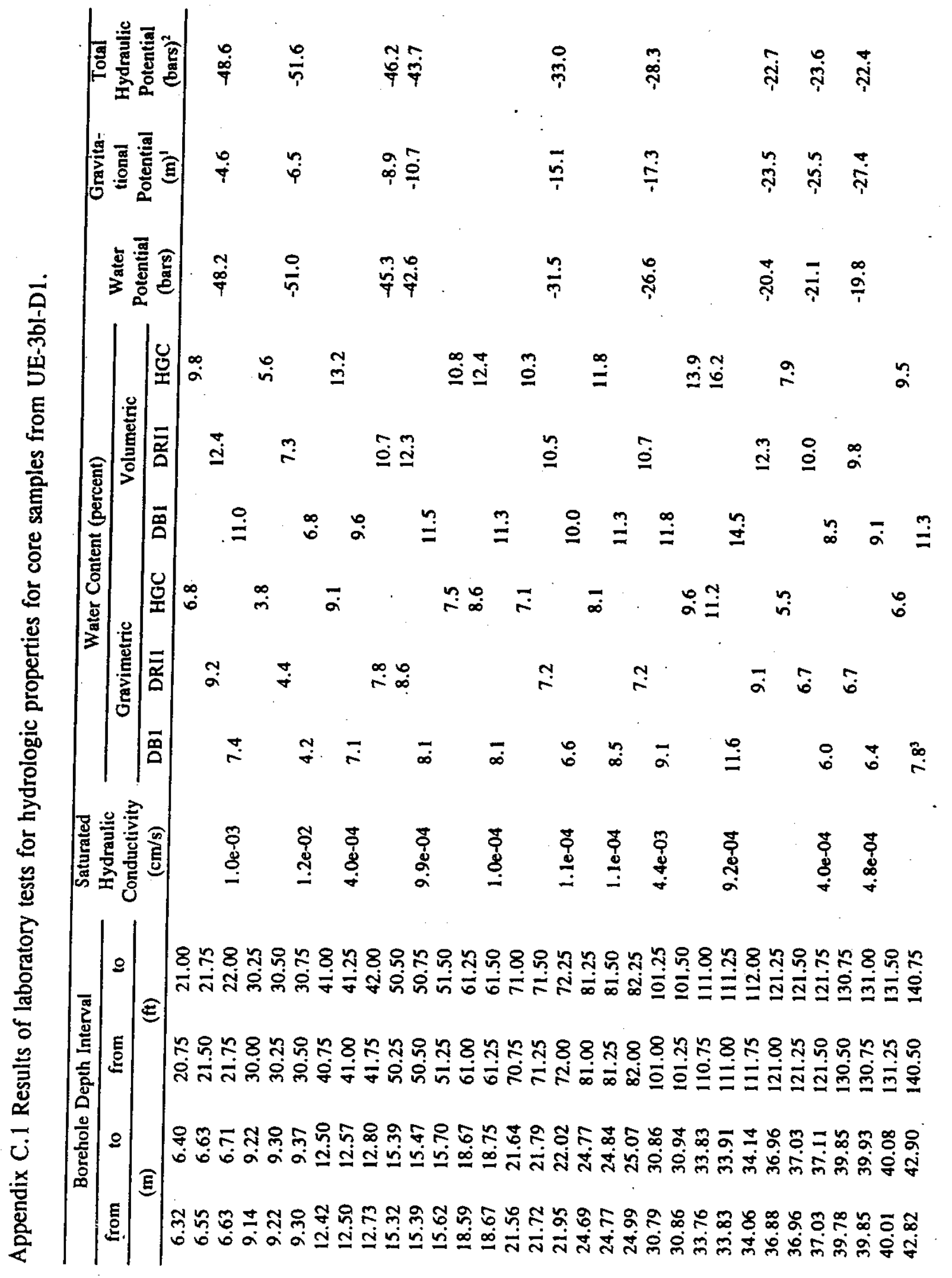




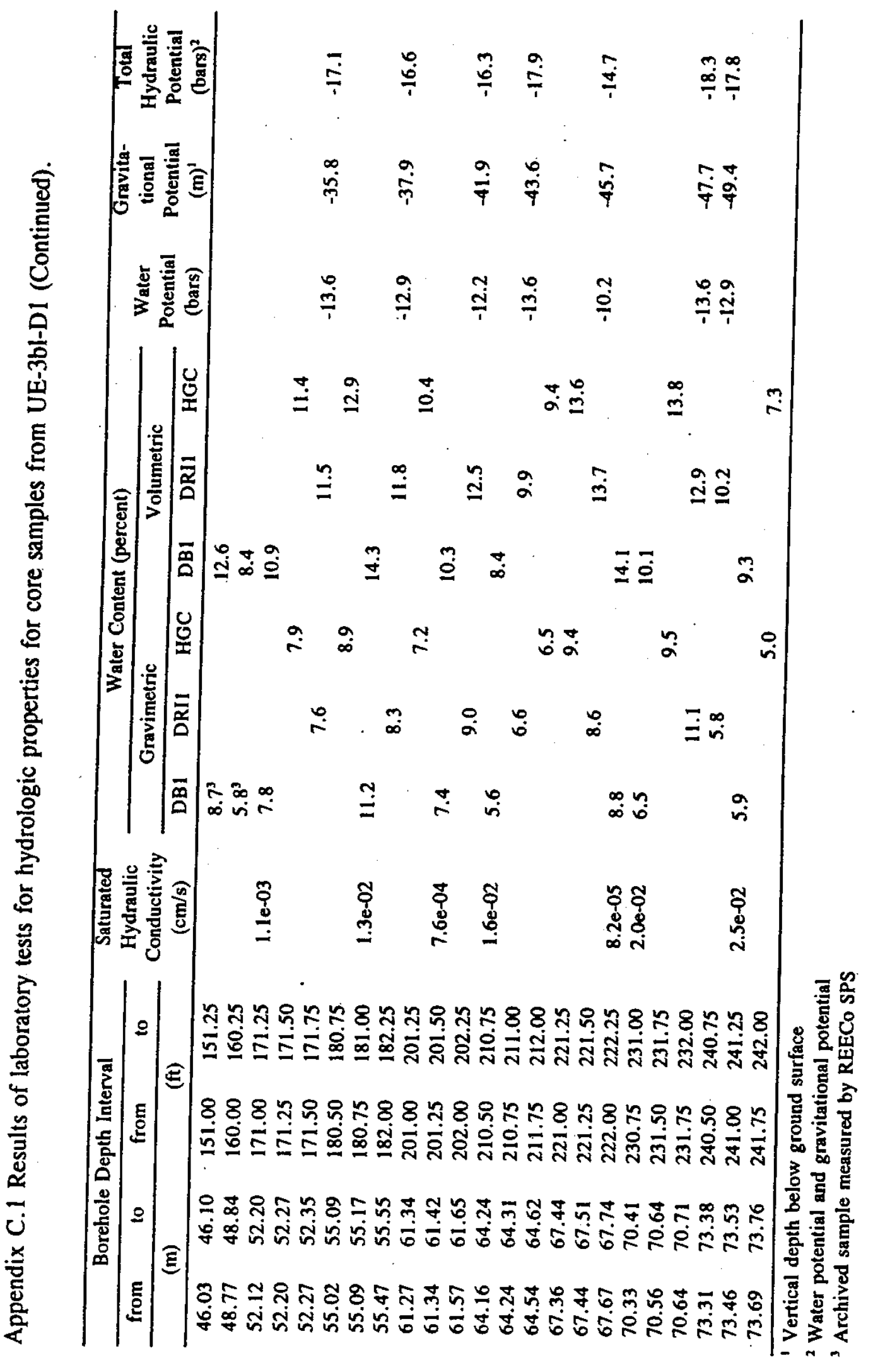




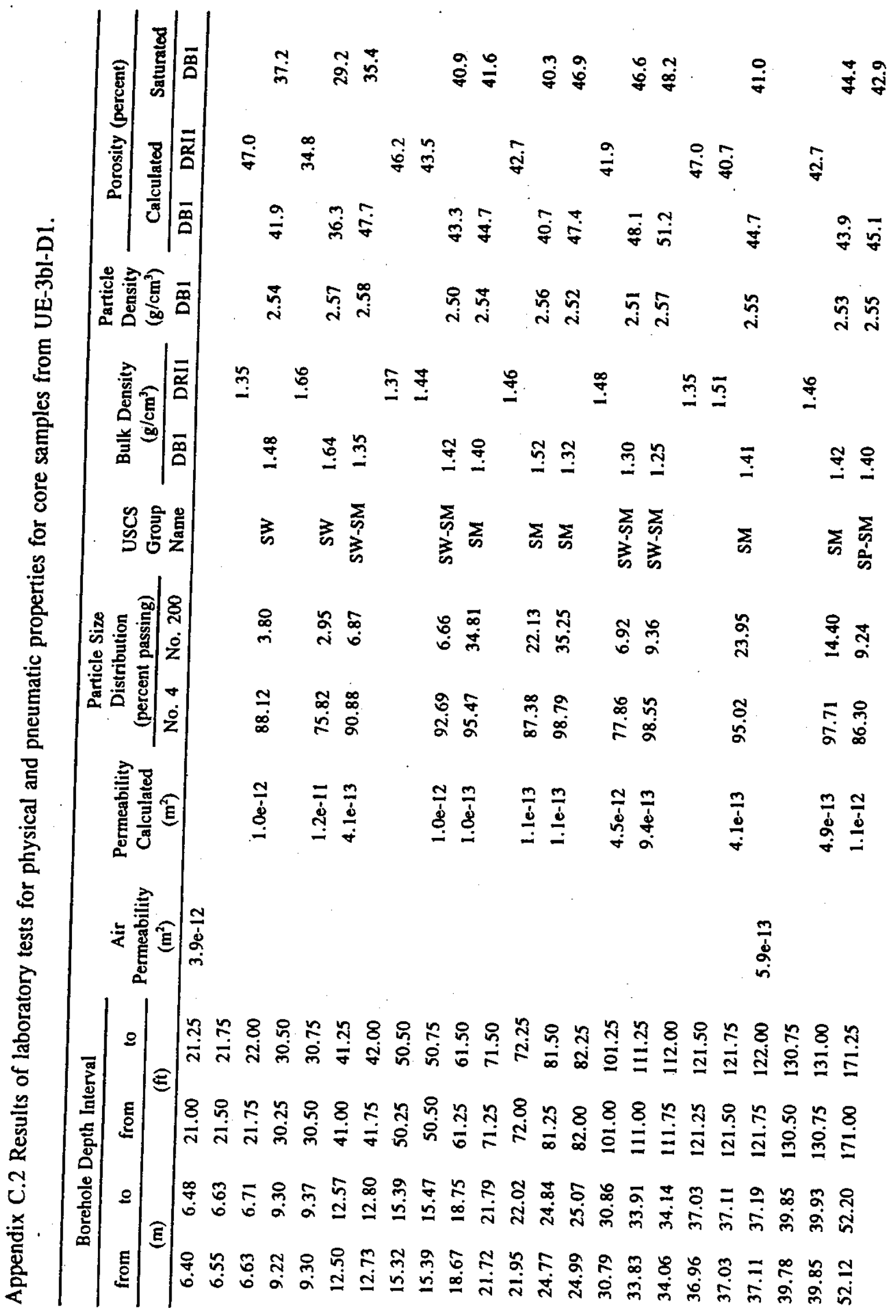




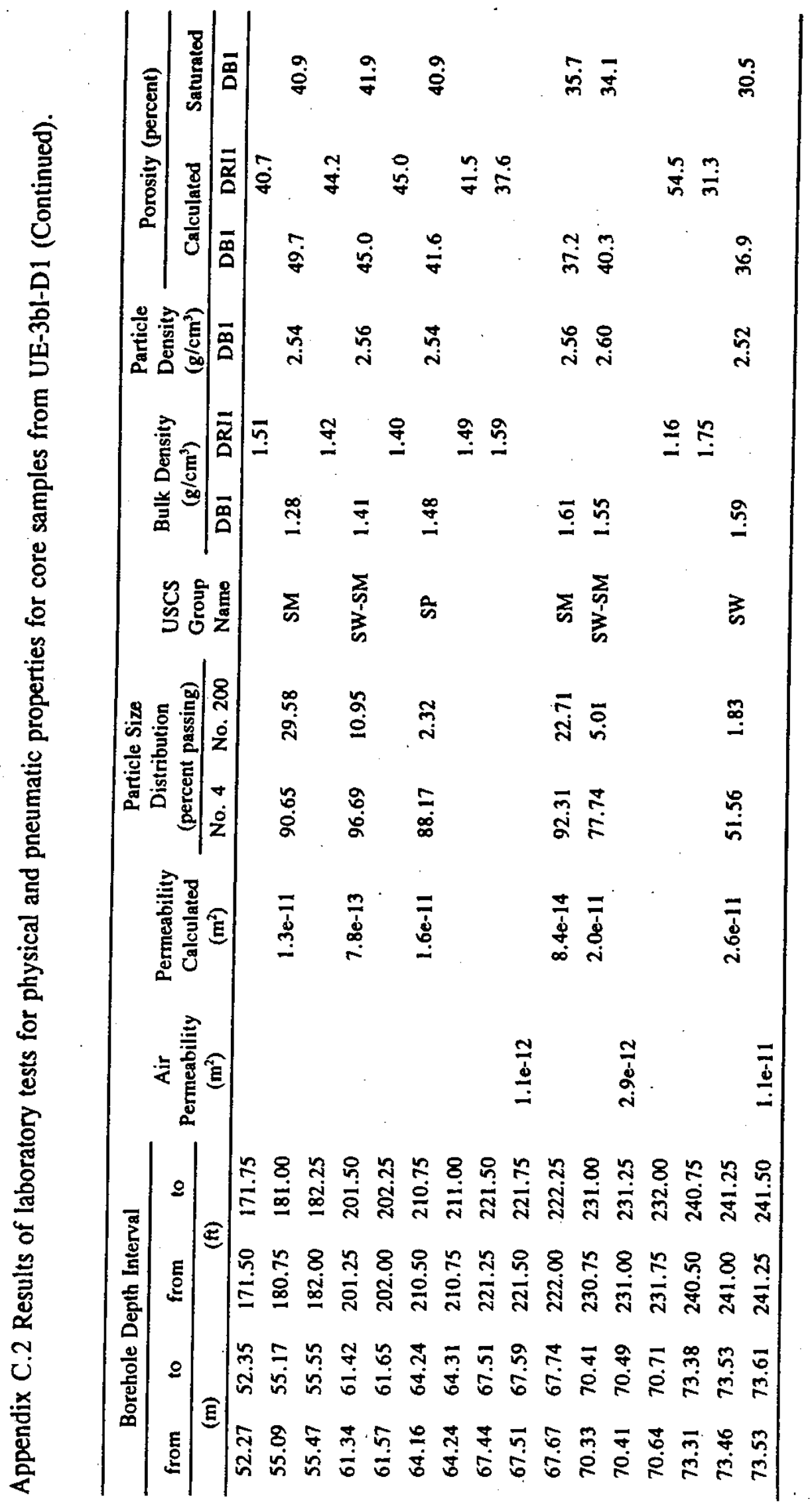




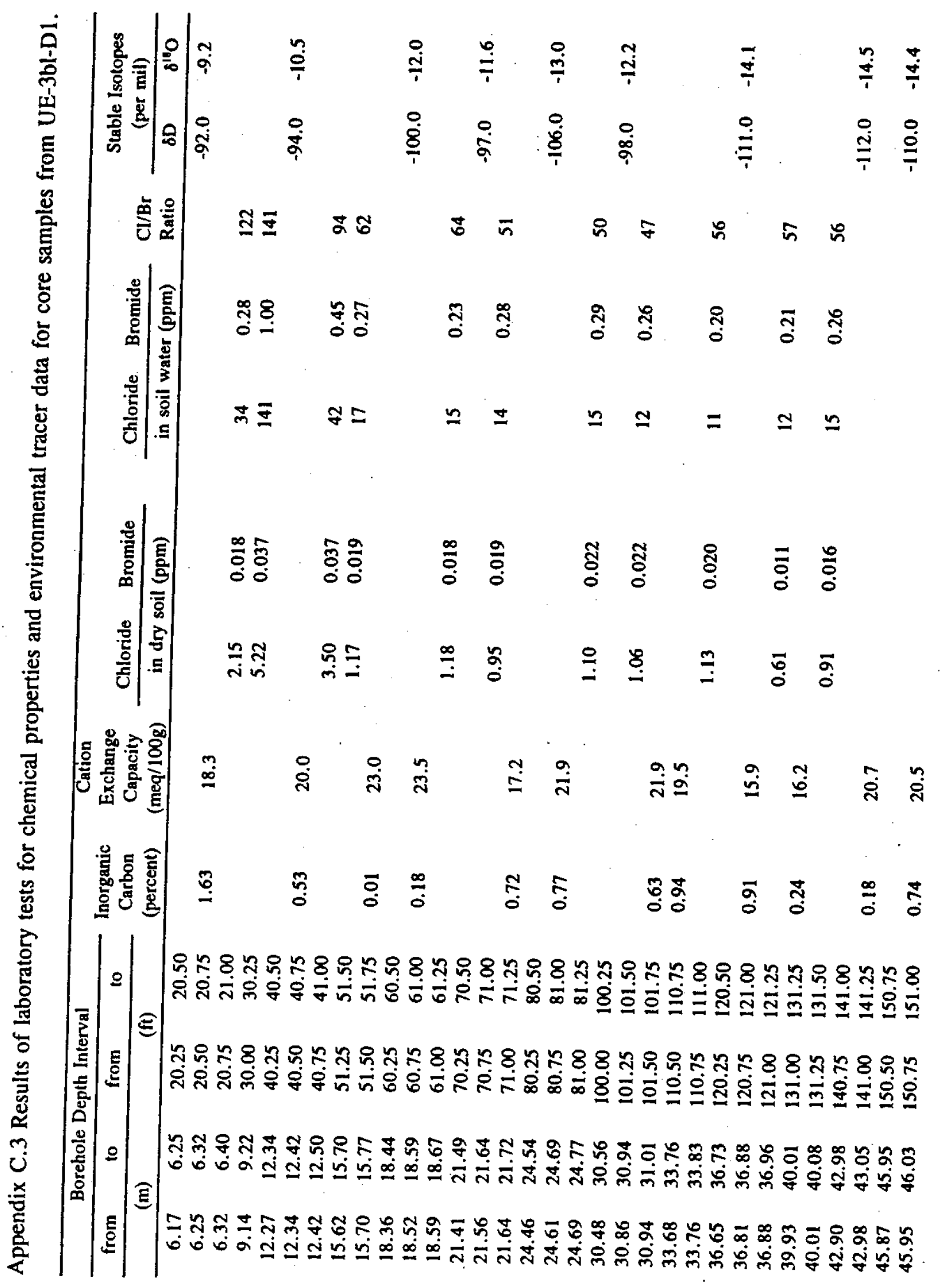




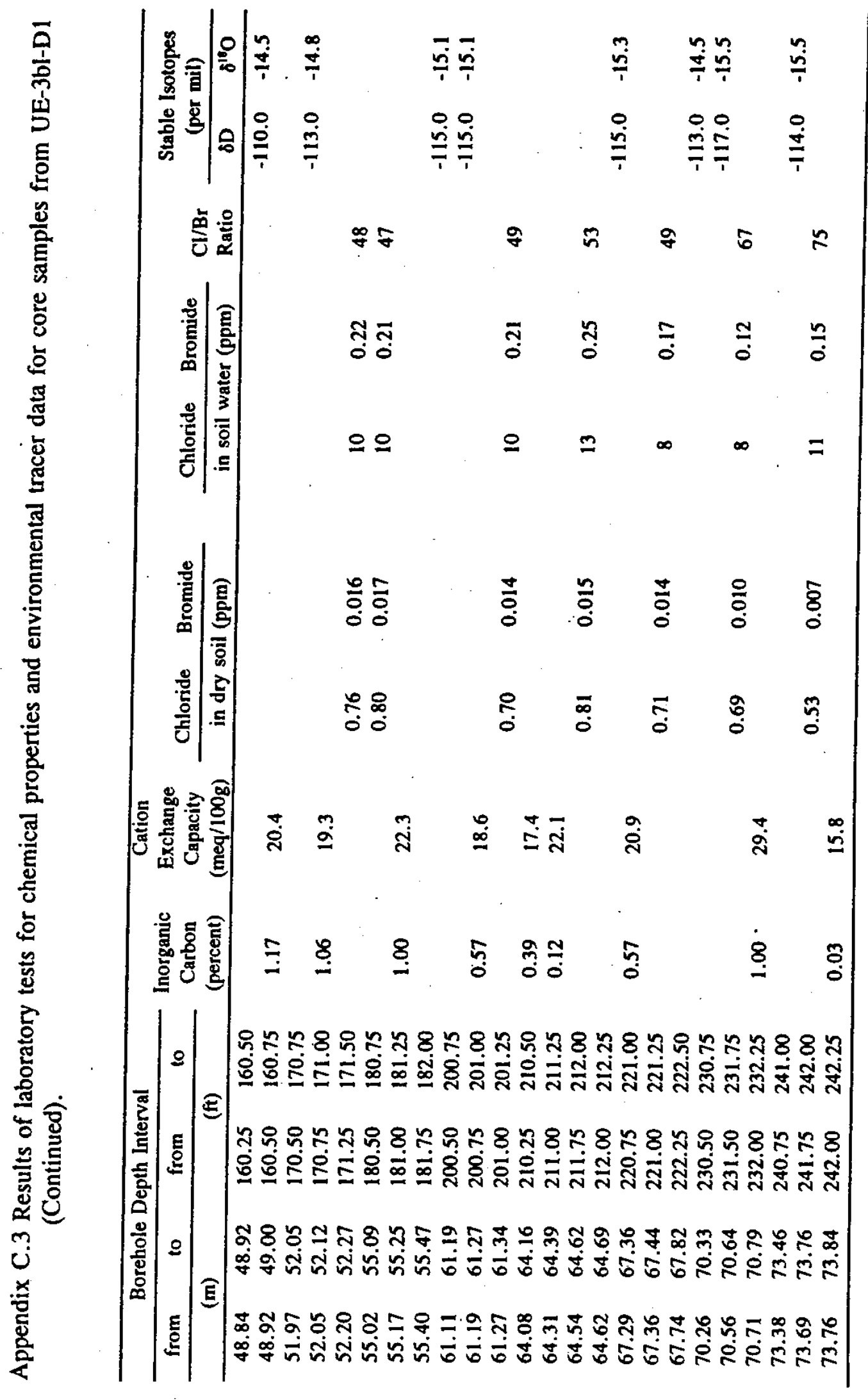


Appendix C.4 Results of gravimetric water content measurements for drill cuttings samples from the UE-3bl-D1.

\begin{tabular}{|c|c|c|c|c|c|c|c|c|c|}
\hline \multicolumn{4}{|c|}{ Borehole Depth Interval } & \multirow{3}{*}{$\begin{array}{c}\text { Gravimetric } \\
\text { Water } \\
\text { Content } \\
\text { (percent) }\end{array}$} & \multicolumn{4}{|c|}{ Borehole Depth Interval } & \multirow{3}{*}{$\begin{array}{c}\text { Gravimetric } \\
\text { Water } \\
\text { Content } \\
\text { (percent) } \\
\end{array}$} \\
\hline from & to & from & to & & from & to & from & to & \\
\hline \multicolumn{2}{|c|}{ (m) } & \multicolumn{2}{|c|}{ (ft) } & & \multicolumn{2}{|c|}{ (m) } & \multicolumn{2}{|c|}{ (ft) } & \\
\hline 3.0 & 3.8 & 10.0 & 12.5 & 3.3 & 38.9 & 39.6 & 127.5 & 130.0 & 5.3 \\
\hline 3.8 & 4.6 & 12.5 & 15.0 & 3.3 & 39.6 & 40.4 & 130.0 & 132.5 & 5.8 \\
\hline 4.6 & 5.3 & 15.0 & 17.5 & 4.3 & 40.4 & 41.1 & 132.5 & 135.0 & 7.0 \\
\hline 5.3 & 6.1 & 17.5 & 20.0 & 3.7 & 41.1 & $41.9^{\circ}$ & 135.0 & 137.5 & 7.6 \\
\hline 6.1 & 6.9 & 20.0 & 22.5 & 5.7 & 41.9 & 42.7 & 137.5 & 140.0 & 6.5 \\
\hline 6.9 & 7.6 & 22.5 & 25.0 & 6.1 & 42.7 & 43.4 & 140.0 & 142.5 & 5.8 \\
\hline 7.6 & 8.4 & 25.0 & 27.5 & 7.0 & 43.4 & 44.2 & 142.5 & 145.0 & 6.4 \\
\hline 8.4 & 9.1 & 27.5 & 30.0 & 6.5 & 44.2 & 45.0 & 145.0 & 147.5 & 5.4 \\
\hline 9.1 & 9.9 & 30.0 & 32.5 & 3.6 & 45.0 & .45 .7 & 147.5 & 150.0 & 5.1 \\
\hline 9.9 & 10.7 & 32.5 & 35.0 & 4.1 & 45.7 & 46.5 & 150.0 & 152.5 & 5.8 \\
\hline 10.7 & 11.4 & 35.0 & 37.5 & 3.4 & 46.5 & 47.2 & 152.5 & 155.0 & 5.0 \\
\hline 11.4 & 12.2 & 37.5 & 40.0 & 3.1 & 47.2 & 48.0 & 155.0 & 157.5 & 6.0 \\
\hline 12.2 & 13.0 & 40.0 & 42.5 & 5.6 & 48.0 & 48.8 & 157.5 & 160.0 & 5.6 \\
\hline 13.0 & 13.7 & 42.5 & 45.0 & 6.4 & 48.8 & 49.5 & 160.0 & 162.5 & 5.8 \\
\hline 13.7 & 14.5 & 45.0 & 47.5 & 4.5 & 49.5 & 50.3 & 162.5 & 165.0 & 5.6 \\
\hline 14.5 & 15.2 & 47.5 & 50.0 & 4.6 & 50.3 & 51.1 & 165.0 & 167.5 & 6.6 \\
\hline 15.2 & 16.0 & 50.0 & 52.5 & 5.3 & 51.1 & 51.8 & 167.5 & 170.0 & 5.2 \\
\hline 16.0 & 16.8 & 52.5 & 55.0 & 6.7 & 51.8 & 52.6 & 170.0 & 172.5 & 6.4 \\
\hline 16.8 & 17.5 & 55.0 & 57.5 & 4.5 & 52.6 & 53.3 & 172.5 & 175.0 & 7.2 \\
\hline 17.5 & 18.3 & 57.5 & 60.0 & 4.2 & 53.3 & 54.1 & 175.0 & 177.5 & 5.4 \\
\hline 18.3 & 19.1 & 60.0 & 62.5 & 6.0 & 54.1 & 54.9 & 177.5 & 180.0 & 6.2 \\
\hline 19.1 & 19.8 & 62.5 & 65.0 & 5.1 & 54.9 & 55.6 & 180.0 & 182.5 & 5.3 \\
\hline 19.8 & 20.6 & 65.0 & 67.5 & 4.5 & 55.6 & 56.4 & 182.5 & 185.0 & 5.7 \\
\hline 20.6 & 21.3 & 67.5 & 70.0 & 4.5 & 56.4 & 57.2 & 185.0 & 187.5 & 6.6 \\
\hline 21.3 & 22.1 & 70.0 & 72.5 & 4.3 & 57.2 & 57.9 & 187.5 & 190.0 & 4.9 \\
\hline 22.1 & 22.9 & 72.5 & 75.0 & 5.1 & 57.9 & 58.7 & 190.0 & 192.5 & 7.2 \\
\hline 22.9 & 23.6 & 75.0 & 77.5 & 4.3 & 58.7 & 59.4 & 192.5 & 195.0 & 6.2 \\
\hline 23.6 & 24.4 & 77.5 & 80.0 & 5.4 & 59.4 & 60.2 & 195.0 & 197.5 & 4.2 \\
\hline 24.4 & 25.1 & 80.0 & 82.5 & 4.6 & 60.2 & 61.0 & 197.5 & 200.0 & 4.5 \\
\hline 25.1 & 25.9 & 82.5 & 85.0 & 6.5 & 61.0 & 61.7 & 200.0 & 202.5 & 5.6 \\
\hline 25.9 & 26.7 & 85.0 & 87.5 & 5.6 & 61.7 & 62.5 & 202.5 & 205.0 & 5.2 \\
\hline 26.7 & 27.4 & 87.5 & 90.0 & 5.2 & 62.5 & 63.2 & 205.0 & 207.5 & 4.8 \\
\hline 27.4 & 28.2 & 90.0 & 92.5 & 5.1 & 63.2 & 64.0 & 207.5 & 210.0 & 5.7 \\
\hline 28.2 & 29.0 & 92.5 & 95.0 & 5.6 & 64.0 & 64.8 & 210.0 & 212.5 & 5.1 \\
\hline 9.0 & 29.7 & 95.0 & 97.5 & 4.2 & 64.8 & 65.5 & 212.5 & 215.0 & 4.4 \\
\hline
\end{tabular}


Appendix C.4 Results of gravimetric water content meaurements for drill cuttings samples from UE-3bl-D1 (Continued).

\begin{tabular}{|c|c|c|c|c|c|c|c|c|c|}
\hline \multicolumn{4}{|c|}{ Borehole Depth Interval } & \multirow{3}{*}{$\begin{array}{c}\text { Gravimetric } \\
\text { Water } \\
\text { Content } \\
\text { (percent) }\end{array}$} & \multicolumn{4}{|c|}{ Borebole Deptb Interval } & \multirow{3}{*}{$\begin{array}{c}\text { Gravimetric } \\
\text { Water } \\
\text { Content } \\
\text { (percent) }\end{array}$} \\
\hline from & to & from & to & & from & to & from & to & \\
\hline \multicolumn{2}{|c|}{ (m) } & \multicolumn{2}{|c|}{$(\mathrm{ft})$} & & \multicolumn{2}{|c|}{ (m) } & \multicolumn{2}{|c|}{ (fi) } & \\
\hline 29.7 & 30.5 & 97.5 & 100.0 & 4.2 & 65.5 & 66.3 & 215.0 & 217.5 & 8.1 \\
\hline 30.5 & 31.2 & 100.0 & 102.5 & 5.1 & 66.3 & 67.1 & 217.5 & 220.0 & 7.6 \\
\hline 31.2 & 32.0 & 102.5 & 105.0 & 3.7 & 67.1 & 67.8 & 220.0 & 222.5 & 4.4 \\
\hline 32.0 & 32.8 & 105.0 & 107.5 & 2.7 & 67.8 & 68.6 & 222.5 & 225.0 & 5.2 \\
\hline 32.8 & 33.5 & 107.5 & 110.0 & 5.3 & 68.6 & 69.3 & 225.0 & 227.5 & 4.9 \\
\hline 33.5 & 34.3 & 110.0 & 112.5 & 5.7 & 69.3 & 70.1 & 227.5 & 230.0 & 3.4 \\
\hline 34.3 & 35.1 & 112.5 & 115.0 & 5.9 & 70.1 & 70.9 & 230.0 & 232.5 & 3.1 \\
\hline 35.1 & 35.8 & 115.0 & 117.5 & 3.5 & 70.9 & 71.6 & 232.5 & 235.0 & 4.1 \\
\hline 35.8 & 36.6 & 117.5 & 120.0 & 5.5 & 71.6 & 72.4 & 235.0 & 237.5 & 7.3 \\
\hline 36.6 & 37.3 & 120.0 & 122.5 & 3.4 & 72.4 & 73.2 & 237.5 & 240.0 & 5.3 \\
\hline 37.3 & 38.1 & 122.5 & 125.0 & 5.1 & 73.2 & 73.9 & 240.0 & 242.5 & 3.3 \\
\hline 38.1 & 38.9 & 125.0 & 127.5 & 5.5 & & & & & \\
\hline
\end{tabular}


Appendix C.5 Results of unenriched tritium analysis for drill cuttings and core samples from UE-3bl-D1.

\begin{tabular}{|c|c|c|c|c|c|c|c|c|c|c|c|}
\hline \multicolumn{4}{|c|}{$\begin{array}{c}\text { Borehole Depth Interval for } \\
\text { Drill Cuttings }\end{array}$} & & & & & & & & \\
\hline from & to & from & to & \multicolumn{4}{|c|}{ Top of sample } & \multicolumn{4}{|c|}{ Middle of sample ${ }^{1}$} \\
\hline \multicolumn{2}{|c|}{ (m) } & \multicolumn{2}{|c|}{$(\mathrm{ft})$} & $(\mathrm{pCi} / \mathrm{L})$ & $(+/-)$ & Low & High & $(\mathrm{pCi} / \mathrm{L})$ & $(+/)$. & Low & High \\
\hline 3.8 & 4.6 & 12.5 & 15.0 & 3,570 & 172 & 3,398 & 3,742 & 3,446 & 175 & 3,271 & 3,621 \\
\hline 18.3 & 19.1 & 60.0 & 62.5 & 760 & 176 & 584 & 936 & 895 & 196 & 699 & 1,091 \\
\hline 45.7 & 46.5 & 150.0 & 152.5 & 3,060 & 280 & 2,780 & 3,340 & 3,310 & 190 & 3,120 & 3,500 \\
\hline 73.2 & 73.9 & 240.0 & 242.5 & 6,470 & 303 & 6,167 & 6,773 & 9,240 & 291 & 8,949 & 9,531 \\
\hline
\end{tabular}

' Subsamples removed from different locations in 3.8-L (1-gal) container

\begin{tabular}{|c|c|c|c|c|c|}
\hline \multicolumn{4}{|c|}{$\begin{array}{c}\text { Borehole Depth Interval for } \\
\text { Core Samples }{ }^{1}\end{array}$} & \multirow{3}{*}{$(\mathrm{pCi} / \mathrm{L})$} & \multirow[b]{3}{*}{$(+/-)$} \\
\hline from & to & from & to & & \\
\hline \multicolumn{2}{|c|}{ (m) } & \multicolumn{2}{|c|}{ (ft) } & & \\
\hline 6.1 & 6.2 & 20.0 & 20.25 & 1350 & 316 \\
\hline 12.2 & 12.3 & 40.0 & 40.25 & 1020 & 245 \\
\hline 18.3 & 18.4 & 60.0 & 60.25 & 471 & 323 \\
\hline 30.5 & 30.6 & 100.0 & 100.25 & 3660 & 316 \\
\hline 36.6 & 36.7 & 120.0 & 120.25 & 1810 & 310 \\
\hline 42.7 & 42.8 & 140.25 & 140.50 & 2320 & 300 \\
\hline 54.9 & 55.0 & 180.25 & 180.50 & 4330 . & 293 \\
\hline 61.0 & 61.1 & 200.25 & 200.50 & 7300 & 1400 \\
\hline 67.0 & 67.1 & 220.0 & 220.25 & 5180. & 439 \\
\hline 73.2 & 73.3 & 240.25 & 240.50 & 5480 & 616 \\
\hline
\end{tabular}

'Samples were archive core segments that were analyzed after the tritium analyses for the drill cuttings showed concentrations above the dectection limit of $350 \mathrm{pCi} / \mathrm{L}$. 


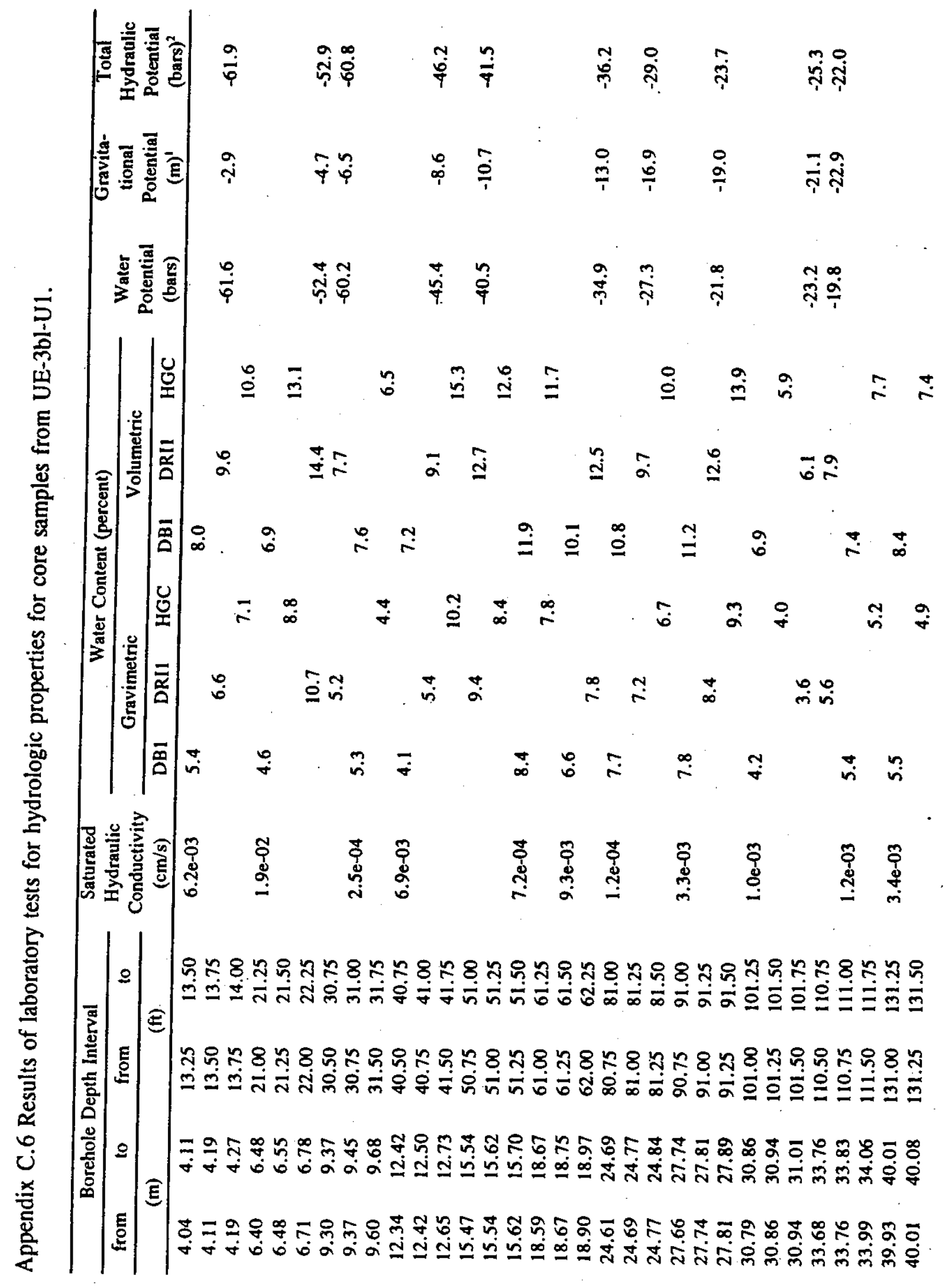




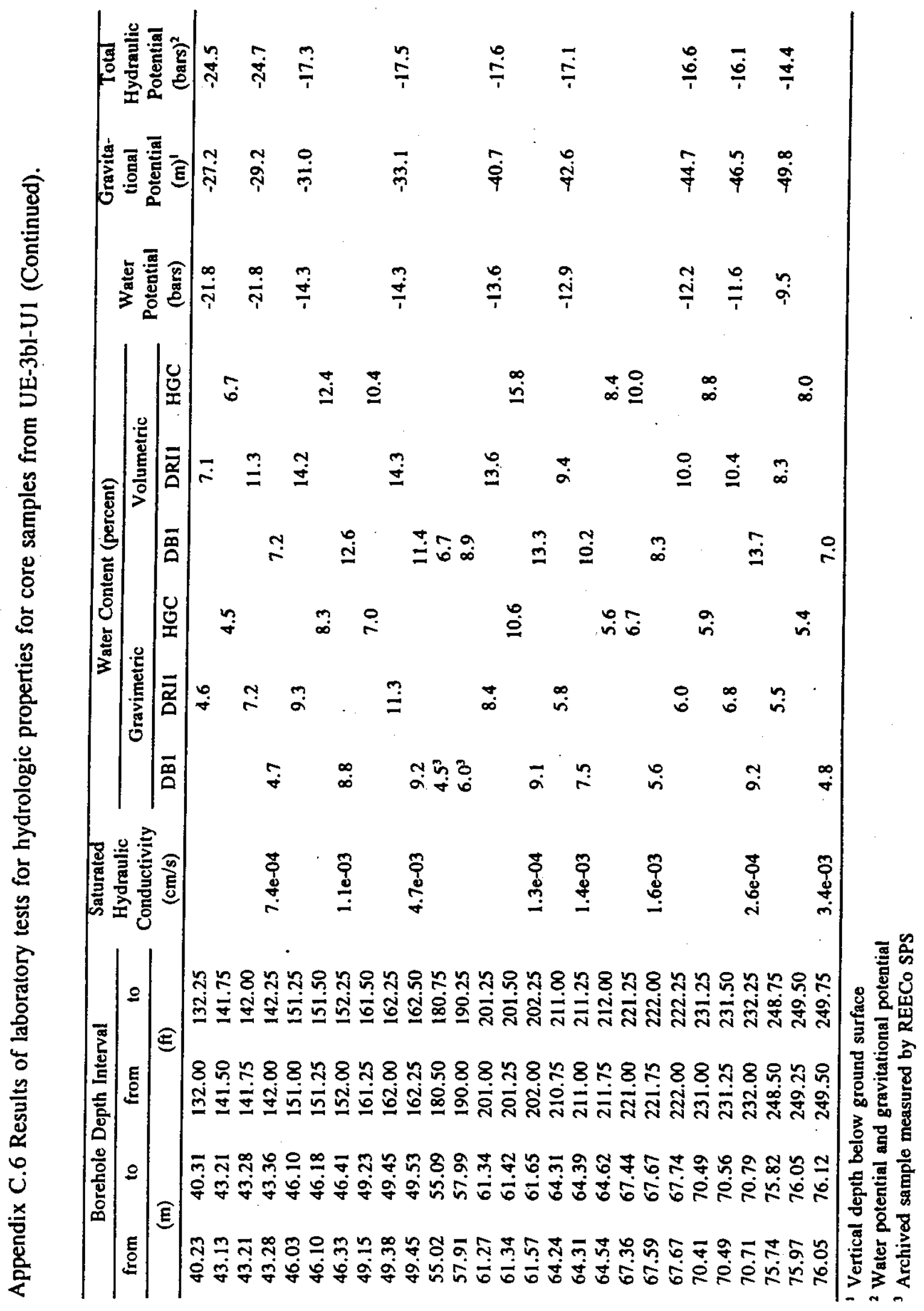




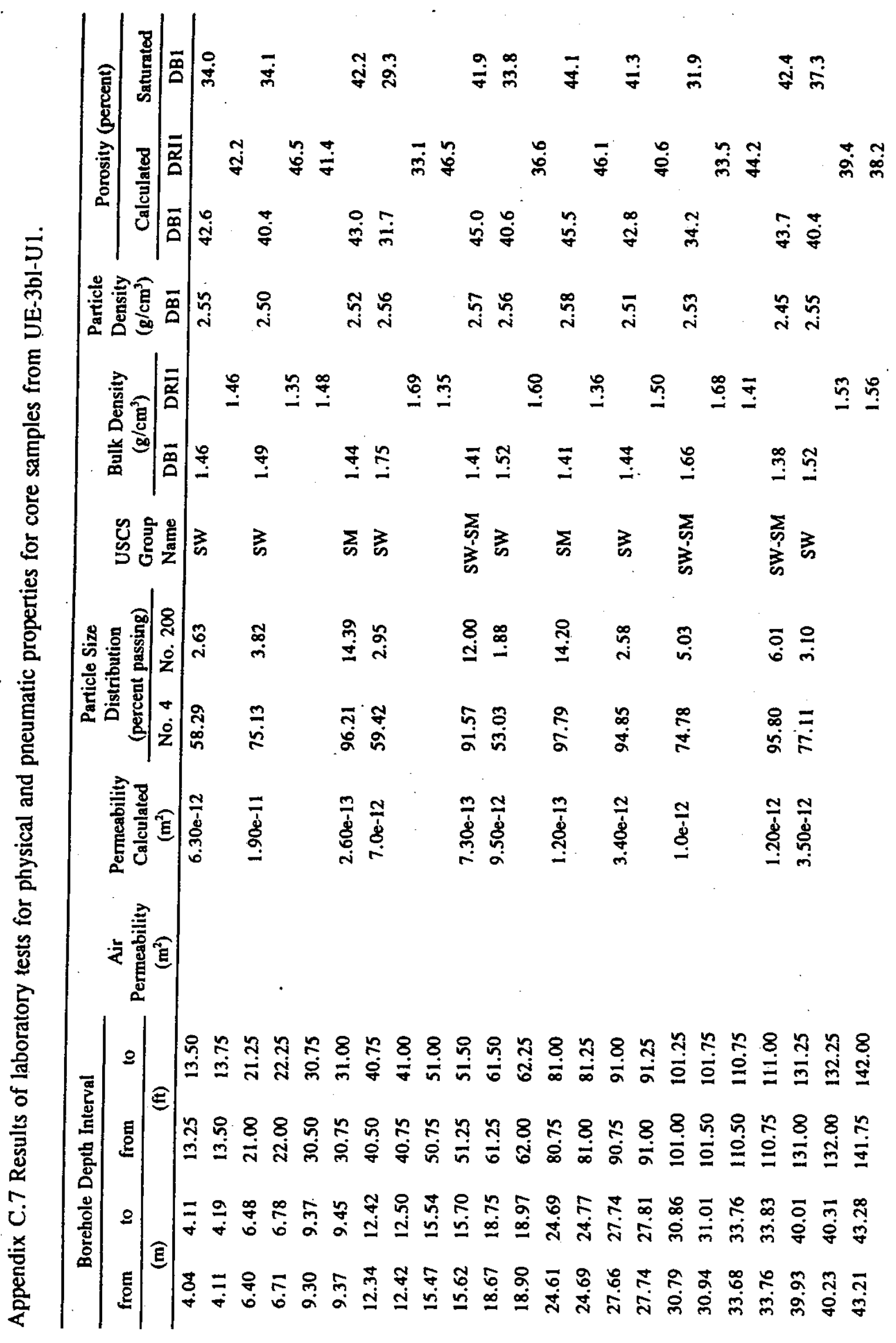




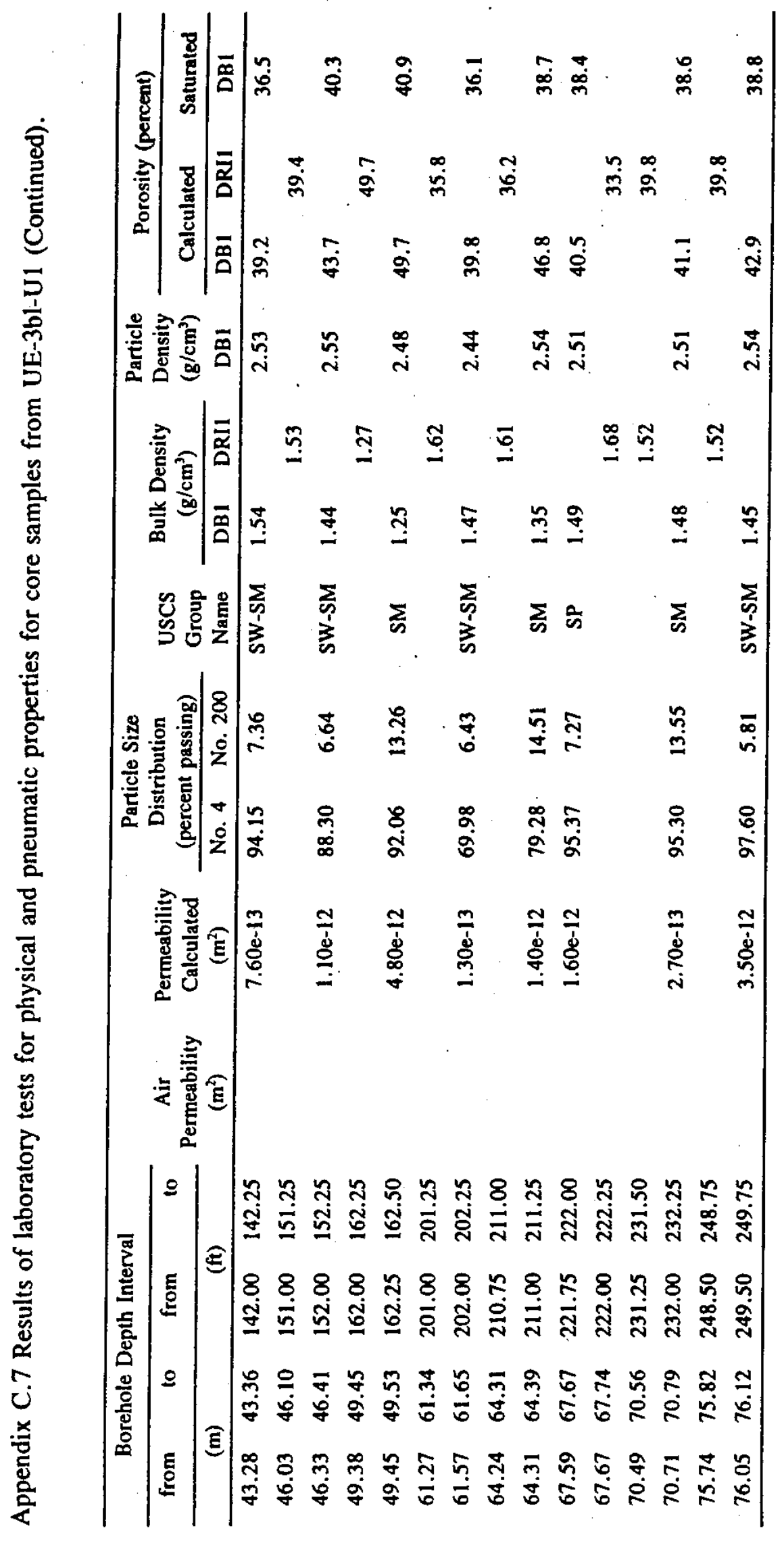




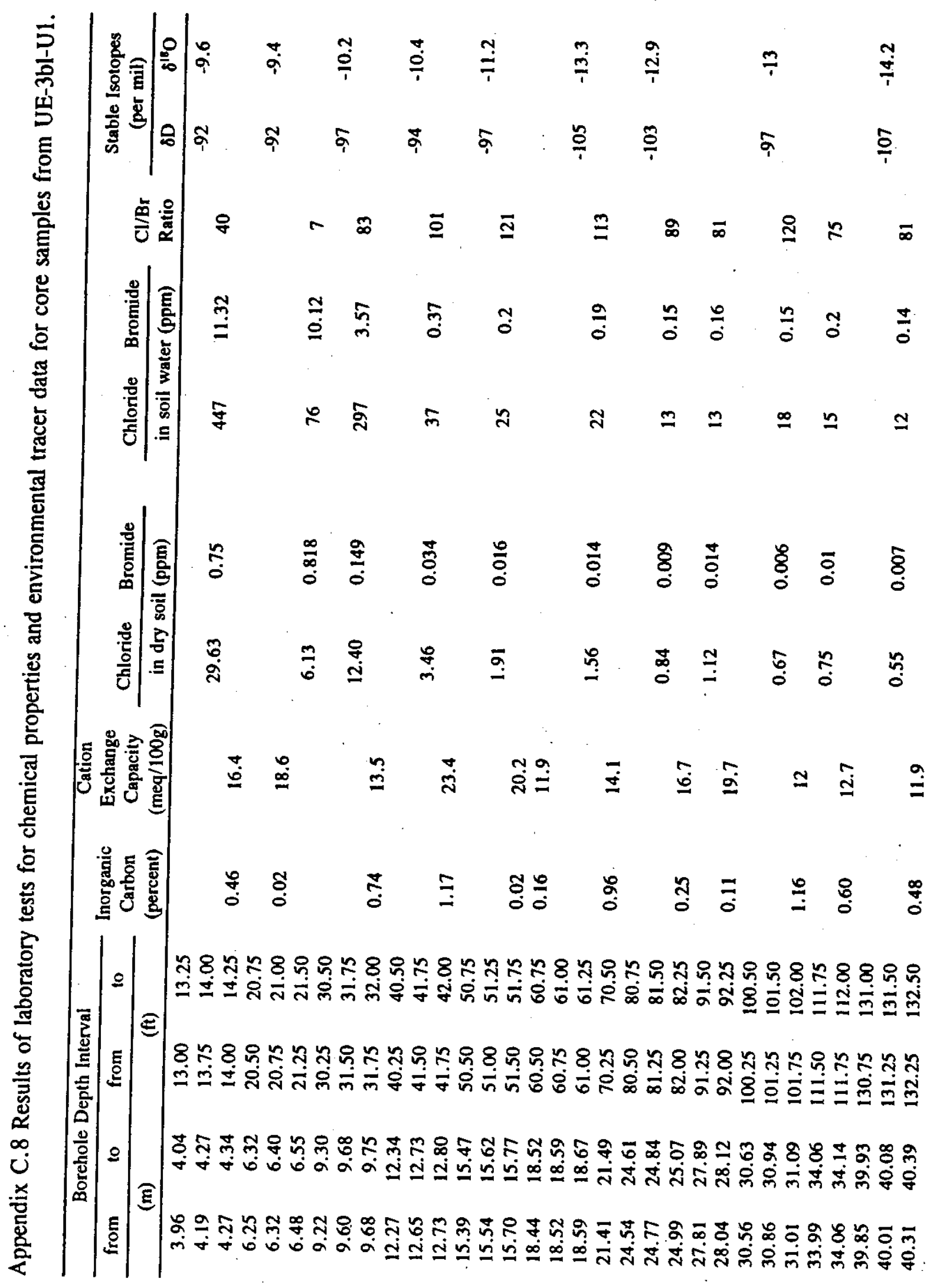




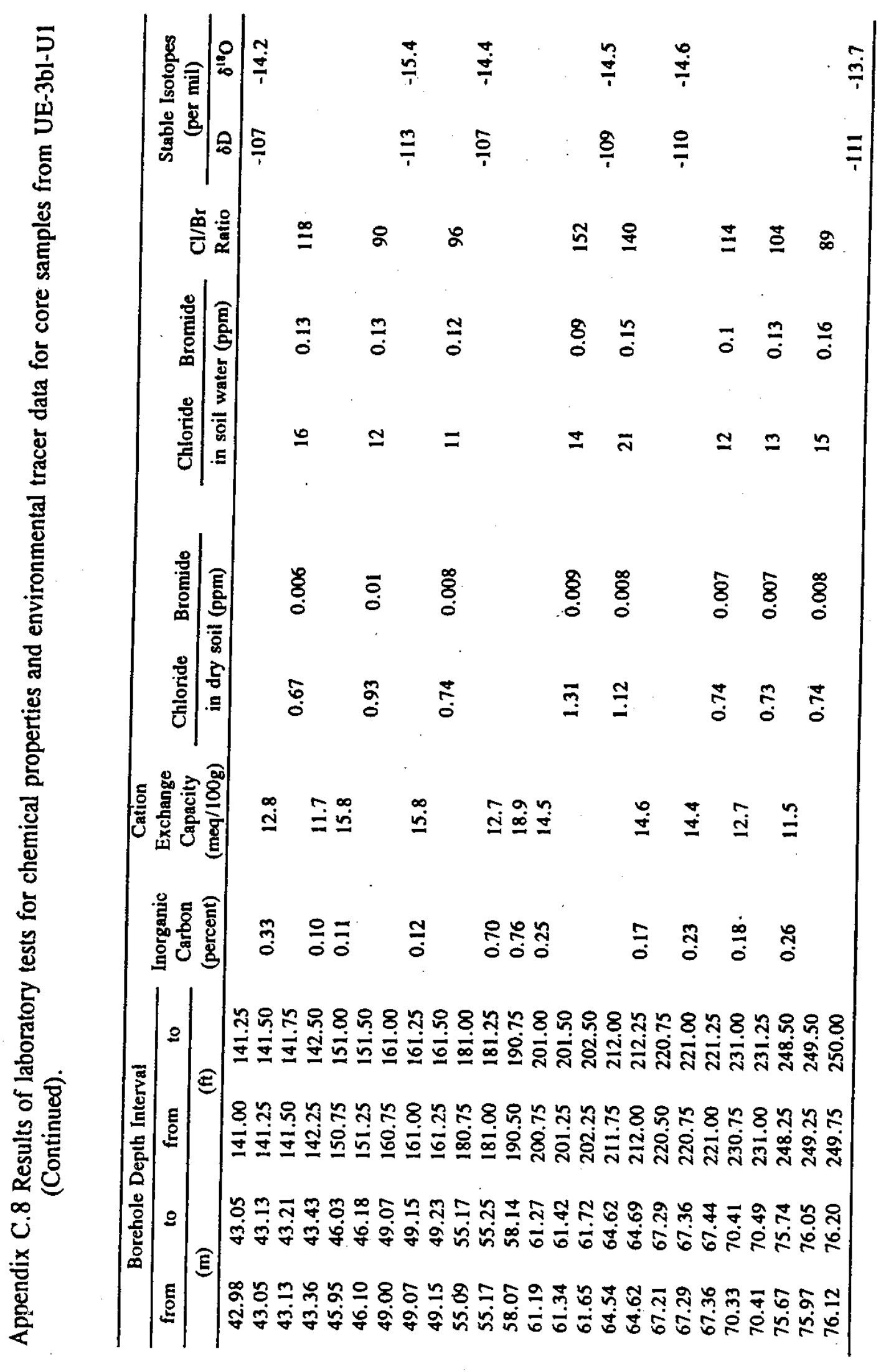


Appendix C.9 Results of gravimetric water content measurements for drill cuttings samples from the UE-3bl-U1.

\begin{tabular}{|c|c|c|c|c|c|c|c|c|c|}
\hline \multicolumn{4}{|c|}{ Borehole Depth Interval } & \multirow{3}{*}{$\begin{array}{c}\text { Gravimetric } \\
\text { Water } \\
\text { Content } \\
\text { (percent) }\end{array}$} & \multicolumn{4}{|c|}{ Borehole Depth Interval } & \multirow{3}{*}{$\begin{array}{c}\text { Gravimetric } \\
\text { Water } \\
\text { Content } \\
\text { (percent) } \\
\end{array}$} \\
\hline from & to & from & to & & from & to & from & to & \\
\hline \multicolumn{2}{|c|}{ (m) } & \multicolumn{2}{|c|}{ (ft) } & & \multicolumn{2}{|c|}{ (m) } & \multicolumn{2}{|c|}{$(\mathrm{ft})$} & \\
\hline 3.0 & 3.8 & 10.0 & 12.5 & 2.9 & 39.6 & 40.4 & 130.0 & 132.5 & 3.0 \\
\hline 3.8 & 4.6 & 12.5 & 15.0 & 3.7 & 40.4 & 41.1 & 132.5 & 135.0 & 4.8 \\
\hline 4.6 & 5.3 & 15.0 & 17.5 & 4.7 & 41.1 & 41.9 & 135.0 & 137.5 & 5.4 \\
\hline 5.3 & 6.1 & 17.5 & 20.0 & 3.2 & 41.9 & 42.7 & 137.5 & 140.0 & 4.2 \\
\hline 6.1 & 6.9 & 20.0 & 22.5 & 4.5 & 42.7 & 43.4 & 140.0 & 142.5 & 5.2 \\
\hline 6.9 & 7.6 & 22.5 & 25.0 & 3.8 & 43.4 & 44.2 & 142.5 & 145.0 & 5.5 \\
\hline 7.6 & 8.4 & 25.0 & 27.5 & 5.2 & 44.2 & 45.0 & 145.0 & 147.5 & 4.8 \\
\hline 8.4 & 9.1 & 27.5 & 30.0 & 5.8 & 45.0 & 45.7 & 147.5 & 150.0 & 4.3 \\
\hline 9.1 & 9.9 & 30.0 & 32.5 & 3.9 & 45.7 & 46.5 & 150.0 & 152.5 & 5.2 \\
\hline 9.9 & 10.7 & 32.5 & 35.0 & 3.7 & 46.5 & 47.2 & 152.5 & 155.0 & 5.8 \\
\hline 10.7 & 11.4 & 35.0 & 37.5 & 3.8 & 47.2 & 48.0 & 155.0 & 157.5 & 4.9 \\
\hline 11.4 & 12.2 & 37.5 & 40.0 & 3.4 & 48.0 & 48.8 & 157.5 & 160.0 & 5.8 \\
\hline 12.2 & 13.0 & 40.0 & 42.5 & 5.1 & 48.8 & 49.5 & 160.0 & 162.5 & 5.6 \\
\hline 13.0 & 13.7 & 42.5 & 45.0 & 5.3 & 49.5 & 50.3 & 162.5 & 165.0 & 4.4 \\
\hline 13.7 & 14.5 & 45.0 & 47.5 & 5.0 & 50.3 & 51.1 & 165.0 & 167.5 & 7.9 \\
\hline 14.5 & 15.2 & 47.5 & 50.0 & 4.7 & 51.1 & 51.8 & 167.5 & 170.0 & 5.1 \\
\hline 15.2 & 16.0 & 50.0 & 52.5 & 7.1 & 51.8 & 52.6 & 170.0 & 172.5 & 5.1 \\
\hline 16.0 & 16.8 & 52.5 & 55.0 & 4.9 & 52.6 & 53.3 & 172.5 & 175.0 & 6.9 \\
\hline 16.8 & 17.5 & 55.0 & 57.5 & 5.2 & 53.3 & 54.1 & 175.0 & 177.5 & 4.3 \\
\hline 17.5 & 18.3 & 57.5 & 60.0 & 5.3 & 54.1 & 54.9 & 177.5 & 180.0 & 3.7 \\
\hline 18.3 & 19.1 & 60.0 & 62.5 & 5.1 & 54.9 & 55.6 & 180.0 & 182.5 & 4.6 \\
\hline 19.1 & 19.8 & 62.5 & 65.0 & 5.5 & 55.6 & 56.4 & 182.5 & 185.0 & 4.9 \\
\hline 19.8 & 20.6 & 65.0 & 67.5 & 3.8 & 56.4 & 57.2 & 185.0 & 187.5 & 4.7 \\
\hline 20.6 & 21.3 & 67.5 & 70.0 & 5.0 & 57.2 & 57.9 & 187.5 & 190.0 & 4.8 \\
\hline 21.3 & 22.1 & 70.0 & 72.5 & 4.3 & 57.9 & 58.7 & 190.0 & 192.5 & 4.8 \\
\hline 22.1 & 22.9 & 72.5 & 75.0 & 5.1 & 58.7 & 59.4 & 192.5 & 195.0 & 5.2 \\
\hline 22.9 & 23.6 & 75.0 & 77.5 & 4.1 & 59.4 & 60.2 & 195.0 & 197.5 & 4.3 \\
\hline 23.6 & 24.4 & 77.5 & 80.0 & 7.2 & 60.2 & 61.0 & 197.5 & 200.0 & 4.6 \\
\hline 24.4 & 25.1 & 80.0 & 82.5 & 5.8 & 61.0 & 61.7 & 200.0 & 202.5 & 7.0 \\
\hline 25.1 & 25.9 & 82.5 & 85.0 & 4.7 & 61.7 & 62.5 & 202.5 & 205.0 & 6.4 \\
\hline 25.9 & 26.7 & 85.0 & 87.5 & 5.8 & 62.5 & 63.2 & 205.0 & 207.5 & 10.2 \\
\hline 26.7 & 27.4 & 87.5 & 90.0 & 5.7 & 63.2 & 64.0 & 207.5 & 210.0 & 3.8 \\
\hline 27.4 & 28.2 & 90.0 & 92.5 & 4.9 & 64.0 & 64.8 & 210.0 & 212.5 & 7.6 \\
\hline 28.2 & 29.0 & 92.5 & 95.0 & 6.2 & 64.8 & 65.5 & 212.5 & 215.0 & 5.0 \\
\hline 29.0 & 29.7 & 95.0 & 97.5 & 7.2 & 65.5 & 66.3 & 215.0 & 217.5 & 5.4 \\
\hline
\end{tabular}


Appendix C.9 Results of gravimetric water content measurements for drill cuttings samples from UE-3bl-Ul (Continued).

\begin{tabular}{|c|c|c|c|c|c|c|c|c|c|}
\hline \multicolumn{4}{|c|}{ Borehole Depth Interval } & \multirow{3}{*}{$\begin{array}{c}\text { Gravimetric } \\
\text { Water } \\
\text { Content } \\
\text { (percent) }\end{array}$} & \multicolumn{4}{|c|}{ Borebole Depth Interval } & \multirow{3}{*}{$\begin{array}{c}\text { Gravimetric } \\
\text { Water } \\
\text { Content } \\
\text { (percent) }\end{array}$} \\
\hline from & to & from & to & & from & to & from & to & \\
\hline \multicolumn{2}{|c|}{ (m) } & \multicolumn{2}{|c|}{ (ft) } & & \multicolumn{2}{|c|}{ (m) } & \multicolumn{2}{|c|}{ (ft) } & \\
\hline 29.7 & 30.5 & 97.5 & 100.0 & 4.2 & 66.3 & 67.1 & 217.5 & 220.0 & 4.5 \\
\hline 30.5 & 31.2 & 100.0 & 102.5 & 3.6 & 67.1 & 67.8 & 220.0 & 222.5 & 4.0 \\
\hline 31.2 & 32.0 & 102.5 & 105.0 & 5.0 & 67.8 & 68.6 & 222.5 & 225.0 & 5.7 \\
\hline 32.0 & 32.8 & 105.0 & 107.5 & 5.0 & 68.6 & 69.3 & 225.0 & 227.5 & 5.4 \\
\hline 32.8 & 33.5 & 107.5 & 110.0 & 4.1 & 69.3 & 70.1 & 227.5 & 230.0 & 5.1 \\
\hline 33.5 & 34.3 & 110.0 & 112.5 & 6.1 & 70.1 & 70.9 & 230.0 & 232.5 & 7.5 \\
\hline 34.3 & 35.1 & 112.5 & 115.0 & 5.3 & 70.9 & 71.6 & 232.5 & 235.0 & 5.4 \\
\hline 35.1 & 35.8 & 115.0 & 117.5 & 5.8 & 71.6 & 72.4 & 235.0 & 237.5 & 3.9 \\
\hline 35.8 & 36.6 & 117.5 & 120.0 & 4.6 & 72.4 & 73.2 & 237.5 & 240.0 & 7.7 \\
\hline 36.6 & 37.3 & 120.0 & 122.5 & 5.2 & 73.2 & 73.9 & 240.0 & 242.5 & 5.7 \\
\hline 37.3 & 38.1 & 122.5 & 125.0 & 5.7 & 73.9 & 74.7 & 242.5 & 245.0 & 5.0 \\
\hline 38.1 & 38.9 & 125.0 & 127.5 & 4.8 & 74.7 & 75.4 & 245.0 & 247.5 & 5.3 \\
\hline 38.9 & 39.6 & 127.5 & 130.0 & 4.6 & & & & & \\
\hline
\end{tabular}


Appendix C.10 Moisture retention data for core samples from UE-3bl-D1.

\begin{tabular}{|c|c|c|c|c|c|c|c|c|}
\hline $\begin{array}{c}\text { Borehole } \\
\text { Sample } \\
\text { Depth } \\
\text { (tt) }\end{array}$ & $\begin{array}{c}\text { Volumetric } \\
\text { Water } \\
\text { Content } \\
\text { (percent) }\end{array}$ & $\begin{array}{c}\text { Water } \\
\text { Potential } \\
\text { (bars) }\end{array}$ & $\begin{array}{l}\text { Borehole } \\
\text { Sampie } \\
\text { Depth } \\
\text { (f) }\end{array}$ & $\begin{array}{c}\text { Volumetric } \\
\text { Water } \\
\text { Content } \\
\text { (percent) } \\
\end{array}$ & $\begin{array}{c}\text { Water } \\
\text { Potential } \\
\text { (bars) }\end{array}$ & $\begin{array}{l}\text { Borehole } \\
\text { Sample } \\
\text { Depth } \\
\text { (ft) }\end{array}$ & $\begin{array}{c}\text { Volumetric } \\
\text { Water } \\
\text { Content } \\
\text { (percent) } \\
\end{array}$ & $\begin{array}{c}\text { Water } \\
\text { Potential } \\
\text { (bars) }\end{array}$ \\
\hline \multirow[t]{8}{*}{21} & 12.5 & -17.10 & 81 & 11.4 & -18.80 & 181 & 10.1 & -22.50 \\
\hline & 14.3 & -3.70 & & 15.3 & -3.30 & & 14.3 & -4.90 \\
\hline & 17.7 & -1.00 & & 19.1 & -1.00 & & 18.9 & -1.00 \\
\hline & 18.4 & -0.50 & & 20.6 & -0.50 & & 20.6 & -0.50 \\
\hline & 23.3 & -0.10 & & 36.4 & -0.10 & & 26.4 & -0.10 \\
\hline & 25.9 & -0.06 & & 39.9 & -0.06 & & 37.3 & -0.05 \\
\hline & 29.9 & -0.02 & & 44.4 & -0.02 & & 38.5 & -0.03 \\
\hline & 37.2 & 0.00 & & 46.9 & 0.00 & & 40.9 & 0.00 \\
\hline \multirow[t]{8}{*}{31} & 7.6 & -17.34 & 101 & 11.0 & -26.00 & 201 & 8.5 & -21.10 \\
\hline & 8.7 & -3.07 & & 13.2 & -3.80 & & 10.8 & -4.60 \\
\hline & 13.0 & -1.00 & & 18.9 & -0.98 & & 13.6 & -1.00 \\
\hline & 14.3 & -0.50 & & 20.5 & -0.50 & & 14.2 & -0.50 \\
\hline & 17.4 & -0.10 & & 25.4 & -0.11 & & $22.2^{\circ}$ & -0.10 \\
\hline & 25.5 & -0.05 & & 32.9 & -0.05 & & 30.8 & -0.06 \\
\hline & 26.9 & -0.03 & & 41.3 & -0.02 . & & 40.1 & -0.02 \\
\hline & 29.2 & 0.00 & & 46.6 & 0.00 & & 41.9 & 0.00 \\
\hline \multirow[t]{8}{*}{41} & 10.6 & -18.24 & 111 & 14.2 & -15.93 & 211 & 7.8 & -18.19 \\
\hline & 12.7 & -3.61 & & 17.2 & -3.93 & & 9.1 & -2.57 \\
\hline & 17.4 & $-1,00$ & & 22.5 & -0.98 & & {$[3.0$} & -0.98 \\
\hline & 19.2 & -0.50 & & 23.7 & -0.50 & & 13.6 & -0.50 \\
\hline & 25.3 & -0.10 & & 31.8 & -0.10 & & 16.4 & -0.10 \\
\hline & 32.7 & -0.05 & & 36.6 & -0.05 & & 18.1 & -0.05 \\
\hline & 34.0 & -0.03 & & 46.4 & -0.01 & & 35.8 & -0.01 \\
\hline & 35.4 & 0.00 & . & 48.2 & 0.00 & & 40.9 & 0.00 \\
\hline \multirow[t]{8}{*}{51} & 12.5 & -15.30 & 122 & 7.7 & -16.50 & 222 & 10.3 & -19.80 \\
\hline & 14.2 & -3.20 & & 10.0 & -3.60 & & 12.9 & -3.00 \\
\hline & 19.6 & -1.00 & & 14.0 & -0.98 & & 16.7 & -0.98 \\
\hline & 20.7 & -0.50 & & 16.6 & -0.50 & & 19.1 & -0.50 \\
\hline & 25.0 & -0.10 & & 30.1 & -0.11 & & 26.9 & -0.11 \\
\hline & 30.5 & -0.06 & & 36.4 & -0.05 & & 31.3 & -0.05 \\
\hline & .34 .3 & -0.02 & & 38.9 & -0.02 & & 34.0 & -0.02 \\
\hline & 40.9 & 0.00 & & 41.0 & 0.00 & & 35.7 & 0.00 \\
\hline \multirow[t]{8}{*}{61} & & -16.10 & 131 & 8.7 & -16.70 & 231 & 8.8 & -16.20 \\
\hline & 15.7 & -3.40 & 101 & 10.1 & -3.70 & & 10.4 & -2.80 \\
\hline & 20.4 & -1.00 & & 15.1 & -0.98 & & 15.3 & -0.98 \\
\hline & 21.7 & -0.50 & & 16.5 & -0.50 & & 16.6 & -0.50 \\
\hline & 29.3 & -0.10 & & 27.5 & -0.10 & & 18.0 & -0.11 \\
\hline & 32.7 & -0.06 & & 36.3 & -0.05 & & 20.1 & -0.05 \\
\hline & 36.3 & -0.02 & & 41.6 & -0.01 & & 24.6 & -0.02 \\
\hline & 41.6 & 0.00 & & 44.4 & 0.00 & & 34.1 & 0.00 \\
\hline \multirow[t]{8}{*}{72} & 10.9 & -17.40 & 171 & 10.0 & -15.20 & 241 & 8.3 & -17.80 \\
\hline & 12.8 & -4.70 & & 11.3 & -3.10 & & 9.2 & -2.70 \\
\hline & 17.7 & -1.00 & & 15.0 & -0.98 & & 13.7 & -1.00 \\
\hline & 20.0 & -0.50 & & 16.4 & -0.50 & & 14.9 & -0.50 \\
\hline & 31.7 & -0.10 & & 22.6 & -0.11 & & 16.5 & -0.10 \\
\hline & 39.3 & -0.05 & & 29.2 & -0.05 & & 26.3 & -0.05 \\
\hline & 40.0 & -0.03 & & 38.0 & -0.02 & & 28.1 & -0.03 \\
\hline & 40.3 & 0.00 & & 42.9 & 0.00 & & 30.5 & 0.00 \\
\hline
\end{tabular}


Appendix C.11 Moisture retention data for core samples from UE-3bl-U1.

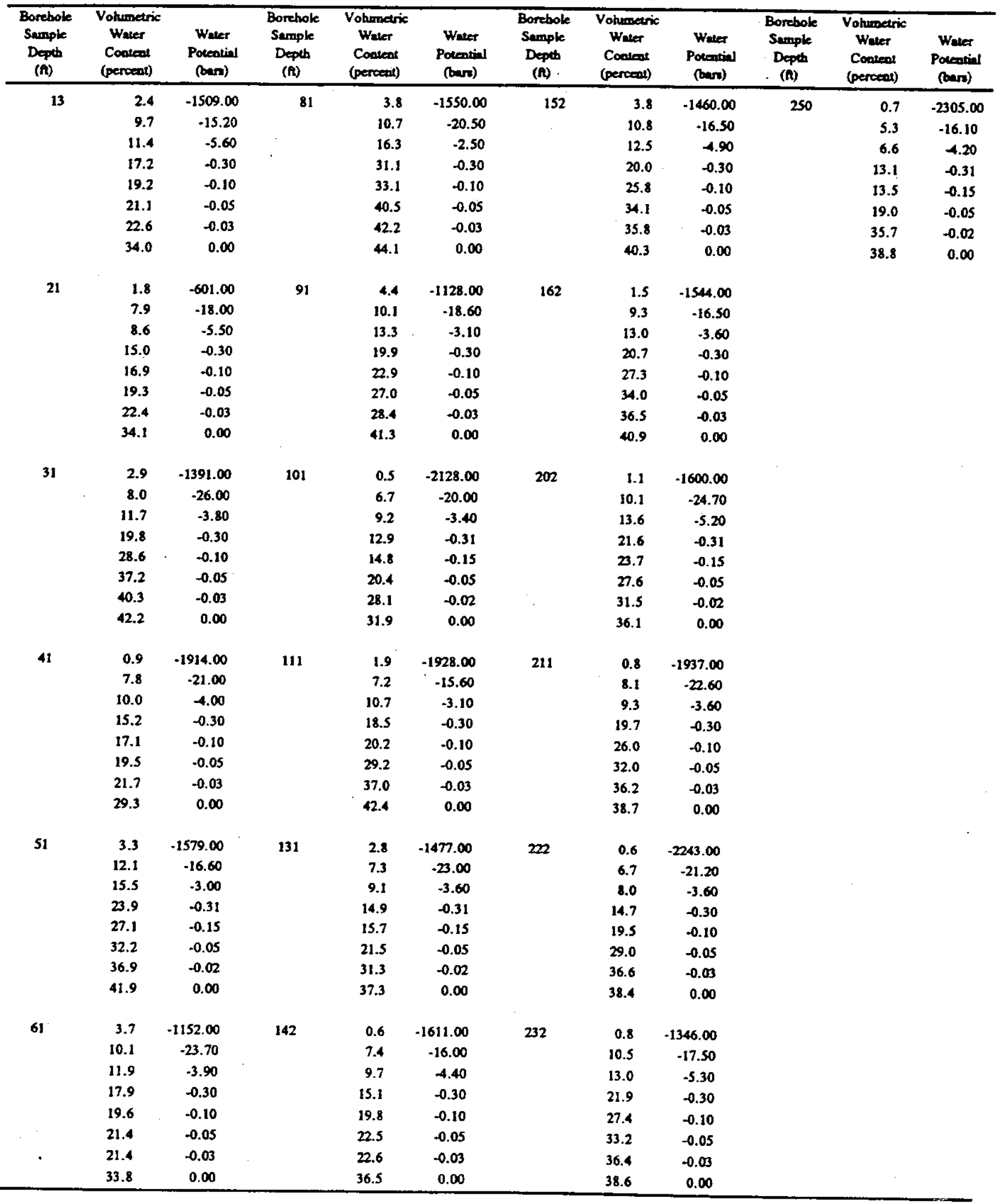


Appendix C.12 Parameters required to calculate unsaturated hydraulic conductivity for core samples from the U3ax/bl Exploratory Boreholes.

\begin{tabular}{|c|c|c|c|c|c|c|c|c|c|}
\hline \multicolumn{5}{|c|}{ UE-3bi-DI } & \multicolumn{5}{|c|}{ UE-3bi-U1 } \\
\hline $\begin{array}{c}\text { Borebole } \\
\text { Serple } \\
\text { Depth } \\
\text { (t) }\end{array}$ & $\begin{array}{c}\text { Saturated } \\
\text { Hydraulic } \\
\text { Conducti- } \\
\text { vity } \\
(\mathrm{cm} / \mathrm{s})\end{array}$ & $\begin{array}{c}\text { Residual } \\
\text { Volumetric } \\
\text { Water } \\
\text { Content } \\
\text { (percent) } \\
\theta_{r} \\
\end{array}$ & $\begin{array}{c}\alpha \\
\left(\mathrm{cm}^{-1}\right)\end{array}$ & $\mathrm{n}^{\prime}$ & $\begin{array}{c}\text { Borchole } \\
\text { Sample } \\
\text { Depth } \\
\text { (fi) }\end{array}$ & $\begin{array}{c}\text { Saturnted } \\
\text { Hydraulic } \\
\text { Conducti- } \\
\text { vity } \\
(\mathrm{cm} / \mathrm{s})\end{array}$ & $\begin{array}{c}\text { Residual } \\
\text { Volumetric } \\
\text { Water } \\
\text { Content } \\
\text { (percenl) } \\
\theta_{r} \\
\end{array}$ & $\begin{array}{c}\alpha \\
\left(\mathrm{cm}^{-1}\right)\end{array}$ & $n^{\prime}$ \\
\hline 22 & $1.0 e-03$ & 7.4 & 0.137 & 1.23 & 13 & $6.2 e-03$ & 2.4 & 0.504 & 1.15 \\
\hline 31 & $1.2 e-02$ & 6.4 & 0.026 & 1.45 & 21 & $1.9 e-02$ & 1.8 & 0.413 & 1.18 \\
\hline 41 & $4.0<-04$ & 8.6 & 0.017 & 1.43 & 31 & $2.5 e-04$ & 2.9 & 0.019 & 1.44 \\
\hline 51 & $9.9 e-04$ & 4.9 & 0.096 & 1.22 & 41 & $6.9 e-03$ & 0.9 & 0.182 & 1.17 \\
\hline 6) & $1.0 e-04$ & 1.5 & 0.067 & 1.19 & 51 & $7.2 غ-04$ & 3.3 & 0.061 & 1.19 \\
\hline 72 & $1.1 e-04$ & 10.5 & 0.009 & 1.68 & 61 & $9.3 e-03$ & 3.7 & 0.776 & 1.13 \\
\hline 81 & $1.1 e-04$ & 10.2 & 0.015 & 1.54 & 81 & $1.2 c-04$ & 3.8 & 0.016 & 1.25 \\
\hline 101 & $4.4 e-03$ & 9.9 & 0.046 & 1.43 & 91 & $3.3 e-03$ & 4.4 & 0.293 & 1.17 \\
\hline 111 & $9.2 e-04$ & 9.9 & 0.049 & 1.31 & 101 & $1.0 \mathrm{e}-03$ & 0.5 & 0.048 & 1.49 \\
\hline 122 & $4.0<-04$ & 6.8 & 0.012 & 1.64 & 111 & $1.2 e-03$ & 1.9 & 0.053 & 1.34 \\
\hline 131 & $4.8 e-04$ & 7.4 & 0.023 & 1.55 & 131 & $3.4 e-03$ & 2.8 & 0.073 & 1.38 \\
\hline 171 & $1.1 e-03$ & 10.0 & 0.036 & 1.61 & 142 & $7.4 e-04$ & 0.6 & 0.328 & 1.19 \\
\hline 181 & $1.3 e-02$ & 8.8 & 0.023 & 1.41 & 152 & $1.1 c-03$ & 3.8 & 0.035 & 1.29 \\
\hline 201 & $7.6 e-04$ & 10.1 & 0.023 & 1.90 & 162 & $4.7 e-03$ & 1.5 & 0.039 & 1.25 \\
\hline 211 & $1.6 \mathrm{e}-02$ & 7.9 & 0.079 & 1.78 & 202 & $1.3 e-04$ & 1.1 & 0.057 & 1.19 \\
\hline 222 & $8.2 e-05$ & 7.6 & 0.018 & 1.40 & 211 & $1.4 c-03$ & 0.8 & 0.029 & t.30 \\
\hline 231 & $2.0 e-02$ & 0.0 & 0.457 & 1.15 & 222 & $1.6 e-03$ & 0.6 & 0.026 & 1.56 \\
\hline \multirow[t]{2}{*}{241} & $2.5 e-02$ & 8.2 & 0.030 & 1.54 & 232 & $2.6 e-04$ & 0.8 & 0.031 & 1.23 \\
\hline & & & & & 250 & $3.4 e-03$ & 0.7 & 0.045 & 1.61 \\
\hline
\end{tabular}

'D Dimensionless curve-fitting parameter 
Appendix C.13 Results of unenriched tritium analysis for core samples from UE-3bl-U1.

\begin{tabular}{|c|c|c|c|c|c|}
\hline \multicolumn{4}{|c|}{$\begin{array}{c}\text { Borehole Depth Interval for } \\
\text { Core Samples }\end{array}$} & \multirow{3}{*}{$(\mathrm{pCi} / \mathrm{L})$} & \multirow[b]{3}{*}{$(+/-)$} \\
\hline from & to & from & to & & \\
\hline \multicolumn{2}{|c|}{ (m) } & \multicolumn{2}{|c|}{ (ft) } & & \\
\hline 3.9 & 4.0 & 12.75 & 13.00 & 849 & 245 \\
\hline 6.2 & 6.3 & 20.25 & 20.50 & 745 & 470 \\
\hline 12.2 & 12.3 & 40.00 & 40.25 & 420 & 458 \\
\hline 18.4 & 18.5 & 60.25 & 60.50 & $<350$ & \\
\hline 27.5 & 27.6 & 90.25 & 90.50 & $<350$ & \\
\hline 33.5 & 33.6 & 110.00 & 110.25 & $<350$ & \\
\hline 39.6 & 39.7 & 130.00 & 130.25 & $<350$ & \\
\hline 48.8 & 48.9 & 160.00 & 160.25 & 459 & 462 \\
\hline 61.0 & $61 . i$ & 200.25 & 200.50 & 417 & 430 \\
\hline 70.1 & 70.2 & 230.00 & 230.25 & $<350$ & \\
\hline
\end{tabular}

${ }^{1}$ Samples were archive core segments that were analyzed after the tritium analyses for the drill cuttings from UE-3b1-D1 showed concentrations above the dectection limit of $350 \mathrm{pCi} / \mathrm{L}$. 


\section{U3ax/bl Exploratory Boreholes}

Appendix D

Gyroscopic Survey Data 


\title{
U3ax/bl Exploratory Boreholes
}

\author{
Appendix D \\ Directional Survey Data
}

D.1 Gyroscopic Directional Survey by Minimum Curvature for UE-3bl-D1 on August 23, 1994

D.1 Gyroscopic Directional Survey by Minimum Curvature for UE-3bl-U1 on August 23, 1994 


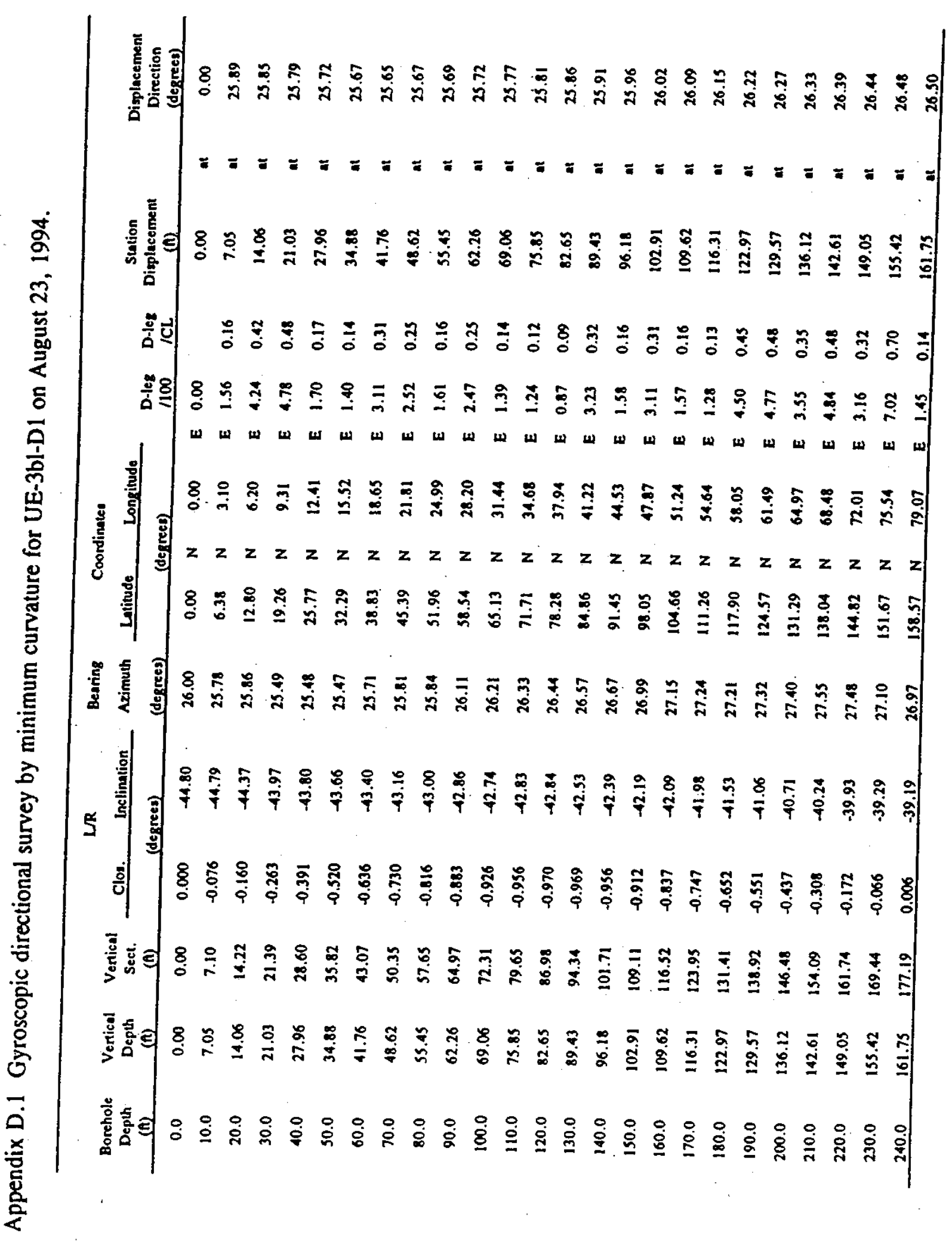




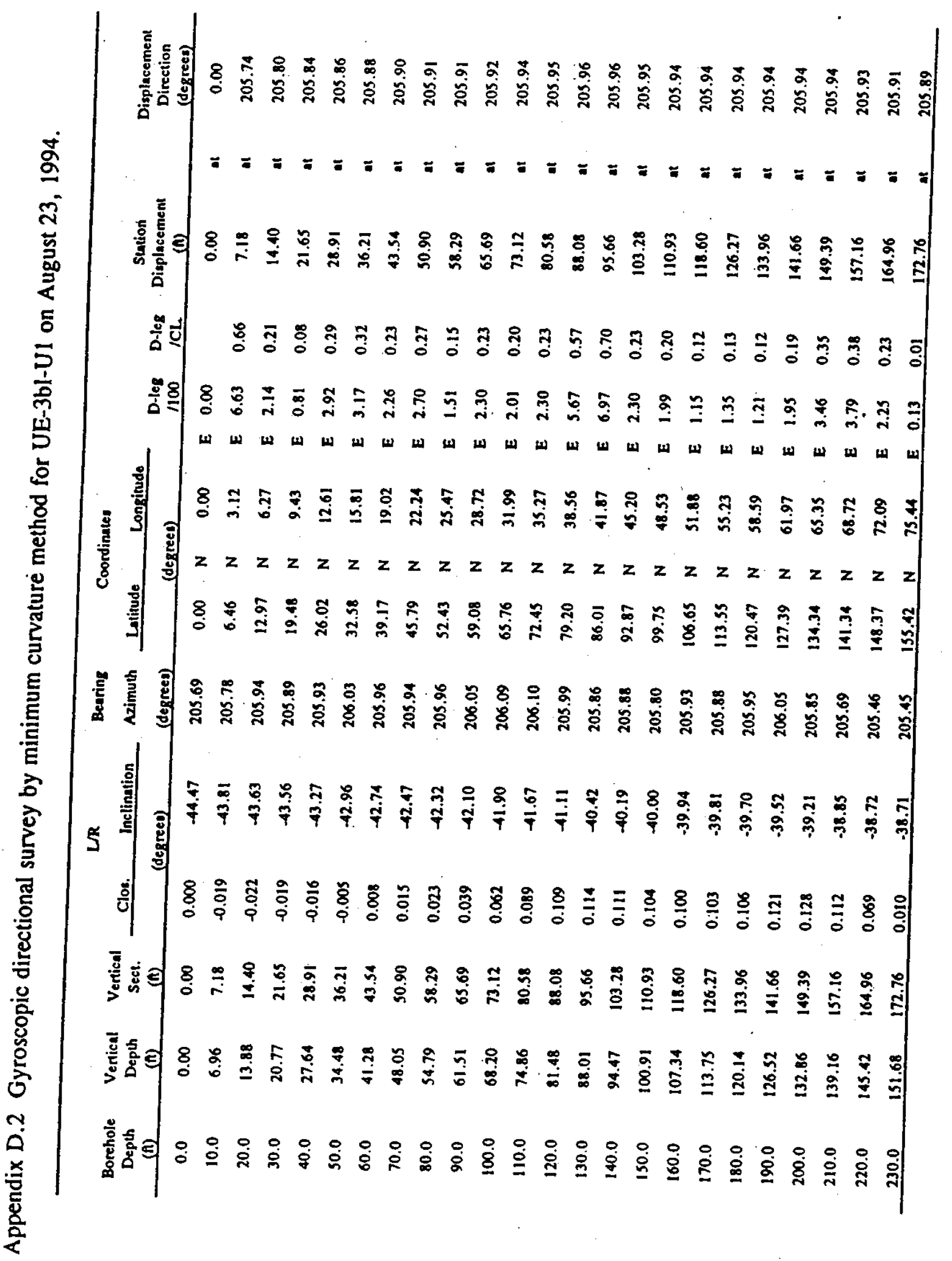




\section{Distribution List}

\section{U. S. Department of Energy}

\section{Copies}

Jhon Carilli

2

Waste Management Division

U.S. Department of Energy

National Nuclear Security Administration

Nevada Site Office

P.O. Box 98518, M/S 505

Las Vegas, NV 89193-8518

B. M. Crowe

Apogen Technologies

U.S. Department of Energy

National Nuclear Security Administration

Nevada Site Office

P.O. Box 98518, M/S 505

Las Vegas, NV 89193-8518

U.S. Department of Energy

National Nuclear Security Administration

1 (uncontrolled)

Nevada Site Office

Technical Library

P.O. Box 98518, M/S 505

Las Vegas, NV 89193-8518

U.S. Department of Energy

National Nuclear Security Administration

2 (electronic, uncontrolled)

Nevada Site Office

Public Reading Facility

c/o Nuclear Testing Archive

P.O. Box 98518, M/S 400

Las Vegas, NV 89193-8518

U.S. Department of Energy

Office of Scientific and Technical Information

1 (electronic, uncontrolled)

P.O. Box 62

Oak Ridge, Tennessee 37831-0062

\section{Bechtel Nevada}

Max Dolenc

Bechtel Nevada

P.O. Box 98521, M/S NSF080

Las Vegas, NV 89193-8521 


\section{Distribution List (continued)}

\section{Copies}

Environmental Management Library

Bechtel Nevada

P.O. Box 98521, M/S NLV094

Las Vegas, NV 89193-8521

Steve Nacht

Bechtel Nevada

P.O. Box 98521, M/S NSF083

Las Vegas, NV 89193-8521

Stuart Rawlinson

Bechtel Nevada

P.O. Box 98521, M/S NTS416

Las Vegas, NV 89193-8521

Dan Tobiason

Bechtel Nevada

P.O. Box 98521, M/S NTS416

Las Vegas, NV 89193-8521 